UNIVERSIDADE DE SÃO PAULO

FACULDADE DE EDUCAÇÃO

CRISTIANE BIBIANO SILVA

A PARTICIPAÇÃO DE MULHERES NO CONSELHO GESTOR DE UM CENTRO EDUCACIONAL UNIFICADO DA CIDADE DE SÃO PAULO:

MOTIVAÇÕES, EXPERIÊNCIAS E APRENDIZADOS 
CRISTIANE BIBIANO SILVA

\section{A PARTICIPAÇÃO DE MULHERES NO CONSELHO GESTOR DE UM CENTRO EDUCACIONAL UNIFICADO DA CIDADE DE SÃO PAULO: MOTIVAÇÕES, EXPERIÊNCIAS E APRENDIZADOS}

Dissertação apresentada ao Programa de Pós-Graduação em Educação da Faculdade de Educação da Universidade de São Paulo (Feusp), como requisito parcial para obtenção do título de Mestra em Educação.

Área de concentração: Educação e Ciências Sociais: desigualdades e diferenças

Orientadora: Prof $^{\mathrm{a}}$ Dr $^{\mathrm{a}}$ Cláudia Pereira Vianna 
Autorizo a reprodução e divulgação total ou parcial deste trabalho, por qualquer meio convencional ou eletrônico, para fins de estudo e pesquisa, desde que citada a fonte.

Silva, Cristiane Bibiano

B586p A participação de mulheres no Conselho Gestor de um Centro de Educação Unificado da cidade de São Paulo / Cristiane Bibiano Silva; orientadora Cláudia Pereira Vianna. -- São Paulo, 2020.

$226 \mathrm{p}$.

Dissertação (Mestrado - Programa de Pós-Graduação Educação e Ciências Sociais: Desigualdades e Diferenças) -- Faculdade de Educação, Universidade de São Paulo, 2020.

1. Educação. 2. Conselho Gestor. 3. Centro Educacional Unificado. 4. Mulheres. 5. Participação. I. Pereira Vianna, Cláudia, orient. II. Título. 
CRISTIANE BIBIANO SILVA

\section{A PARTICIPAÇÃO DE MULHERES NO CONSELHO GESTOR DE UM CENTRO EDUCACIONAL UNIFICADO DA CIDADE DE SÃO PAULO: MOTIVAÇÕES, EXPERIÊNCIAS E APRENDIZADOS}

Aprovada em:

\section{Banca examinadora}

Prof $^{\mathrm{a}} \mathrm{Dr}^{\mathrm{a}}$ Cláudia Pereira Vianna (orientadora)

Instituição: FE-USP

Assinatura

Prof $^{\mathrm{a}} \mathrm{Dr}^{\mathrm{a}}$ Teise Garcia Guaranha de Oliveira Instituição: FFCLRP - USP

Assinatura:

Prof $^{a} \operatorname{Dr}^{a}$ Maria Cristina Cavaleiro Instituição: UENP

Assinatura: 



\section{AGRADECIMENTOS}

Registro meu agradecimento àqueles que de alguma forma contribuíram para a concretização deste trabalho. Meus sinceros agradecimentos:

À Prof ${ }^{\mathrm{a}} \mathrm{Dr}^{\mathrm{a}}$ Cláudia Pereira Vianna, minha orientadora, pela confiança depositada em mim, pela acolhida generosa das ideias, paciência e dedicação. Foi um privilégio ter sido sua orientanda. Sem seu apoio, este trabalho não seria possível.

A toda minha família querida, em especial ao meu pai José Bibiano Silva, que me ensinou o valor da educação, por seu apoio incondicional, e à minha mãe Eloisa Helena Silva, que não só me ensinou a ler como também compreendeu minha ausência durante essa empreitada. Agradeço a eles por sempre respeitarem todas as minhas decisões e me apoiarem em todos os momentos.

À Karina, minha gêmea querida e amiga, por fazer parte da minha história, que desde sempre esteve na torcida, e por ter traduzido os trechos deste trabalho para o espanhol. Aos meus irmãos Valdir e Cláudio.

A todas as mulheres fortes da minha família, que servem e me serviram de inspiração e que de alguma forma estão representadas nas mulheres investigadas na pesquisa, especialmente à única avó que pude conhecer, Lucilda (in memoriam), e a minha tia-avó Dirce (in memoriam), que partiu recentemente.

Aos/às meus/minhas sobrinhos/as queridos/as: Gabriel, Beatriz, Silas, Paulo e Lídia.

Aos/às meus/minhas primos/as, em especial à Gabriela e à Carol pelas raras vezes que me foram companhia quando me ausentava da frente do computador. Agradeço à Patricinha pela atenção em me ouvir no momento de ansiedade.

Aos colegas e amigos do Dieese, do qual tive a oportunidade de trabalhar por mais de dez anos: Angela, Ademir, Ibarra, Patrícia, Vinícius, Joana, Fernando, Laender, Leonardo, Rodrigo, Renata, Marcos, Samira, Ângela, André, Tiago, Flávia, Marianna, Nádia, Silvanira, Lilica, Valéria, Karan, Ana Georgina, Rodrigo, Laércio, Odaci, Eliana, Aline, Camila, Victor, Sirlei, Celi, Laura, Luís, Juliana e Daniel, e a tantos outros que não cabem aqui, mas estão no coração. Agradeço especialmente ao querido amigo Pedro Neto pelo estímulo e orientação "informal" durante os anos de trabalho juntos. Agradeço à minha amiga Stênia, pelo companheirismo e 'ombro amigo' nos momentos mais difíceis. Obrigada ao amigo Guilherme, que durante as conversas do almoço me incentivou a prestar o mestrado. 
Às mulheres representantes do movimento sindical de trabalhadoras que conheci no curso de lideranças femininas, em 2017, no Dieese. Obrigada pelas ricas contribuições compartilhadas que serviram de referência para a pesquisa. Agradecimento à Maysa, que nas conversas ajudou a enriquecer o trabalho.

Às/aos colegas do grupo de Estudos de Educação, Gênero e Cultura Sexual (Edges) da Faculdade de Educação da Universidade de São Paulo que me deram todo o apoio ao longo desse mestrado e pela leitura cuidadosa do meu projeto: Cláudia Vianna, Carol Alvarenga, Thaís Gava, Thaís Pimentel, Alexandre Bortolini, Joanna, Mônica, Raquel, Natália, Hamilton, Keila, Alanis e à querida Bete (in memoriam) que partiu cedo. Sou especialmente grata à Edna pela ajuda na fase exploratória do trabalho de campo, com o repasse do contato da DRE e ao Paulinho, pelo trabalho minucioso de formatação do word na reta final do mestrado.

Às/aos colegas pelo convívio, conversas e debates nas aulas do mestrado, em especial: Adriana Depiere, Ivi Belmonte, José Salinas, Aida Binze, Adriano Souza, Maria de Fátima Vieira, Maria da Conceição, Thaís, Alê e Mônica.

Às/aos minhas/meus queridas/os amigas/os de longa data que me apoiaram e compreenderam minha ausência nesse percurso, obrigada pela força: Marina, Márcio, Ana Carolina, Marcela, Juliana, Thais e Renata. À Aline, mesmo longe, esteve presente. E a todos/as os/as demais, pela torcida e apoio mesmo que pelas redes sociais.

Aos/às companheiros/as de luta por um mundo mais igual, em especial pela atenção de Willian e à solicitude de Caio em relatar sua experiência na gestão do CEU.

Aos/às professores/as e colegas da Pós-Graduação do IFSP do Câmpus Pirituba, que estiveram comigo no semestre final da dissertação: Prof. Dr. Vagner Luís da Silva, Prof. M.e Danilo Amorim de Souza, Prof ${ }^{\mathrm{a}}$. Dr ${ }^{\mathrm{a}}$. Vanessa Regina Ferreira da Silva, Prof ${ }^{\mathrm{a}}$. Ana Paula Bulgarelli, Prof ${ }^{a}$. Dr ${ }^{\mathrm{a}}$. Ana Carolina Vila Ramos dos Santos e Prof. Dr. Renato Marcon Pugliese. Agradeço especialmente à $\operatorname{Prof}^{a}$ Dr $^{\mathrm{a}}$. Teresa Helena Buscato Martins por me ajudar nos trâmites da participação do $4^{\mathrm{a}}$ Conpog onde apresentei a pesquisa. Já que estou fazendo menção a esse congresso, que ocorreu em novembro de 2019, aproveito para agradecer à Pró-Reitoria de Pesquisa e Pós-graduação do Instituto Federal de Educação, Ciência e Tecnologia de São Paulo pelo auxílio financeiro para a participação no evento e a todos os que participaram da apresentação e somaram para o aperfeiçoamento da minha dissertação. Um agradecimento especial às colegas de classe do IFSP, Dagmar por me manter atualizada dos prazos das avaliações de final de semestre e à Anna Carolina pelas traduções do resumo em inglês.

À Prof ${ }^{\mathrm{a}} \mathrm{Dr}^{\mathrm{a}}$ Marília Carvalho, por gentilmente ter aceitado o convite de integrar a banca examinadora de qualificação e, agora, como suplente da banca de dissertação. Obrigada pelas 
ricas contribuições para este estudo ao apontar direções possíveis por meio da escuta minuciosa das entrevistadas.

À Prof ${ }^{a} \operatorname{Dr}^{\mathrm{a}}$ Teise Garcia Guaranha de Oliveira, por aceitar fazer parte da banca examinadora de qualificação e, agora, da dissertação. As ricas contribuições colaboraram enormemente para o amadurecimento do meu trabalho.

À Prof ${ }^{\mathrm{a}}$ Dr $^{\mathrm{a}}$ Maria Cristina Cavaleiro, por aceitar fazer parte da banca examinadora.

À Prof ${ }^{a} \operatorname{Dr}^{\mathrm{a}}$ Theresa Maria de Freitas Adrião e à Prof ${ }^{\mathrm{a}} \operatorname{Dr}^{\mathrm{a}}$ Tânia Suely Antonelli Marcelino Brabo, por aceitarem o convite de suplente da banca examinadora.

Agradeço novamente à $\operatorname{Prof}^{\mathrm{a}} \operatorname{Dr}^{\mathrm{a}}$ Cláudia Pereira Vianna, por fazer parte da banca examinadora de qualificação e da banca examinadora da dissertação. Obrigada por me guiar respeitosamente durante o árduo caminho da pesquisa.

A todos/as os/as professores e professoras com as quais tive a chance de aprender durante o meu percurso acadêmico. Agradeço conhecimento compartilhado nas disciplinas que cursei durante o mestrado com os Profs. Drs. Romualdo Portela, Marília Carvalho, Rúrion Melo e Gustavo Venturi.

Aos/às funcionários/as da Secretaria da Pós-Graduação, da Secretaria do EDA e da Biblioteca da Faculdade de Educação da Universidade de São Paulo pela presteza e cortesia no atendimento.

À Diretoria Regional de Educação, da Secretaria Municipal de Educação de São Paulo, por conceder autorização de realização da pesquisa acadêmica.

A todos os profissionais dos CEUs, pela simpatia e receptividade com que me receberam na realização da pesquisa de campo, em especial à atual gestora do CEU escolhido pela atenção com que me acolheu e compartilhou comigo sua história, enriquecendo a pesquisa. Muito obrigada!

Às mulheres conselheiras protagonistas da luta diária na cidade de São Paulo e que ao me concederam as entrevistas, confiaram em compartilhar comigo suas histórias, visões de mundo, opiniões e esperanças, sem as quais este trabalho não se realizaria. Toda a experiência que obtive ao longo do trabalho de campo contribuiu para ser uma melhor pesquisadora e, acredito, a uma pessoa melhor. Espero que este trabalho possa ajudar de alguma forma a melhorar as condições educacionais e sociais da comunidade.

E, finalmente, agradeço a Deus, pela saúde, força e todo amor que me ajudou a me manter firme na luta por acreditar em uma sociedade mais justa, igualitária e democrática. 



\section{RESUMO}

O objetivo desta pesquisa de mestrado é compreender as motivações, as experiências e os aprendizados derivados da participação de mulheres, no Conselho Gestor de um Centro Educacional Unificado (CEU) da cidade de São Paulo. A intenção foi apreender como essa participação influencia a vida dessas mulheres que vivem no entorno do equipamento público educacional na periferia e as consequências da participação no Conselho Gestor de escola em suas vidas como mulheres, mães e integrantes do bairro. Trata-se de uma pesquisa de natureza qualitativa, que dialoga com estudos sobre gestão escolar sob a ótica de gênero. Para esta pesquisa, foram entrevistadas cinco mulheres. Os resultados da investigação mostram um empoderamento dessas mulheres que integram o Conselho Gestor do CEU em análise. Tratase de um empoderamento que corresponde à dimensão educativa da participação dessas mulheres em espaços para além do universo doméstico, o que envolve motivações, experiências e aprendizados para o debate de pautas múltiplas que ampliam a visão e as expectativas dessas mulheres.

Palavras-chave: Educação. Conselho Gestor. Centro Educacional Unificado. Mulheres. Participação. 


\begin{abstract}
The objective of this Master's Degree research is to understand the motivations, experiences and learning derived from the participation of women in the Management Council of a Unified Educational Center (CEU) in the city of São Paulo. The intention was to apprehend how this participation influences the lives of these women, who live around the public educational facilities in the poor suburbs and the consequences of participating in the School Management Council in their lives as women, as mothers, and as members of the neighborhood community. This is a qualitative research, which dialogues with studies on school management from a gender perspective. For this research, five women were interviewed. The results of the investigation show empowerment of these women who participate of the Management Council of the CEU under analysis. It is an empowerment that corresponds to the educational dimension of the participation of these women in environments out of the domestic universe, which involves motivations, experiences and learning for the debate of multiple agendas that expand the vision and expectations of these women.
\end{abstract}

Keywords: Education. Management Board. Unified Educational Center. Women. Participation. 


\section{LISTA DE SIGLAS}

ACMS - Associação dos Condomínios do Morumbi Sul

AEL - Áreas de Estruturação Local

Apeoesp - Associação de Professores do Ensino Oficial do Estado de São Paulo

APM - Associação de Pais e Mestres

Apmsuac - Associação de Pais e Mestres, Servidores, Usuários e Amigos dos Centros Educacionais Unificados

BA - Bahia

BPC - Benefício de Prestação Continuada

CAE - Conselho de Alimentação Escolar

CCA - Centro para Criança e Adolescente

CDC - Clube da Comunidade

CDHU - Companhia de Desenvolvimento Habitacional e Urbano do Estado de São Paulo

CEIs - Centros de Educação Infantil

Cenenpec - Centro de Estudos e Pesquisas em Educação, Cultura e Ação Comunitária

CET - Companhia de Engenharia e Tráfego

CEUs - Centros Educacionais Unificados

CGs - Conselhos Gestores

CID - Coordenadoria de Inclusão Digital

CIPA - Comissão Interna de Prevenção de Acidentes

CME - Conselho Municipal de Educação

Codefat - Conselho Deliberativo do FAT

Conpog - Congresso de Pós-Graduação do IFSP

Cras - Centro de Referência de Assistência Social

Creas - Centro de Referência Especializado em Assistência Social

Crece - Conselho de Representantes do Conselho de Escola

DEM - Democratas

Dieese - Departamento Intersindical de Estatística e Estudos Socioeconômicos

DRE - Diretoria Regional de Educação da Secretaria Municipal de Educação de São Paulo

EC - Emendas Constitucionais

EDA - Departamento de Administração Escolar e Economia da Educação

Edges - Estudos de Gênero, Educação e Cultura Sexual

EEs - Escolas Estaduais

EJA - Educação de Jovens e Adultos

Emefs - Escolas Municipais de Ensino Fundamental

Emeis - Escolas Municipais de Educação Infantil

ES - Ensino Superior

Etecs - Escolas Técnicas Estaduais

Fespsp - Fundação Escola de Sociologia e Política de São Paulo

Feusp - Faculdade de Educação da Universidade de São Paulo

FIA - Fundação Instituto de Administração da Universidade de São Paulo

FFCLRP USP - Faculdade de Filosofia, Ciências e Letras de Ribeirão Preto da Universidade de São Paulo

FFLCH - Faculdade de Filosofia Letras e Ciências Humanas

IDH - Índice de Desenvolvimento Humano

IFSP - Instituto Federal de Educação, Ciência e Tecnologia de São Paulo

INSS - Instituto Nacional do Seguro Social 
IPF - Instituto Paulo Freire

IVS - Índice de Vulnerabilidade Social

LDB - Lei de Diretrizes e Bases da Educação Nacional

LGBT - Lésbicas, Gays, Bissexuais, Travestis, Transexuais ou Transgêneros

MDB - Movimento Democrático Brasileiro

Minc - Ministério da Cultura

MTb - Ministério do Trabalho

MTE - Ministério do Trabalho e Emprego

NPI - Núcleo de Produção e Informação

ONU - Organização das Nações Unidas

OP - Orçamento Participativo

PDE - Plano Diretor Estratégico

PED - Pesquisa de Emprego e Desemprego

PIU - Projetos de Intervenção Urbana

PNPM - Plano Nacional de Políticas para as Mulheres

PPP - Projetos Políticos-Pedagógicos

Pronatec - Programa Nacional de Acesso ao Ensino Técnico e Emprego

PSB - Partido Socialista Brasileiro

PSD - Partido Social Democrático

PSDB - Partido da Social Democracia Brasileira

PT - Partido dos Trabalhadores

PTB - Partido Trabalhista Brasileiro

PTDA - Plano Anual de Transparência Ativa e Dados Abertos

RE - Regimentos Escolares

RMSP - Região Metropolitana de São Paulo

Sacc - Sistema de Acompanhamento de Acordos e Convenções Coletivas

SDTS - Secretaria do Desenvolvimento, Trabalho e Solidariedade

Sesc - Serviço Social do Comércio

Siconv - Sistema de Gestão de Convênios e Contratos de Repasse

Siurb - Secretaria de Infraestrutura Urbana e Obras

SMC - Secretaria Municipal de Cultura

SMDU - Secretaria Municipal de Desenvolvimento Urbano

SME - Secretaria Municipal de Educação

SMTrab - Secretaria Municipal do Trabalho

SP - São Paulo

SPM - Secretaria de Políticas para as Mulheres

SPPE - Secretaria de Políticas Públicas de Emprego

Suprof - Superintendência de Educação Profissional da Bahia

SUS - Sistema Único de Saúde

TSE - Tribunal Superior Eleitoral

TV - Televisão

UAB - Universidade Aberta do Brasil

UBS - Unidade Básica de Saúde

Uenp - Universidade Estadual do Norte do Paraná

UniCEU - Rede das Universidades dos Centros Educacionais Unificados

Univesp - Universidade Virtual do Estado de São Paulo

USP - Universidade de São Paulo

UTI - Unidade de Tratamento Intensivo

VAI - Programa para a Valorização de Iniciativas Culturais

WEPs - Women's Principles Empowerment - Princípios de Empoderamento das Mulheres 
À Marielle Franco

(in memoriam) 



\section{SUMÁRIO}

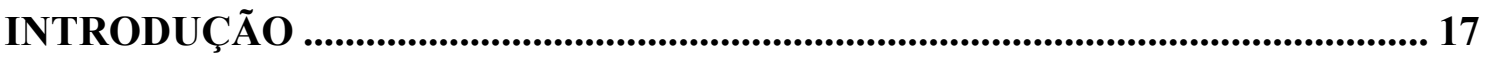

1 A CRIAÇÃO DOS CEUS E SEUS CONSELHOS GESTORES ......................... 23

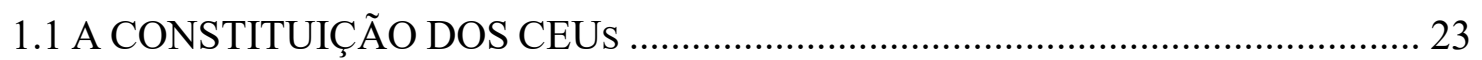

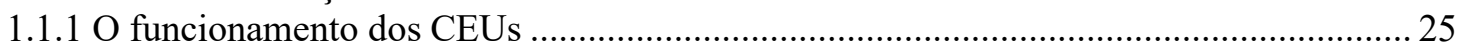

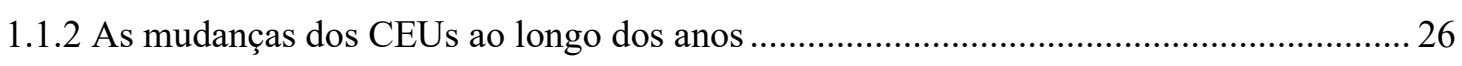

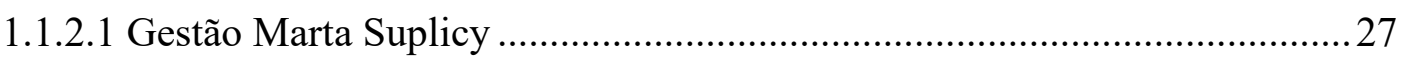

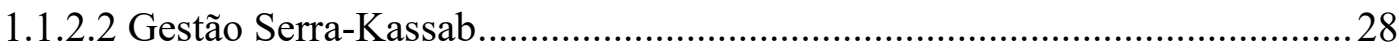

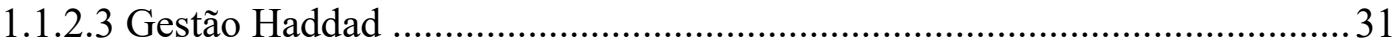

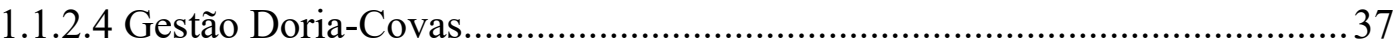

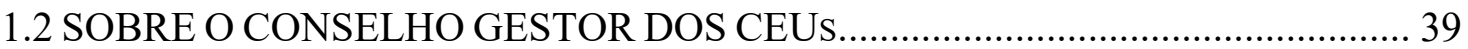

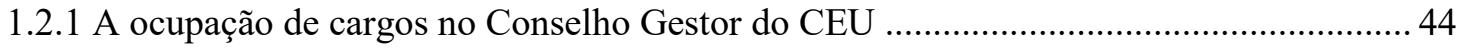

1.2.2 As mudanças nas esferas participativas dos CEUs .......................................................... 45

2 OS CAMINHOS DA PESQUISA.......................................................................... 49

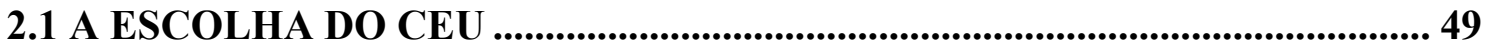

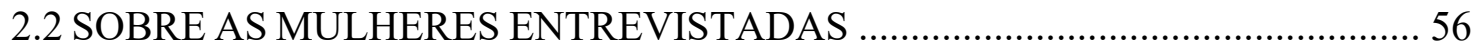

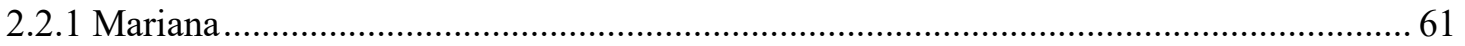

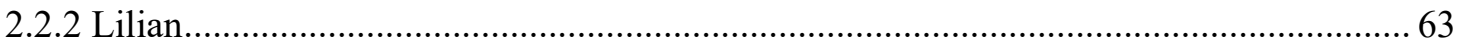

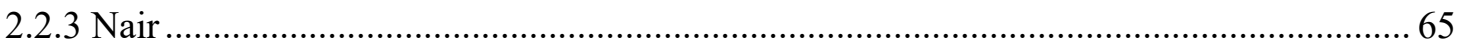

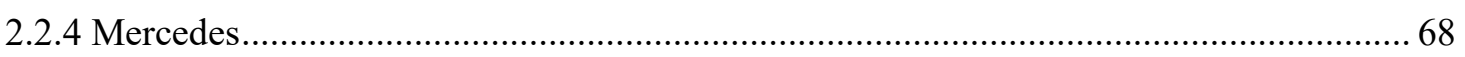

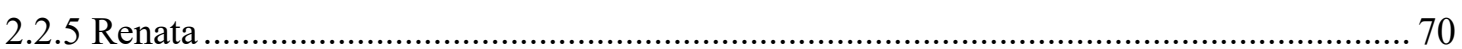

3 AS MULHERES NO CONSELHO GESTOR DO CEU: MOTIVAÇÕES, EXPERIÊNCIAS E APRENDIZADOS ................................................................... 73

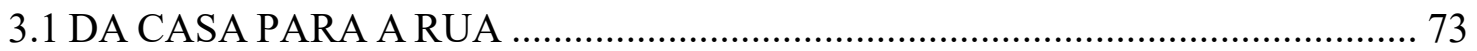

3.1.1 Porque realmente o trabalho doméstico da mulher nunca foi visto como um trabalho ... 75

3.1.2 Resolvi estudar e fui estudando, aí sofri um problema de saúde que me atrapalhava de

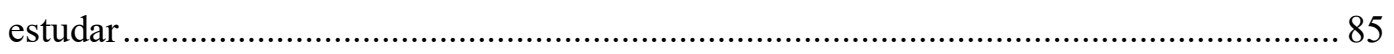

3.1.3 Ainda faço um trabalho que a minha filha trabalha numa fábrica de pulseiras ............... 88

3.1.4 Sempre gostei muito de participar, participação ativa, de ajudar, também, sabe? ........... 94

3.2 A RUA É O CÉU, MAS É MINHA CASA TAMBÉM: CHEGADA AO CONSELHO

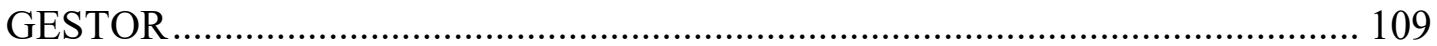

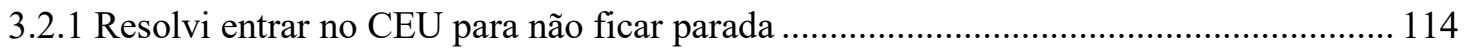

3.2.2 Uma pessoa de trinta anos, ela tem que estar correndo atrás da vida ........................... 118

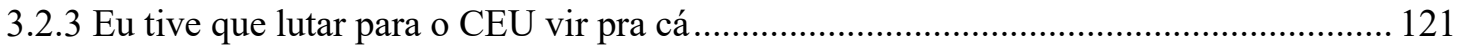

3.2.4 O que é participar do Conselho Gestor, para que serve e para que deveria servir......... 123

3.3 A PARTICIPAÇÃO NO CONSELHO GESTOR DO CEU: CONTRIBUIÇÕES E

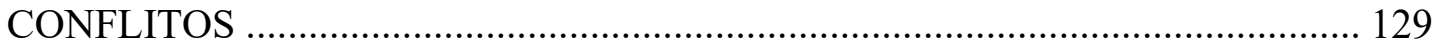

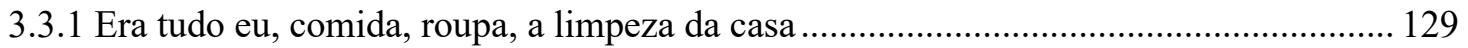


3.3.2 De vez em quando Deus me tira a poesia, olho pedra, vejo pedra mesmo

3.3.3 Desde que os portugueses chegaram aqui, a gente sempre foi mandado 139

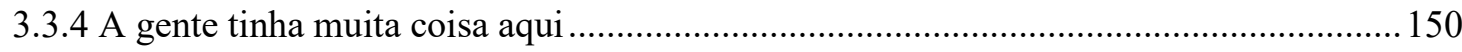

3.3.5 Sou usuária, sou da comunidade e eu sou fiscal do povo mesmo .................................. 152

3.3.6 Mulher é que é boa para fiscalizar, para falar, para ter boca para falar .......................... 157

3.3.7 Dificuldades de estabelecer necessidades conjuntas: estou um pouco sem poesia......... 161

3.3.8 Sobre o uso do CEU como espaço cultural e como espaço educacional: como educador, ele tem que olhar no entorno

3.4 A PARTICIPAÇÃO NO CONSELHO GESTOR DO CEU: EMPODERAMENTOS

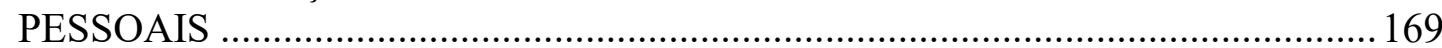

3.4.1 Começam a cuidar mais de si - Eu acho que eu sou uma pessoa ativa .......................... 170

3.4.2 Voltam a estudar - Vou voltar a estudar, vou me formar; vou dar isso para mim.......... 174

3.4.3 Circulam no próprio bairro e fora dele - A gente saía muito sabe, sempre tinha passeio 178

3.4.4 Conselho Gestor como argumento para sair de casa, fazer amizades - Uma das maneiras de eu diminuir o cigarro é estando aqui no CEU ............................................................ 185

3.4.5 Negociação e participação - Mas sempre tudo sobra para a mulher mesmo ................... 187

3.4.6 CEU e CG como reconhecimento pessoal e empoderamento das mulheres - "Lá são os

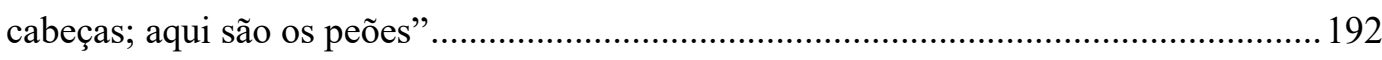

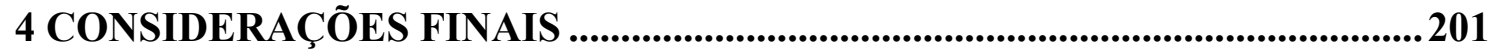

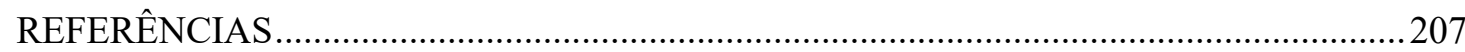

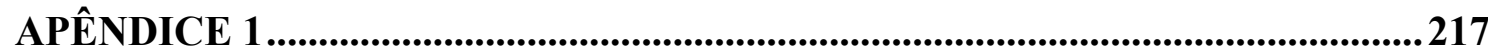

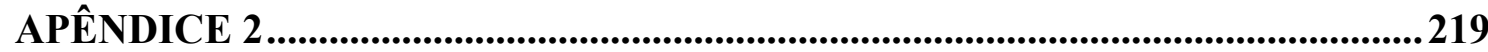

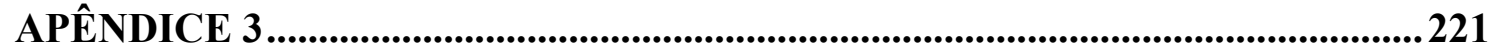

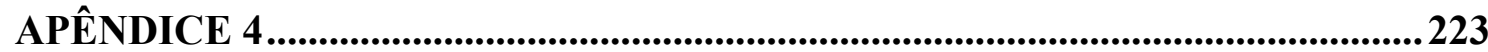

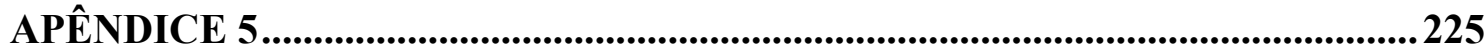




\section{INTRODUÇÃO}

Ingressei na Universidade de São Paulo, no curso de Letras, da Faculdade de Filosofia Letras e Ciências Humanas, no ano de 2003, mas cursei somente o ano básico. Ainda em 2003, em processo seletivo de transferência interna, ingressei no curso de Ciências Sociais da mesma Faculdade, no ano seguinte.

Durante o primeiro ano da graduação em Ciências Sociais, na Faculdade de Filosofia Letras e Ciências Humanas (FFLCH), da Universidade de São Paulo (USP), iniciei estágio na Secretaria do Desenvolvimento, Trabalho e Solidariedade (SDTS) da Prefeitura de São Paulo e lá permaneci até 2006. Foi um estágio que abrangeu o final da gestão da prefeita Marta Suplicy (2001-2005), do Partido dos Trabalhadores (PT) e o início da gestão do prefeito José Serra e Gilberto Kassab (2005-2008), do Partido da Social Democracia Brasileira (PSDB), porém com nova denominação da secretaria para SMTrab (Secretaria Municipal do Trabalho).

Depois, no ano de 2007, ainda vinculada à Graduação, iniciei estágio na área de Pesquisas Sindicais, no Departamento Intersindical de Estatística e Estudos Socioeconômicos (Dieese), onde permaneci por dois anos no trabalho de catalogação de cláusulas de acordos e convenções coletivas para o banco de dados interno denominado Sistema de Acompanhamento de Acordos e Convenções Coletivas (Sacc). Em 2009, fui contratada, por tempo determinado, até 2010, na função de auxiliar técnica, e passei a fazer parte da equipe de Coordenação de Estudos e Desenvolvimento do Dieese, na área dos Observatórios do Trabalho. Ainda em 2010, concluí o bacharelado em Ciências Sociais pela Universidade de São Paulo e fui promovida ao cargo de Técnica I, no trabalho de sistematização, análise de indicadores socioeconômicos e na produção de anuários estatísticos, na área do Núcleo de Produção e Informação (NPI) do Dieese.

Ainda, em 2010, assumi a responsabilidade técnica, no Dieese, de participar do desenvolvimento e produção do periódico Anuário das Mulheres Brasileiras 2011, Convênio 072/2010 denominado "As mulheres no mercado de trabalho brasileiro: informações qualitativas e quantitativas" (DIEESE, 2011), em parceria do Dieese com a Secretaria de Políticas das Mulheres (SPM), publicação que reúne síntese de dados e estatísticas sobre a temática de gênero, composto por temas sobre demografia e família, trabalho e autonomia da mulher, trabalho doméstico, educação, saúde, espaços de poder e violência. O objetivo da publicação era subsidiar e orientar a aplicação das políticas de erradicação das desigualdades de gênero, sobretudo ao movimento sindical, e isso me aproximou das temáticas de gênero e 
políticas públicas, principalmente em um momento em que o Brasil avançava sua demanda por informações estatísticas com a finalidade de implementação de programas sociais (JANNUZZI, 2009). Em virtude do trabalho de assessoria técnica do Dieese, a publicação me possibilitou a participação em outros espaços de discussões sobre gênero e mercado de trabalho, com vistas a divulgar o Anuário. Uma das minhas atividades foi a Audiência Pública (PEDRO, 2011), organizada pela Comissão de Educação e Cultura, na Assembleia Legislativa do Estado de São Paulo, além da participação de mesa redonda sobre "Inclusão de grupos vulneráveis no mercado de trabalho", atividade organizada pela Fundação Escola de Sociologia e Política de São Paulo (FESPSP), realizado pela Secretaria do Emprego e Relações de Trabalho do Governo do Estado de São Paulo.

Em 2012, obtive o título de Licenciada em Ciências Sociais pela Faculdade de Educação da mesma Universidade e, concomitante ao trabalho no Dieese, inicio participação no projeto de Educomunicação "Click, um olhar curioso sobre o mundo", do Programa VAI (Valorização de Iniciativas Culturais), promovido pela Secretaria Municipal da Cultura da Prefeitura de São Paulo, até o término de 2014. O objetivo do projeto, com os jovens da comunidade de Pirituba, era a manutenção de um canal de notícias online e uma publicação mensal. A experiência de participação foi relevante, sobretudo porque me aproximou da realidade do território onde resido e de conhecimento de sua história, que até então desconhecia.

Em 2012, junto com estudantes universitários, principalmente da USP, participei da campanha eleitoral para a prefeitura do Fernando Haddad, do Partido dos Trabalhadores (PT), que naquele ano disputava cargo de prefeito com José Serra, do PSDB. Com Haddad no executivo municipal de São Paulo, no período de 2013 a 2016, pude me aproximar de espaços de participação política, tanto como representante do movimento de cultura do bairro quanto como militante.

Enquanto isso, entre 2012 a 2015, no Dieese, fui designada a compor equipe no âmbito do Projeto: Subsídios para o fortalecimento, consolidação e promoção da qualidade da educação profissional do Estado da Bahia, Convênio nº 495/2012, realizado com o Dieese e a Superintendência de Educação Profissional da Bahia - Suprof e da Secretaria da Educação do Estado da Bahia. Além da participação na produção de publicações (DIEESE, 2012) e anuários estatísticos (DIEESE, 2014), voltados à temática da educação profissional (DIEESE, 2011b), previsto no Convênio, o projeto permitiu o desenvolvimento do Produto 2 sobre a "Promoção do diálogo social e mapeamento da oferta e demanda de educação profissional nos territórios de identidade" contido no Subprojeto II "Desenvolvimento de indicadores para avaliação e planejamento da oferta e demanda da educação profissional da Bahia". O trabalho tinha o 
objetivo de mapeamento das necessidades e demandas de Educação Profissional nos "Territórios de Identidade ${ }^{1}$ da Bahia do: Litoral Sul, Baixo Sul, Piemonte do Paraguaçu, Bacia do Jacuípe, Piemonte da Diamantina, Sertão Produtivo, Bacia do Paramirim, Itaparica e Metropolitana de Salvador.

A rica experiência de participação no Projeto de Educação Profissional da Bahia, além de ter agregado conhecimento de metodologias de pesquisa quantitativas e qualitativas, aproximou-me de outras realidades e da diversidade cultural do estado baiano. Nas atividades de diálogos sociais, conheci pessoas e características dos municípios de Ilhéus, Valença e Itaberaba, passando pelo sertão de Ipirá, Macaúbas, da cidade da energia eólica de Guanambi, cruzando por Jacobina até Paulo Afonso com suas quedas d'água, chegando ao polo industrial de Camaçari, já na Região Metropolitana de Salvador, no curto período de cinco meses, aproximadamente.

O trabalho no Convênio MTE/SPPE/Codefat $n^{\circ}$ 003/2014 - Dieese/Siconv $n^{\circ}$ 811485/2014, celebrado, em 2014, pelo Departamento Intersindical de Estatística e Estudos Socioeconômicos (Dieese), com o Ministério do Trabalho (MTE²), denominado "Desenvolvimento de instrumentos e atualização dos indicadores de apoio à gestão de políticas públicas de emprego, trabalho e renda" me aproximou de espaços de Conselho de Emprego e Renda. Como a temática de gênero me instigava, foi no desenvolvimento de um dos produtos, denominado de Fortalecimento da gestão do Conhecimento do Sistema Público de Emprego, Trabalho e Renda, que pude perceber as dificuldades que as mulheres possuem ao participar de Conselhos de Emprego e Renda. Durante a atividade em Brasília, ficou-me claro que as características tipicamente masculinas estavam ligadas à desinibição e naturalidade com o uso da fala em microfone, entre os participantes homens, enquanto havia dificuldade de verbalização e de posicionamento das mulheres no espaço público. Notadamente, havia distinção na participação entre homens e mulheres. Em conversa informal com umas das conselheiras da região norte do país, ficou clara a existência de obstáculos por participar da atividade no Distrito Federal. O relato mostrava a preocupação da conselheira com a inabilidade do marido para com as atividades domésticas e no cuidado aos filhos menores, já que ela estava ausente de casa, além de sua obrigação de fotografar alguns momentos da atividade semanal em Brasília, para comprovar ao marido que estava no evento. A conversa com a conselheira e

\footnotetext{
${ }^{1}$ Considera-se Território de Identidade o agrupamento identitário municipal formado de acordo com critérios sociais, culturais, econômicos e geográficos, reconhecido pela sua população como espaço historicamente construído ao qual pertence, com identidade que amplia as possibilidades de coesão social e territorial, conforme decreto estadual do estado da Bahia $n^{\circ} 12.354$, de 25 de agosto de 2010

${ }^{2}$ Em 2015, a sigla do Ministério do Trabalho (MTE) mudou para MTb.
} 
as observações do evento serviram de inspiração para o projeto de mestrado, que seria construído somente em 2016.

Antes, porém, em 2014, ingressei novamente no curso de Letras da Universidade de São Paulo e por já ter concluído algumas disciplinas do ciclo básico em 2003, solicitei equivalência de disciplinas. Em 2015, concluí a disciplina no curso de Letras sobre Teorias de Texto Enunciação, Discurso e Texto (FLC0285), com a $\operatorname{Prof}^{\mathrm{a}} \operatorname{Dr}^{\mathrm{a}}$ Sheila Vieira de Camargo Grillo. No mesmo ano, cheguei a frequentar parcialmente a disciplina, do Departamento de Ciência Política da FFLCH, denominada de Métodos e Técnicas de Pesquisa em Ciência Política (FLP0406), sem concluí-la, tendo em vista a necessidade de cursar outra disciplina introdutória para o melhor aproveitamento.

No primeiro semestre de 2016, cursei, pela última vez uma disciplina na graduação, na Faculdade de Educação, da Universidade de São Paulo, ministrada pela $\operatorname{Prof}^{\mathrm{a}} \operatorname{Dr}^{\mathrm{a}}$ Cláudia Pereira Vianna, intitulada Relações de Gênero e Educação II: Escola e Relações de Gênero (EDA0663), tendo obtido 100\% de frequência e nota final de aprovação da disciplina de 9,0. No mesmo semestre, submeti meu projeto de mestrado para a seleção e fui aprovada, tendo ingressado no Programa de Pós-Graduação da Faculdade de Educação da Universidade de São Paulo em janeiro de 2017. Entre 2017 e o primeiro semestre de 2018, cursei as disciplinas obrigatórias do mestrado, no Departamento de Administração Escolar e Economia da Educação (EDA), Educação e Desigualdade (EDA 5059) e Relações de Gênero e Educação Escolar (EDA 5030). Na Faculdade de Filosofia, Letras e Ciências Humanas, cursei as disciplinas Feminismo e Teoria Crítica (Fls 6411), pelo Departamento de Ciência Política, e Moralidade e Interseccionalidade de Marcadores Sociais (Fls 5180), pelo Departamento de Sociologia da mesma Faculdade.

Após desligamento funcional do Dieese, em dezembro de 2018, ao mesmo tempo que me dedicava ao mestrado stricto sensu na USP, em junho de 2019, fui aprovada no processo seletivo para o curso de Pós-Graduação Lato Sensu em nível de Especialização em Humanidades - Educação, Política e Sociedade no Instituto Federal de Educação, Ciência e Tecnologia de São Paulo (IFSP), no câmpus São Paulo - Pirituba. O início das aulas ocorreu em agosto de 2019 com previsão de término das disciplinas das componentes curriculares cursadas para dezembro de 2020.

Toda a experiência profisssional e acadêmica serviu de inspiração para dialogar com a realidade de mulheres, agora com maior proximidade à área da educação. Por ter realizado toda minha educação formal no ensino público, assumi o compromisso de poder contribuir para a melhoria da educação pública brasileira, além de dar o retorno à sociedade dos anos como 
estudante do ensino público, tanto em unidades escolares de dependência administrativa municipal, estadual e, mais recentemente, no âmbito federal. O presente projeto pretende ser uma parte dessas contribuições. Assim, elaborei meu projeto de mestrado com o foco nas mulheres conselheiras de um Centro Educacional Unificado (CEU) com o objetivo de analisar como as desigualdades sociais e de gênero interferem na participação junto ao Conselho Gestor.

O objetivo, portanto, deste trabalho é compreender as experiências de participação de mulheres no Conselho Gestor de um Centro Educacional Unificado (CEU), da cidade de São Paulo, com destaque para como a participação influencia a vida das mulheres que vivem no entorno do equipamento público educacional, na periferia, e as consequências da participação no Conselho Gestor em suas vidas.

Este trabalho está organizado em três capítulos. O primeiro busca situar o histórico de constituição dos Centros Educacionais Unificados (CEUs), seu funcionamento e as mudanças pelas quais o projeto passou ao longo das gestões municipais na cidade de São Paulo. Apresento, ainda, como os Conselhos Gestores foram concebidos e a forma como ocorreu a ocupação de cargos.

No segundo capítulo, faço a apresentação dos procedimentos metodológicos da pesquisa, desde como foi feita a escolha do CEU selecionado, os primeiros contatos no Centro Educacional e com as conselheiras participantes. O capítulo ainda apresenta um breve perfil de cada conselheira entrevistada.

No terceiro e último capítulo, analiso os depoimentos das entrevistadas durante o trabalho de campo, as motivações que levam as mulheres conselheiras a saírem de casa para a participação na rua, antes de entrarem para o Conselho. Na segunda parte do capítulo, trago relatos de como as mulheres participam do espaço da "rua". A terceira parte compreende a apresentação dos embates resultantes da participação. No quarto item do capítulo, apresento os empoderamentos, resultado da participação no espaço do CEU.

Nas Considerações Finais, apresento as principais conclusões, retiradas dos relatos das conselheiras, que mostram como suas experiências converteram-se em empoderamentos. Os apêndices trazem o panorama dos CEUs, a síntese da infraestrutura existente em cada aparelho educacional e, também, o modelo do Termo de Consentimento Livre e Esclarecido, o modelo do Roteiro da Entrevista Individual e o modelo do Questionário Individual. 



\section{A CRIAÇÃO DOS CEUS E SEUS CONSELHOS GESTORES}

A educação é um ato de amor, por isso, um ato de coragem. Não pode temer o debate. A análise da realidade. Não pode fugir à discussão criadora, sob pena de ser uma farsa. - Paulo Freire

Neste capítulo busco oferecer uma breve síntese sobre como se deu a constituição do Centro Educacional Unificado (CEU), passando pelas principais mudanças implementadas pelas gestões do executivo municipal, que influenciaram sua organização e sua relação com a comunidade. A partir de um breve resgate histórico do surgimento dos Conselhos Gestores no país, procuro apontar alguns elementos teóricos que contribuem para o entendimento da participação nos Conselhos Gestores dos CEUs no município de São Paulo, seu funcionamento e gestão a partir das principais alterações regimentais relacionadas ao tema. Finalmente, após análise do CEU e do Conselho Gestor, dialogo com alguns elementos teóricos com vistas à análise da participação das mulheres no Conselho Gestor do CEU.

\subsection{A CONSTITUIÇÃO DOS CEUS}

Os Centros Educacionais Unificados (CEUs) começam a ser estruturados durante o governo do Partido dos Trabalhadores (PT), na cidade de São Paulo, no ano de 2001, quando a prefeita Marta Suplicy chega ao executivo municipal. Outras administrações petistas também implementaram o modelo dos CEUs, com a nomenclatura de Centros de Artes e Esportes Unificados em Salvador (BA) e Ribeirão Preto (SP), por exemplo. Para compreender o projeto de constituição dos CEUs, inaugurados na cidade de São Paulo, a partir de 2003, é pertinente a discussão em torno da concepção de educação e do modo de gestão petista (2001-2004) à frente da administração municipal em São Paulo. (RODRIGUES, 2018)

De acordo com Og Doria e Maria Aparecida Perez (2007), as ideias de Paulo Freire contribuíram para inspirar os Centros Educacionais Unificados, com a concepção de educação para a cidadania e a escola aberta, assim como os projetos de Parques Infantis, criados por Mario de Andrade, nos anos de 1930, tendo como inspiração as Escolas Parques, desenvolvidas pelo baiano Anísio Teixeira, na década de 1950, com a integração e convivência das pessoas em espaços públicos.

Quando assume a Secretaria Municipal de Educação, em 1989, no governo da prefeita Luiza Erundina, pelo Partido dos Trabalhadores (PT), o educador Paulo Freire propõe um modelo de escola pública “democrática, popular, rigorosa, séria, respeitadora e estimuladora da 
presença popular nos destinos da escola que se vá tornando cada vez mais uma escola alegre." (DORIA; PEREZ, 2007, p. 99)

O conceito de Cidade Educadora, que implica uma concepção educacional baseada na inclusão, igualdade e na democracia participativa, foi adotado, durante a administração municipal (1989-1993) da prefeita Luiza Erundina (SOUZA, 2010) e, posteriormente, referenciou a concepção dos CEUs no governo de Marta Suplicy (2001-2004) (PADILHA; SILVA, 2004) e deu continuidade na gestão de Fernando Haddad (2013-2016).

Segundo Rosa Maria de F. Rogerio, registros oficiais sobre as diretrizes do planejamento educacional do município de São Paulo, de 2001, trazem o conceito de "Cidade Educadora". (ROGERIO, 2015). De acordo com tal conceito, uma "Cidade Educadora" é quando apresenta alguns requisitos descritos abaixo por Rosely Fátima dos Santos Arrojo:

É igualmente uma cidade que se relaciona com o seu meio envolvente, com outros centros urbanos de seu território e com cidades de outros países. O seu objetivo permanente será o de aprender, trocar, partilhar e, por consequência, enriquecer a vida dos seus habitantes. A cidade educadora deve exercer e desenvolver essa função paralelamente às suas funções tradicionais (econômica, social, política de prestação de serviços), tendo em vista a formação, a promoção e o desenvolvimento de todos os seus habitantes. Deve se ocupar prioritariamente com as crianças e jovens, mas com a vontade decidida de incorporar pessoas de todas as idades, numa formação ao longo da vida. (ARROJO, 2015, p. 40)

A concepção de política educacional da Secretaria Municipal de Educação de São Paulo, na gestão da prefeita Marta Suplicy, também teve como referência "a democratização da gestão, a democratização do acesso e da permanência e a qualidade social da educação" (ROGERIO, 2015, p. 57). É a partir da orientação da formação cidadã que o projeto educacional do CEU foi concebido.

Os CEUs (Centros Educacionais Unificados) são uma rede de equipamentos públicos de educação, cultura, esporte e lazer localizados nas regiões desassistidas de infraestrutura pública e foram implantados, em 2003, em São Paulo. O objetivo do projeto dos CEUs, que completou quinze anos de existência no decorrer desta pesquisa de mestrado, é proporcionar à população cultura, esporte e lazer para um público que não necessariamente esteja matriculado em uma unidade escolar municipal. A proposta de criação dos Centros Educacionais Unificados é de tornar os espaços da cidade educativos, de modo que essa função educadora não esteja restrita aos CEUs. Objetiva-se, portanto, "romper com o confinamento à que está submetida a população, presa em suas casas ou por falta de segurança ou por falta de espaços de lazer, esportes e cultura para usufruir." (DORIA; PEREZ, 2007, p. 161) 


\subsubsection{O funcionamento dos CEUs}

$\mathrm{O}$ primeiro conjunto de normas que organizou o funcionamento dos CEUs foi desenvolvido pela Fundação Instituto de Administração (FIA/USP), pelo Centro de Estudos e Pesquisas em Educação, Cultura e Ação Comunitária (Cenpec) e pelo Instituto Paulo Freire (IPF), quando faziam o assessoramento à Prefeitura de São Paulo, ainda na gestão da prefeita Marta Suplicy (2001-2004). O Regimento Padrão dos CEUs foi aprovado em 30 de novembro de 2004, por meio do Decreto $\mathrm{n}^{\circ}$ 45.559. Por isso, de 2003 até 2004, os primeiros centros educacionais funcionaram sem o modelo organizacional (SANCHES, 2014), visto que os equipamentos começaram a ser inaugurados a partir de $1^{\circ}$ de agosto de 2003 . O Regimento Padrão é um documento referência que contém as diretrizes com base na gestão democrática, tornando possível a administração cotidiana dos Centros Educacionais Unificados.

O Decreto $\mathrm{n}^{\circ} 46.701$, de 1 de dezembro de 2005, delega ao Secretário Municipal de Educação aprovar o Regimento Padrão dos CEUs, por meio de Portaria, revogando o primeiro Regimento Padrão. Em 23 de dezembro de 2005, a Portaria da Secretaria Municipal da Educação SME no 7.356 aprova o novo Regimento Padrão dos Centros Educacionais Unificados, sendo que o regimento sofre sua terceira modificação no ano seguinte, em 2006, com a Portaria $n^{0} 4.672$.

Em 2014, o Decreto $n^{\circ} 54.823$, de 7 de fevereiro, ao dispor sobre a gestão compartilhada dos CEUs entre as Secretarias Municipais de Educação, de Cultura e de Esportes, Lazer e Recreação revoga o Decreto $n^{\circ} 46.701$ de 2005. Até o momento, a quarta versão do Regimento Padrão dos CEUs vigora, aprovado pelo Decreto n ${ }^{\circ} 57.478$, de 28 de novembro de 2016. Cada governo que esteve à frente da Prefeitura de São Paulo, até então, aprovou seu Regimento Padrão dos CEUs, com exceção do governo Doria-Covas, que ainda cumpre o primeiro mandato de sua gestão.

No regimento constam a natureza, os fins, a estrutura organizacional, instâncias de participação, o processo de planejamento, elaboração e avaliação do projeto educacional, assim como informações sobre seu funcionamento e da comunidade usuária.

O projeto arquitetônico padrão que originou os CEUs engloba três prédios distribuídos em 13 mil metros quadrados de área construída. Esses três prédios compreendem as áreas didática, cultural e o prédio redondo. À área didática, são reservadas as salas de aula, biblioteca, telecentro e as unidades escolares, além da cozinha e refeitório. O prédio cultural abriga salas de teatro, ateliê, sala de dança, estúdio de música e ginásio de esportes, além da área administrativa e de gestão do CEU. E o prédio redondo, destinado às salas modulares. (DORIA; 
PEREZ, 2007). Existem 46 Centros Educacionais Unificados (CEUs) em funcionamento distribuídos na cidade de São Paulo, que foram inaugurados no período de 2003 a 2015: 20 CEUs na região Sul; 16 na Leste; 7 na região Norte e 3 na região Oeste. (APÊNDICE 1).

A infraestrutura de cada CEU difere de cada unidade, entretanto todos os centros educacionais possuem áreas educacionais, esportivas e culturais. $\mathrm{Na}$ área didática, os CEUs possuem, pelo menos, as unidades escolares dos CEI, Emei e Emef. No que se refere à infraestrutura esportiva e cultural, possuem em comum o espaço físico da biblioteca, teatro, piscinas, quadras e salas de ginástica, dança ou de artes marciais. Alguns edifícios preveem área física de camarins, telecentro, pista de skate, salas multiuso, brinquedoteca, laboratório com impressora 3D, pista de cooper, assim como a oferta de ensino de educação básica na modalidade Educação de Jovens e Adultos (EJA) e de Educação Superior nos Polos da Rede UniCEU. (APÊNDICE 2).

O CEU funciona diariamente, de segunda a sexta-feira, das $7 \mathrm{~h}$ às $22 \mathrm{~h}$, aos sábados e domingos, das $8 \mathrm{~h}$ às $20 \mathrm{~h}$. Nos feriados, pontos facultativos e nos dias definidos como de suspensão de atividades das unidades educacionais, o seu funcionamento é das $8 \mathrm{~h}$ às $18 \mathrm{~h}$.

O horário de funcionamento do CEU escolhido para esta pesquisa, assim como dos outros Centros Educacionais Unificados que mantêm atendimento à Educação de Jovens e Adultos (EJA) e/ou da Rede UniCEU/UAB, estende-se até às $23 \mathrm{~h}$.

$\mathrm{O}$ quadro de funcionários remunerados que mantêm vínculo empregatício nos CEUs divide-se entre os funcionários públicos concursados; o quadro de pessoal nomeado politicamente e os trabalhadores terceirizados do serviço de limpeza, conservação e segurança.

\subsubsection{As mudanças dos CEUs ao longo dos anos}

Após o término da gestão petista no executivo municipal da Marta Suplicy (2001-2004), José Serra (2005-2006), do Partido da Social Democracia Brasileira (PSDB), assume a prefeitura e cancela as construções de mais 24 CEUs que estavam previstas ainda na gestão anterior. Entretanto, após abandonar a pasta para a disputa presidencial, seu vice-prefeito, Gilberto Kassab (2006-2012), do Partido Democratas (DEM/2006-2011) / Partido Social Democrático (PSD/2011-2012) assume o cargo e retoma as obras. Kassab, reeleito prefeito de São Paulo, entrega 24 CEUs durante a gestão Serra-Kassab (2005-2012).

Em 2013, pelo Partido dos Trabalhadores (PT), Fernando Haddad (2013-2016) assume o executivo municipal e entrega $1 \mathrm{CEU}$, em Heliópolis, no ano de 2015. Em seguida, João Doria (2017-2018) é eleito prefeito em 2017, pelo Partido da Social Democracia Brasileira (PSDB), e permanece no posto por quinze meses quando abandona a prefeitura para a disputa do cargo 
do governo estadual de São Paulo. Durante sua gestão, prorroga a suspensão de obras dos CEUs. Seu vice, Bruno Covas (2018-2020), do PSDB, assume seu posto com a garantia de retomar as obras paralisadas nos doze CEUs da cidade (SALDANHA, 2018).

Desde que foi criado, o CEU esteve vinculado à Secretaria Municipal de Educação e passou por quatro momentos que se distinguem entre si quanto ao projeto arquitetônico, concepção e infraestrutura. Desde a criação dos CEUs, o executivo municipal da cidade e, consequentemente, a gestão dos CEUs se alternaram na administração dos dois principais partidos: PT e PSDB. O primeiro momento refere-se à gestão de Marta Suplicy (2001-2004), do PT; o segundo momento diz respeito à gestão José Serra e Gilberto Kassab (2005-2012) do PSDB, seguido da gestão de Fernando Haddad (2013-2016), do PT e, finalmente, de João Doria e Bruno Covas (2017-2020), do PSDB.

\subsubsection{Gestão Marta Suplicy}

O primeiro momento dos CEUs compreende o período de criação dos centros educacionais durante a gestão da Prefeita Marta Suplicy (2001-2004), quando foram entregues 21 equipamentos educacionais ${ }^{3}$ à população das regiões periféricas de São Paulo.

Como o projeto do CEU envolvia outras secretarias para além da educacional, foi necessária a elaboração de um ordenamento jurídico interno de gestão dos equipamentos denominado, posteriormente, de Regimento Padrão dos CEUs. Foi durante o governo da prefeita Marta Suplicy, do PT, que foi elaborado o primeiro conjunto de normas e orientações legais que definiu as atribuições, natureza, estrutura organizacional, composição, funcionamento dentre outras determinações dos CEUs. O primeiro Regimento Padrão dos CEUs foi aprovado em Decreto $\mathrm{n}^{\mathrm{o}} 45.559$, de 30 de novembro de 2004, ao final do mandato da prefeita.

No primeiro momento, os CEUs possuíam uma estrutura maior. Todos os teatros foram construídos com capacidade de 450 lugares, ao passo que nas outras gestões municipais foi reduzida a capacidade de alguns equipamentos, como o CEU Uirapuru, no Jardim Paulo VI, região oeste de São Paulo, inaugurado em 2009, com teatro com capacidade para 184 lugares. Como observado por Lilian Cristina Pereira Cangussu, os CEUs construídos na gestão Suplicy tiveram custo menor em comparação às obras da gestão Kassab, que apresentaram projeto de menor tamanho (CANGUSSU, 2010).

\footnotetext{
${ }^{3}$ Foram construídos os CEUs de Jambeiro, Rosa da China, Perus, Cidade Dutra, Aricanduva, Parque Veredas, Butantã, Vila Atlântica, Meninos do Ipiranga, São Mateus, Pêra Marmelo, Inácio Monteiro, Vila Curuçá, Parque São Carlos, Alvarenga, Navegantes, Três Lagos, São Rafael, Campo Limpo, Paz e Casa Blanca.
} 
$\mathrm{Na}$ ocasião da pesquisa, havia 46 CEUs distribuídos nos bairros afastados do centro da cidade de São Paulo, sendo que desse total 21 foram entregues à população na gestão da prefeita petista Marta Suplicy (2001-2004), período das inaugurações que compreende de 01 de agosto de 2003 até 27 de junho de 2004, conforme APÊNDICE 1.

No APÊNDICE 2 é possível observar que os equipamentos construídos na gestão da prefeita Marta Suplicy possuíam, predominantemente, pista de skate e camarins, sendo que esse último teve o número reduzido pela metade nas gestões posteriores.

De acordo com Balanço da Gestão (SECRETARIA DE GOVERNO, 2004), em cada unidade do CEU construído na gestão petista, foram ofertadas 300 vagas em creches, 840 vagas em Emeis, 1.260 vagas em Emefs, 2.400 alunos atendidos, 450 lugares em teatro/cinema, 3 piscinas, biblioteca, campo de futebol, ginásio coberto, sala de dança, quadro poliesportiva, Telecentro ${ }^{4}$, padarias-escolas e pista de skate, em uma área de $13 \mathrm{mil} \mathrm{m}^{2}$.

Vale lembrar que quando da sua implementação, os CEUs passam a estar vinculados à Secretaria Municipal de Educação e articulados à Secretaria de Cultura, a Secretaria de Esporte, Lazer e Recreação e outras Secretarias, como a de Comunicação e Informação Social e a Secretaria Municipal das Subprefeituras.

\subsubsection{Gestão Serra-Kassab}

A gestão municipal seguinte, de José Serra e seu vice-prefeito Gilberto Kassab, que assumiria depois, ficou conhecida pela gestão Serra-Kassab (2005-2012). Foram inauguradas 24 unidades (PARTIDO SOCIAL DEMOCRÁTICO, 2016) no período de sua gestão no município de São Paulo.

Durante a administração do prefeito José Serra (2005/06) foi publicado o Decreto $\mathrm{n}^{\mathrm{o}}$ 46.701, de 01 de dezembro de 2005, que delega competência ao Secretário Municipal para aprovar Regimento Padrão dos CEUs, revogando o Decreto n ${ }^{\circ}$ 45.559/04 da gestão municipal anterior. Segundo Simone Aparecida Preciozo Figliolino (2014), essa normativa excluiu o caráter intersetorial e intersecretarial do projeto original dos CEUs, vinculando a administração unicamente pela pasta da Secretaria Municipal de Educação. Alguns dias depois do decreto, em 23 de dezembro de 2005, a Portaria da Secretaria Municipal de Educação SME nº 7.356 aprovou o segundo Regimento Padrão dos CEUs.

\footnotetext{
${ }^{4}$ Trata-se de um espaço público onde pessoas podem utilizar microcomputadores, a internet e outras tecnologias digitais que permitem coletar informações, criar, aprender e comunicar-se com outras pessoas, enquanto desenvolvem habilidades digitais essenciais do século XXI. O programa foi institucionalizado pela Lei Municipal ${ }^{\circ}$ 14.668/2008 e regulamentado pelo Decreto Municipal n ${ }^{\circ}$ 50.554/09, que estabeleceu a Política Municipal de Inclusão Digital do Município de São Paulo.
} 
Figliolino (2014) lembra algumas modificações da nova gestão na área física dos Centros Educacionais Unificados em comparação ao projeto original, mesmo nos equipamentos que eram previstos pela gestão anterior. Ao afinal do ano de 2005, Serra inicia a retomada das obras de cinco CEUs no município, com o discurso de defesa de redução de gastos e diferenças de conceito relativas aos CEUs originais. Ainda segundo a autora, essas obras já haviam sido desapropriadas e licitadas no governo anterior de Marta Suplicy. Dentre as alterações observadas por Figliolino (2014), relacionadas direta e indiretamente ao Conselho Gestor, está a construção da quadra de esportes na área externa a do bloco da gestão do CEU, o que passou a excluir a presença da comunidade no prédio da gestão.

Figliolino (2014) relata também alteração ocorrida na política pública de inclusão digital CEU na gestão de José Serra, em comparação com a gestão anterior, de Marta Suplicy. Segundo a autora, houve a descaracterização do projeto original dos Centros Educacionais Unificados (CEUs) na gestão de Serra, que não viu a importância da implementação de um Conselho Gestor para os telecentros, tanto neles quanto fora do espaço deles:

No início de 2007 assumiu a coordenação geral de inclusão digital (CID) da Secretaria de Participação e Parceria, o sociólogo Douglas César Gonzaga, que chegou a declarar-se contrário à formação de Conselhos. (FIGLIOLINO, 2014, p. 47)

Ydeliz Coelho de Souza Sanches (2014) lembra da mudança do formato da gestão dos Centros Educacionais Unificados na gestão Serra-Kassab em comparação com a proposta original. Conforme observa em estudo, houve a "perda de elementos importantes a uma proposta de gestão democrática: a eleição para gestor deixou de existir e a assembleia, mesmo sendo de caráter consultivo, foi extinta" (SANCHES, 2014, p. 315). O artigo 13 do Decreto $\mathrm{n}^{\circ}$ 7.356/05 da gestão Serra aborda a nomeação do gestor pelo executivo municipal. Outra modificação observada na normativa foi a inclusão da Associação de Pais, Mestres e Servidores, Usuários e Amigos do Centro Educacional Unificado (Apmsuac), classificada por Pacheco $(2009$, p. 106) como "retrógrada instância" similar às conhecidas APMs (Associações de Pais e Mestres) que, ainda segundo o autor, são instituições "controladas" pelo gestor do CEU (PACHECO, 2009, p. 106).

O horário de funcionamento dos CEUs foi alterado, tanto no regimento da gestão Serra $\left(n^{\circ} 7.356 / 05\right)$ quanto na continuidade da gestão Kassab ( $\left.n^{\circ} 4.672 / 06\right)$. Originariamente, os CEUs que funcionavam das $7 \mathrm{~h}$ da manhã até às $23 \mathrm{~h}$, de segunda a sexta-feira, passaram a abrir no mesmo horário e a fechar uma hora mais cedo, às $22 \mathrm{~h}$. Aos sábados, anteriormente, funcionavam das $8 \mathrm{~h}$ às $22 \mathrm{~h}$, e com a mudança, passaram a fechar às $20 \mathrm{~h}$. Chama atenção para 
a redução de horas de funcionamento dos CEUs, sobretudo aos sábados, quando os usuários tendem a ter mais tempo disponível para o lazer, a prática de esporte e as atividades culturais.

Sanches (2014) nota que, no mesmo período, a gestão local passa a ser organizada a partir do trabalho desenvolvido pelo gestor do CEU, do Conselho Gestor e do Colégio de Integração. Por Colegiado de Integração do CEU se entende a esfera participativa coordenada pelo gestor, de caráter executivo, que trata da operacionalização e execução das ações deliberadas e encaminhadas no Conselho Gestor. O Colegiado de Integração, ao lado das Comissões Temáticas e Apmsuac compunha, naquele período, junto com o Conselho Gestor a gestão do CEU.

Com a saída de Serra, na gestão Kassab (2006/2012), conforme menciona Sanches (2014), algumas alterações legais relacionadas à gestão do CEU ocorreram posteriormente. Foi expedida Portaria da Secretaria Municipal da Educação SME no 4.672, de 05 de dezembro de 2006, que aprovou o terceiro Regimento Padrão dos CEUs, revogando a Portaria SME do ano anterior $\mathrm{n}^{\mathrm{o}}$ 7.356. Em 2008, Gilberto Kassab decreta e promulga dispositivo de Lei $\mathrm{n}^{\mathrm{o}} 14.662$, de 03 de janeiro, que dispõe sobre a criação dos Conselhos Gestores dos CEUs da Rede Direta Municipal.

A ordem $n^{\circ} 50.738$, de 15 de julho de 2009, regulamenta a Lei $n^{\circ} 14.662$, que trata da criação dos Conselhos Gestores dos CEUs, passa a dispor em seu terceiro parágrafo a composição paritária dos membros do Conselho Gestor, descrita a seguir:

I - 6 (seis) representantes dos equipamentos de educação integrantes do CEU, na seguinte conformidade:

a) o Gestor do CEU, na condição de membro nato;

b) o Diretor do Centro de Educação Infantil - CEI;

c) o Diretor da Escola Municipal de Educação Infantil - Emei;

d) o Diretor da Escola Municipal de Ensino Fundamental - Emef;

e) 2 (dois) membros escolhidos dentre integrantes dos Núcleos de Esporte e Lazer e de Ação Cultural e Educacional;

II - 3 (três) representantes de outros equipamentos sociais do entorno do CEU; III - 6 (seis) membros eleitos pelos professores e demais profissionais que atuam nos equipamentos que integram o CEU;

IV - 15 (quinze) membros eleitos pelos alunos, pais e representantes da comunidade do entorno do CEU, assegurando-se a mesma proporção entre eles, ou seja, 5 (cinco) alunos, a partir do $4^{\circ}$ ano do Ciclo I do Ensino Fundamental, 5 (cinco) pais de alunos do CEU e 5 (cinco) representantes da comunidade.

Comparando essa normativa (Lei $\left.n^{\circ} 14.662 / 08\right)$ com a Portaria SME $n^{\circ} 4.672$, aprovada em dezembro de 2006, observa-se a garantia da paridade na composição do Conselho Gestor, já que a normativa anterior $n^{\circ} 7.356 / 05$, aprovada no governo de José Serra previa a composição de um Conselho Gestor de 50\% de representantes da comunidade e 50\% de educadores. 
Adicionando outros elementos em relação à estrutura da instituição dos CEUs e ao regimento da gestão Marta Suplicy, Pacheco (2009) percebe diferenças significativas entre as gestões Serra-Kassab com a de Suplicy. Enquanto essa última parecia indicar uma gestão de caráter popular, mesmo que, de fato, isso nunca tenha ocorrido, a gestão Serra-Kassab nem ao menos possibilitava que a participação democrática ocorresse. O autor refere-se assim à gestão Serra-Kassab:

[...] constituindo-se numa aberração autoritária que ainda assim mantém estruturas supostamente "democráticas", tal como o Conselho Gestor e o Colegiado de Integração, que operam apenas como estruturas de legitimação de proposta educacional, do autoritarismo e até mesmo do desmando. (PACHECO, 2009, p. 106)

\subsubsection{Gestão Haddad}

É o período de administração de Fernando Haddad (2013-2016) à frente do executivo municipal que a pesquisa de mestrado tem como contexto. Não obstante, muitas das experiências relatadas pelas conselheiras entrevistadas tenham ocorrido ao longo de outros anos de participação no Conselho Gestor, além das entrevistas terem sido realizadas em 2018, na gestão Covas, priorizou-se como recorte temporal de análise as atas das reuniões do Conselho Gestor do CEU da gestão de Haddad.

Fernando Haddad participou da origem e concepção dos CEUs na cidade de São Paulo. Foi chefe de gabinete da Secretaria de Finanças, na gestão da Prefeita Marta Suplicy. Paulo Roberto Padilha e Roberto da Silva (2004) relatam os registros que relacionam o envolvimento de Haddad na elaboração do projeto dos CEUs. Em suas palavras:

Dois dos principais nomes do grupo que ajudou a tirar os CEUs do papel, o economista Fernando Haddad e o arquiteto Alexandre Delijaicov reforçam a percepção identificada nas pesquisas conduzidas pelo IPF, de que os CEUs foram concebidos na perspectiva maior de uma Cidade Educadora e como centros de estruturação urbana. (PADILHA; SILVA, 2004, p. 39)

Já, como prefeito, o Plano de Governo (HADDAD, 2012) de Fernando Haddad (20132016) previu a retomada do projeto educacional original da Rede, significando a incorporação de pais e alunos na definição do processo educacional, além da articulação da Cultura, Esporte e Trabalho e a manutenção do estudante na escola, privilegiando os equipamentos e espaços urbanos, tais como teatros, cinemas, parques e praças. Segundo Rodrigues (2018), a Secretaria Municipal de Educação foi responsável pela averiguação e reelaboração da legislação, e à Secretaria de Cultura coube a tarefa de formar o quadro de gestores e coordenadores do CEU. 
O Programa de Metas 2013-2016 do Prefeito Fernando Haddad previu também a construção de 20 novos Centros Educacionais Unificados no município de São Paulo, plano esse que contemplava a articulação das escolas no entorno do CEU para que elas utilizassem o espaço do equipamento educacional. Entretanto, Haddad entregou, em abril de 2015, uma única unidade do Centro Educacional Unificado no bairro de Heliópolis (VIEIRA, 2015).

Durante seu mandato, Haddad firmou o compromisso de consolidar o diálogo social como um instrumento de participação direta no envolvimento dos cidadãos às políticas públicas. Sua gestão (2013-2016) implantou o Programa Território CEU, a partir da convergência entre a política de desenvolvimento urbano e a ampliação da rede de equipamentos de Centros Educacionais Unificados (CEU) em vinte novas unidades (VIEIRA, 2015), com o protagonismo do espaço público na cidade (SÃO PAULO, 2016). Em 2014, promulgou o Decreto $\mathrm{n}^{\mathrm{o}} 54.823$, de 07 de fevereiro de 2014 (SÃO PAULO, 2014), que resgata a proposta original dos CEUs compartilhando a gestão dos equipamentos educacionais com as três Secretarias de Educação, Cultura, Esporte, Lazer e Recreação. A Lei no 16.050, do Plano Diretor Estratégico (PDE) de São Paulo, sancionada por Haddad, em 31 de julho de 2014 (SÃO PAULO, 2014), orienta o ordenamento territorial e as políticas públicas municipais para os próximos dezesseis anos, assim como o Programa Território CEU. Já o artigo 305 do Plano Diretor Estratégico prioriza a implantação de novos Centros Educacionais Unificados (CEU) dentre as ações nos equipamentos sociais e urbanos.

Apresentada na Lei do Plano Diretor $n^{\circ}$ 16.050, de 31 de julho de 2014, a Rede de Estruturação Local, responsável pela articulação das políticas públicas dos setores no território, para a garantia da cidadania e da redução das desigualdades sociais e espaciais, integra a estratégia de desenvolvimento urbano coordenando as políticas públicas no território, cuja rede compreende as futuras Áreas de Estruturação Local (AEL), locais para a implantação dos Projetos de Intervenção Urbana (PIU). São nessas áreas que se propôs abrigar infraestrutura urbana com a rede de habitação de interesse social, regularização fundiária e urbanística de assentamentos precários aliado ao sistema de transporte coletivo e não motorizado e equipamentos sociais. A proposta é que essa nova rede se articule com a existente.

O Plano de Articulação e Integração da Rede de Equipamentos, um dos instrumentos do Plano Diretor Estratégico, prevê a integração da rede em sua expansão, de forma a:

Otimizar e intensificar a ocupação de áreas públicas, equilibrar a oferta de equipamentos sociais pela cidade, reduzir a vulnerabilidade social de setores da cidade ainda não atendidos por creches e Escolas Municipais de Educação Infantil (EMEIs), articular as redes de apoio à população vulnerável por meio da rede de equipamentos integrados no território. (SÃO PAULO, 2016, p. 13) 
Portanto, o Programa Território CEU compreende a nova proposta de trazer um novo equipamento público para uma localidade onde já exista equipamento quanto à articulação da nova ocupação com os espaços públicos do entorno. (SÃO PAULO, 2016, p. 15). Dessa forma, a proposta do Programa Território CEU é a articulação dos 65 equipamentos, novos e já existentes que compõem a Rede CEU.

A seleção das áreas públicas para a implantação dos Centros Educacionais Unificados (CEUs), da gestão do Prefeito Fernando Haddad, considerou dois critérios: (1) critério físico e legal, de áreas públicas, sobretudo da própria Secretaria Municipal de Esportes que atendessem às exigências da legislação ambiental e urbana e (2) critérios urbanísticos, que considerou três fatores: (I) o cruzamento de dados de densidade demográfica por setor censitário; (II) a vulnerabilidade social das famílias, cujos terrenos se aproximassem aos eixos de mobilidade, de forma a ampliar o acesso e alcance territorial do CEU e (III) a demanda por equipamentos de educação infantil. (SÃO PAULO, 2016) De acordo com a gestão do Prefeito Fernando Haddad, das 400 áreas públicas, 120 foram selecionadas para vistorias técnicas, das quais 20 áreas foram selecionadas para a implantação dos novos Centros Educacionais Unificados. Das 20 áreas, 12 são centros esportivos em funcionamento que serão incorporados aos novos CEUs (SÃO PAULO, 2016).

Paralelamente ao trabalho de seleção dos terrenos, foi iniciada tarefa de atualização do programa do CEU. Naquele momento, após 10 anos de existência, o programa original do CEU foi revisado, considerando a mudança da estrutura demográfica, socioeconômica e cultural da população. A partir do caráter multidisciplinar do projeto original dos CEUs, os novos Centros Educacionais Unificados incluíram ao Programa Território CEU novas atividades e a (1) promoção da educação em tempo integral; (2) promoção de atividades culturais independentes locais, ligadas à cultura digital e (3) programas de assistência social, por meio do Centro de Referência de Assistência Social (Cras). Os programas como Juventude Viva, Educação para os Direitos Humanos, Programa Nacional de Acesso ao Ensino Técnico e Emprego (Pronatec), Programa VAI e VAI-TEC compõem a proposta dos novos CEUs que serão sedes de desenvolvimento de atividades direcionadas ao público-alvo de jovens da política pública. (SÃO PAULO, 2016) Contudo, além da importância do diálogo social na construção da política pública, foi considerada a valorização do espaço público no interior da política pública com a integração dos novos CEUs com os equipamentos e espaços públicos do entorno, "através da requalificação de caminhos de pedestres e ciclistas, abrindo um amplo leque de possibilidade 
para a programação compartilhada de ações no âmbito do território". (SÃO PAULO, 2016, p. 27)

Durante o processo de definição do Território CEU, realizaram-se oficinas com a comunidade e encontros com coletivos de cultura das regiões. A Secretaria Municipal de Cultura de São Paulo (SMC) construiu uma cartografia colaborativa e afetiva das informações de intervenção urbana da cidade. Esse "diálogo aberto entre técnicos e comunidade, pautado numa escuta fluida, ininterrupta, espontânea" procurou "ir além das dinâmicas tradicionalmente adotadas para audiências públicas, nas quais o diálogo se baseia na linguagem verbal, com limitação de tempo para falas, o que acaba por restringir a espontaneidade, o diálogo e a prospecção de desejos" (SÃO PAULO, 2016, p. 30). Importante destacar esse formato adotado nas audiências públicas, considerando presente estudo que trata do espaço do Conselho Gestor do CEU na gestão Haddad. Esse modelo de captação de informações serviu de insumo para a definição dos principais pontos do projeto que, em um segundo momento, em uma rodada de apresentação e coleta de sugestões com os atores, possibilitou a incorporação de ajustes para a implantação final. (SÃO PAULO, 2016)

Em audiência pública, em 10 de outubro de 2014, a Secretaria de Infraestrutura Urbana e Obras (Siurb), em conjunto com a Secretaria Municipal de Desenvolvimento Urbano (SMDU), apresentaram o projeto dos novos CEUs, com meta de contratar as obras de construção de mais de 20 CEUs até 2016 (CIDADE DE SÃO PAULO, 2014) Em 2015, foi publicada no Diário Oficial do Município de São Paulo a abertura de licitação de proposta comercial para a construção dos primeiros oito territórios CEUs, nas seguintes regiões: Freguesia do Ó, Parque Novo Mundo, na zona norte, Carrão, José de Anchieta, Vila Alpina, Parque do Carmo, São Miguel Paulista e Jardim São Pedro, na zona leste (DIÁRIO OFICIAL DA CIDADE DE SÃO PAULO, 2015).

A Portaria da Secretaria Municipal de Educação n ${ }^{\circ}$ 7.720, de 20 de novembro de 2016, ao instituir a política de transparência ativa e Dados Abertos e ao Plano Anual de Transparência Ativa e Dados Abertos (PTDA), no âmbito da Secretaria Municipal de Educação (SME), aumenta a transparência da ação governamental e possibilita o aumento da participação popular, tanto presencial quanto a digital. A incorporação dos canais da internet, seja pelas redes sociais quanto por outros canais institucionais, tem como estratégia o aumento da participação popular (SANTOS, 2016, p. 37). No item II da redação do artigo $2^{\circ}$ da mesma normativa, estabelece que um dos objetivos da Política de Transparência Ativa e de Dados Abertos da Secretaria Municipal de Educação é o fomento do "controle social sobre a SME e a participação cidadã nas políticas educacionais" (SÃO PAULO, Portaria 7.720/ 2016). 
A mesma normativa, em suas disposições finais, estabelece que um dos eixos, temas e itens prioritários do $1^{\circ}$ Plano Anual de Transparência Ativa e Dados Abertos da SME é do eixo da Gestão Democrática que inclui os Projetos Políticos-Pedagógicos (PPP) e os Regimentos Escolares (RE), além da Associação de Pais e Mestres (APM) e a Associação de Pais e Mestres, Servidores, Usuários e Amigos dos Centros Educacionais Unificados (Apmsuacs). O eixo da participação inclui atas e integrantes do Conselho de Alimentação Escolar (CAE), do Conselho Municipal de Educação (CME) e do Conselho de Representantes do Conselho de Escola (Crece).

O Decreto $n^{\circ} 57.478 / 16$ é resultado de discussões realizadas no Seminário Nacional dos CEUs, ocorrido em 02 e 03 de dezembro de 2014, em Brasília, ainda quando Dilma Rousseff era presidenta. O Seminário Nacional dos CEUs reuniu gestores e comunidades de cerca de 140 municípios e de 342 CEUS que foram construídos ou que estavam em fase de construção, nas 27 unidades da Federação. Contou com a presença de aproximadamente 300 pessoas em cada um dos dias, com o objetivo de integrar o conjunto de ações do Ministério da Cultura (Minc) no sentido de fomento e orientação da mobilização social e a infraestrutura nos municípios contemplados com o programa CEUs (CARVALHO, 2014).

A programação do Seminário contou com um momento de capacitação para gestores e comunidades dos CEUS, nas temáticas como obras, equipamentos e mobiliário, mobilização social e gestão, atas nacionais para a aquisição de equipamentos e mobiliário e o sistema de gestão online, e envolveu a participação do Ministério das Cidades, Ministério do Esporte, Ministério do Trabalho e Emprego, Ministério do Desenvolvimento Social, Ministério da Justiça e Secretaria Nacional de Juventude.

Ao final da gestão, Fernando Haddad também atualiza o Regimento Padrão dos CEUs, com o Decreto ${ }^{\circ} 57.478$, que passou a definir:

$\S 2^{\circ} \mathrm{O}$ Conselho Gestor é a instância máxima de decisão, de caráter permanente para as decisões administrativas e educacionais, cabendo-lhe também liderar e articular a participação dos diferentes colegiados e demais instância de participação. (SÃO PAULO, 2016)

Comparando o primeiro Regimento Padrão do CEU com a mesma legislação aprovada na gestão de Haddad, é possível observar que a norma de 2004, em seu artigo 38, define a composição "tripartite" do Conselho Gestor, formado por $1 / 3$ de membros de funcionários públicos municipais, com equilíbrio de funcionários lotados e não nos CEUs; $1 / 3$ de membros da comunidade de usuários do CEU cadastrados regularmente e 1/3 de representação de organização da sociedade civil na área de abrangência do Centro Educacional Unificado. Já o 
artigo 36 da normativa de 2016 mantém o caráter "paritário" do colegiado, caraterística inicialmente instituído pelo Decreto $\mathrm{n}^{\mathrm{o}}$ 50.738/09, assinado por Kassab. Nos incisos I e II, a regulamentação de 2016 prevê a composição de 15 representantes distribuídos na diretoria do CEI, Emei e Emef do CEU além do próprio gestor.

Enquanto a concepção inicial do CEU não especificava a composição dos três representantes de outros equipamentos sociais do entorno, o novo decreto de 2016 deixa claro o caráter intersetorial do colegiado ao especificar que poderão fazer parte representantes do polo de apoio presencial da Rede das Universidades dos CEUS (UniCEU), os Centros de Educação Infantil (CEIs) da rede direta e conveniada, as Escolas Estaduais (EEs), as Escolas Municipais de Ensino Fundamental (Emefs), as Escolas Técnicas Estaduais (Etecs), a Unidade Básica de Saúde (UBS), o Centro de Referência de Assistência Social (Cras), o Centro de Referência Especializado em Assistência Social (Creas), o Clube da Comunidade (CDC), o Centro para Criança e Adolescente (CCA), Casas de Cultura e outros.

Outra modificação em relação ao regimento original de composição do Conselho Gestor, com o decreto de 2016, deve-se ao detalhamento da composição entre os 15 representantes eleitos pelos alunos/as, pais, mães e representantes da comunidade do entorno do CEU. Passou a especificar a composição numérica de 5 estudantes, maiores de 10 anos, podendo ser representações de unidades escolares internas ou externas ou de unidades acadêmicas.

Legalmente, a normativa passou a detalhar a composição de 5 representação de familiares de estudantes do território CEU, assim como especificou, de forma pormenorizada, as 5 representações restantes que devem fazer parte de associações de moradores e/ou de bairro de Conselhos, tais como do meio ambiente e sustentabilidade, de direitos humanos, de idosos, de pessoa com deficiência, de diversidades culturais, de movimentos etnicorraciais (negro, indígena e imigrante), gênero e LGBT, educacionais, em movimentos por educação, da cultura periférica, esportivos, da economia solidária, religiosos e entidades empresariais (SÃO PAULO, 2016). O Decreto $n^{0} 57.478 / 16$ instituiu a composição paritária de gênero dos membros do Conselho Gestor, atribuindo representação de 5 representantes da comunidade.

Observando as atribuições originais do Conselho Gestor, a nova normativa mantém-se praticamente a mesma, com exceção do acréscimo do item XI, ao mencionar que caberá ao colegiado aprovar e participar do Regimento Interno do CEU, que trata do equipamento, na definição da natureza e os usos de cada espaço, seus horários de funcionamento e direitos e deveres dos usuários. 


\subsubsection{Gestão Doria-Covas}

O Programa de Metas da chapa Doria-Covas (2017-2020) incluía a entrega de 12 CEUs, localizados nas seguintes localidades: José Bonifácio/São Pedro, São Miguel, Clube Escola Freguesia do Ó, Parque Novo Mundo, Cidade Tiradentes, Tremembé/Jardim Joamar, Carrão/Tatuapé, José de Anchieta, Taipas, Pinheirinho D’ água, Clube Escola Vila Alpina e Parque do Carmo. Em 2018, a Prefeitura prometeu também a retomada de obras interrompidas em 2016.

Matéria do jornal Folha de São Paulo (FUHRMANN, 2017) informou que a administração do prefeito João Doria retirou investimento da ordem de 30 milhões em CEUs para o remanejamento de construção de creches, após a prefeitura suspender 50 obras, principalmente na periferia, nas áreas de educação e saúde. De acordo com jornal, a suspensão inicial foi de 120 dias, incluiu 5 CEUs, dentre outros equipamentos, motivada pela crise econômica. Embora a reportagem da Folha de São Paulo alegue que não consta no Plano de Metas do prefeito João Doria nenhuma menção à construção dos CEUs, é possível verificar na lista de metas do documento (CIDADE DE SÃO PAULO, 2018), linha 45, página 09, o Objetivo Estratégico 23.1, da entrega de 12 CEUs. Também, na página 61 do Plano de Metas, consta a criação de novos equipamentos de educação e saúde com a previsão orçamentária para o cumprimento das metas no valor total de $\mathrm{R} \$ 747,1$ milhões.

Em entrevista ao jornal Folha de São Paulo, (SALDAÑA, 2018), em 27 de janeiro de 2018, o então Secretário Municipal da Educação da gestão João Doria, Alexandre Schneider, alega a pendência de estudo de demanda e de recursos oriundos de privatizações e do governo federal para a retomada das obras dos CEUs.

A gestão da Prefeitura (2017-2020), administrada pelo vice-prefeito Bruno Covas do Partido da Social Democracia Brasileira (PSDB), assumiu o posto do prefeito Doria, que saiu do cargo, em 2018, quando se lançou na disputa pela candidatura ao governo estadual de São Paulo.

O detalhamento do Plano de Metas (2017-2020), como parte da meta 17, prevê que em todos 46 equipamentos educacionais unificados sejam transformados em polos de inovação em tecnologias e práticas pedagógicas. Essa proposta inclui a implantação de rede de laboratórios de Educação Digital, experimentação e aprendizagem em todas as escolas de ensino fundamental e dos Centros de Educação Unificados da rede municipal, constando a execução orçamentária, em 2017, no valor total de $\mathrm{R} \$ 31,39$ milhões (investimento de R \$ 27,72 milhões somado ao custeio de 3,67 milhões). 
Em matéria publicada em sítio (LAGES, 2018) na internet, em 13 de agosto de 2018, as obras dos 20 CEUs que não foram concluídos durante a gestão de Haddad (2013-2016) foram paralisadas pela gestão Doria (2017-2018) e de Bruno Covas (2018-2020). A mesma reportagem relata que a suspensão das obras dos CEUs acarretou problemas para a comunidade local onde as obras estão inacabadas. Interessante que conforme já descrito detalhadamente, a definição do Território CEU na gestão Haddad tenha ocorrido em constante diálogo com a comunidade. A reportagem traz relatos de alguns moradores dos locais onde as obras estão suspensas afirmando serem contrários às obras, por acreditarem ser desnecessárias, e eles até mesmo acusam o poder público de não terem sido consultados antes das construções:

A Associação dos Condomínios do Morumbi Sul (ACMS), com o apoio dos moradores das regiões de Piracuama e Vila Cais, pressionaram a Prefeitura sobre o projeto, pois alegaram que ele não foi discutido em audiência pública e nem constava no Plano de Metas da gestão Haddad. (LAGES, 2018)

Entretanto, em outro trecho da reportagem, outro morador confirmou que o poder público realizou consultas com "várias reuniões com o poder público para que pudéssemos dar continuidade às atividades do centro esportivo e não deixá-lo abandonado". (LAGES, 2018)

Em outra matéria jornalística, Saldanha (2018) menciona que as obras dos 12 CEUs serão retomadas pela gestão Covas, após terem sido abandonadas por Haddad.

Embora esse subitem do capítulo tenha apresentado breve relato das ações relevantes das gestões municipais durante o intervalo de tempo de existência dos CEUs, ressalto que o período de abrangência da pesquisa contempla a gestão do prefeito Fernando Haddad (20132016). Entretanto, o resgate do histórico dos CEUs das outras administrações ajuda na compreensão da trajetória do projeto dos CEUs. Além disso, as experiências relatadas pelas conselheiras extrapolam o período de recorte de gestões. $\mathrm{O}$ foco da pesquisa são os anos de 2013 a 2016, da gestão Haddad, mas para isso foi necessário fazer uma análise pregressa, desde 2003, por todas as gestões, e avançar um pouco além da gestão Haddad, já que as entrevistas foram realizadas em 2018 (gestão Doria-Covas), com uma mudança na coordenação do próprio CEU examinado. Embora a pesquisa aqui apresentada não tenha condições de avaliar outras gestões, é intenção dialogar com todos os relatos das mulheres entrevistadas, porque elas revelam formas de funcionamento e vivências pessoais que extrapolam as gestões. 


\subsection{SOBRE O CONSELHO GESTOR DOS CEUS}

A raiz etimológica da palavra "conselho" é latina e possui o significado de "tanto ouvir alguém quanto submeter algo a uma deliberação de outro, após uma ponderação refletida, prudente e de bom senso". (CURY, 2000, p. 47).

Para falar dos Conselhos Gestores, é preciso entender esse mecanismo de participação institucional tendo como referência a promulgação da Constituição Federal (BRASIL, 1988) e de Emendas Constitucionais (EC) populares, que instituem a participação de trabalhadores, aposentados, empregadores, comunidade, população e sociedade civil e de órgãos gestores consultivos na gestão das políticas públicas e de combate à pobreza, principalmente em espaços de participação ligados às áreas de educação, saúde e habitação.

Mas vale ressaltar que antes da Constituição de 1988 já havia mecanismos de participação popular, como as agências públicas e as assembleias populares. Destacam-se os movimentos de base e de bairro, nos anos de 1980, organizados por moradores das periferias que demandavam reivindicações por infraestrutura (água, luz, asfalto e esgoto) próprios da perspectiva do mundo cotidiano da família, e, portanto, de identificação social da mulher (SARTI, 2004, p. 40). A institucionalização do movimento direcionou as organizações para as agências financiadoras que, no caso da saúde da mulher, fez emergir os "direitos reprodutivos" questionando o uso do corpo da mulher, em especial pela ginecologia e pela obstetrícia, em temas relacionados às tecnologias reprodutivas. No plano governamental, criaram-se os Conselhos da condição feminina, em todas as esferas de governo, e o problema da violência contra a mulher passou a ser tratado em delegacias específicas, que passou a ser encarado sob o prisma da saúde. Tânia Brabo (2008) lembra que não havia consenso do movimento feminista sobre a criação de Conselhos relacionados à defesa dos direitos das mulheres, pois a incorporação do Estado das pautas feministas poderia levar a uma perda de autonomia do movimento.

Soraya Vargas Côrtes (2007, p. 125) aponta que em diversas áreas e níveis da administração pública no Brasil foram criados mecanismos participativos após a Constituição de 1988, com destaque para os “conselhos de políticas públicas, nas áreas de saúde, trabalho e emprego, assistência social, desenvolvimento rural, educação, meio ambiente, planejamento e gestão urbana, entorpecentes, e os Conselhos de direitos da criança e do adolescente, do negro, da mulher, dos portadores de deficiência, do idoso". Como parte do processo de descentralização política, a autora chama atenção para o papel central do município na tomada 
de decisões e do protagonismo dos Conselhos municipais vinculados à gestão pública no processo.

A Associação de Professores do Ensino Oficial do Estado de São Paulo (Apeosp), no âmbito educacional, no final dos anos 1970, institui em sua pauta de reivindicações a democratização da gestão escolar e a instituição dos Conselhos Escolares (GARCIA, 2006). A Constituição de 1988 consolida e amplia a institucionalidade dos espaços de participação popular, por intermédio de artigos específicos, e ela vincula as políticas públicas às instâncias participativas e o orçamento a alguns setores da sociedade. Os dirigentes municipais tornam-se gestores, não somente de recursos financeiros, característica comum a essas novas formas de instâncias, mas sobretudo na regulação de serviços, na oferta de benefícios, de bens e serviços no território. Como pré-requisito fundamental dessa participação é a existência de espaço público institucionalizado para as atividades (CÔRTES, 2007).

Leonardo Avritzer (2008, p. 44) argumenta que, durante o século XX, houve uma ampliação da participação da população de baixa renda nas práticas participativas. $\mathrm{O}$ Orçamento Participativo (OP), inicialmente em Porto Alegre, os Conselhos Gestores de Políticas Públicas e os Planos Diretores se constituíram como os três principais formatos de instituições participativas, cujo compartilhamento do poder público com a população desenharam um formato de cogestão entre governo e comunidade.

O mais importante é destacar o caráter participativo da chamada Constituição Cidadã, sobretudo no campo das políticas públicas. Nesse sentido, a agenda dos movimentos sociais teve como principal pauta a inclusão de mecanismos institucionais de participação em várias áreas das políticas públicas (ABERS; KECK, 2008), mecanismos esses que devem ser zelados na garantia dos direitos básicos dos cidadãos.

Os Conselhos Gestores de políticas públicas são considerados uma das experiências de democracia participativa no Brasil recentes, e atribui-se à sua novidade o caráter da institucionalidade do diálogo social entre governo e sociedade, na alocação mais justa e eficiente de recursos públicos (TATAGIBA, 2004).

A Lei $n^{0} 8.142$ (BRASIL, 1990) faz referência à participação e ao financiamento da saúde no país, via Conferência e Conselho de Saúde, que aparecem como instâncias colegiadas pelas quais se organiza a gestão em saúde. Embora as formas de participação política dos Conselhos e conferências não estão claras na Constituição de 1988, a Lei do Sistema Único de Saúde (SUS) é a primeira que vai mostrar os instrumentos pelas quais a participação e o controle democrático vão se efetivar, seja pelas conferências como pelos Conselhos. No tema da Educação, artigo 206, inciso VI, o termo "gestão democrática" refere-se aos princípios do 
ensino, sendo um deles a "gestão democrática do ensino público na forma de lei". Consequentemente, a Lei de Diretrizes e Bases da Educação Nacional, LDB, (BRASIL, 1996) faz referência às formas de gestão democrática, via Conselhos Escolares, de acordo com o texto:

Art. 14. Os sistemas de ensino definirão as normas da gestão democrática do ensino público na educação básica, de acordo com as suas peculiaridades e conforme os seguintes princípios:

I - participação dos profissionais da educação na elaboração do projeto pedagógico da escola;

II - participação das comunidades escolar e local em conselhos escolares ou equivalentes. (BRASIL, 1996)

Já, nos anos 2000, o I Plano Nacional de Políticas para as Mulheres - PNPM (20132015), faz referência à necessidade de institucionalização de processos participativos com a criação de Conselhos e secretarias de defesa dos direitos das mulheres, que em uma das ações propõe a criação de estratégias de articulação entre os Conselhos de controle social do Sistema Único de Saúde (SUS) com o Conselho de direitos das mulheres, nas esferas municipais, estadual e federal (BRASIL, 2008).

De acordo com Luciana Tatagiba (2004), os Conselhos representam uma conquista democrática das instituições e estão presentes na maioria dos municípios do Brasil, organizados em nível federal, estadual e municipal nas áreas de educação, saúde, moradia, meio ambiente, transporte e cultura, dentre outros.

Ydeliz Coelho de Souza Sanches lembra que, com o processo de redemocratização que se institui no país, a gestão democrática também passa a ser adotada nas escolas:

Em redes de ensino estruturadas verticalmente, as propostas de instituição de Conselhos de Escola, de eleição para os dirigentes escolares, de possibilidade de fortalecimento da ação estudantil através de grêmios ou outras formas de livre associação, bem como dos pais e responsáveis, representavam possibilidade de democratizar a escola e proporcionar a construção de projetos com maior autonomia. (SANCHES, 2014, p. 84)

A proposta original dos Conselhos Gestores dos Centros Educacionais Unificados (CEUs) previu sua participação na elaboração e aprovação do Projeto Político Pedagógico do CEU, de forma a acompanhar e avaliar o plano de trabalho e as atividades desenvolvidas. Quem estaria responsável por essa atividade seria o colegiado do Conselho, formado pelo gestor e pelos diretores e coordenadores de cada unidade educacional ou núcleo de formação que compõe o Centro Educacional Unificado (CEU). A proposta original do Conselho Gestor instituía o colegiado de responsabilidade pelo bom funcionamento de suas unidades educacionais, de forma que os cidadãos pudessem se apropriar dos equipamentos, o que 
justifica que a composição inicial do Conselho Gestor deveria ser de maior participação de moradores da comunidade do entorno do Centro Educacional Unificado (CEU) do que de representantes das unidades educacionais. (DORIA; PEREZ, 2007).

Assim que foram inaugurados, em 2003, os CEUs passaram por um período sem a oficialização dos Conselhos Gestores, que estavam em fase de experimentação. O Decreto $n^{\circ}$ 45.559, de 30 de novembro de 2004, que aprovava o primeiro Regimento Padrão dos CEUs, passou a definir a composição tripartite do Conselho Gestor, formado por funcionários públicos, integrantes da comunidade e das organizações civis localizadas na própria comunidade do CEU. A mesma legislação previu em seu artigo 30, o Conselho Gestor como instância deliberativa e consultiva, tendo como responsabilidade a articulação com os colegiados e as instâncias do CEU.

Por integrar em um mesmo espaço físico e arquitetônico, complexo educacional, espaço de teatro, salão de ginástica, telecentro, pista de skate, centro comunitário, biblioteca, piscinas, quadras poliesportivas e uma padaria-escola, foi necessário o estabelecimento do Regimento Padrão para organizar diferentes sujeitos que transitam nesses vários espaços, a comunidade e as secretarias municipais. Desde a criação dos CEUs, foram aprovados quatro regimentos nos seguintes anos: 2004, 2005, 2006 e 2016.

Embora o Regimento Padrão tratasse da composição e da atribuição do Conselho Gestor, somente com a Lei n ${ }^{0}$ 14.662/08, em 03 de janeiro de 2008, pelo então prefeito Gilberto Kassab, que os Conselhos passam a ser criados legalmente, sendo institucionalizados. O decreto cria os Conselhos Gestores dos CEUs, e em seu segundo artigo define os Conselhos Gestores:

O Conselho Gestor do Centro de Educação Unificado é um colegiado com funções consultivas e deliberativas, cuja atuação está voltada para a defesa dos interesses e direitos das crianças, adolescentes e da população do entorno desses Centros, observando as finalidades e objetivos dos diversos órgãos da administração municipal”. (SÃO PAULO, 2008)

As atribuições do Conselho Gestor do CEU, descritas resumidamente, fazem parte da referida Lei de 2008 e do Regimento Padrão dos CEUs em vigência (Decreto no 57.478/16): I) discutir as diretrizes e prioridades das secretarias e órgãos que o integram e participar da criação de políticas públicas; II) definir as diretrizes, prioridades e metas anuais do CEU; III) analisar acompanhar os projetos do CEU; IV) avaliar o desempenho do $\mathrm{CEU}$; V) definir assuntos relativos à organização e funcionamento do CEU; VI) fixar critérios de uso do CEU; VII) propor a solução de problemas de ordem administrativa e pedagógica; VIII) decidir procedimento de integração com outros equipamentos públicos; IX) acompanhar atividades 
orçamentárias e decidir procedimentos na aplicação de verbas e X) desenvolver ações preventivas a violência institucional e social.

A composição paritária do Conselho Gestor do CEU visava garantir a participação da comunidade interna e externa do CEU. Pelo Regimento Padrão $n^{\circ}$ 57.478/16, os 15 representantes institucionais são distribuídos entre o gestor, diretoria do CEI, diretoria do Emei, diretoria do Emef, 2 membros do Núcleo de Esporte e Lazer, Cultura e Educação, 6 membros dos professores e trabalhadores do CEU e 3 representantes dos equipamentos do entorno do CEU. A representação da comunidade também de 15 membros está distribuída entre 5 estudantes do $\mathrm{CEU}$ ou fora dele, 5 familiares de estudantes do $\mathrm{CEU}$ e 5 membros de representantes da comunidade civil organizada.

Os/as candidatos/as ao cargo no Conselho Gestor devem escolher um segmento pelo qual irão concorrer à eleição, que será coordenada pela comissão organizadora eleitoral, como consta no artigo 37 do presente Regimento. O processo de escolha dos/as conselheiros/as se dará pelo voto em três candidaturas, por meio da aclamação em assembleia ou escrutínio, cujos eleitos/as serão considerados aqueles/as que obtiverem maior quantidade de votos nominais. Os mandatos dos/as conselheiros/as terão duração de dois anos, podendo esses participar de reeleição.

Embora não exista nenhuma exigência legal para ocupação do cargo de conselheiro/a do CEU, a não ser a necessidade de assinar o próprio nome ou vista da ata de reunião, como forma de validar o encontro, é importante destacar a exigência de disponibilidade de tempo, tendo em vista que as reuniões podem ocorrem em período matutino, vespertino ou noturno, com a possibilidade de ocorrer em dias da semana. Os encontros do Conselho Gestor do CEU pesquisado em análise ocorrem todas as segundas e quartas-feiras do mês, em horários mensalmente alternados pela manhã e de tarde. Sendo assim, o Regimento Padrão determina que as reuniões devem possuir calendário fixo para o conhecimento prévio dos participantes. Dessa forma, os participantes ficam cientes da exigência de tempo, antes de concorrerem ao cargo.

Como forma de incentivar a participação, o parágrafo sexto do artigo 36 do Regimento Padrão dos CEUs (Decreto ${ }^{\circ}$ 57.478/16) menciona a garantia de recebimento de certificação aos membros do Conselho Gestor, quando a presença se der em pelo menos $75 \%$ das reuniões. A mesma legislação garante a cada membro titular do Conselho a figura de um suplente para substituição em caso de ausência ou desligamento do colegiado, assim como usa do mecanismo 
da punição com a destituição do cargo do titular, quando da ausência em mais de duas reuniões consecutivas sem justificativas.

O exercício de conselheiro/a não está condicionado a nenhuma forma de remuneração, sendo atuação de caráter voluntária. Outros/s membros/as da comunidade e representantes institucionais que não tenham sido eleitos/as podem participar das reuniões, sem direito a voto, somente a voz.

\subsubsection{A ocupação de cargos no Conselho Gestor do CEU}

O gestor é considerado membro nato do Conselho Gestor do CEU, sendo responsável pelo colegiado e pela coordenação do Colegiado de Integração, bem como pela própria gestão do Centro Educacional Unificado. O gestor conta com uma equipe de Núcleo de Apoio Administrativo, responsável pela manutenção do cadastro de usuários/as e matriculados/as nas atividades do CEU, o serviço de atendimento ao público, assim como a tarefa de manutenção de indicadores de metas no Projeto Político-Educacional anual do CEU, o controle de frequência e gerenciamento funcional dos trabalhadores. Cabe também a tarefa de administrativa gerais e os encaminhamentos propostos pelo gestor, observados os limites legais.

A assinatura da Portaria n ${ }^{\circ}$ 2.212, de 26 de março de 2003, pela Secretaria Municipal de Educação (SME), deu o pontapé inicial na instituição da função de gestor dos CEUs, meses antes da inauguração do primeiro CEU, em 1 de agosto. Conforme artigo $2^{\circ}$ da referida Portaria, a função de Gestor Geral dos CEUs estaria ligada ao exercício de liderança, articulação e coordenação das ações e projetos desenvolvidos nas unidades que fazem parte dos CEUs, a partir do princípio de gestão de participação e do compartilhamento.

Em 03 de dezembro de 2004, a Portaria $n^{0} 5.542$ passou a dispor sobre o processo eletivo do Conselho Gestor nos CEUs. Em seu formato original, para a composição do cargo da gestão dos CEUs, após chamada pública (Portaria SME n 2.212, de 26 de março de 2003) de inscritos/as, os representantes das comunidades que receberiam os recém-construídos equipamentos educacionais escolheram via votação três candidatos/as a gestor/a que tiveram relação dos nomes encaminhada para a seleção da SME.

O pré-requisito exigido dos/as candidatos/as que concorreram ao cargo de gestor/a do CEU, naquele momento, era a experiência mínima como educador/a na Rede Municipal de Educação por três anos, além da apresentação de uma proposta de gestão democrática para o CEU. Antes de serem escolhidos, os/as candidatos/as de cada CEU que compunham lista tríplice passaram por formação de 40 horas. A partir da observação do desempenho dos/as 
candidatos/as no processo formativo, ocorreu a seleção dos/as primeiros/as gestores/as dos 21 CEUs inaugurados, em 2003 e 2004. (DORIA; PEREZ, 2007)

Inicialmente, o Instituto Paulo Freire (IPF) ficou responsável pela prestação de serviço de assessoria pedagógica aos Conselhos provisórios dos CEUs, com a tarefa de conferir capacitação presencial e à distância dos gestores na organização dos Conselhos, na discussão de um Regimento Padrão para os CEUs, fundamentada, principalmente, em uma concepção de gestão democrática. Exceto essa formação inicial, que ocorreu com os primeiros gestores dos CEUs, quando da inauguração em 2003 e 2004, e no Seminário Nacional dos CEUs, ocorrido de 02 a 03 de dezembro de 2014, em Brasília, não consta na literatura e na legislação nenhum outro momento formativo pela qual os gestores e os/as membros/as do Conselho tenham passado.

De 2003 a 2004, não era pré-requisito para assumir o cargo de gestor dos CEUs, necessariamente, possuir vinculação partidária local, já que uma das etapas anteriores da indicação do cargo pelo Secretário Municipal de Educação passava pela votação junto à comunidade. Ou seja, ainda que o Secretário Municipal fizesse a indicação dos gestores dos CEUs, a partir da lista tríplice de eleitos pela comunidade, a escolha passava por uma etapa de votação, não deixando de ser de caráter democrático.

Todavia, diferentemente do processo realizado em 2003 e 2004, a nomeação do gestor do CEU, a partir de 2005, passou a ser designada pelo executivo municipal, que por meio da Portaria $n^{0} 7.356 / 05$ detinha amplo poder de escolha, excluído o rito da eleição junto à comunidade, o que ampliava o caráter político na nomeação. O Decreto $n^{0}$ 57.478/16 mantém a nomeação do gestor pelo executivo municipal.

\subsubsection{As mudanças nas esferas participativas dos CEUS}

Em sua origem, os CEUs possuíam somente duas instâncias de participação democrática, sendo o Conselho Gestor, de caráter representativo e a Assembleia Geral, como instância de participação direta (SÃO PAULO, 2004). Em 2005, o Decreto no 45.559/04, que aprovava o Regimento Padrão dos CEUs, foi revogado pelo Decreto n ${ }^{0} 46.701$. Então, a Portaria $\mathrm{n}^{\mathrm{o}} 7.356$, de 01 de dezembro de 2005, passa a regulamentar o novo Regimento Padrão dos CEUs, que foi modificado, novamente, em 05 de dezembro de 2006, por meio da Portaria $\mathrm{n}^{\mathrm{o}}$ 4.672. Diante das alterações legais (SÃO PAULO, 2004; 2005 e 2006), no período 2004-2006, Sanches (2014) observa a manutenção da estrutura organizacional do Conselho Gestor, do Colegiado de Integração e as Comissões Temáticas do CEU, outros espaços de participação dos 
CEUs. Por outro lado, a Assembleia Geral e as Assembleias Setoriais foram suprimidas pela Portaria $n^{0} 7.356 / 05$, enquanto a Associação de Pais e Mestres e Servidores, Usuários e Amigos do CEU (Apmsuac) foi incorporada no novo regimento (Portaria $\left.n^{0} 7.356 / 05\right)$. A Associação de Pais, Mestres e Servidores, Usuários e Amigos do Centro Educacional Unificado (Apmsuac) é uma instituição auxiliar da gestão do CEU, representativa dos pais, mães ou responsáveis dos alunos matriculados, do corpo docente, dos demais usuários e amigos do CEU, sendo vinculada ao Conselho Gestor. Associação de Pais, Mestres e Servidores, Usuários e Amigos do CEU (Apmsuac) tem por finalidade participar na colaboração do aprimoramento do processo educacional, assistência escolar e da integração entre a unidade educacional com a comunidade.

No que se refere ao Conselho Gestor, observamos que o primeiro Regimento Padrão dos CEUs de 2004 (SÃO PAULO, 2004) previa a composição tripartite do fórum. A normativa de 2004 assegurava a composição mínima de 39 e o máximo de 63 membros, ao passo que a Portaria seguinte, $\mathrm{n}^{\mathrm{o}} 4.672$, de 2006, reduz o mínimo de 20 e o máximo de 40 membros. Tanto a legislação de $2005\left(n^{0}\right.$ 7.356) quanto de $2006\left(n^{\circ}\right.$ 4.672) passam a prever a composição de $50 \%$ de membros da comunidade, entendida por sua composição de funcionários das escolas do entorno, pais e alunos das escolas do entorno e das do CEU, além de membros da sociedade civil da região do CEU (SANCHES, 2014). Considerando a alteração descrita, notamos que a legislação ao reduzir a composição mínima e máxima de participantes diminui, também, seu espaço e sua representatividade, porque deixa de captar com precisão as distintas demandas dos integrantes e sua heterogeneidade.

Sanches (2014) observa que, ao contrário do Primeiro Regimento Padrão dos CEUs (SÃO PAULO, 2004), que mantinha as reuniões do colegiado mensais, as Portarias $\mathrm{n}^{\mathrm{o}} 7.356 / 05$ e ${ }^{\circ}$ 4.672/06 alteram a periodicidade das reuniões do Conselho Gestor, passando para encontros bimestrais. Somente com o Decreto $\mathrm{n}^{0} 50.738$, de 15 de julho de 2009, que regulamenta a Lei $n^{0} 14.662$, de 3 de janeiro de 2008, que dispõe sobre a criação dos Conselhos Gestores dos CEUs, que passa a determinar que as reuniões do colegiado retornem à frequência mensal.

Com as reuniões bimestrais, há uma diminuição da frequência dos encontros do acompanhamento dos/as conselheiros/as ao equipamento público e um aumento da distância de acesso ao conhecimento minucioso das demandas dos representantes, para que a comunidade possa obter melhorias.

Sanches (2014) nota também o retrocesso legal nas Portarias no 7.356/05 e nº 4.672/06, com a eliminação da competência do Conselho Gestor de manifestar opinião sobre convênios e contratos, assim como tratar da utilização dos recursos, em comparação à legislação de 2004, 
que em seu artigo 44 e inciso IV tratavam de: "IV - opinar sobre convênios e contratos de interesse específico do CEU com organizações públicas e privadas” (SÃO PAULO, 2016).

O Decreto $n^{\circ} 50.738$, de 15 de julho de 2009, que vigorou por sete anos (revogado pelo Decreto $^{0} 57.478 / 16$ ), regulamentou a Lei $n^{\circ} 14.662$, de 3 de janeiro de 2008, que dispõe sobre a criação dos Conselhos Gestores dos CEUs. Quando comparamos as atribuições do Conselho Gestor nas normativas de 2009 e de 2016, percebemos pouca diferença. A normativa de 2016 limita-se somente ao período dos finais de semana a possibilidade para que o Conselho Gestor possa "fixar critérios de cessão, uso e preservação das instalações do CEU" e não inclui os feriados e recessos como a legislação de 2009 previa. (SÃO PAULO, 2016). Ao passo que a normativa de 2016 acrescenta mais uma função do Conselho Gestor, no inciso XI, que é a tarefa de "aprovar e participar da elaboração do Regimento Interno do CEU”. Com essa nova atribuição, o Conselho Gestor passa a ter maior poder de decisão nas determinações da administração dos CEUs, já que o Regimento Padrão é o marco referencial que viabiliza o gerenciamento cotidiano dos equipamentos, como base no princípio da gestão democrática.

A versão atualizada do Regimento Padrão n ${ }^{0}$ 57.478/16 apresenta alguns avanços ao ampliar na redação da lei (artigo 36, inciso II) diversos segmentos sociais representantes da comunidade do Conselho Gestor: "do meio ambiente e sustentabilidade, de direitos humanos, de idosos, de pessoa com deficiência, de diversidades culturais, de movimentos etnicorraciais (negro, indígena e imigrante), gênero e LGBT, educacionais - movimentos por educação, da cultura periférica, esportivos, economia solidária, religiosos e entidades empresariais". (SÃO PAULO, 2016)

Ao contrário dos regimentos anteriores, o destaque da normativa de 2016 é a enunciação de representação de segmentos sociais do Conselho Gestor. Mesmo que nas legislações anteriores esses grupos sociais também estivessem tacitamente contemplados, a descrição em normativa expressa o reconhecimento pelo Estado da existência de segmentos sociais vulneráveis, que historicamente estiveram à margem. Dessa forma, o presente estudo, ao versar sobre o protagonismo civil das mulheres no Conselho Gestor do CEU, ressalta o recorte de raça/etnia, sobretudo o atributo etário das conselheiras, tendo em vista a predominância do grupo de mulheres idosas entre as entrevistadas na pesquisa. 



\section{OS CAMINHOS DA PESQUISA}

\subsection{A ESCOLHA DO CEU}

Para a escolha do Centro Educacional Unificado (CEU) foram utilizados alguns critérios importantes: (1) Conselho Gestor mais ativo e representativo de mulheres; (2) a proximidade do local de moradia da pesquisadora e (3) o alto grau de vulnerabilidade social da população local.

A pesquisa foi realizada com abordagem qualitativa e a metodologia proposta foi a realização de entrevistas, posto que esses procedimentos permitiram fazer um estudo de um Centro Educacional Unificado (CEU) da cidade de São Paulo, mas com foco específico nas experiências de participação de mulheres em seu Conselho Gestor, com a finalidade de refletir sobre como a participação influencia a vida das mulheres que vivem no entorno do equipamento público educacional na periferia e as consequências da participação no Conselho Gestor em suas vidas. Antes da entrevista, eu solicitava às participantes da pesquisa a leitura e assinatura do Termo de Consentimento Livre e Esclarecido (APÊNDICE 3). No roteiro de entrevistas aplicado individualmente a todas as mulheres, eu contemplava perguntas gerais sobre os antecedentes no cargo do Conselho, trajetória de participação política, os desafios da participação feminina no Conselho Gestor, a forma de conciliação dos afazeres domésticos com a atividade no Conselho, as formas de lazer, dentre outras. Após as entrevistas, apliquei um questionário individual com questões sobre atributos pessoais, condição familiar, afazeres domésticos e trabalho remunerado (APÊNDICE 5).

O passo seguinte, após definida região da pesquisa, foi a consulta realizada à Diretoria Regional de Educação da Secretaria Municipal de Educação de São Paulo (DRE) com objetivo da obtenção de indicação de Centro Educacional Unificado (CEU) que se aproximasse dos critérios elencados. Em conversa feita com dirigente da Secretaria Municipal de Educação de São Paulo, obtive as indicações de dois Centros Educacionais que mais se aproximavam dos critérios estabelecidos para a pesquisa, e como já mencionado, optei pela escolha de um único CEU.

O CEU escolhido iniciou suas atividades em 2004. Conforme Doria e Perez (2007), a arquitetura deste CEU se diferencia dos outros, pois a construção foi feita em uma área menor e de alto declive. Como não foi possível serem construídos os três blocos padrão do 
CEU (didático, cultural/esportivo e o redondo), foi feita a junção do bloco cultural/esportivo em um único prédio vertical, ficando separado o prédio redondo. Devido à declividade do terreno, existem dois portões de acesso ao prédio.

A escolha dos locais de construção dos Centros Educacionais Unificados foi determinada pela ausência do poder público (PADILHA; SILVA, 2004) que por meio da metodologia de análise de incidência de desigualdades econômicas e sociais entre os territórios da cidade de São Paulo desenvolveu-se o Mapa da Exclusão/Inclusão Social da Cidade de São Paulo.

$\mathrm{O}$ distrito no qual se localiza o CEU pesquisado possui população total de cerca de 200 mil habitantes, observado um crescimento de $10 \%$ no período pesquisado.

O bairro possuía, em 2010, o IDH (Índice de Desenvolvimento Humano) médio, com valor de 0,791 e, de acordo com Índice de Vulnerabilidade Social (IVS), de 2017, da Nossa São Paulo (REDE NOSSA SÃO PAULO, 2017), o distrito apresentava índice elevado entre $15 \%$ a $29,9 \%$ da população em situação de alta ou muito alta vulnerabilidade.

Já do ponto de vista socioeconômico, no período de 2013 a 2016, a quantidade de famílias em situação de extrema pobreza, ou seja, famílias que possuíam até 1/4 do salário mínimo, quase dobrou, passando de 7.720 famílias para 12.999 famílias.

O distrito possuía 1,48 equipamentos públicos de cultura por mil habitantes, em 2016. Esse índice, desde 2010, tem apresentado queda, sendo que em 2010 era de 1,62, de acordo com dados da ObservaSampa, plataforma virtual de indicadores da Prefeitura Municipal de São Paulo.

$\mathrm{Na}$ análise dos indicadores de gênero, o distrito apresentava um percentual entre $0 \%$ a 5\% mais de mulheres em relação aos homens, segundo estatísticas da Rede Nossa São Paulo para o ano de 2017. Entretanto, os dados de homens (486) beneficiários do Benefício de Prestação Continuada (BPC) entre as pessoas com deficiência é maior do que o de mulheres (462) em 2014.

Quando analisados os dados de educação, sobre a proporção de crianças atendidas nas creches das redes públicas (municipal, municipal conveniada, estadual ou federal) no distrito, é possível perceber um aumento, no período de 2010 (29,5\%) a 2017 (60,4\%).

Em visita ao Centro Educacional Unificado escolhido, em 13 de dezembro de 2016, o gestor, ainda da administração Haddad, colocou-se à disposição para conversa e acesso 
ao livro das atas das reuniões ${ }^{5}$ do Conselho, além das listas de presença; listas dos resultados das eleições de 2014 e 2016; edital de convocação de eleição de 2014; fichas de inscrição dos/as candidatos/as de 2014 e 2016; panfletos de chamadas das eleições de 2014 e 2016; editais de convocações de reuniões extraordinárias 2014 e 2015; resultado de lista de condutores para a retirada do convite sobre reunião ao Conselho Gestor ${ }^{6}$; ofício de solicitação à Companhia de Engenharia e Tráfego (CET) de novas sinalizações para as vagas dos veículos de transporte escolar; e sobre a decisão pública tomada em reunião acerca do uso do estacionamento. As atas do Conselho Gestor são registros oficiais das reuniões que constam data, participantes, temas tratados, encaminhamentos $\mathrm{e}$ questionamentos levantados, sendo documento assinado pelos presentes.

Foi registrada toda documentação disponível além de gravação de conversa. Durante a visita, o gestor que fez o atendimento, também apresentou alguns dos/as funcionários/as do equipamento educacional que permaneceriam em seus cargos caso houvesse mudança na gestão, com repasse do contato telefônico deles. Esse fator foi muito importante para a decisão de escolha do campo, já que, além da indicação da DRE, foi estabelecida relação entre a equipe de funcionários/as, durante a visita exploratória, o que garantia a continuidade de contatos futuros para a pesquisa. Embora tenha sido feito o convite do gestor para participação da última reunião do Conselho em 2016, não foi possível, em razão de conflito de agenda de viagem de trabalho.

O CEU escolhido mostrou-se mais receptivo que o outro CEU indicado, com um corpo de funcionários permanente, assim, caso houvesse mudança de gestão, não haveria prejuízos à continuidade da pesquisa.

As atas das reuniões do Conselho Gestor consultadas no CEU durante a pesquisa correspondem ao período da gestão do prefeito Fernando Haddad (2013-2016), portanto não correspondem ao período de gestão da atual gestora. Os principais temas abordados nas respectivas atas do Conselho Gestor do CEU no período compreendido eram: 1) eleição de presidente do Conselho; 2) datas e horários das reuniões previstas no calendário do semestre; 3) informe de assembleia na unidade educacional do Emef para seleção de representante discente do CG; 4) calendário das dedetizações no CEU; 5) local e data do Baile da Melhor Idade; 6) aulas esportivas e do teatro; 7) circulação de pessoas no CEU;

\footnotetext{
${ }^{5}$ Registro das reuniões do Conselho Gestor dos dias 11/6/14; 17/7/14; 4/8/14; 11/8/14; 8/9/14; 13/11/14; 03/3/15; 13/4/15; 25/5/15; 8/6/15; 18/6/15; 06/7/15; 01/8/15; 14/9/15; 19/10/15;09/11/15; 16/12/15;15/02/16; 14/3/16 e 09/5/16.

${ }^{6}$ Refere-se ao convite de participação a reunião do Conselho Gestor aos condutores escolares, pessoas físicas e jurídicas, credenciadas à prestação de serviços no âmbito do Programa de Transporte Escolar Municipal Gratuito - Vai e Volta, no Município de São Paulo.
} 
18) limpeza; 19) segurança dos portões; 10) terceirizadas; 11) desrespeito das crianças aos funcionários de segurança; 12) organização das Festas da Cultura Brasileira, Virada Cultural, Dia do Professor e aniversário do bairro e do CEU; 13) Semana de Hip Hop; 14) eventos; 15) organização dos perueiros prestadores de serviço do CEU; 16) preocupação com os alunos que ficam à espera do transporte escolar; 17) lotação do transporte escolar; 18) remarcação de vagas das ruas ao transporte escolar; 19) informes sobre a sala de Telecentro; 20) início de funcionamento da Rede UniCEU; 21) atividades de reparo de vazamento hidráulico, telhado descoberto, calçadas; 22) acesso ao CEU; 23) entulho, portas danificadas, redes e traves da quadra; 24) falta de água do prédio e 25) procedimento em caso de acidentes nas dependências. Observei que a discussão desses temas sempre é recorrente, independente de qual período do ano.

Foram adotados dois critérios na seleção das atas utilizadas na análise da pesquisa. Primeiramente aquelas que mais se destacavam em diferentes momentos do período analisado (2014-2016) , cujo conteúdo apresentavam mais elementos para a análise sobre os temas relevantes para a organização do trabalho no CEU. No segundo momento, selecionei as atas que mais se alinhavam ao assunto apontado pelas conselheiras. As atas mostram alguns momentos na dinâmica das reuniões cujos participantes questionam e propõem ações. Além da figura do/a gestor/a e das mulheres conselheiras entrevistadas, os/as demais participantes do Conselho Gestor são representações da comunidade, gestores do CEI, Emei, Emef, coordenação de esporte e tutores da rede UniCEU dentre outros, de presença rotativa.

Da leitura geral das atas, depreendi que a reunião se inicia com a apresentação dos presentes e com a leitura da ata da reunião anterior. Após a apresentação dos temas que irão ser tratados no Conselho, é iniciada a discussão de cada item da pauta. Caso os membros do colegiado queiram acrescentar outras pautas na reunião, o gestor solicita essa incorporação de temas no início da reunião.

A partir do material coletado, tanto em formato de gravação de áudio quanto de anotações das conversas e os registros fotográficos das atas, elaborei o roteiro de entrevista com as conselheiras representantes da comunidade do CEU selecionado, tendo em vista as impressões da primeira inserção no campo.

A segunda etapa de trabalho de campo junto ao CEU, realizada no período de 25 de abril de 2018 a 26 de junho de 2018, compreendeu a realização de uma conversa de apresentação e seis entrevistas. Em reunião com atual gestora, foi feito o agendamento para a conversa coletiva com duas conselheiras mais experientes do colegiado que ocorreu em 
25 de abril de 2018. As entrevistas individuais ocorreram nos seguintes dias: 02/5; 03/5; $18 / 5 ; 21 / 5 ; 05 / 6$ e 26/6. Ao todo, foram mais de 10 horas de entrevistas, que correspondem a 6 entrevistas, concentradas entre abril e junho de 2018.

Para o diálogo de apresentação, a atual gestora do Centro Educacional Unificado (CEU) fez o agendamento para uma conversa com as duas conselheiras mais experientes do colegiado. Com a data de reunião confirmada, dia 25 de abril de 2018, o encontro ocorreu na sala de reunião do Conselho Gestor no CEU. A gestora intermediou minha apresentação para as duas conselheiras e, na sequência, retirou-se da sala. A reunião com as duas mulheres conselheiras teve o propósito de promover o encontro pessoalmente, informar sobre a pesquisa, reforçar o convite para que outras conselheiras que pudessem ser indicadas aderissem às entrevistas, com a preocupação de dirimir possíveis dúvidas sobre o sigilo e, também, deixá-las à vontade para quaisquer indagações.

As duas mulheres que participaram dessa etapa foram as conselheiras mais antigas do Centro Educacional Unificado e que ainda permanecem no colegiado. Elas foram muito receptivas, inclusive uma delas relatou já ter participado de outra pesquisa acadêmica (JUSTINIANO, 2014) no passado sobre o CEU.

Foram agendadas as entrevistas individuais com essas duas conselheiras. Informei à gestora as datas que retornaria ao CEU para aplicar as entrevistas iniciais, contando com o apoio dela também na utilização do espaço do CEU para as entrevistas. Na ocasião, aproveitei para trocar contato telefônico e e-mail com as duas conselheiras, caso houvesse algum imprevisto das partes.

O intuito inicial era reunir todas as participantes do Conselho Gestor de vigência de 2014-2016 para uma única apresentação da pesquisa para todas. Eu havia pensado em organizar uma roda de conversa informal, de forma a extrair informações para a construção do roteiro de entrevistas, a ser aplicado em um segundo momento da pesquisa. Contudo, em razão do exíguo tempo, optei pela proposta de roda de conversa com as conselheiras mais experientes do colegiado, o que se mostrou positiva com a adesão posterior de outras conselheiras. Acredito que o reconhecimento da experiência participativa do Conselho Gestor legitimou a adesão de outras mulheres na pesquisa.

Embora o período de abrangência da pesquisa contemple a gestão do prefeito Fernando Haddad (2013-2016), solicitei inicialmente que as integrantes relatassem vivências do período de 2014 a 2016. Contudo, as experiências relatadas extrapolam esse período, já que algumas mulheres trouxeram relatos de sua experiência ao longo de muitos anos no Conselho Gestor. Algumas mulheres que participaram do Conselho no período de 
2014 a 2016 eram as mesmas participantes de outros períodos. Por essa razão, optei por incluir as mulheres que participam do Conselho Gestor desde 2014 até a atual gestão (2018).

Com o objetivo de compreender as motivações, as experiências e os aprendizados derivados da participação de mulheres, no Conselho Gestor foram feitas as entrevistas no próprio Centro junto às mulheres conselheiras e ex-conselheiras do colegiado. Também foi realizada entrevista com a gestora do Conselho do referido Centro Educacional Unificado, como forma de ajudar a compreender o contexto do CEU escolhido. Essa gestora havia acabado de assumir a gestão e, por isso, sua entrevista funcionou apenas como apoio, não sendo incorporada à análise dos demais relatos das conselheiras entrevistadas, a fim de assegurar a manutenção de sigilo.

As entrevistas com as mulheres mais experientes no Conselho, porém, foram caracterizadas por um discurso de senso comum, com duração de aproximadamente uma hora para cada. A impressão é de que as respostas foram curtas e objetivas, sem uma problematização e reflexão aprofundada dos temas, talvez devido à vivência e experiência em outros espaços participativos.

Já as mulheres que foram indicadas pelas primeiras entrevistadas depositaram maior confiança em problematizar os temas, em comparação com as mulheres mais experientes no Conselho, dedicando o dobro ou mais de tempo nas conversas. No relato dessas mulheres, foi possível perceber a existência de tensões e conflitos com a gestão, ocultados nos relatos das duas conselheiras de mais idade.

Em média, as entrevistas duraram uma hora e trinta e cinco minutos, chegando, às vezes, a ultrapassar duas horas. Em uma das entrevistas, a duração ocorreu em uma manhã inteira, sendo interrompida pelo compromisso da tarefa de preparo do almoço pela conselheira entrevistada.

Para a análise, foram utilizadas as 05 entrevistas realizadas. Conforme já mencionado, a entrevista com a atual gestora do CEU não foi incorporada na análise final, mas contribuiu para a compreensão do contexto. A primeira abordagem se deu ao telefone com as conselheiras, e consistiu em uma apresentação minha, com breves informações sobre quem eu era, onde estudava e morava. O contato com a gestora se deu presencialmente, por e-mail e por telefone. À medida que eram realizadas as entrevistas com as conselheiras no equipamento, eram feitas breves interlocuções com a gestora. Essa forma de abordagem permitiu o estabelecimento de laços de confiança com ela, o que 
facilitou a comunicação e maior familiaridade em solicitar sala para as entrevistas e indicação de outras conselheiras para novas entrevistas.

Empreguei um roteiro de entrevistas semiestruturadas, individual, gravador e um questionário socioeconômico, com o intuito de captar informações de atributos pessoais e socioeconômicos da entrevistada.

Com exceção da gestora do Centro Educacional Unificado, todas as mulheres entrevistadas e que responderam ao questionário eram donas de casa, frequentadoras do Centro Educacional Unificado e moradoras do entorno do equipamento público, o que facilitou os encontros no CEU, ocorridos no período da manhã. A maioria das entrevistas individuais ocorreu após as usuárias frequentarem aula de ginástica no próprio Centro Educacional Unificado (CEU), ou após as mães deixarem suas crianças em atividades escolares no Centro Educacional Unificado (CEU). Com os filhos/as acolhidos/as, as entrevistas ocorreram sem preocupações extras. Por isso, todas as mulheres entrevistadas pediram que o horário da entrevista não fosse logo nas primeiras horas do amanhecer, pois estariam em aula de ginástica no CEU ou atarefada no encaminhando dos filhos para a aula.

Todas as conversas foram realizadas no Centro Educacional Unificado, no período de 29 de março até 26 de junho de 2018, tanto na sala da gestora, como na sala de reunião e na sala multimeios na Biblioteca do CEU. As conversas com a gestora do CEU foram realizadas em sua própria sala, enquanto as conversas com as conselheiras ocorreram na sala de reunião e na biblioteca do Centro Educacional. Como as paredes da sala de reunião não são feitas de alvenaria, mas de placas de divisórias para escritório, fiquei com receio de que os depoimentos das mulheres pudessem ser ouvidos pelos/as funcionários/as do lado de fora da sala de reunião, comprometendo a privacidade. Desse modo, as duas últimas entrevistas foram feitas na Biblioteca do Centro Educacional Unificado (CEU). Durante a metade da entrevista com uma das conselheiras, houve a necessidade de mudança para o espaço da biblioteca, para a continuidade, pois a sala em que ocorria a entrevista havia sido reservada para outra reunião.

Ainda no que se refere aos espaços onde foram tomadas as entrevistas no Centro Educacional Unificado (CEU), a sala da gestão também possui placas de divisória para escritório, dividindo com o restante do espaço composto por mesas-baia dos/as funcionários/as. Algumas entrevistas foram feitas na biblioteca, cujo espaço amplo e vazio possibilitou a realização das entrevistas e sem interferência para o áudio das gravações. No local, havia uma funcionária que permanecia a uma distância que não permitia ouvir a conversa, assim como uma ou duas alunas concentradas que ali realizavam tarefas 
escolares. A sala de reunião da gestão possui uma mesa ao centro e se localiza ao lado da sala da gestora do Centro Educacional, separado por uma placa de divisória para escritório e um vidro onde é possível ver desde a sala da gestão até a porta de entrada do espaço onde se localizam os funcionários. Por causa do calor, em algumas entrevistas, o ventilador de teto foi ligado, assim como utilizado o bebedouro de água. Sobre a mesa, permaneceram durante a entrevista, discretamente, o gravador, celular e tablet, todos aparelhos garantindo a captura do áudio, assim como as folhas de sulfite, caneta, caderno de campo para as anotações importantes durante a conversa e copos de água.

Vale ressaltar que os funcionários da área administrativa da gestão do CEU, que trabalhavam do lado externo da sala da reunião e da sala da gestora eram, predominantemente, mulheres, com exceção de dois homens, o que revela que a presença feminina na área educacional não se limita ao corpo docente. Até mesmo o serviço de segurança contratado na porta de entrada do Centro Educacional Unificado é feito predominantemente por mulher. Nas primeiras visitas ao CEU, identifiquei-me para as seguranças terceirizadas, informando qual o local onde iria, a fim de não trazer nenhum problema, de ordem disciplinar, que pudesse comprometer as futuras entradas em campo. Entretanto, nas entrevistas finais, já reconhecida, eu entrava no prédio sem identificação, somente com um cumprimento à segurança e aos funcionários. Normalmente, o ponto de encontro com as mulheres entrevistadas, no dia da entrevista, localizava-se embaixo do quiosque do Centro Educacional Unificado, ou em frente a própria sala da gestão.

\subsection{SOBRE AS MULHERES ENTREVISTADAS}

Durante as entrevistas, as mulheres puderam acrescentar outros temas e observações que julgaram necessários, possibilitando, assim, o mapeamento das percepções, entre as conselheiras, sobre a participação da mulher no Conselho Gestor do Centro Educacional Unificado (CEU).

Foram realizadas, no total, cinco entrevistas com mulheres conselheiras, exconselheiras e uma conversa com a atual gestora do Centro Educacional, todas moradoras da região noroeste da cidade de São Paulo. Mesmo não considerando na análise total das conselheiras a entrevista da atual gestora, as informações pessoais dela estão incluídas nesse item.

Os critérios de escolhas para as entrevistas no Centro Educacional Unificado (CEU) foram: 1) ser mulher e 2) estar na função ou já ter exercido o cargo de conselheira, pelo menos, de 2014 até 2018. 
As entrevistas foram realizadas, entre maio e junho de 2018, com mulheres que ocupam ou ocuparam o cargo de conselheiras, pelo menos, desde o ano de 2014, tanto na gestão do prefeito João Doria e Bruno Covas, do Partido da Social Democracia Brasileira (PSDB), como na gestão do prefeito Fernando Haddad, do Partido dos Trabalhadores (PT). O objetivo das entrevistas é compreender como a participação influencia a vida das mulheres no espaço do Conselho Gestor do Centro Educacional Unificado (CEU).

Ao comparar os atributos pessoais de escolaridade das mulheres conselheiras, exconselheiras e atual gestora, percebi três grupos distintos entre as entrevistadas: 1) duas mulheres com nível de escolaridade do antigo ensino primário; 2) duas mulheres com ensino médio completo e 3 ) duas mulheres com superior cursando ou completo com pósgraduação.

No atributo pessoal de raça/etnia das conselheiras, das cinco entrevistadas mais a atual gestora, quatro se autodeclararam "brancas", enquanto uma disse ter "todas" as cores e outra se autodeclarou "negra".

Ao observar a faixa etária das cinco mulheres, percebi que a média é de 52,6 anos. A mais jovem do grupo entrevistado possui 37 anos, e as duas conselheiras de mais idade, ambas possuem 61 anos. Quando observei o estado de origem das mulheres conselheiras do Centro Educacional, vi que quase todas são oriundas do estado de São Paulo; uma das conselheiras nasceu na Bahia, em Juazeiro.

A relação das mulheres com o bairro foi um ponto em comum para todas as entrevistadas, já que todas residem no bairro, há, pelo menos 17 anos, isso revela possuírem vínculos de longa data no território. A moradora mais antiga mora há 41 anos no bairro. A religiosidade foi outro ponto de destaque, pois, das cinco entrevistadas, uma não quis declarar sua religião, enquanto as outras quatro declararam ser católicas.

É importante destacar a condição de atividade do grupo de mulheres entrevistadas em relação à escolaridade e à raça/etnia. Das duas que possuem ou cursam o ensino superior, somente a mulher que se autodeclarou branca é economicamente ativa, ao passo que a outra, se autodeclarou ter todas as cores. Das duas mulheres com ensino médio completo, a mulher que se autodeclarou negra, acumula funções de dona de casa e autônoma, sendo considerada como economicamente ativa. A outra conselheira, com ensino médio, é economicamente inativa, já que exerce exclusivamente atividade de dona de casa, se autodeclarou ser branca. As outras duas conselheiras de maior idade, embora possuam menor escolaridade, são aposentadas e se autodeclararam brancas. 
$\mathrm{Na}$ análise da composição familiar, todas as mulheres entrevistadas viviam com uma pessoa ou mais no domicílio, no período que ocupavam o cargo de conselheiras do Centro Educacional Unificado, assim como todas tinham filhos. Somente uma das entrevistadas possuía filho/a menor de 10 anos. A pergunta no questionário visava descobrir se havia menores de dez anos que residiam em casa, indicando maior dedicação das mulheres no trabalho de cuidado dos menores, seja de filhos ou netos.

O questionário abordou sobre a existência de pessoas idosas ou com deficiência no domicílio, com o objetivo de captar o dispêndio de trabalho doméstico desse grupo, entretanto nenhuma das mulheres declarou conviver na residência com pessoas com essas condições.

O bloco de questões sobre a responsabilidade dos afazeres domésticos no lar teve como objetivos investigar as formas de organização familiar e o papel da mulher na esfera privada, quem é o/a responsável pelas decisões familiares. Quatro das seis entrevistadas são responsáveis pelos afazeres domésticos, seja dividindo com outros membros do domicílio ou como únicas responsáveis no lar; as duas mulheres de mais idade do Conselho Gestor, não. Ambas responderam serem as únicas responsáveis pelo trabalho doméstico em seus domicílios, embora existam outros membros residindo junto. A única conselheira que tem um dos filhos menores de idade mencionou que divide com todos seus filhos os afazeres, entretanto seu esposo não participa dessa divisão de trabalho doméstico. Embora as outras conselheiras respondessem dividir com os homens da casa o trabalho doméstico, devemos considerar, pelas entrevistas, que essa divisão do trabalho não é realizada de forma equitativa para todas.

No bloco de perguntas relacionado ao trabalho remunerado, a maioria das mulheres afirmaram não trabalhar fora do domicílio quando exerciam o cargo no Conselho Gestor do Centro Educacional. Com exceção da atual gestora, que já exerce trabalho remunerado no próprio Centro Educacional, somente uma mulher disse ter exercido o trabalho de autônoma, como trabalho principal, quando atuava no Conselho. E a frequência desse trabalho, durante a semana, era exercido de duas a três vezes, somente.

Quando observo o bloco de questões relacionado aos rendimentos e situação de moradia, a maioria das mulheres afirmou ser a responsável pelo orçamento do seu grupo familiar. Somente duas relataram que os maridos são os responsáveis pelo orçamento familiar.

Nenhuma das mulheres entrevistadas recebia benefícios de programas de transferência de renda, quando elas exerciam o cargo no Conselho Gestor do Centro 
Educacional (CEU), programas que normalmente têm como público-alvo as mulheres como beneficiárias.

A seguir, apresento um pequeno perfil das conselheiras entrevistadas, com exceção da atual gestora: 
Quadro das conselheiras do CEU

\begin{tabular}{|c|c|c|c|c|c|}
\hline Nome $^{7}$ & Mariana & Lilian & Nair & Mercedes & Renata \\
\hline Idade & 61 & 61 & 55 & 53 & 37 \\
\hline Etnia & Branca & Branca & Todas & Negra & Branca \\
\hline Estado civil & Solteira & Divorciada & Casada & Casada & Casada \\
\hline Religião & Católica & Católica & Não respondeu & Católica & Católica \\
\hline Escolaridade & $\begin{array}{c}\text { Até } 7^{\mathrm{a}} \text { série do } 1^{\circ} \\
\text { grau }\end{array}$ & Primário & Cursando ES & $\begin{array}{l}2^{\mathrm{a}} \text { Grau } \\
\text { Completo }\end{array}$ & $\begin{array}{l}2^{\mathrm{a}} \mathrm{Grau} \\
\text { Completo }\end{array}$ \\
\hline Ocupação & Aposentada & $\begin{array}{l}\text { Aposentada } \\
\text { Do Lar } \\
\end{array}$ & Todas & Artesã & Do Lar \\
\hline Naturalidade & Bahia/Juazeiro & $\begin{array}{c}\text { São Paulo/ } \\
\text { Paranapiacaba }\end{array}$ & São Paulo & São Paulo & São Paulo \\
\hline $\begin{array}{c}\text { Tempo de residência no } \\
\text { bairro }\end{array}$ & Há 22 anos & Há 41 anos & Há 17 anos & Há 28 anos & Há 27 anos \\
\hline $\begin{array}{c}\mathrm{N}^{0} \text { de pessoas que residem no } \\
\text { domicílio }\end{array}$ & 3 & 2 & 3 & 4 & 5 \\
\hline $\mathrm{N}^{0}$ de filhos/as & 1 & 3 & 2 & 2 & 3 \\
\hline Idade dos/as filhos/as & 38 anos & $22 ; 35$ e 41 & 29 e 33 & 21 e 27 & $8 ; 14$ e 18 \\
\hline Menores no domicílio & - & - & - & 1 & 2 \\
\hline $\begin{array}{c}\text { Grau de parentesco com } \\
\text { menor }\end{array}$ & - & - & - & neta & filhos/as \\
\hline Idade do/a menor & - & - & - & 6 meses & 8 e 14 \\
\hline $\begin{array}{l}\text { Horas de permanência em } \\
\text { creche e/ou educação infantil }\end{array}$ & - & - & - & 9 horas & 5 \\
\hline $\begin{array}{l}\text { Pessoas da moradia que } \\
\text { frequentam o CEU }\end{array}$ & Esposo & Esposo & Esposo e filha & $\begin{array}{l}\text { Esposo, filha e } \\
\text { neta }\end{array}$ & Filhos \\
\hline $\begin{array}{l}\text { Responsáveis por tarefas } \\
\text { domésticas em casa }\end{array}$ & Ela mesma & Ela mesma & Todos & Ela mesma & $\begin{array}{l}\text { Ela mesma e } \\
\text { filhos/as }\end{array}$ \\
\hline $\begin{array}{l}\text { Horas médias dedicadas aos } \\
\text { afazeres domésticos por dia }\end{array}$ & Dois dias/semana & Todo dia & 10 horas & 10 horas & 12 horas \\
\hline $\begin{array}{l}\text { Os homens realizam afazeres } \\
\text { domésticos em sua casa? }\end{array}$ & Às vezes & Não & Sim & Não & Sim \\
\hline $\begin{array}{l}\text { Trabalho fora de casa } \\
\text { quando conselheira }\end{array}$ & Não & Não & Sim & Não & Não \\
\hline $\begin{array}{c}\text { Situação profissional quando } \\
\text { conselheira }\end{array}$ & Aposentada & Aposentada & Dona do lar & Autônoma & Dona do lar \\
\hline $\begin{array}{l}\text { Ocupação ou função quando } \\
\text { conselheira }\end{array}$ & $\begin{array}{l}\text { Aposentada/ } \\
\text { Dona de casa }\end{array}$ & $\begin{array}{l}\text { Aposentada/ } \\
\text { Dona de casa }\end{array}$ & Dona de casa & $\begin{array}{c}\text { Dona de } \\
\text { casa/Autônoma }\end{array}$ & Dona de casa \\
\hline $\begin{array}{c}\text { Contribui para o orçamento } \\
\text { familiar }\end{array}$ & Sim & Sim & $\operatorname{Sim}$ & Não & Não \\
\hline Pessoa chefe da família & Esposo & Ela mesma & Deus & Esposo & Ela mesma \\
\hline $\begin{array}{l}\text { Benefícios de programas de } \\
\text { transferências de renda }\end{array}$ & Não & Não & Não & Não & Não \\
\hline Situação legal de moradia & Própria & Própria & Própria & Própria & Própria \\
\hline
\end{tabular}

\footnotetext{
${ }^{7}$ Os nomes utilizados na dissertação são fictícios a fim de preservar a identidade das mulheres conselheiras.
} 


\subsubsection{Mariana}

A primeira conselheira entrevistada foi a dona de casa Mariana, de 61 anos, branca, católica, solteira e com um filho de 38 anos. Natural de Juazeiro, na Bahia, veio para São Paulo em 1975 e somente em 1995 iniciou seus estudos, cursando até o $7^{\circ}$ ano, interrompidos por problemas de labirintite. A aposentada reside no bairro desde 1996, com seu companheiro e o filho. Ela me contou ter morado, anteriormente, na "cidade". Interessante notar que a região central de São Paulo foi identificada como "cidade" por Mariana, moradora de um bairro distante. Essa distância também não é somente física, mas, também, subjetiva, para quem mora nos bairros afastados, principalmente, para imigrantes, que podem considerar a "cidade" inacessível, não somente do ponto de vista físico, mas cultural, profissional e seu alto custo de vida. O que mostra a relevância dos equipamentos dos CEUs nos bairros. Antes de chegar ao Conselho Gestor do CEU, Mariana trabalhou por mais de vinte anos na metalurgia. Ela contribui para o orçamento do grupo familiar e afirma ter todos os serviços disponíveis em sua residência: telefone fixo, internet, rede pública de água, energia elétrica, esgoto, coleta de lixo, iluminação pública, pavimentação e guias e sarjetas.

O dia começa cedo para Mariana. Ela conta que costuma acordar por volta das 5 h30 para conciliar todas as tarefas. Assim que se levanta, realiza as atividades domésticas de lavar o quintal e cuidar de sua cachorra. Aproveita, também, para cuidar de sua saúde, tomando os remédios de combate ao colesterol e os da tireoide, para depois se dedicar ao preparo do café da manhã. Também, como parte dos cuidados à saúde, após o café, arrumase para ir às atividades físicas no CEU. Às segundas, quartas e sexta-feira faz caminhada, e às terças e quintas-feiras realiza ginástica. Quando tem outra atribuição fora do circuito casa-CEU, encaminha-se para o compromisso logo após o término das aulas de ginástica. A estratégia de Mariana, para conciliar as atividades fora de casa é adiantar as tarefas do lar, acorda cedo, assim, quando retorna para a casa, as tarefas estão todas prontas. Dessa forma, ela diz dar conta de todos os compromissos.

O filho e o marido de Mariana trabalham fora de casa, cabendo a ela a responsabilidade pelos afazeres domésticos; ela costuma dedicar dois dias da semana para essas tarefas. Somente quando Mariana está ausente que o filho prepara os alimentos. Mas ela lembra que costuma preparar com antecedência a comida para facilitar a organização do filho que, assim como o marido, também costuma lavar a louça na ausência da 
conselheira. Entretanto, conta que a participação deles na divisão dos afazeres domésticos é eventual.

Mariana não utiliza o transporte público para se locomover ao CEU, já que reside na proximidade. Também gosta de "bater perna". Contou-me que o tempo de deslocamento de sua casa até o Centro Educacional é de, no máximo, 10 minutos. Semanalmente se dirige aos outros bairros de trem ou ônibus. O tempo de deslocamento da estação de trem do Jaraguá até a estação de trem da Lapa, onde costuma ir, dura, aproximadamente, 25 minutos. Já o percurso entre as duas localidades, realizado por ônibus, é de 1 hora, aproximadamente. Ela diz preferir se locomover de trem pela sua rapidez, e utilizar ônibus quando tem algum compromisso fora do bairro, como as sessões de fisioterapia, de acupuntura e todas as outras tarefas que não realiza no próprio bairro.

Eventualmente, quando não viaja, nas horas de lazer, gosta de frequentar o Sesc Pompeia e o Sesc Belenzinho, para observar as pessoas. Mariana contou-me que gosta de ir ao Parque Anhanguera e Perus para relaxar, fazer churrasco e tomar cerveja, e que não gosta de sair sozinha. Contou, ainda, que sai pouco de casa nos finais de semana, porque seu marido trabalha como segurança.

Como passatempo, Mariana gosta de assistir à programação religiosa católica do terço e as programações televisivas das missas, antes de dormir, após também assistir à novela. Mesmo assim, ela me contou não gostar e não ter paciência de assistir à televisão.

Já, nas horas vagas, Mariana gosta de fazer crochê e depois vende os produtos finalizados quando há alguma festividade no CEU. Embora exponha seus produtos nos eventos do CEU, sabe da dificuldade de venda. Ela contou que os usuários que frequentam o CEU durante os eventos não estão interessados em comprar artesanato devido ao alto preço; eles preferem comprar alimentos. Os produtos que Mariana produz são tapetes, toalhas bordadas em fita, porta-joias, jarras e chinelos bordados em pedraria.

No mesmo dia em que conheci Mariana no CEU, antes da nossa entrevista, ela me entregou um cartãozinho com seu contato telefônico, o mesmo que utiliza para divulgar a venda de bolos para clientes. Durante a entrevista, perguntei se em sua rotina diária sobrava tempo para preparar e vender bolos. Ela me afirmou que, para não ficar presa a esse compromisso, não produzia e nem comercializava mais bolos. Ficou com meu contato de celular e, em alguns momentos dos meses de maio, junho e dezembro de 2018 , me enviou por meio do WhatsApp mensagens de boa noite, fotos de divulgação do seus bolos caseiros com a cobertura de massa de biscuit e pasta americana, além de me perguntar se eu havia 
lhe procurado interessada em alugar casa na praia. Não foi por acaso que durante a entrevista me contou que tem muitas amizades.

\subsubsection{Lilian}

Lilian, branca, 61 anos, aposentada, católica, nasceu em Paranapiacaba e reside na cidade de São Paulo no mesmo bairro desde 1977. Divorciada, convive desde 2012 com o atual marido e alguns bichinhos de estimação, que herdou de sua mãe quando ela faleceu. Lilian foi a segunda conselheira entrevistada e é a responsável pelo trabalho doméstico dedicando-se todo dia aos afazeres.

Tem três filhos, com 41, 35 e 22 anos. Uma das filhas reside em um bairro mais distante, a outra filha na cidade de São Carlos e o mais jovem nas proximidades do bairro onde ela mora. Desde 2016, esse filho e a nora se mudaram da casa de Lilian para um apartamento próximo à mãe.

Contou-me já ter residido por um ano no município de Mauá e em Pirituba até ter chegado ao bairro onde mora, em São Paulo. Quando chegou, já tinha o diagnóstico de esclerose múltipla, doença neurológica crônica que compromete o sistema nervoso central. Disse-me ter perdido toda força muscular, sensibilidade, tato, coordenação dos movimentos e outros, entretanto, desde que se ocupou das atividades no CEU, percebeu uma melhora em sua saúde, porque atualmente consegue se locomover para qualquer lugar, assim como fazer muitas atividades dentro de suas limitações. Ela atribui essa melhora ao fator psicológico, porque ficou responsável por criar seu filho pequeno e com problema de saúde; relata ter despertado e se considera atualmente uma pessoa ativa.

Lilian estudou quase todo o ensino fundamental 1 e destaca que, nos quatro anos que cursou, pôde aprender mais do que o ensino médio atual. Embora tenha estudado o "primário", atribui ao trabalho o conhecimento que possui.

É aposentada e desde que começou a atuar no Conselho Gestor do CEU tem essa ocupação. Disse-me que anteriormente trabalhava na área de comunicação da Siemens, conglomerado industrial alemão, onde foi datilógrafa, telefonista e responsável por cuidar de toda parte de comunicação da empresa e que para lá se deslocava diariamente a pé. Lilian não se considera uma pessoa acomodada, porque sempre trabalhou fora de casa e buscou qualificação profissional, em atividades que foram extintas na atualidade, como cursos de datilografia, de xerox, de telexista e de radiotelegrafista. Ela era responsável pela operação 
e manutenção dos sistemas de telecomunicações em navios. Contou ter criado toda sua família com o sustento do trabalho na Siemens.

Assim como as outras entrevistadas, Lilian nunca recebeu benefícios de programas de transferência de renda. Considera-se a chefe da família, pois sempre foi a responsável pelo pagamento das contas, além de ter sido a responsável pela compra do terreno, nos finais dos anos de 1980, e pela construção da casa que atualmente reside. Ainda lembra o cenário do bairro na época que comprou o terreno, já que a região somente havia pasto. Anos depois, com a inauguração do CEU, em 2003, o bairro foi sendo povoado e, com a inauguração da estação de trem, em 2013, houve uma significativa melhora para a população local. Assim como as outras mulheres entrevistadas, a região em que mora é atendida por telefone fixo, internet, rede pública de água, energia elétrica e rede de esgoto. Também é servida pela coleta de lixo, iluminação pública, guias e sarjetas e de pavimentação.

Lilian utiliza os meios de transporte público de trem, ônibus e van de lotação, para se deslocar dentro do bairro quase que diariamente. Semanalmente vai ao médico ou à massagista. Gosta de caminhar a pé, mas desde que foi surpreendida por um rapaz, enquanto andava pelo bairro, diz ter ficado com medo de andar sozinha. Em sua abordagem, o homem quis saber se a conselheira possuía celular, internet e se ela gostaria de ir para a casa dele.

Mesmo não dependendo de transporte público para ir ao CEU, já que reside próximo e vai a pé ao Centro Educacional, Lilian tem se preocupado com o corte de linhas de ônibus, em operação pela prefeitura, pois depende desse transporte para se locomover para outros lugares. Recentemente a linha onde sua filha mora foi tirada de circulação.

Com a unificação das linhas feita pela Prefeitura, desde janeiro de 2018, Lilian teme que o corte de linhas de ônibus municipais afete mais sua vida. Ela utiliza as linhas que a levam até onde sua mãe morava. Mesmo com o falecimento de sua mãe, ela costuma visitar amigas na localidade. E, também, as linhas que permitem o trânsito para a realização de exames de saúde. Com a mudança, Lilian é obrigada a fazer uma parte do percurso a pé e "pegar" ônibus que já vem lotado.

A relação de Lilian com o Conselho Gestor do CEU começou desde seu início, assumindo a presidência em uma de suas gestões. Não deixa de frequentar o CEU para realizar as atividades físicas e culturais oferecidas, além de participar das reuniões do Conselho Gestor, mensalmente, desde a existência do Centro Educacional. Seu esposo também frequenta o centro para a prática de atividades de ginástica. 


\subsubsection{Nair}

A terceira entrevistada foi a conselheira Nair ${ }^{8}$, de 55 anos. A conversa com ela foi extremamente útil para perceber o que não é dito no espaço do Conselho, mas que é relevante na compreensão da atuação das mulheres no CEU. Casada, seu marido é assalariado, trabalha em uma faculdade privada, tem dois filhos, de 33 e 29 anos de idade, e se autodeclarou possuir "todas" as raças/etnias. Nascida em São Paulo, questiona o trabalho doméstico e enfatiza o seu desejo de viver em casa e não de viver para a casa, assim como atribuiu à figura do marido a dificuldade das mulheres em participarem das atividades do CEU.

Na ocasião da entrevista, Nair já não fazia mais parte do Conselho Gestor do CEU, mas me relata sua rotina, considerando o período em que esteve no colegiado. À medida que Nair ia me contando sua rotina - acordar cedo, tomar café, preparar o almoço e limpar a casa - afirmava que sua casa não é suja, e emendava uma observação sobre a quantidade de bibelôs e ímãs de geladeira na casa de sua cunhada. A conselheira me contou que procura ter objetos em casa de modo que a limpeza desses não a limite. Nair também procura adiantar algumas tarefas para não atrapalhar sua rotina fora de casa. Chegou a brigar muito com o marido, quando teve algum compromisso, para que ela pudesse deixar de fazer determinadas tarefas domésticas. Ela me disse que o marido administra as tarefas em sua ausência. O interessante da estratégica adotada por Nair é que ela não pretende se enquadrar em nenhuma rotina ou modelo tradicional, mas diz tentar uma forma diferente de sua mãe e avó, como ela mesmo me disse. Coloca em questão esse modelo vigente da mulher estar em casa à disposição dos afazeres domésticos em um momento que a tecnologia colabora na racionalização do tempo de trabalho doméstico, com o uso da máquina de lavar roupa, por exemplo. Diz que todos em sua casa são responsáveis pelas tarefas domésticas, mas ela dedica de 8 a 10 horas, diariamente, para o desempenho dessas atividades.

Ela sempre teve um trabalho com jornada flexível, com folgas no meio da semana, por essa razão, nunca estabeleceu dias da semana para determinado tipo de afazer doméstico. Sendo assim, cada membro da família foi entendendo sua responsabilidade em casa. Nair me disse que sua filha pediu que não a obrigasse a servir o pai e nem o marido.

\footnotetext{
${ }^{8} \mathrm{Na}$ ocasião da entrevista, Nair já havia saído do Conselho Gestor do CEU.
} 
Antes de chegar ao Conselho Gestor, trabalhou tanto no setor administrativo, como datilógrafa e, posteriormente, em contato com o público, no antigo hospital Sorocabano, na Lapa, na época de solteira. Após essa experiência no hospital, desempenhou atividade profissional em um orfanato, por seis anos, no início do ano 2000. Desenvolveu trabalhos administrativos em vários locais particulares, sendo responsável pela documentação e pagamento de contas etc. Decidiu abandonar o trabalho administrativo por problemas respiratórios e entrou para o Conselho Gestor para se informar e participar ativamente da comunidade no CEU duas vezes na semana.

Nair começou a frequentar o CEU em 2010 e conheceu o Conselho Gestor a convite dos funcionários. Participou de diversos coletivos no Centro Educacional Unificado como o grupo cultural, o grupo de Mulheres ligado ao CEU pesquisado, a Comissão da Verdade; o Conselho Gestor, além de grupos de atividades físicas, único grupo de atualmente frequenta.

Atualmente cursa o primeiro semestre do ensino superior em uma universidade privada no período da noite, mas como vive o dilema da dificuldade da conciliação do tempo de estudo com o tempo dedicado aos afazeres domésticos, cogita a mudança de turno na faculdade para que possa se dedicar de manhã aos estudos. Dessa forma, acredita que poderia estudar em casa de noite, sem a preocupação com o trabalho doméstico. Embora o público de estudantes que frequenta as aulas no período noturno seja adulto, assim como ela, Nair diz não ter problema de se relacionar com o pessoal mais jovem.

Contou-me sobre sua dificuldade de aprender química na faculdade, porque nunca aprendeu essa disciplina na escola. Quem lhe lecionou química, naquela época, foi seu professor de educação física. Nair, em sua fala, valoriza a responsabilidade e o trabalho, fundamentais pilares educativos na época escolar, quando estudava no bairro da Freguesia do Ó. Ela lembra da sua educação como uma época em que brincava na rua e valorizava a convivência e o respeito com as pessoas de mais idade.

Ensinou seus filhos uma educação não consumista. Dessa forma, me falou que nunca trabalhou para comprar brinquedos aos filhos, mas possibilitou que eles brincassem na rua. Contou ser originária de uma geração que possuía muitas dificuldades com cuidados dentários, e por isso nunca quis que seus filhos tivessem dor de dente. Nesse seu relato, elogiou a atual geração de jovens que possui uma bela dentição, devido, principalmente, à política de saúde pública de flúor. Disse-me que o que lhe permitiu ainda manter um pouco mais de dentes foi ter "gastado" com tratamento dentário. 
Nair diz que todos os serviços básicos atendem à sua residência, de situação legal própria: telefonia fixa, internet, coleta de lixo, pavimentação, rede pública de água, de energia elétrica, esgoto e iluminação pública e guias e sarjetas. Antes de se mudar para o bairro onde reside, Nair morou no bairro da Freguesia do Ó, desde o início dos anos 2000. $\mathrm{Na}$ ocasião da entrevista, ela costumava comprar tudo no bairro para promover a circulação monetária, o desenvolvimento, a geração de emprego e a renda local. Também ela prefere comprar produtos orgânicos da própria região, como hortaliças, café e banana. Contou, também, que contribui com aproximadamente $20 \%$ para o orçamento de seu grupo familiar, e considera Deus ser o chefe de sua família, principalmente, por seu princípio de amor.

Sobre seu momento de lazer, Nair me revela sua preferência por frequentar espaços no entorno, por pertencer à localidade, com o intuito de saber como as pessoas estão vivendo e como se organizam. Os dois filhos de Nair são formadores em artes, assim, no período em que ela participava do Conselho Gestor, acompanhava as apresentações deles, desde no Teatro Municipal até no próprio CEU. Ela destaca que priorizava acompanhar os shows fora do bairro, como forma também de andar e conhecer mais a cidade.

Nas horas de lazer, Nair gosta de sair de casa, estar entre pessoas, de conversar, principalmente quando encontra amigas de longa data. Ao longo da entrevista, mencionou mais de uma vez gostar de conhecer pessoas, de abraçar, de beijar e valorizar o toque. Ela vê as pessoas do bairro como uma extensão de sua família. Também assiste na TV Cultura ao programa Panorama. Gosta de passar informações para amigas através desse programa, depois do meio-dia, com temas da atualidade.

Como ela afirma não ser consumista, nem o marido, ambos têm se planejado para viajar e conhecer o Brasil, e o trajeto da viagem feita em 2016 e 2017 foi de retornar ao nordeste, para conhecer melhor os antepassados; ela e o esposo foram para a Bahia, e, mais recentemente para Paripueira, Alagoas.

Quando frequentava o CEU, disse que gostava de se aproximar das gerações mais novas. Enquanto conversava comigo sobre o diálogo que ela tinha com os jovens que gostavam de frequentar o Parque Vila Lobos em detrimento do Parque Anhanguera, lembrou que havia feito pesquisa e detectado que a região possui um centro de tratamento de animais. Como não se lembrava do nome do local, me disse que deveria ter trazido seu caderno de anotações que ela possui. Mas como achou que a nossa conversa fosse ter outra abordagem, não trouxe, até para que a entrevista não se limitasse às suas anotações.

Como tem problemas de saúde respiratórios, Nair não deixa de reparar na questão da higiene nos lugares que circula. E por isso me contou da falta de higiene nos transportes 
públicos, principalmente, nos trens. Disse que quando circula de transporte público prefere agendar seus compromissos em horários de baixo pico, já que tem essa flexibilidade de horário.

Boa parte da entrevista com a Nair foi caracterizada por sua fala sugestiva de políticas a serem adotadas junto à população em que ela vive. Quando conversava com ela sobre o tema dos transportes, ela contou do seu problema de saúde e me sugeriu algumas ideias de políticas, como, por exemplo, adotar nas televisões dos trens e metrôs programas educativos de higiene, intercalados com programação sobre o determinado bairro que o trem percorre na linha, os muros da estação de trem deveriam contar a história do bairro, e até mesmo a transmissão de música clássica para a população que, muitas vezes, não tem tempo de se informar, na rotina de trabalho, transporte e casa. Emenda afirmando que as políticas públicas devam chegar à população, e não a população ter de reivindicar. Alegou estar cansada, assim como muitas pessoas de sair às ruas e reivindicar melhorias sociais aos políticos.

\subsubsection{Mercedes}

A quarta mulher entrevistada foi Mercedes, de 53 anos, negra, casada e mãe de dois filhos (a moça de 21 e o rapaz de 27 anos). Ela também me disse ser católica. Moradora bem antiga no bairro, desde o início da década de 1990, atualmente é artesã e estudou o ensino médio completo.

Mercedes reside em casa própria, em frente ao CEU, e considera o Centro Educacional como continuidade do seu quintal de casa. Seu domicílio é atendido pelos serviços de telefonia fixa, internet, rede pública de água, energia elétrica, esgoto, coleta de lixo e iluminação pública, assim como pavimentação de ruas e guias e sarjetas.

Ela mora com o esposo, sua filha e a netinha de seis meses de vida. Sua filha é a responsável pelo cuidado da menor de idade, que frequenta o Centro de Educação Infantil (CEI) do CEU, no período das 8 h às $17 \mathrm{~h}$. Há um mês, na ocasião da entrevista, seu genro se mudara para Santa Catarina para buscar recolocação profissional após perder o emprego em São Paulo. Mercedes diz ter oferecido a residência para o casal morar, oferta recusada pelo companheiro da filha. Já o filho mais velho de Mercedes reside com a avó, de 88 anos, e somente aparece aos finais de semana.

A conselheira me relatou que antes da construção do CEU, o local era um terreno baldio, que ela participou da limpeza, além de ter presenciado todas as vezes que a exprefeita Marta Suplicy esteve no local. Lembrou-se da colocação da placa no dia da 
inauguração do CEU, evento que contou com a presença de muitos moradores. Ela recorda ainda a fala da ex-prefeita Marta Suplicy à comunidade: "Gente, aqui é de vocês, é pra vocês, é para as famílias, é para os filhos, é para os moradores, só que a partir de hoje, nós fizemos, nós construímos, só que vocês que vão ter que cuidar disso daqui”".

Foi a partir do início dos anos 2000, aproximadamente, que Mercedes começou a trabalhar somente em casa, sem registro em carteira. Logo em seguida da inauguração do Centro Educacional Unificado, em 2003, ela começou a participar das atividades esportivas oferecidas pelo novo equipamento, como mera usuária. Mesmo morando em frente ao novo equipamento educacional, não conseguiu vagas para os filhos no $\mathrm{CEU}$, eles tiveram de ser matriculados em uma escola vizinha.

Como seu esposo sempre trabalhou fora de casa, Mercedes com os filhos pequenos em idade escolar buscava conciliar os horários de participação das atividades esportivas do CEU com a jornada de trabalho doméstico no cuidado do lar, marido e filhos. Atualmente o marido é o responsável pelo orçamento do grupo familiar.

Mercedes tornou-se conselheira pelo convite do professor de ginástica. Está no conselho desde 2011, e nunca participou de nenhum outro movimento social organizado. Contudo, disse-me ter gostado de política durante toda sua juventude, devido à profissão de metalúrgico de seu pai, que levava Mercedes e seus irmãos para os espaços de organização sindical dos trabalhadores. Contou-me que no passado era considerada "petista roxa" devido à sua combatividade e por ser muito ativa. Entretanto, não acredita que o Partido dos Trabalhadores (PT) esteja voltado para os interesses das causas dos trabalhadores atualmente, motivo pelo qual disse anular o voto nas eleições, exceto se Marta Suplicy se candidatar. A conselheira declara voto na ex-prefeita Marta Suplicy, independentemente de seu partido.

Para que possa dar conta de todas as atividades, Mercedes me conta que aprendeu a se organizar, e só se ausenta das aulas no CEU quando adoece. Antes de assumir o Conselho Gestor, em 2010, sofreu um aneurisma cerebral, que a fez passar um mês internada na UTI do hospital Metropolitano, na Lapa, e realizou uma cirurgia na cabeça com 28 pontos. Ela me relata que pesava 15 a 20 quilos a mais que atualmente. Mesmo assim, Mercedes não larga o vício do cigarro. A conselheira diz que manter as atividades no CEU faz com que sua ansiedade esteja sob controle, impedindo-a de fumar, principalmente, quando está sozinha em casa.

As atividades físicas realizadas no CEU trazem benefícios para sua saúde. Atualmente frequenta as aulas de caminhada, mesmo sem estar matriculada, três vezes na 
semana, às segundas, quartas e sextas-feiras, há dois anos. Às terças e quintas-feiras, das $18 \mathrm{~h}$ às $19 \mathrm{~h}$ realizava alongamento, antes das aulas se encerrarem, no mês anterior à entrevista. Em substituição ao horário, faz aulas de tae kwon do e, aos sábados, Mercedes frequenta as aulas de zumba. Seu marido também frequenta as atividades esportivas do CEU. Ele faz aulas de ginástica e participa do grupo de corrida e caminhada. O grupo, criado pelo professor do CEU, reúne-se para participar das corridas em outras localidades, possibilitando com que Mercedes viaje acompanhando seu esposo nas corridas fora do $\mathrm{CEU}$, conciliando as atividades do grupo do CEU, a companhia do marido e os momentos de lazer.

Há pouco mais de um ano, Mercedes e o marido compraram um apartamento na praia, para onde a família viaja nos feriados, muitas vezes em companhia da filha e da neta. A dona de casa ainda reserva espaço na sua rotina diária de atividades, fazendo trabalho de artesanato em sua própria residência. Para ajudar sua filha, Mercedes realiza trabalho autônomo de produção de pulseiras. A conselheira destaca que, embora seja artesanato, o produto que sua filha desenvolve é realizado em uma fábrica com maquinário. Já, o seu filho, que aprendeu natação nas piscinas do CEU, é músico e toca cavaquinho como freelancer e outros instrumentos de corda; ele participa de um grupo de pagode. Como ele toca em outras localidades, Mercedes o acompanha sempre que pode, sendo uma oportunidade para passear.

Ela conta que, antes de sofrer o aneurisma cerebral, era exigente e brigava para manter a limpeza, a organização e as tarefas de casa. Atualmente, não é exigente com a limpeza e, também, não se dedica aos afazeres, em período integral, como antigamente, mas procura cobrar dos outros moradores a limpeza, organização e manutenção da casa.

Foi eleita para o Conselho Gestor do CEU automaticamente já que não havia mais representantes para sua categoria. Participa do colegiado como representante familiar de aluno na comunidade, visto que sua neta estuda no equipamento educacional.

\subsubsection{Renata}

Renata, 37 anos, três filhos, casada, seu marido trabalha fora de casa, estudou o ensino médio completo e se mostrou bastante desenvolta em responder às perguntas. Ela trabalha no cuidado do lar, dos filhos e do marido. Foi a quinta conselheira entrevistada e a mais jovem. Também foi a única que respondeu em tom de dúvida quando interrogada sobre sua raça/etnia. Ela é parda, mas se questiona: “Ai meu Deus, que cor eu sou, gente? Branca?" 
Casada há quase 20 anos, tem três filhos do sexo masculino, com idades de 18, 14 a 8 anos. É a única das mulheres entrevistadas com fillhos menores. Casou-se jovem, com dezessete para dezoito anos de idade. Todos os filhos estudam, e o mais novo está matriculado no CEU.

A conselheira é católica, natural de São Paulo e residente no bairro desde o início da década de 1990. Mora com seu marido e seus três filhos nas proximidades do CEU, em moradia própria. Assim como as outras entrevistadas, não recebia nenhum benefício de programas de transferência de renda. Também afirmou que sua moradia é atendida pelos serviços de telefonia fixa, internet, rede pública de água, de energia elétrica e de esgoto, além da coleta de lixo, iluminação pública, mesmo que tenha destacada que esse serviço é precário. Também tem o atendimento do serviço de guias e sarjetas e de pavimentação.

O seu dia a dia é vivenciado em casa na presença dos filhos. O mais velho trabalha e estuda durante a semana, mas não deixa de participar da divisão dos afazeres domésticos. Aos finais de semana, ele fica responsável pela faxina no quarto e as louças do almoço e do jantar. Os dois mais jovens, embora estudem, também colaboram com as atividades do lar. Renata faz questão de envolvê-los nas tarefas domésticas e compara o lar a uma empresa, que para ser bem administrada necessita de uma chefia. Ela é quem é a responsável pelos afazeres e por organizar a participação de cada filho nas tarefas domésticas. Embora o marido seja o arrimo financeiro da família, Renata se considera a chefe de sua família, e ele permite que ela também participe da chefia e dos poderes em casa.

Renata dedica-se no cuidado da casa e de sua família. Contou-me que praticamente toda sua vida se concentra no bairro, sendo difícil se deslocar para outra localidade. Às vezes, sai do bairro e se dirige ao bairro adjacente, em Pirituba, para visitar alguns parentes. Para se deslocar, utiliza o transporte público do ônibus ou vai de carro. Aproveita para criticar a limitada quantidade de ônibus disponível no bairro, o grande intervalo de espera nos pontos e os ônibus velhos que circulam no bairro. Denuncia que enquanto os bairros centrais têm ônibus novos, para o seu bairro são destinados ônibus velhos.

Quando utiliza o carro para sair do bairro, reclama das crateras e da qualidade das pavimentações das vias por onde circula e da falta de manutenção das ruas que, por suas irregularidades no asfalto, leva à deterioração e à constante manutenção do seu automóvel. E quando sai de carro, costuma também sair com os filhos, para ir ao cinema, ao parque ou na casa da avó. Semanalmente, também leva os filhos para jogar futebol. O espaço do CEU também é utilizado para trazer os filhos para jogar futebol. 
Considera ter uma vida "normal" como dona de casa. Contou-me do seu gosto de conversar e de abraçar as pessoas e me relatou, com toda a ênfase, que cultiva muitas amizades.

Renata frequenta o CEU desde 2015. Atualmente, além de tratar de assuntos educacionais de um dos filhos, também frequenta mais vezes na semana atividades de ginástica funcional e caminhada, além dos outros serviços oferecidos à comunidade. Ela me contou que antes utilizava o espaço educacional como uma usuária do serviço, mas devido à sua inserção no Conselho Gestor, a relação com o CEU também mudou.

Atualmente é dona do lar, mas me contou já ter trabalhado fora de casa, porém não no período de atuação no Conselho Gestor. No momento da entrevista, contou que era seu segundo ano como conselheira no CEU, tendo iniciado sua participação no colegiado em 2017, a convite de Mercedes.

A dona de casa Renata representa a comunidade no Conselho Gestor, desde que foi convidada pela outra conselheira, Mercedes, a ir às reuniões. Disse-me ter conhecido e tomado gosto pelos encontros mensais do colegiado e por isso está presente em todas as reuniões. Após ter se aproximado do Conselho Gestor, passou a se envolver mais com as atividades do $\mathrm{CEU}$, como a presença na participação de festas na escola e das outras atividades oferecidas, para além do espaço educacional. Disse-me que, tendo alguma ideia ou dúvida sobre algum encaminhamento sobre o CEU, desce a rua da casa até o Centro Educacional para conversar com a gestora. A proximidade de sua casa com o CEU facilita essa sua ação. 


\section{AS MULHERES NO CONSELHO GESTOR DO CEU: MOTIVAÇÕES, EXPERIÊNCIAS E APRENDIZADOS}

É crucial que aqueles de nós que resistem e se rebelam, que sobrevivem e têm sucesso, falem aberta e honestamente sobre nossas vidas e a natureza de nossas lutas pessoais, os meios pelos quais resolvemos e reconciliamos contradições. Não é uma tarefa fácil. Nas instituições educacionais onde aprendemos a desenvolver e fortalecer nossas habilidades de escrita e análise, também aprendemos a pensar, escrever e falar de uma maneira que tira a atenção da experiência pessoal. Porém, se quisermos alcançar nosso povo e todas as pessoas, se quisermos permanecer conectados (especialmente aqueles de nós cujas origens familiares são pobres e de classe trabalhadora), devemos compreender que o relato da história pessoal de alguém fornece um exemplo significativo, uma forma de as pessoas se identificarem e se conectarem. bell hooks (2019)

Neste capítulo, apresento em formato de narrativas os relatos sobre o envolvimento das cinco mulheres entrevistadas junto ao Conselho Gestor. Em alguns momentos, também recorro a algumas contribuições da entrevista junto à atual gestora do CEU, apenas quando essa colabora para esclarecer assuntos ligados à gestão.

Os tópicos aqui agrupados procuram mostrar os caminhos que foram percorridos para a inserção dessas mulheres em um espaço público, entendendo o conceito de espaço público como ambiente fora da casa e de qualquer outro espaço privado. Foi importante, também, apreender que falar sobre as suas histórias no Conselho Gestor é, também, relatar uma história pessoal que reflete uma idade, uma trajetória e um momento da vida, uma forma delas se identificarem e se conectarem. Após muitas leituras e reescritas, pude perceber que ao contarem sobre como chegaram ao Conselho Gestor, sobre suas motivações e os significados de participação diziam muito de como resistem e se rebelam, como sobrevivem e têm sucesso. As falas abertas, diretas ou algumas vezes sutis, tímidas e até concisas mostram a natureza dessas lutas pessoais diante das dificuldades e, também, suas contribuições da participação no Conselho Gestor em suas vidas.

\subsection{DA CASA PARA A RUA}

Para entender a participação das mulheres conselheiras no espaço do Conselho Gestor, foi preciso ter em mente suas experiências de saída do espaço doméstico anteriores à participação no conselho. Participação essa que pode ser aquela vivenciada na infância nas brincadeiras de ruas, no trabalho, na escola, em algum episódio de atuação em movimento de bairro ou até a inserção em coletivos dentro do local de trabalho. Foi 
importante compreender a inserção participativa no espaço público, para além do entendimento de participação do senso comum, no campo político. $\mathrm{O}$ antropólogo Roberto DaMatta (1997), ao tratar das categorias sociológicas da casa e rua, aborda o caráter dicotômico de ambas entidades. Seu interesse em estudar os fatos sociais se justifica pela possibilidade de "ler a sociedade brasileira" (DAMATTA, 1997) por meio dos rituais. Enquanto os rituais públicos, de controle do Estado e/ou da Igreja partem da rua, os eventos privados, partem do âmbito doméstico. $\mathrm{O}$ conceito depreendido pelo autor é útil para o entendimento do movimento da saída das conselheiras da casa para a rua. Assim ele expõe:

Em todo caso, se a casa distingue esse espaço de calma, repouso, recuperação e hospitalidade, enfim, de tudo aquilo que define a nossa ideia de "amor", "carinho" e "calor humano", a rua é um espaço definido precisamente ao inverso. Terra que pertence ao "governo" ou ao "povo" e que está sempre repleta de fluidez e movimento. A rua é um local perigoso. (DAMATTA, 1997, p. 44)

Mas a casa, para muitas mulheres, pode ser também espaço de confinamento e de intenso trabalho. Assim, a questão fundamental desta dissertação é analisar como essas mulheres saem da casa para a rua e, nesse trajeto, como a participação no Conselho Gestor do CEU influencia suas vidas que, apesar de compartilharem de uma origem socioeconômica semelhante, têm suas trajetórias anteriores à participação no CEU distintas, e, portanto, possuem caminhos diversos de inserção no espaço público.

A primeira entrevistada foi a aposentada Mariana ${ }^{9}(61)$, dona de casa, solteira e mãe de um filho de 38 anos. A baiana de Juazeiro do Norte, tem integrantes da família com envolvimento na política, mudou-se para São Paulo com 17 anos, aproximadamente, e depois trabalhou em uma metalúrgica durante vinte anos, antes de chegar ao Conselho Gestor do CEU. Somente após se aposentar, em 2009, é que encontrou tempo para se dedicar ao Conselho, e ela se identificou com o novo espaço. Podemos perceber que o CEU substitui o espaço de sociabilidade que o trabalho fora de casa outrora cumpria:

Antes de entrar no Conselho Gestor, eu trabalhava em empresa, eu trabalhava fora, aí quando eu me aposentei, eu resolvi vir para o CEU. Para não ficar em casa parada. Então aqui no CEU, pelo que eu passei aqui, acho que era muito a casa minha.

Heleieth Saffioti e Vera Ferrante (1986/87), ao analisarem a participação das mulheres nos sindicatos rurais de Araraquara, observaram um caminho semelhante ao de Mariana ao revelarem que a participação das mulheres pode indicar "uma revitalização da

\footnotetext{
${ }^{9}$ Os nomes e eventuais identificadores das entrevistas foram alterados
} 
tentativa das mulheres de romper sua circunscrição ao espaço do cotidiano e imprimir às suas lutas uma dimensão mais pública.” (1986/87 p. 103)

O início da participação no CEU por Mariana ocorreu de forma espontânea. Ela tinha muita vontade de frequentar o CEU, todavia não havia conciliação do expediente de trabalho com o horário das reuniões do Conselho Gestor. A primeira chamada para o início das reuniões ocorria às $13 \mathrm{~h} 30$ e às $17 \mathrm{~h} 30$, e isso a impedia de estar no CEU trabalhando fora de casa.

Porque eu tinha vontade de vir, mas o horário nunca batia porque eu entrava no serviço seis horas da manhã e saía 17 h30, então até chegar aqui você não consegue fazer mais nada.

Portanto, o percurso das mulheres da casa até a rua, ou seja, até ao CEU, é feito, principalmente, quando do espaço doméstico, o da invisibilidade, elas se voltam ao espaço público, onde cada uma delas traça seu caminho de participação. Segundo Saffioti e Ferrante, (1986/87) durante a "trajetória de casa para a "rua", ainda que se debatendo em suas contradições, as mulheres buscam não apenas ocupar as brechas eventualmente deixadas abertas, mas também forçam a criação de novos espaços para sua participação política”. (SAFFIOTI, FERRANTE, 1986/87, p. 109).

\subsubsection{Porque realmente o trabalho doméstico da mulher nunca foi visto como um trabalho}

Entre as mulheres entrevistadas, todas relataram que o trabalho doméstico e o cuidado com filhos e marido fazem parte da rotina de vida no espaço privado do lar, independente da condição de ocupação ou da idade. A definição de trabalho doméstico utilizada por Helena Hirata designa "um conjunto de tarefas relacionadas ao cuidado de pessoas e que são executadas no contexto da família - domicílio conjugal e parentela envolve o trabalho gratuito realizado essencialmente por mulheres”. (HIRATA, 2009, p. 257) O termo trabalho doméstico compreende uma gama de entendimentos, até controversos, que significa produção doméstica, economia doméstica, serviço doméstico, atividade do lar, atividades domésticas, cuidadora de pessoas, dona de casa, esposa, mãe, segundo Hirata. (2009, p. 256-257)

Embora Mariana, de 61 anos, divida o mesmo teto com o marido e o filho, que na ocasião da entrevista iria completar 38 anos, a divisão dos afazeres domésticos não era feita de forma equitativa entre os membros da casa. Somente quando da ausência de Mariana, seu filho é responsável por preparar a comida e lavar a louça. Mesmo assim, Mariana 
lembra deixar pronta as tarefas, facilitando o trabalho do filho que, assim como o marido, também lava a louça quando ela não está presente. Observo que os homens da casa realizam algumas tarefas domésticas somente quando a principal responsável pelas tarefas domésticas se ausenta:

O meu filho se ele chegar em casa e eu não tiver em casa e ele tiver com muita fome, ele vai para o fogão e ele faz. Mas geralmente eu deixo pronto.

Quando indagada sobre sua organização ao participar do Conselho Gestor, considerando a rotina de atividades físicas realizadas no próprio equipamento educacional com a conciliação das responsabilidades domésticos e familiar, a conselheira destaca:

Eu organizo tudo porque em casa não me impede de eu ir em lugar nenhum. Porque se eu chegasse em casa e fosse impedida de ir em algum lugar eu não faria nada. Mas eu não tenho esse tipo de coisa em casa. (Mariana)

A rotina e a organização familiar, tanto do filho e do marido, que trabalham fora de casa, dependem da organização do tempo e do trabalho desempenhado por Mariana, logo nas primeiras horas do dia, já que ela diz acordar cedo para conseguir dar conta das tarefas. A conselheira não somente é responsável pela sua organização do tempo e das suas atividades no CEU, por exemplo, como também é responsável pela racionalização da estratégia do tempo das atividades domésticas do filho, com o objetivo de facilitar o trabalho ao "deixar tudo pronto" para ele. Ou seja, o trabalho doméstico de Mariana também é organizado para "facilitar" o trabalho doméstico executado pelo filho. $\mathrm{Na}$ verdade, esse "facilitar" o trabalho para o filho seria nada menos do que a terceirização do trabalho para a execução da conselheira. O trecho a seguir destaca a racionalização empregada na rotina de Mariana com o objetivo de "adiantar" suas tarefas:

Eu procuro sempre deixar as coisas prontas em casa porque se eu levanto cedo, dá tempo de fazer minhas coisas, aí eu já faço. Se eu for sair, eu vou chegar um pouco mais tarde, então eu já deixo pronto. Não tem assim, coisas assim para eu sair de casa e eu "eu não vou fazer isso hoje porque não vai dar tempo". Meu tempo dá para tudo.

Para poder acordar cedo, a conselheira geralmente vai dormir às 22 horas, após a novela, nos dias que não está na atividade de crochê. Na noite que realiza o trabalho artesanal, costuma dormir um pouco mais tarde: "seu eu estiver fazendo crochê às vezes eu enrolo até pouco mais".

O tempo de descanso é subvalorizado para dar lugar ao cumprimento do trabalho doméstico, considerando que esteja no período de gozo de sua aposentadoria. Dessa forma, 
para dar conta da rotina do trabalho doméstico, das atividades no CEU e outras tarefas que possam surgir no dia, a aposentada afirma que costuma acordar cedo, para poder conciliar as atividades no CEU e o Conselho Gestor com as atividades domésticas:

A coisa melhor que tem é você levantar cedo. Porque se você fica na cama até $8 \mathrm{~h}, 9 \mathrm{~h} 10 \mathrm{~h}$, seu dia já acabou. Então eu tenho que levantar cedo para mim dar conta de fazer tudo as minhas coisas. E o meu marido nunca disse para mim, você não vai hoje em tal lugar, você tem que ficar em casa para fazer isso e aquilo, não. A hora que eu chego eu faço. Porque se você levanta tarde, acabou o dia. Domingo se eu levantar 7 h30 já é tarde.

Em sua pesquisa, Cristina Bruschini (2006) passa a reconhecer que à medida que se eleva a idade das mulheres, eleva-se também o tempo gasto com as tarefas domésticas. Uma hipótese por mim aventada para esse crescimento diz respeito ao fato de que muitas mulheres de elevada faixa etária tendem a permanecer mais em casa, pela dificuldade de locomoção, problemas de saúde ou até porque seus laços sociais são menores por conta da idade. Dessa forma, ao permanecerem mais em casa, tendem a se envolver com mais intensidade nos afazeres domésticos.

Bruschini (2006) observa corretamente que na análise do tempo dispendido no trabalho doméstico "o cuidado com os filhos é uma das atividades que mais consomem o tempo de trabalho doméstico das mulheres", e "mesmo que as mais velhas, casadas e mães sejam precisamente aquelas que estão adentrando com mais vigor no mercado de trabalho e nela permanecendo" (2006, p. 347). Ainda conforme informações de sua pesquisa acerca do trabalho doméstico, a autora completa que:

Segundo os dados desta pesquisa, as mães dedicam aos afazeres domésticos quase 32 horas do seu tempo semanal, um número muito superior ao da média geral e mais ainda ao das mulheres que não tiveram filhos. Note-se também que, enquanto $95 \%$ das mulheres que tiveram filhos responderam que cuidavam de afazeres domésticos, $82 \%$ das que não tiveram filhos deram resposta semelhante (BRUSCHINI, 2006, p. 347).

Para a Mariana, é inconcebível despertar da cama depois das $8 \mathrm{~h}$ ou 9h, mesmo na condição de aposentada e não tendo mais filhos pequenos para cuidar. O destaque de seu relato fica por conta da importância que ela faz de uma rotina de acordar cedo, o que revela a incorporação e manutenção de um hábito feito ao longo de uma vida fora de casa, caracterizada pelo cumprimento de jornada com horário disciplinado imposto pelo ritmo do trabalho. 
Assim como Mariana, Lilian também mantém uma rotina de acordar cedo, um hábito cultivado, segundo ela, desde sempre, de forma que possa organizar previamente suas tarefas. O hábito de despertar prematuramente contribui para o cumprimento de todas as tarefas domésticas ao longo do dia. As primeiras atividades diárias de Lilian são o cuidado com os animais em sua casa, a lavagem do quintal para manutenção da limpeza, considerando os bichos de estimação que herdou, após o falecimento de sua mãe, além da lavagem das roupas. Assim como Mariana, nos dias de reunião do Conselho, ela dedica-se em cumprir agenda de compromisso exclusivamente:

Eu marco na minha agenda. $\mathrm{O}$ dia de reunião eu não pego outro compromisso. De manhã eu faço as minhas coisas em casa que eu tenho que fazer, cuido dos meus bichinhos, aí venho para as minhas atividades, aí volto para casa, faço meu almoço, faço o que eu tenho que fazer, já aviso em casa: "oh, vou sair dez horas da atividade, tenho reunião".

Lilian é a responsável pela chefia da família e pelos afazeres domésticos. Em 2016 e 2017, Lilian dividia moradia com sua nora e um dos seus três filhos. Durante esse período, Lilian contou ter sido a única responsável pelos afazeres domésticos, já que tanto a nora, como o filho e o marido trabalhavam fora de casa, sendo que a nora estudava após o expediente de trabalho. A dona de casa relatou que precisava se organizar mais para conseguir manter a rotina de atividades no CEU, e nos dias de reunião no Conselho Gestor, mantinha uma jornada diferenciada dos demais dias:

Mas assim, eu dava conta, levantando cedo a gente vai se ajeitando. Porque a reunião é uma vez por mês. Então eu já sei, aquele dia eu não marco consulta, aquele dia eu não marco compromisso. E a reunião é na quarta, a minha massagem é na terça, eu vou fazendo assim, vou me encaixando e com isso a semana passa e eu nem vejo.

O tempo dedicado aos afazeres domésticos, segundo Lilian, é praticamente integral. Embora não resida com a filha, a dona de casa é a responsável pela lavagem de roupa da neta, quando de sua visita, dentre outras atividades:

Menina, a gente em casa não para. Sabe para o que que eu paro? Depois do almoço assim, eu deito no sofá. Quando eu não tenho que sair eu deito e descanso um pouquinho. Porque casa é o dia inteiro. É um cachorro que faz não sei o que, você tem que cuidar. Eles comeram de manhã, na hora do almoço é o dia inteiro. É o dia inteiro. Que nem, segunda-feira minha filha veio e ela tem um bebezinho de quatro meses. Nesse dia não faço nada. Ela vem, eu dou atenção para o bebezinho, tudo para a gente não estragar, a gente adora estragar. Aí depois na terça-feira ficou a roupinha dele para lavar, é o dia inteiro. Se eu não pegar depois do almoço para descansar uns vinte minutos, aí só de noite. 
A aposentada chama atenção de como a dedicação ao trabalho doméstico e o cuidado para com os outros se sobressai em detrimento da redução de tempo dedicado ao cuidado de si:

Então, aí chega final de semana você está, que nem esse, eu fui no aniversário no domingo, lá em Franco da Rocha, sítio muito bonito. Aí na segunda minha filha veio, na terça eu fiquei limpando casa, e a gente se anula, a gente acaba se anulando para deixar tudo certinho para os outros, porque a gente se anula mesmo.

Renata, embora seja a única que não relatou experiência de trabalho fora de casa, é dona de casa desde os 17 anos de idade. Ela contou-me sua rotina intensa de trabalho doméstico, cuidado dos três filhos jovens e do esposo. Mesmo dividindo as tarefas domésticas com os filhos, acredita despender, aproximadamente, 12 horas diárias nos afazeres domésticos:

Eu acredito que umas doze horas, porque tem dia que você levanta as sete e você está até as sete da noite. E, olha, até mais, viu? Eu estico a jornada, dez.

Renata se considera a responsável pela chefia da família, mesmo que o marido seja o provedor financeiro do grupo familiar, e se intitula a "presidenta da empresa", e permite que seu marido possa administrar "um pouco" o poder de mando em casa, já que ele trabalha "muito" fora de casa, ficando ausente bastante tempo.

A conselheira Renata divide e gerencia os afazeres de casa com os três filhos. Como as responsabilidades são estipuladas previamente, a conselheira conta que todos os filhos possuem uma função na organização das tarefas e sabem de antemão quais são suas responsabilidades domésticas. O caçula, de oito anos, fica responsável por recolher os objetos fora do lugar em casa. Enquanto o outro filho de quatorze anos a auxilia nas tarefas de casa:

Eu falo: "Limpa isso, faz aquilo, vai no mercado, faz não sei o quê". Então, são divididas as tarefas sim. Uma casa é uma empresa, é o que eu falo e tem que ter alguém para administrar. Então, eu fui escolhida.

Com as reuniões mensais no Conselho Gestor, Renata se organiza para conciliar seu tempo no colegiado e nos afazeres domésticos. Até mesmo em casa, Renata recorre à gestão do CEU para encaminhar demandas, fora do espaço das reuniões mensais do Conselho:

Consigo conciliar e venho aqui. "Ah, não tem espaço". Às vezes, eu estou em casa e falo: "Não. Eu não vou engolir isso". Eu desço aqui e falo com a gestora, muitas vezes eu já fiz isso, de eu estar passando, eu vejo: "O que que está acontecendo?”. 
Não só para Renata, mas para todas as conselheiras, o trabalho doméstico é uma categoria central e, mais amplamente, devido às inúmeras conotações conceituais que geram dúvida sobre o significado que abarca o termo de "trabalho doméstico". Embora contemple os termos "produção doméstica, economia doméstica, serviço doméstico, atividade do lar, atividades domésticas, cuidadora de pessoas, dona de casa, mãe", a definição de trabalho doméstico, segundo Dominique Fougeyrollas-Schwebel (2009, p. 256-257), envolve um “[...] conjunto de tarefas relacionadas ao cuidado das pessoas e que são executadas no contexto da família - domicílio conjugal e parentela - trabalho gratuito realizado essencialmente por mulheres." São essas mulheres que organizam suas próprias rotinas de tarefas do dia a dia e dos outros, filhos e marido, para que em cada período do dia, elas possam realizar as tarefas correspondentes.

Em seu relato inicial sobre sua vida de dona de casa, Renata ressalta o gosto no cultivo de amizade, comunicação e convivência com outras pessoas. Mesmo que as tarefas domésticas a enclausure no espaço privado, ela destaca o prazer de estar entre outras pessoas e manter laços de amizade e de comunicação:

E minha vida em casa é normal, como de toda dona de casa. Eu tenho muita amizade, gosto muito de conversar, gosto muito de bater papo, gosto de falar, gosto de abraçar. Essa é a minha vida, essa sou eu.

A única entrevistada que concilia a jornada das atividades no CEU com os afazeres domésticos e os estudos é Nair. A conselheira afirma que nunca teve uma rotina fixa diária. Ela e o marido sempre trabalharam fora de casa com horários flexíveis, permitindo adequar a rotina:

Eu nunca tive uma rotina, lógico que eu sou uma pessoa bem responsável, tomo café da manhã, almoço, limpo a casa. Minha casa não é suja. Por exemplo, fui à casa da minha cunhada esses dias, e ela tinha um monte de bibelô, assim, na geladeira. Você imagina, assim, ela gosta de muitas coisas...

Nair explica como é a organização diária de sua rotina e da sua casa. Ela organiza a casa de forma a não a se prender na limpeza. A organização das suas tarefas domésticas está atrelada às suas atividades. Quando tem reunião do Conselho Gestor, organiza-se previamente e procura adiantar as tarefas de forma que elas não a impeçam de comparecer aos encontros, estratégia adotada também por Mariana e Lilian:

Tenho tantas coisas que eu procuro, assim, ter na minha casa de uma forma que ela não me prenda em questão a limpeza: como é que eu posso fazer isso de uma forma melhor? Como é que a gente pode fazer de uma forma melhor? Então, assim, se eu sei que eu tenho algo para fazer, eu não gosto de nada muito, assim, surpresa. Vamos supor: se você chegar 
na minha casa, "Ah, eu estou passando mal, me leva pro médico", eu largo tudo e vou levar você ao médico, pois tem uma coisa de urgência, de emergência. Mas se você me disser assim, "Olha, amanhã eu vou estar com você”, então eu já procuro adiantar as coisas de uma maneira que não vá atrapalhar muito a minha rotina.

Nair conta se sentir em "crise" com a obrigação dos afazeres domésticos. Ela questiona junto com sua filha o funcionamento do sistema patriarcal, que responsabiliza as mulheres pelos afazeres de casa, e reflete em como a "coisa foi pensada desse jeito." Muitas vezes realiza até onze horas, por dia, de trabalho doméstico. "Se eu brincar eu fico oito horas, dez e onze horas fazendo coisas na minha casa. Não pode ser.”

Nair chama atenção para a invisibilidade do trabalho doméstico e como essa situação proporciona vulnerabilidade das condições de trabalho, além da ausência normativa que deveria reger tal trabalho. Enquanto o trabalho doméstico não é reconhecido social e legalmente, dá brecha para o aumento dos riscos com sua saúde e segurança, ao contrário da condição do trabalhador formal, em tese:

Eu estou aprendendo hoje sobre biossegurança e eu falo para a professora: porque o trabalhador você tem que olhar o trabalhador lá no seu emprego, se ele ficar com movimento repetitivo, ele faz isso, não sei o quê, não sei o quê. Eu falei, espera aí, a mulher, ela está sujeita a todas essas coisas e a todas essas coisas e por quê? Porque realmente o trabalho da mulher nunca foi visto como um trabalho.

Os afazeres domésticos agem como uma "cortina de fumaça que obscureceu as formas de viver das mulheres", como mencionado em artigo por Hildete Pereira de Melo, Cláudio Monteiro Considera e Alberto Di Sabbato (2007, p. 438). Em artigo, propõem a medição do valor do trabalho doméstico pela teoria econômica e procuram trazer à tona o conceito de invisibilidade e inferioridade do papel das mulheres na sociedade, atribuída essa última à histórica discriminação vivenciada pelas mulheres nas várias sociedades. "Embora se tenha tido acesso à educação, trabalho assalariado, participação social e política", os autores observam que "as mulheres têm uma face voltada para o lar e a outra para a rua, num grande esforço de sobrevivência, num tempo de ruptura de um código milenar". (MELO; CONSIDERA; DI SABBATO, 2007, p. 436)

Nair coloca em debate todas as sujeições que as mulheres estão expostas no trabalho doméstico, assim como qualquer outro trabalho reconhecido: "Então eu falo, espera aí, professora, uma dona de casa, ela está sujeita a todas essas questões físicas, ergométricas." Segundo a dona de casa, o trabalho doméstico é realizado de acordo com as prioridades:

Então, por exemplo: se eu tenho que fazer isso naquele determinado momento, eu faço o que é prioridade. O que tem que fazer? Eu acredito 
que enquanto na minha caminhada de vida uma coisa que é básico é a alimentação. Eu fui aprendendo isso com a minha vida porque eu acho que roupa... Quem foi que criou essa cultura que você tem que ficar passando roupa? Meu Deus, isso é para quem não tem, assim...

Ludmila Costhek Abílio, ao estudar a forma de trabalho domiciliar das revendedoras de cosméticos, analisa o trabalho flexível executado pelas mulheres e que pode ser comparado com o trabalho doméstico à luz da informalidade. Para isso, a autora recorre ao conceito de "feminização do trabalho", que indica não somente o aumento da participação feminina no mercado de trabalho como também a adequação de características típicas do trabalho em domicílio", que progressivamente tem se tornado predominante quando da mulher inserida no mercado de trabalho. Tanto o trabalho de revenda de cosmético, quanto o trabalho desempenhado na esfera doméstica, além de não serem reconhecidos, são caracterizados pela indistinção entre tempo de trabalho e da ausência de regulações protetoras, segundo Abílio. (ABÍLIO, 2014, p. 87-88)

Nair questiona a desigual divisão de afazeres domésticos entre homens e mulheres por detrás da indignação do excesso de tarefas domésticas:

E por que que tem que ser assim? Por que que a sua energia... Não quer dizer que você não possa passar uma roupa, mas viver, assim, desta forma, tem coisas tão mais importantes, tão mais pontuais na vida de um ser humano...

Por isso, pretende fazer recomendação à filha e aos netos para que mudem a educação e a forma de viver em casa:

Eu fico pensando, eu não quero, sinceramente, eu não quero que a minha filha... Se eu puder, assim, passar algumas coisas para minha filha, mais pontuais, para os meus netos, eu não vou passar essa maneira de educar dessa forma. Acho muito, muito, muito errado e eu estou tentando, na minha vida, agora, nesses últimos... porque eu já não tenho tanta força, eu tenho uma idade... Eu estou com cinquenta e cinco anos. Você não tem tanta força, como você tinha antes. Para que eu não me perca nisso, eu não quero viver para casa eu quero viver na casa.

Além de propor outra forma de educação, o que parece sugerir uma responsabilização equitativa das atividades domésticas entre os gêneros, no trecho anterior, Nair também propõe outra forma de organização das atividades domésticas, considerando o avanço tecnológico dos aparelhos eletrodomésticos, realidade distinta vivida nas gerações anteriores:

O importante é entender que você pode fazer de uma forma diferente, não tem que ser da forma que a sua vó, que a sua mãe. Você pode pensar, 
porque tudo mudou, tudo mudou. Se hoje você tem a máquina de lavar, por que que você fica tanto tempo? Você está entendendo?

Nair apresenta uma reflexão a partir da análise do trabalho doméstico, quando argumenta a transformação pela qual as mulheres estão passando. Uma transformação que ela pretende educar as mulheres de uma forma diferente, a fim de que possam se desapegar dos afazeres "como o reinado" delas. Como é a única que concilia trabalho doméstico com estudo, sua reflexão expõe seu dilema diário. Acredita que as mulheres têm dificuldade de "dividir, delegar e pedir ajuda", possivelmente motivadas "por uma questão de sobrevivência":

E aí, se eu perder isso aqui? Ninguém mais vai depender de mim; eu não vou ser a dona do lar, dona da casa? Então, eu vejo que é uma questão, também, de psicologia da mulher. Ela, em torno de tudo isso que está acontecendo...

O conceito de performatividade de Judith Butller pode ser tomado para explicar a passagem acima de Nair. O efeito que produz a identidade de mulher e dona de casa não é resultado de uma representatividade semelhante a uma encenação do seu papel de mulher no espaço doméstico, mas são relações de gênero que se reiteram ao longo do tempo, baseada na repetição sobre o que é ser mulher e dona de casa. O efeito da repetição de corpos, linguagens e gestos funciona como resultante das ações reguladoras cotidianas naturalizadas no espaço doméstico, que confere, portanto, a manutenção da ordem dos papeis de gênero:

O gênero está condicionado por normas obrigatórias que o fazem definirse em um ou outro sentido (geralmente dentro de um marco binário) e, portanto, a reprodução do gênero é sempre uma negociação de poder. Finalmente, não existe gênero sem reprodução das normas que ponham em risco o cumprimento ou o descumprimento de tais normas, abrindose, desse modo, a possibilidade de uma reelaboração da realidade do gênero através de novas formas. (BUTLER, 2009, p. 322)

Márcia Aparecida Gobbi, ao analisar o papel social da mulher, ao longo das décadas, observa que havia uma tendência nos estudos em acreditar que o "poder exercido pelas mulheres" era "ilegítimo ou menos importante" (GOBBI, 2016, p. 86). Poder esse que era exercido, predominantemente, no espaço doméstico. Ao contrário desse pensamento, os estudos atuais tomam mulheres e homens como "categoriais socialmente construídas, resultado de uma intrincada rede de significações sociais” (GOBBI, 2016, p. 86). Segundo Coutinho (1994), conforme citado por Gobbi (2016, p. 87), ao observar o exercício do poder da mulher no espaço doméstico da casa e junto à família, a autora nota 
uma rede de ordens e vigilância doméstica que, muitas vezes, extrapola ao espaço público, na relação de mãe, filhos e marido:

Confinadas por séculos no espaço da casa, onde reinavam quase absolutas, enfeitiçando maridos e filhos com a máscara da perfeição, as dedicadas e abnegadas mães e esposas encontraram formas especiais e silenciosas de articular sua resistência, em murmúrios que se perdiam, muitas vezes, no corpo forte dos homens que as sufocavam. Nem vítimas nem algozes, acreditamos que as mulheres ao longo dos anos foram tecendo modos de resistência a esta opressão masculina. (COUTINHO, 1994, p. 19)

Como dito, essa teia organizativa doméstica tem sua lógica de funcionamento, construída por meio do discurso e de ações que reforçam a imagem sobre as mulheres. (GOBBI, 2016). Como sugere Joan W. Scott, a análise da linguagem é o ponto de partida da construção de significados, no entendimento das instituições e a forma como se organiza o trabalho das mulheres. (SCOTT, 1992). Essa linguagem sendo dita ou não, entendida ou subentendida, é responsável pela construção da identidade e das relações de poder. Se essa nomeação atua de modo pejorativo para o atributo de gênero ou idade, tende a criar hierarquia, que chancela a desigualdade no interior doméstico. Maria Cristina Cavaleiro, ao abordar Scott, observa que a construção da narrativa que ocorre no espaço escolar corrobora na construção da desigualdade a partir do entendimento de que a natureza dos meninos é incontrolável, ao contrário das meninas (CAVALEIRO, 2009).

Com o advento da modernidade, as atribuições das mulheres ligavam-nas à doçura, ao recato e ao comedimento, cujas ambições não extrapolavam ao território doméstico (GOBBI, 2016). A construção social feminina se alicerçou sobre características subordinadas, conforme a socialização tradicional de gênero. Mesmo com a saída da casa para a rua, as características que sempre estiveram atribuídas à mulher no espaço doméstico se mantêm. Quando a mulher ocupa espaços participativos na esfera pública ainda passa a ser vista com a lupa de um local a que sempre lhe foi atribuído e domesticado. Passa a acumular dupla, tripla ou mais função social, sem que as estruturas familiares e sociais se modifiquem.

Embora ao longo da entrevista Nair valorize, recorrentemente, a comunicação, na sua fala a seguir, pontua os contratos não verbais estabelecidos com o marido, relacionados à divisão do trabalho doméstico: "a gente se comunica de uma forma sem se comunicar. Não tem nada assim muito estabelecido". Relembra que ambos realizam o trabalho doméstico "que tem que fazer", sem que "fosse algo muito sistemático". E finaliza: "cada 
um foi entendendo o que tinha que fazer." Esse ponto parece importante em sua fala. Tem consciência das formas de controle e poder do patriarcado.

Sinônimo de "dominação masculina", a definição de patriarcado, segundo Christine Delphy, diz respeito a "uma formação social em que os homens detêm o poder, ou ainda, mais simplesmente, o poder é dos homens" (DELPHY, 2009, p. 173). Como sua filha é criada de um modo que "ela não tem que servir" o homem, seja o pai ou o marido, Nair poupa sua filha de servir seu pai, sem ter a necessidade:

A minha filha entende que ela não tem que servir, tipo assim, como que eu posso falar, meu Deus? Se o marido. É uma coisa que ela sempre pediu para mim, ela falou, "Mãe, não me peça para servir o pai com ele sentado no sofá. Não faça isso comigo. Eu acho um imenso... É uma pessoa está sentada e ter que servir outra sem ela ter necessidade.

Há um esforço de Nair em evitar que a filha se submeta ao pai, assim como há o desejo da filha em não entrar nessa lógica patriarcal e sexista:

Ela fala assim, "Não me faça fazer isso, não me faça; eu acho muito... Eu não vou fazer isso". Se eu quiser servir ele, eu vou servir, mas na mesma proporção que ele também..., "Mas não me faça isso".

Raewyn Connell e Rebecca Pearse (2015) apresentam as quatro dimensões da estrutura das relações de gênero (poder, produção, catexia e simbolismo), que são importantes ferramentas de análise na compreensão da questão levantada por Nair. Mesmo que na ausência do poder, representado pela figura do pai, marido ou do Estado, a divisão sexual do trabalho determina quais tarefas podem ser realizadas por homens e mulheres. Já as afetividades e vínculos emocionais conectam pessoas por meio do discurso: "quando falamos em 'uma mulher' ou 'um homem', ativamos um imenso sistema de entendimentos, implicações, sobretons e alusões que se acumulam ao longo de nossa história cultural”. (CONNELL, 2015, p. 172)

\subsubsection{Resolvi estudar e fui estudando, aí sofri um problema de saúde que me atrapalhava de estudar}

Pensar a escolarização na vida dessas mulheres é fazer referência a duas dimensões opostas, mas intimamente relacionadas em suas vidas: a importância da educação, por um lado, e os obstáculos e dificuldades em acessar à escolaridade, por outro.

Cada uma das entrevistadas tratou sobre a importância da educação de uma forma. Mariana manifestou desejo de ter curso superior em Administração de Empresas, enquanto Lilian passou a lutar pela educação do filho no bairro. Renata possui o ensino médio completo, enquanto Mercedes se preocupa com a péssima condição de creche conveniada 
da Prefeitura, instalada em sua rua: "Eu não gostaria de ver minha neta nessa creche. É um sobrado, de uns quatro andares. Mas é muito...".

Nair, a única das cinco que cursava o ensino superior, expressa sua admiração pelo trato educado de seu professor:

Eu acho tremendo, isso. E ele tem uma formação, assim, que eu fiquei até assim, nossa. Eu posso ser vó dele, mas uma educação, uma educação bonita, a maneira que ele fala.

Todas as cinco conselheiras viveram a experiência da saída de casa para a escola. Mariana não concluiu o ensino fundamental, e Lilian cursou quatro anos (de cinco) do "primário", que corresponde ao ensino fundamental I na atualidade. Renata e Mercedes possuíam, ao menos, o ensino médio, sendo que Mercedes chegou a cursar o ensino superior durante três meses. Somente Nair cursava o ensino superior de Nutrição em faculdade particular no momento da entrevista. Mariana, Mercedes e Nair foram as entrevistadas que fizeram relatos aprofundados acerca da escolaridade.

Essas histórias confirmam que, embora o direito à educação seja uma garantia de longa data, o sistema educacional brasileiro passou a acomodar as mulheres somente a partir de 1940, o que impactou em altas taxas de analfabetismo no grupo de mais idade, principalmente entre as mulheres das camadas menos abastadas (ROSEMBERG, 1993).

Esse é o caso de Mariana. Ela lembra que quando chegou em São Paulo, sabia somente escrever o nome. Não concluiu o ensino fundamental, pois sofria de labirintite. Caso o problema de saúde não a tivesse impedido de prosseguir seus estudos, contou que sonhava em cursar o superior em Administração de Empresas:

Aí em 1995 eu resolvi estudar, comecei da primeira série e fui estudando, aí quando eu estava na oitava aí eu sofri um problema de saúde que me atrapalhava de estudar. Eu conversei com o professor de história e ele falou assim, 'olha se for para você ficar nessa situação aqui na classe é melhor você parar de estudar porque você não está bem, não tá conseguindo pegar as matérias'. Aí eu conversei com ele, professor e ele falou assim: eu aconselho a senhora a parar, dar um tempo. Agora você sabe que depois de parar perde a vontade, não tem mais aquela vontade. Aí parei dei um tempo. E agora tem dois anos que não estou sentindo mais. Foi um maldito labirintite que atrapalhou minha vida. Mas quando eu estava estudando, eu falava se eu conseguir estudar eu vou fazer uma faculdade, administração de empresas.

Aos 61 anos de idade, Mariana conta que prosseguir nos estudos está fora dos seus planos: "Mas agora não tenho mais vontade não, vou fazer 62 anos. Não quero mais assim um compromisso não. Eu quero só o que eu sei mesmo por que o que eu sei é viajar, descansar minha mente". 
A estratégia de conciliar o papel de dona de casa, usuária do CEU, mãe, esposa com os estudos não é tarefa fácil. Nair, conta do conflito na conciliação dos afazeres domésticos com o atual curso em andamento no ensino superior. "Para eu estudar está sendo muito difícil para mim sair de casa e deixar a louça sem lavar."

Dentre os quatro tipos de modelos de conciliação de vida familiar e profissional (modelo tradicional, modelo de conciliação, modelo de parceria e modelo de delegação) observados por Helena Hirata (2007), o primeiro se aproximaria da realidade de divisão sexual do trabalho experimentada por Nair, cuja característica é quando "a mulher não trabalha fora, assumindo cuidados da casa e dos filhos, e o homem provedor." A escolarização é pensada para modificar a configuração das atribuições domésticas, mas para conceder autonomia às mulheres na realização das atividades cotidianas sem dependência, com o rompimento da relação de submissão (NOGUEIRA, 2002).

Nair fala da resistência que impede que as mulheres larguem as tarefas para realizarem outras atividades: "tem um domínio muito forte". E faz uma reflexão sobre as mulheres a partir da sua experiência como estudante e dona de casa:

E às vezes eu saio de casa, assim, eu fico assim: eu tenho que fazer uma matéria, eu fico estudando, assim, aí eu olho para pia, e a minha filha até falou para mim, "Ó', mãe, vou dar uma dica para a senhora, vai para faculdade porque se a senhora não fizer isso, a senhora não vai conseguir". Então tem um domínio muito forte.

Lilian faz observação lembrando que o antigo primário que cursou, embora de quatro anos, foi mais completo que o ensino médio da atualidade: "Posso fazer um comentário? No meu tempo, em quatro anos você aprendia coisas muitas, você aprendia os ossinhos, nome dos dentes, você aprendia muita coisa".

Ao relatar sua dificuldade na leitura do regimento interno do Conselho Gestor, Mercedes compara a leitura do documento à leitura de uma receita médica, de difícil acesso. Tanto o receituário médico quanto o regimento interno do Conselho Gestor do CEU são avaliados da mesma maneira e negativamente. Outra dificuldade encontrada em acessar à educação, observada em seu relato, foi a permanência no ensino superior devido às condições financeiras:

Menina, mas você lê, é que nem receita médica... (risos). Muitas coisas porque eu sou assim, eu sempre fui, sabe? É se eu estou na internet, se eu vou digitar alguma coisa, eu não tenho, eu não sou formada, assim... eu não fiz faculdade, universidade, nada; já tentei, entrei na época, na Mackenzie, fiquei três meses, só, e caí fora porque não tinha condições de pagar. 
Mercedes prossegue ao observar dificuldade no acesso à tecnologia quando faz a leitura por meio do computador:

Mas, eu fico muito nervosa quando eu estou, assim, na internet e tem alguém... por isso que eu sou meio limitada com internet; celular também, eu não gosto. Porque eu odeio, quando as pessoas, quando começam a ler alguma coisa, está tudo errado, menina, ou está tudo é, simplificado.

E comenta da dificuldade de entendimento das palavras e de sua necessidade de recorrer ao uso do dicionário quando acessa ao computador:

Que eu mesma, quando me bate, nossa, eu falei, eu vou lá no dicionário e tento, entendeu? E esse negócio, assim, você pega e começa a ler, se tudo for, ali, perguntar e tudo, e for tentar entender mesmo, é difícil. E é, são muitas páginas. Então é mais fácil uma pessoa que realmente entende, ir lendo e explicando.

Os depoimentos revelam a dificuldade que essas mulheres encontram ao acessar os degraus da educação formal, seja a barreira de um problema de saúde que a impede de frequentar as aulas, como Mariana, ou quando conseguem acessar, esbarram na responsabilidade desigual dos afazeres domésticos ou da própria dificuldade financeira de custear um ensino superior, como Nair e Mercedes relataram.

\subsubsection{Ainda faço um trabalho que a minha filha trabalha numa fábrica de pulseiras}

O tema do trabalho nos estudos feministas se mostra importante para revelar a desigualdade de gênero pela qual o trabalho das mulheres é invisibilizado e desvalorizado. Desde criança, as meninas e os meninos são criados para o cumprimento e reprodução da divisão sexual do trabalho, que restringe às meninas no espaço privado, enquanto destina aos meninos o treinamento com a desenvoltura de atuação no espaço público. No espaço privado, cabe a elas o cuidado com filhos, marido, familiares e afazeres domésticos e, quando inseridas no mercado de trabalho, as mulheres tendem a ocupar cargos e posições inferiores e sem prestígio, repetindo a sina de sua criação.

Aquelas que não estão inseridas no mercado de trabalho formal acumulam rotina de trabalho intenso dentro de casa. Já as mulheres que viveram a experiência de sair de casa e atuarem no mercado de trabalho trazem na bagagem experiência de relações pessoais e sociais distintas da experiência vivenciada no universo doméstico.

Quando solicitada a relatar um pouco de sua trajetória no mercado de trabalho, antes de entrar no Conselho Gestor do CEU, Mariana começa a contar que trabalhava fora, em uma empresa: "antes de entrar no Conselho Gestor eu trabalhava em empresa, eu trabalhava 
fora". Já aposentada e usuária das atividades do Centro Educacional, passa a organizar sua rotina de tarefas domésticas com as atividades no CEU e outras tarefas que possam surgir no dia a dia.

Essa realidade é descrita por Heleieth Saffioti ao ressaltar as novas dimensões da dinâmica social vivida pelas mulheres com a intensificação da urbanização e a industrialização, "não porque a mulher tivesse passado a desempenhar funções econômicas, mas em virtude de se terem alterado profundamente os seus papéis, no mundo econômico". Mesmo que o "trabalho nas fábricas, nas lojas, nos escritórios" tenha rompido "o isolamento em que vivia grande parte das mulheres, alterando, pois, sua postura diante do mundo exterior" (SAFFIOTI, 1976, p. 179), coube a elas a responsabilidade do acúmulo de afazeres, agora não mais no espaço privado, mas também nas tarefas propriamente do espaço público.

Por outro lado, o trabalho manual do crochê, feito no espaço privado, representa para a Mariana o momento de "passatempo" diante de uma rotina intensa de afazeres dentro e fora de casa:

Geralmente depois de terminar a novela eu vou dormir. Às 22 horas e pouco, se eu não estiver fazendo crochê, já se eu estiver fazendo crochê, às vezes eu enrolo até pouco mais.

O resultado desse "passatempo" dedicado à atividade manual de crochê é aproveitado por Mariana para a comercialização de produtos artesanais durante os dias de festividades no CEU:

Então, eu venho no show, quando tem festa no CEU, eu monto minha barraca, de pão, às vezes eu coloco os meus trabalhos artesanais.

Nota-se que até o momento em que seria dedicado ao descanso em casa, após um dia de trabalho, é utilizado para o trabalho manual e, quando tem a oportunidade de comercializar seu artesanato nos eventos do CEU, a conselheira considera como um momento de lazer. Isso revela uma dificuldade de Mariana em separar o tempo para o nãotrabalho.

Lilian inicia a entrevista afirmando que sempre trabalhou fora de casa e criou os filhos sozinha. Essa afirmação é realmente importante para a pesquisa, pois coloca em evidência o tema do trabalho remunerado exercido pela conselheira, antes de atuar no CEU, e a importância com que o tema do labor aparece ao longo de sua fala.

As práticas sociais, no âmbito da reprodução simbólica, como o cuidado dos filhos, contêm um componente de reprodução material, que é o trabalho invisível das mulheres; 
trabalho esse crucial para a vida econômica, que se cristaliza também no espaço público, via mercado de trabalho (FRASER, 2015, p. 44). Entretanto, muitas delas são as únicas responsáveis pela família como Lilian.

Para Lilian, sua identidade de trabalhadora responsável pela criação dos seus filhos sem ajuda do marido, diante da adversidade de seu problema de saúde, significa uma trajetória de sucesso. Antes da aposentadoria, trabalhava fora de casa, com carteira de trabalho assinada. O sentimento do orgulho por ter conseguido vencer na vida, de ter trabalhado arduamente, dentro e fora de casa, e ter sido a responsável pela criação dos filhos, mesmo diante das adversidades, dão o tom da entrevista de Lilian:

Eu sempre trabalhei fora, criei meus filhos, e depois quando eu vim para cá eu já tinha tido o problema de saúde, aí eu fui para minha casa e nisso eu aposentei.

O destaque conferido pela conselheira ao trabalho fora de casa, em um contexto adverso de falta de estudos aliado ao esforço pessoal, revela a importância que a trajetória profissional teve na vida de Lilian. O significado de sucesso para a conselheira é a própria trajetória percorrida após anos de muito trabalho em uma empresa de grande porte como a Siemens ${ }^{10}$, no bairro da Lapa, e o esforço na busca por qualificação para, finalmente, a recompensa da aposentadoria:

Mas eu acho assim, olha, eu não tive estudo não. Eu não estudei nada assim, o pouco que eu aprendi foi trabalhando. Eu sempre assim, nunca fui de me acomodar, eu sempre fui trabalhando. Na minha época que eu era mocinha, tinha curso de datilografia era top de linha. E eu ganhei muito dinheiro, trabalhei muito na minha vida com datilografia, e foi indo, eu aposentei na Siemens, eu fui indo.

Lilian revela o valor do aprendizado por meio do trabalho e não unicamente pelo estudo. Sua resposta, após minha provocação, mostra que nega a comodidade e o conformismo, valorizando o trabalho. Os frutos de seu trabalho ela traduz nas seguintes passagens: "ganhei muito dinheiro" e "me aposentei na Siemens".

Divorciada, relata sempre ter sido a responsável pelo sustento do lar, com exceção, dos alimentos, de responsabilidade financeira do atual companheiro, com quem divide a casa desde 2012. Ainda antes do divórcio, foi a única responsável pela construção de sua casa. Sobre a gestão dos afazeres domésticos, Lilian conta:

Sempre fui eu quem paguei tudo. Sempre fui eu. O que ele faz é pôr um alimento dentro de casa, coisa de comida, de mistura, de feira. O meu

\footnotetext{
${ }^{10}$ Siemens Aktiengesellschaft ou Siemens AG, é o maior conglomerado da Europa e um dos maiores do mundo. Tem sede na Alemanha, nas cidades de Berlim, Munique e Erlangen
} 
marido. O meu filho nunca ajudou em nada, nem minha nora, então sempre foi ele na parte de alimentação e eu sempre com água, luz, telefone, tudo eu. A casa quem fez fui eu, porque ele está comigo agora, mas eu sou divorciada. Ele está comigo tem seis anos. Mas nessa época era tudo eu.

Lilian viu o CEU nascer. Relembra o bairro no período anterior à construção do CEU, em 2003, e da época em que ainda não havia sido construída a estação de trem Vila Aurora, em 2013. Seu relato denuncia a carência de políticas públicas de transporte, educação e de pavimentação, no seguinte trecho, e as dificuldades enfrentadas quando trabalhava fora de casa:

Aí foi povoando, aí veio o CEU, aí veio a estação, sabe, aí melhorou muito, porque aqui não tinha nada. Nossa, eu lembro quando eu trabalhava e chovia, a gente saía com um saquinho no pé, tempo de barro, foi bem sacrificado, mas eu consegui.

Teresa Caldeira descreve o processo de chegada do movimento migratório nas periferias de São Paulo. À medida que as pessoas chegavam à cidade, em meados dos anos de 1970, ela se transformava no centro industrial que não comportava o domicílio dos trabalhadores urbanos:

A alternativa era comprar pequenos lotes em áreas não urbanizadas em periferias distantes e erguer por conta própria as próprias casas num longo processo de construção e expansão que transforma minúsculas habitações em casas de vários pisos e cômodos. (CALDEIRA, 2014, p. 86)

A homogeneização do processo de urbanização, segundo Caldeira, que resultou no "padrão urbano centro-periferia" evidenciou-se em São Paulo em meados da década de 1970: "as camadas mais altas residiam em áreas centrais com boa infraestrutura e serviços urbanos, ao passo que os trabalhadores pobres moravam nas periferias precárias que eles próprios construíram”. (CALDEIRA, 2014, p. 86)

Nair conta já ter sido moradora de outro bairro antes de se mudar para onde mora atualmente e relata sua percepção sobre a diferença de como as mulheres trabalhadoras e moradoras dos dois bairros enfrentam a vida. Mesmo se tratando de um olhar fora do espaço do Conselho Gestor, é interessante notar como a conselheira enxerga as moradoras de bairros distintos e traz essa observação para a entrevista. Para ela, as mulheres da Freguesia do Ó, bairro territorialmente mais próximo do centro de São Paulo se percebiam ser moradoras de um bairro distante do centro, de difícil acesso e faziam questão de se deslocar com a necessidade de um automóvel. Em sua experiência junto as essas moradoras, Nair percebia que as mulheres do outro bairro, mesmo com a relativa localização privilegiada, 
acentuavam em suas falas enfrentarem mais obstáculos do que as moradoras de seu bairro atual, na periferia:

Eu percebo que as mulheres vão mesmo à luta, pegam as suas crianças de manhã, deixam aqui no CEU. Eu não sei se é a escola ou o lugar aqui onde estou, que faz com que eu veja muito isso. Aí eu vejo essa mulher daqui a pouco descer, pegar um trem, e vai trabalhar, daqui a pouco eu olho, à tarde, eu a vejo subindo para fazer o EJA. Então eu acho isso tremendo, assim, acho, assim, muito legal. Eu acho as mulheres muito fortes.

A experiência de Nair no espaço público, quando trabalhava fora de casa, antes de chegar ao Conselho, a fez compreender de sua responsabilidade educativa e social para com as pessoas, principalmente as de menor poder aquisitivo. Nesse encontro com a "deformidade", a fez perceber e ter contato com pessoas deformadas tanto fisicamente quanto pela vida:

Eu via que as pessoas ali, elas eram muito limitadas, por não serem alfabetizadas na forma de se expressar. Eu entendia isso, porque, por exemplo, você falava assim para pessoa: "o senhor vai no médico, o senhor pega a primeira direita, aqui, e o senhor sobe, depois o senhor pega a esquerda". A pessoa ficava assim olhando para você e não saía do lugar.

Nem sempre as mulheres ocupam postos de trabalho qualificado com carteira de trabalho assinada, e entre as entrevistadas não foi diferente. Normalmente os vínculos de trabalho destinados às mulheres são caracterizados pela informalidade, subempregos, precarização, baixos salários e a desproteção, e muitas dessas condições são, prontamente, aceitas como estratégias adotadas pelas mães para a dedicação no cuidado e criação dos filhos. A trajetória profissional de Mercedes passa pelo mercado formal e informal de mão de obra, e em sua fala ela também destaca a importância do trabalho em sua vida e a construção de sua identidade de trabalhadora:

Primeiro que eu sempre vivi em crise, querida, e esse negócio de crise, aí, para mim, eu sempre vivi em crise, meu marido sempre foi assalariado, eu sempre tive que ter muita noção do que eu ganho, porque isso eu sempre soube e eu sempre soube quem eu sou. Eu acho que é importante você entender quem você é e é isso que eu percebo que as pessoas não sabem, o jovem não sabe, ele não sabe onde ele está, ele não sabe quem ele é. Essa falta de identidade faz com que você. Então meu marido sempre ganhou muito pouco, sempre fomos assalariados e então a gente sempre conseguiu viver de uma forma em crise. Então a gente vive em crise. Tipo, olha: eu não posso ir além disso; além disso não dá, esse passo não dá para mim, entendeu? Então esse negócio de crise não me assusta. 
Além do exercício do trabalho doméstico não remunerado em casa, Mercedes faz um "bico", ao se dedicar também ao trabalho eventual informal, como forma de faturar "uns troquinhos":

E ainda faço um trabalho que a minha filha trabalha faz numa fábrica de pulseiras. É artesanato, com maquinário e tudo mais, e ela trabalha lá, como autônoma. E ela traz essas pulseiras para eu estar fazendo em casa também.

O trabalho informal é uma realidade na vida das mulheres, principalmente entre as trabalhadoras periféricas que encontraram obstáculos ao longo de sua vida na busca por qualificação e escolaridade. Segundo Abílio, a condição de informalidade é "a expressão de aprofundamento da desigualdade social, uma solução precária escolhida face ao desemprego e dos baixos rendimentos do trabalhador" (ABÍLIO, 2014, p. 73) Ainda segundo essa autora, as "desregulações do trabalho formal tornam ainda mais difíceis o reconhecimento da informalidade e a sua definição" (ABÍLIO, p. 74)

Abílio (2014) trata do conceito de informalidade relacionada à desigualdade social, tendo em vistas os inferiores salários e a qualificação. Assim como o conceito de gênero (SCOTT, 1995), o "processo de informalidade" é entendido como aquele que "possibilita a compreensão de algo que está em movimento, deslocando categorias de análise”. Mas à medida que o trabalho formal vem sendo atualizado e perdendo a regulação que anteriormente era referência de fonte de medida, ocorre a dificuldade de reconhecer o trabalhador nas reconfigurações em processo (ABÍLIO, 2014, p. 76-77) Abílio denomina de "viradores" e "viradoras", trabalhadores e trabalhadoras que passam de empregados a desempregados e depois à posição na ocupação de "conta própria", que abrangem os “autônomos" quando desagregados em sua categoria (ABÍLIO, 2014, p. 73-74).

Desde 2000 eu não trabalho mais, assim, registrada. Daí eu trabalho em casa. Eu, logo que surgiu o CEU, eu sempre participei da parte de esporte. Meu marido sempre trabalhou. Mas, com os filhos pequenos, daí eu tentei conciliar os horários.

Para assegurar a sobrevivência do grupo familiar, Mercedes se vê obrigada a passar por uma experiência de mudança no mercado de trabalho formal para o trabalho informal. Por conta dos filhos pequenos em idade escolar, vê-se obrigada a desempenhar o trabalho doméstico. Entretanto, para Vicki Schultz (1992), não se trata de uma escolha. Ela "questiona a afirmação de que as mulheres querem postos inferiores "por sua própria escolha", e não como parte de um processo cultural de predeterminação do que são os atributos das mulheres. Schultz critica ainda o fato de os tribunais terem assumido como 
premissa que o interesse das mulheres no trabalho é configurado exclusivamente por sua vida privada, independentemente das exigências do mundo do trabalho." (apud LUIZA HEILBORN; RODRIGUES, 2018, p. 16)

Também cabe lembrar que a adoção da estratégia de opção do trabalho domiciliar em detrimento do trabalho formal por Mercedes aventa a possibilidade de a escolha ser motivada pela necessidade de se manter presente na educação dos filhos e filhas menores, mesmo que a contrapartida seja de uma remuneração inferior. Teresa Pires do Rio Caldeira (1984), ao abordar o tema, afirma que não se trata de uma escolha de livre arbítrio das famílias, mas que "num certo sentido, elas têm limites impostos pela própria composição do grupo doméstico, pelas características do mercado de trabalho e pelas condições de remuneração que nele encontra cada um de seus membros”. Então, as famílias podem colocar na balança suas escolhas a partir das condições de vida.

A troca do trabalho formal pelo informal, além de eliminar a estabilidade e as garantias, confere ao trabalhador a diminuição da renda familiar, mesmo que outro membro da família esteja inserido no mercado de trabalho, como lembrou Mercedes.

Cabe entender a realidade com que as mulheres periféricas convivem diariamente. A dificuldade das mulheres em acessar ao espaço público exclui em maior grau determinadas mulheres, dependendo de marcadores sociais de diferença, como é o caso de Mercedes, que se identifica como negra. Tal análise desenvolvida por Helena Hirata mostra que as mulheres negras predominam em ocupações consideradas precárias, "de menor prestígio e de más condições de trabalho" (HIRATA, 2014, p. 64). A maioria delas travam uma vida de muito trabalho invisível dentro e fora de casa. Isso porque convivem com duplas, triplas e quádruplas jornadas de trabalho sem registro em carteira, o que não garante a elas direitos previdenciários.

\subsubsection{Sempre gostei muito de participar, participação ativa, de ajudar, também, sabe?}

A partir da caracterização dessas mulheres, no momento de saída da casa para a rua, busco captar o significado da participação, em uma tentativa de compreensão das fronteiras simbólicas do cotidiano que permeiam o processo da participação. Procurei estar atenta para a dimensão pedagógica da participação no CEU, como observado no estudo de Maria Luciana Brandão Silva sobre as mulheres bordadeiras de Ipatinga. Embora a autora reconstitua a atuação da associação de mulheres, de 1975 a 1980, o estudo, ao privilegiar a "análise das experiências vividas" no espaço da Associação de Mulheres do Bairro Bethânia, também compreende o processo educativo por detrás da vivência das mulheres 
nas atividades artesanais. Mais do que aprender e dominar a arte do bordado, o aprendizado das mulheres desenvolve-se nas "relações que elas estabelecem entre si e com os outros, no grupo e fora dele, forjando novas concepções sobre suas vidas em casa e fora dela". O estudo das mulheres do CEU mostrou que as participações delas no Conselho Gestor também influenciam suas vidas, coloca em evidência os aprendizados participativos como parte do processo educativo, "desencadeados mediante as diferentes formas e níveis de participação das mulheres nos grupos”. (SILVA, 2010, p. 22)

A experiência de participação no espaço público das mulheres conselheiras entrevistadas não está limitada à saída para a escola e ao mercado de trabalho assalariado exercido fora das paredes do lar. Os depoimentos das experiências de atuação junto ao espaço público também passam por vivências anteriores para além do espaço institucionalizado. E para pensar a participação das mulheres no espaço do Conselho Gestor do CEU, é relevante a análise da história pregressa de participação na vida das mulheres conselheiras. Para tal empreitada, vale o destaque de suas narrativas sobre suas trajetórias políticas e afetivas que compõem construções sobre passados, histórias e memórias no espaço público, desde suas referências familiares de participação política passando também pelas experiências familiares e de vizinhos no apoio aos pares.

A conselheira Nair lembra uma trajetória de participação com referência ao período de sua infância, quando a pessoa responsável por sua criação, enquanto sua mãe trabalhava fora, era de mais idade e de fora do grupo familiar. Nesse caso, entende-se a vivência na criação, exercida por pessoas de mais idade e não pertencentes à família, como um tipo de participação, predominante nas comunidades. A fim de assegurar a sobrevivência e subsistência do grupo familiar, muitas famílias adotam estratégias de compartilhamento solidário na criação dos filhos.

Tendo como base o trabalho de campo, foi possível verificar tanto a existência de referências familiares (pai e companheiro) de incentivo à participação ao longo da trajetória das conselheiras, como para Mariana e Mercedes. Também me foi possível observar como as referências de apoio e de solidariedade entre os pares serviram como relevante bagagem para a atuação das mulheres no espaço público, como mencionado por Nair. Cláudia Fonseca trabalha com o conceito de estrutura familiar matrifocal, cuja prioridade ocorre entre o laço de mãe com crianças e irmã e irmão, em detrimento do laço conjugal, considerado "menos intenso afetivamente" (FONSECA, 2004, p. 64). Fonseca observou que além da solidariedade de mulheres existia uma rede familiar de apoio formada por homens "relativamente prósperos". (FONSECA, 2004, p. 65) 
Nair começa a entrevista destacando que o seu entendimento de educação abarcou sempre a noção de compartilhamento e troca, além da responsabilidade ao próximo, de forma que as experiências profissionais que antecederam a sua participação no Conselho Gestor a fizerem entender desse seu dever. Sua experiência de participação não se limita à inserção profissional, mas ao período de sua criação, pois quando menina vivenciou relações de solidariedade com a vizinhança, denominada por ela como "educação de compartilhamento", que nada mais seria a educação cujos "vizinhos olhavam a gente". Essa forma de educação a fez compreender a importância do respeito ao próximo, normalmente, pessoa de mais idade, responsável pelos menores na ausência do pai ou da mãe. Portanto, o entendimento de participação comunitária para Nair é a compreensão de que o sujeito é "parte dessa comunidade":

Minha educação. Olha é puxa vida! Foi uma coisa assim meio natural, assim; a gente tinha... Primeiro que a gente brincava muito. Tinha muito pouco brinquedo, mas se brincava muito. Brincava-se na rua, a gente tinha muito contato com pessoas mais velhas, então você aprendia muitas coisas. Por exemplo: eu lembro que minha mãe trabalhava e que em determinado momento, que eu ficava com uma senhora, que ela costurava. Então eu ficava ali... Eu não me lembro dela falando assim, "Nair, faz isso!", "Corta isso!"; mas eu tenho uma habilidade para costurar, para criar, assim, para tecido, e eu tenho uma... que, eu acredito que, hoje, eu vejo, veio disso. Aí a outra, fazia não sei o que, você ia na casa dela, e você acaba tendo aquele contato ali, e... aprendi; então, cada uma tinha uma maneira, cada uma tinha um jeitinho, então tudo isso ia somando, então você tinha uma coisa de respeito, que eu acho que hoje.. Eu não sei de que forma que as pessoas entendem respeito hoje, mas eu fico pensando, assim: Será que...? "Ah, porque tudo precisa mudar, precisa mudar, precisa mudar..." Aí eu fico muito preocupada com isso, porque, precisa mudar, mas esse mudar, assim, eu confesso para você que eu não tenho visto esse resultado; pelo menos... Eu estive numa escola, esses dias, eu não sei se você já assistiu; você deve ter assistido, aquele filme "Ao Mestre, com Carinho" ...

Vale sublinhar que a formação educacional de Nair passava pelo aprendizado junto à convivência dos mais velhos da comunidade: "a gente tinha muito contato com pessoas mais velhas, então você aprendia muitas coisas”. Era no espaço público da rua o local onde as crianças socializavam as brincadeiras, sob a supervisão dos mais velhos: "Brincava-se na rua, a gente tinha muito contato com pessoas mais velhas, então você aprendia muitas coisas". Percebi que a formação e vivência junto às pessoas de mais idade ocorriam tanto no espaço público da rua quanto no espaço privado. O depoimento de Nair corrobora a ideia da importância das convivências intergeracionais no processo formativo dos indivíduos. Mais do que promover o respeito ao próximo, a convivência com os mais idosos 
possibilita o respeito ao conhecimento prático de pessoas simples, que não chegaram a obter diplomas acadêmicos.

Como observado em uma das narrativas, são muitas mulheres que além do cuidado com integrantes da família também "olham" os filhos e filhas de outras mulheres enquanto elas saem do espaço doméstico para o trabalho fora de casa. Trata-se de um trabalho comunitário que a partir de 2000 no Brasil adquire o sentido de participação social, conforme Bila Sorj (2016). A autora destaca que o Banco Mundial passa a defender a cultura e as redes sociais no fortalecimento de programas que incentivam laços comunitários:

Se até poucos anos atrás entendia-se por participação comunitária movimentos de protesto e de defesa de direitos sociais, mais recentemente, essa noção ganhou um novo significado que se refere à integração de moradores de bairros pobres em projetos que visam o desenvolvimento social de suas localidades. (SORJ, 2016, p. 111)

Sorj (2016, p. 111) complementa afirmando que embora a noção de "participação comunitária" pareça que exista um envolvimento de toda comunidade no "recrutamento para atuar nos programas sociais" o chamado refere-se especificamente às mulheres que têm inserção precária no mercado de trabalho e são mais atuantes nos movimentos sociais "por direitos nos bairros populares"

Guardadas as devidas proporções sobre a responsabilidade da participação comunitária nos cuidados de filhos e filhas, os depoimentos narrados revelam visões de mundo particulares, mas que têm em comum o fato de serem mulheres, mães, conselheiras e moradoras da periferia as responsáveis exclusivas no cuidado dos filhos e filhas. As conselheiras fazem questão de afirmar sua condição de mãe e de narrarem suas dificuldades, a mesma condição da maioria de mulheres moradoras das periferias das cidades brasileiras. A atividade de cuidado com filhos e filhas, realizada no espaço privado doméstico, obriga que essas mulheres se voltem para o lar durante o período em que a prole exige os cuidados essenciais, levando-as a renunciar ao tempo de atividades fora de casa. Abdicam do trabalho formal e com isso da independência financeira, da participação em atividades físicas, do cuidado de si, e de se lançarem fora de casa em outros espaços participativos. Entretanto, são muitas delas que mesmo com a dedicação em duas e três jornadas buscam atuação em espaços participativos na periferia.

A experiência de participação comunitária de Nair, quando menor de idade, através de "uma cultura que tem treze, quatorze anos e você tinha que trabalhar para ajudar em casa" foi de valorização do trabalho. O histórico profissional da conselheira, caracterizado 
pela inserção em ocupações administrativas de maior proximidade com o público e suas atuações profissionais no orfanato e no Hospital Sorocabano, no bairro da Lapa, contribuíram para uma reflexão em torno das condições sociais: "porque eu comecei refletindo algumas coisas, principalmente quanto à vida, quanto à beleza, quanto à condição social". No trabalho de atendimento ao público de baixa renda da população oriunda, principalmente, do município vizinho de Franco da Rocha, no Hospital Sorocabano, ela passa a refletir novos paradigmas e visões de mundo:

Minha questão de beleza também mudou, e isso eu acho que isso me influenciou muito para ver a vida de uma forma diferente. E aí você vai construindo um mundo onde você vê. Porque ali você vê a pessoa, quando ela não tem acesso à saúde, ela fica muito fragilizada. Então eu começava a ver o ser humano, assim de uma forma bem diferente.

Em outra experiência profissional marcante, ela narra a reação de um rapaz que não compreendia as decodificações de documentos. Mesmo tendo ouvido, anteriormente, a explicação de quais folhas devia ter assinado para receber o benefício do Instituto Nacional do Seguro Social (INSS), ele "amassou tudo e começou a jogar" os papéis logo após ter escrito em local errado. A explicação sobre o local de assinatura não foi corretamente entendida pelo interlocutor, já que a cor do documento, rosa ou verde, determinava o tipo de atendimento do serviço público. A percepção de Nair, diante da reação do rapaz a levou à compreensão da importância da educação e da comunicação no processo formativo das pessoas:

Eu lembro dessa cena até hoje, porque a limitação dele, de entendimento, hoje eu entendo que a pessoa vai ficando um pouco bruta, quando ela não consegue. Ela só tem aquela forma de se expressar. E eu ficava olhando aquilo, assim, e começava a fazer uma leitura. Então, eu sempre tive, eu acho que ali, a partir dali eu tive um olhar, assim, maior para a questão da vivência, do social. Porque parece que não, mas quando você pega uma pessoa, e você pega ela pelo braço e você fala, "Vem cá, eu vou te explicar onde que é: à direita, à esquerda". Você pega uma pessoa, assim, e transforma ela, um homem, uma senhora idosa e você carrega ele pela mão e você direciona ele, você se torna um pouco educador, naquela hora.

Novamente Nair chama atenção para a importância da vivência e do processo educativo de "pegar uma pessoa" e "transformá-la", assim, passa a ser "um pouco educador". Enquanto por um lado Nair trata da valorização da convivência como complementar ao processo educativo, ela também relata as consequências da ausência de convivência. Segundo a dona de casa, a falta de relação dos jovens com os mais velhos impacta o tratamento da juventude ao docente em sala de aula, trazendo consequências negativas ao aprendizado. 
Um fato notório é que, embora a responsabilização pelo cuidado dos filhos e filhas deva ser da família, incluindo a figura do pai, as mães são as únicas responsabilizadas pela criação dos filhos. A preocupação de Nair com a educação dos filhos, em fazê-los compreender que o significado do momento lúdico do ato de brincar não se restringia ao consumo. Em um dos trechos anteriores, Nair valoriza a vivência quando criança, junto aos mais velhos, e abaixo, ela repete a valorização desse modelo de criação que prioriza a vivência comunitária. Ainda é possível observar a referência que ela faz ao trabalho assalariado, ao mencionar não comprar brinquedos para os filhos:

É, porque, como eu falei para você, e hoje se tem tudo que eu não tinha, e as pessoas ainda falam que não tem nada! Então eu não sei. Então, o que eu ensinei... eu ensinei os meus filhos é que... você tem que ter uma coisa de criação, de vamos partir aí. Eu nunca trabalhei para comprar brinquedos para os meus filhos. Porque eu não entendia que brinquedo era uma coisa assim, que você comprava. Desculpa, assim, falar para você. Quando eu dei um videogame para os meus filhos, eles não gostaram. Tive que vender, porque eles achavam, que eles queriam brincar com as crianças no meio da rua. Não é errado. A gente está em um mundo aí, e o mundo está andando para frente, mas... Sei lá, eu vejo que as pessoas trabalham muito para ter tênis, para ter roupa e... Meu, sinceramente a vida é muito... Eu acho que é uma nova maneira de viver, você está entendendo?

O significado de educação dos/as filhos/as envolve ensinamentos de valores, além dos cuidados. Essa socialização tem o sentido de imprimir nos filhos e filhas o comportamento apropriado de enxergar o mundo. No trecho a seguir, Nair conta seu esforço em valorizar as brincadeiras das "crianças no meio da rua" em vez do incentivo ao consumo. Criar também é se preocupar com saúde bucal dos/as filhos/as. Em sua observação, associa positivamente o espaço público do "meio da rua":

Assim, eu sempre fui... Não que os meus filhos nunca tivessem, é... Por exemplo, eu vim de uma de uma condição em que eu tive muita dor de dente; eu nunca quis que os meus filhos tivessem dor de dente; é horrível, horrível. Você sabe que uma coisa que eu acho legal, dentro do trem, e eu falo que isso eu vi que o Brasil andou, porque eu falo assim, puxa, eu vejo esses meninos dentro do trem, vendendo as coisas, assim, sabe o que eu reparo? Que eles têm os dentes muito bonitos. Eles não têm dentes... Porque o Brasil conquistou. Com essa coisa da saúde, do flúor... Então eu fico muito feliz, porque a minha geração foi uma geração que usou ponte, que sofreu muito com dor de dente... você está entendendo?

Como responsável pela criação dos filhos, o entendimento de Nair é que eles/as não experimentem o sofrimento da dor de dente vivida por ela na juventude. Além disso, ela destaca o caráter educativo da criação dos filhos, a convivência com os mais velhos, segundo ela, necessária ao processo formativo das crianças: "Então eu fico pensando: "Será 
que não está faltando um pouco dessa vivência, do novo com o outro, com o mais velho?" Chama atenção na entrevista de Nair a ênfase e a repetição que ela faz da palavra vivência: foram oito vezes. Em todas as ocasiões empregadas na entrevista, o significado da palavra "vivência" estava relacionado ao aprendizado junto às pessoas, com idade mais avançada, experientes e com bagagem a contribuir.

Lilian também ressalta que após problema de saúde e ter se aposentado, com filhos ainda pequenos, conseguiu forças para se engajar no movimento de bairro de apoio ao CEU, em 2005. Ela foi a única entrevistada que participou da criação do CEU de forma mais intensa:

Eu aposentei e na época que meu filho foi para a escola aqui não tinha vaga para todo mundo, não tinha do CDHU, e as escolas não tinham onde suportar tanta criança. Aí me chamaram para ajudar que viria o CEU para cá.

Assim como as conselheiras Mercedes e Lilian, Mariana também passou a frequentar o espaço do CEU somente após se aposentar, porque o cuidado com o filho, marido e o restante dos afazeres de casa a impediam de frequentar o CEU. Moradora do bairro desde 1996, viu o CEU ser inaugurado em novembro de 2003, porém, somente em 2009, quando se aposentou, que começou a frequentá-lo. Atribuiu ao atraso em frequentar o espaço à dificuldade de conciliação das atividades no CEU com o trabalho na metalurgia: "Sempre tive um filho para cuidar, marido, casa para cuidar, então as coisas ficavam bem apertada para poder fazer".

De forma igual, Silva (2010) compreende o caráter pedagógico entre as mulheres bordadeiras de Ipatinga, "que acrescenta e contribui no processo de formação humana, na (re)significação de subjetividades e construção de novas sociabilidades, num processo que se manifesta no coletivo, porém só passível de ser assimilado e apreendido individual e subjetivamente". As mulheres do CEU compartilham em comum com as bordadeiras de Ipatinga a "caminhada pessoal e intransferível de cada mulher envolvida e implicada nesse grupo que mais que um coletivo torna-se uma fratria de mulheres”. (SILVA, 2010, p. 238)

A experiência participativa institucional de Nair esteve limitada a algumas ações voltadas para as pessoas e não órgãos: "nada muito pontual”. A conselheira alega não ter vivenciado nenhuma experiência participativa em algum outro "movimento", para além do relatado. Desconhece o entendimento de "movimento", já que do seu ponto de vista, a atuação em movimento está relacionada à ação. Mesmo assim, os relatos de Nair contêm elementos que mostram experiência de participação social que nenhuma outra conselheira mencionou. Em seu depoimento, que demonstra preocupação em reunir e organizar, 
previamente, as mulheres da comunidade, ela revela experiência participativa em espaços coletivos:

Eu era de um lugar, de um tempo onde se tinha comunidade de bairros e onde tinha aquela Associação de Moradores do Bairro. Então, eu até penso, assim, que toda pessoa, para passar pela política, ela tinha que passar por essas bases.

Desde o ano de 2000, Mercedes não trabalha formalmente fora de casa, dessa forma buscou conciliar os horários de cuidado dos filhos pequenos com o trabalho doméstico, de modo a estar com jornada livre para participar das atividades no CEU. Mesmo tendo se voltado para o espaço doméstico, com a saída do mercado de trabalho, desde 2000, a conselheira passa a participar do CEU, como uma forma de cuidado de sua saúde, em atividades de prática de esportes:

Eu trabalho em casa e desde 2000 eu não trabalho mais registrada. Daí eu trabalho em casa. Logo que surgiu o CEU, eu sempre participei da parte de esporte. Meu marido sempre trabalhou. Mas, com os filhos pequenos, daí eu tentei conciliar os horários. Porque eles nunca estudaram aqui, mas eu levava e buscava os filhos. É próximo, mas eu levava e buscava. Daí eu tentei conciliar. Comecei até hoje tem esse professor aqui, o professor Caio. Ele dá ginástica aqui e é um ótimo professor, todos eles. E com ele eu comecei a fazer...

Mercedes teve uma trajetória similar a outras mulheres conselheiras entrevistadas. Mãe de dois filhos, sendo que nenhum deles tinha estudado no CEU, sempre participou das atividades esportivas oferecidas pelo Centro Educacional. Mesmo alegando que não tenha sofrido influência externa para participar do Conselho Gestor, Mercedes conta que na juventude sempre gostou de política, junto com seus irmãos, já que seu pai e marido eram metalúrgicos. O gosto por política levou Mercedes a se engajar no Partido dos Trabalhadores (PT), na época que, segundo ela, o partido defendia os interesses da classe trabalhadora. Também declarou ter sido eleitora da ex-prefeita Marta Suplicy, que criou em sua gestão, no município de São Paulo, o projeto do CEU:

Nossa, eu era, eu era petista roxa. Eu era muito, assim, ativa mesmo, eu brigava mesmo, eu era muito, sabe? Porque eu acreditava, eu acreditei e ajudei, entendeu? Enquanto era um partido voltado para os trabalhadores. Então, e por meu pai ser metalúrgico, tanto que o meu marido sempre foi metalúrgico também, e ele também sempre foi petista. Então, quando era um partido, assim, voltado para as causas dos trabalhadores. E, eu sempre votei nos candidatos do PT e tudo mais. E continuei votando na Marta, mesmo agora quando ela mudou de partido e tudo que ela foi uma boa. Ela fez coisas boas, ela foi uma boa prefeita e tudo. Então eu vejo por aí. Hoje eu não sei, eu posso até pensar, repensar; mas eu votaria nela como prefeita, novamente, votei da última vez; os outros candidatos eu anulo tudo. 
A noção de participação que Mercedes confere está associada à ideia de hostilidade, luta e confusão, quando "brigava" na época de atuação partidária. Decepcionada com a atuação dos partidos, conta não estar "abraçando" nenhuma causa partidária, porque, segundo ela, a atuação político-partidário transformou-se em sinônimo de troca de favores por cargos. Ao longo de toda a entrevista, Mercedes se posiciona contrária à política de troca de favores presente nos cargos comissionados dos órgãos públicos, pois entende que a capacidade de ocupação em cargos políticos não passa, exclusivamente, pela atuação partidária institucional:

São pessoas sensacionais, mas eu não aceito, eu não concordo com esse negócio de vereadores, deputados poder colocar dois funcionários. Eu acho, eu bato na mesma tecla: nós somos todos iguais, todos têm direitos iguais, todos temos deveres iguais, todos pagam impostos iguais, então o que é isso? Por que que você tem direito a um emprego aqui dentro, sendo que meu filho poderia também ter, pela capacidade, pela inteligência, entendeu?

O depoimento de Mercedes é claro: ela associa o mecanismo de acesso a cargos eletivos à relação de compra e venda de votos e apoio político. Por entender que se trata de abuso de poder, seu julgamento sobre a participação política passa pela ótica da moralidade. O que justifica a sua aversão à adesão partidária:

É por isso que eu não quero esse negócio de partido, eu acho muito injusto, e outra: se a pessoa me fez um favor de me dar um emprego, me dar um emprego, um negócio meio... Não fica um negócio assim meio correto. Que é um negócio meio de compra e venda. Sabe? Eu voto na Marta, ela não tem que me dar nada, ela tem que cumprir o que ela ali. Ela se elegeu.

Se considerarmos os valores democráticos pelos quais os CEUs foram instituídos, teremos o paradoxo de uma instituição que defende o princípio participativo e de acessibilidade junto à comunidade, que tem um Conselho Gestor paritário, adotando forma autoritária em prol de interesses políticos locais.

Vale lembrar que as exigências e requisitos mínimos para a ocupação de cargo de gestão do CEU, fixado pelo Decreto $\mathrm{n}^{\circ}$ 57.478, de 28 de novembro de 2016, está a necessidade do/da gestor/a ser profissional da área da Educação efetivo da Rede Municipal de Ensino, há no mínimo 03 anos e integrante do quadro de magistério municipal. $\mathrm{O}$ processo de seleção do cargo de gestor/a do CEU passa pela indicação política, nomeado por ato do Executivo Municipal, conforme indicação do Secretário Municipal de Educação, segundo o Capítulo 1 do referido Decreto. Embora a gestão dos CEUs tenha como princípio, “a participação democrática, com a tomada de decisão coletiva com a 
participação direta da população nos processos eletivos e de avaliação", como prevê no artigo 32 do Decreto de 2016, os cargos de direção são de indicação política, submetidos às forças políticas de cada região e de acordo com o prefeito em exercício.

A crítica que Pacheco faz é justamente a intervenção do executivo na decisão de escolha do gestor do CEU, a partir de 2005, excluindo da deliberação a consulta popular: “acabaram por dificultar e até mesmo impedir a possibilidade de gestão democrática, embora o discurso oficial fosse absolutamente otimista com relação a isso." (PACHECO, 2009, p. 104). A autonomia e prática de gestão democrática, princípios originais dos Centros Educacionais Unificados, fica comprometida com as alterações do Regimento Padrão dos CEUs, principalmente no Regimento aprovado em 2006 (PACHECO, 2009).

No trecho a seguir, ao manifestar seu gosto pela participação, Mercedes compreende a participação como sinônimo de ajuda, e associa a algo positivo. Faz recomendação à participação popular como estratégia de ação que deve passar, necessariamente, pela transparência, de forma a evitar a compra de votos e a manipulação:

Sim, porque sempre gostei muito de participar, assim, de participação ativa assim, de ajudar, também, sabe? Porque eu acho assim, eu acho que tudo, não é nem por políticos ou coisas assim, mas eu acho que se o povo realmente quer, o povo consegue. E é assim, tem que ser transparente e você não pode ficar inventando coisas. É porque acaba nesse negócio de favores, e esse negócio de favores, sempre tem coisa que não presta. Então é por isso que a gente tem que ser muito correto e transparente. A gente não pode ficar nessa de favor e deixar as pessoas manipularem. Porque daí vira um negócio podre.

Perguntada sobre a possibilidade de vir a atuar na política profissional, Mercedes nega, categoricamente, sua participação, porém conta ter ensaiado a atuação em movimento de moradores, junto com a adesão de deputados e vereadores e da Igreja Católica Comunidade Nossa Senhora da Aurora:

E para se começar uma associação, registrada e tudo mais. E estava até tudo, já os documentos dando andamento em documentos e tudo mais. Eu estive em algumas reuniões dessas, que eu tive interesse em participar ativamente, porque, além aqui dos CEUs a gente tem muitos problemas, assim... Se você vê as fotos aqui daqui da região, é péssimo; a iluminação é péssima, a limpeza é péssima; segurança não tem. Então tem muitas coisas aqui; e, através de moradores bem antigos... Essa estação, essa estação, pessoas mais antigas que eu porque eu moro aqui há 28 anos, já. Então pessoas mais antigas que eu dizem que já estava registrada, documentada essa estação há, acho que 50 anos atrás. Ela é nova, ela tem... Bem depois do CEU que foi surgir a estação.

O objetivo do movimento de moradores era a transformação em associação para pautar reivindicações de melhorias da infraestrutura local, como iluminação, limpeza, 
segurança, melhorias na própria estação de trem, a reivindicação da criação de instituição financeira bancária e de creches. Entretanto, após algumas reuniões, a burocracia impediu a continuidade do movimento, como alega Mercedes.

A narrativa da conselheira ressalta a importância de melhorias na comunidade e seu caráter denunciativo acerca as péssimas condições da creche conveniada da Prefeitura em logradouro de sua residência:

Você precisa de ver a areazinha que eles ainda cobriram com um toldo transparente pras crianças poder tomar um sol. Eu não gostaria de ver minha neta nessa creche. É um sobrado, de uns quatro andares. Mas é muito úmido, é um negócio sinistro, sabe?

De acordo com seu ponto de vista, a função do movimento de moradores é atuar na criação de uma frente de resistência contra a compra e venda de interesses privados junto ao poder público. Aliás, ao longo de sua narrativa, a crítica à política está relacionada ao combate das relações espúrias de particulares na compra e venda de favores públicos. A denúncia de que a direção da creche está possivelmente sendo usada como "laranja" no negócio, jargão policial que significa o empréstimo do nome para ocultação de origem ou destinatário de dinheiro ilícito, refere-se à relação antiética e criminosa entre o públicoprivado:

Então, eu queria, assim, participar de uma associação, mas para essas coisas, para denunciar. Por que que a prefeitura tem que fazer essa aliança em lugares como esse? Que faça, mas para o bem das crianças, não para o bem do bolso de quem está locando o lugar. Porque falaram que é um horror o que eles pagam de aluguel. Ou, para uma diretora que está sendo usada. Que eu conheço muitas dessas creches, que eles pegam uma pessoa que é formada, que tem como um registro para ser diretora como laranja. Porque por trás disso tem as pessoas que são dona do prédio, da terra, para ganhar dinheiro em cima. E assim vai indo. Não sei se você está me entendendo.

Ao final da entrevista, quando Mercedes foi solicitada a completar algum comentário que julgasse ser necessário, que porventura não havia sido explicitado durante a conversa, ela associou a "participação" a um processo de aprendizagem constante, manifestando o desejo de ver os moradores participarem das atividades do CEU. Para ela, o espaço institucional do CEU poderia congregar o local para o aprendizado dessas práticas democráticas:

Então, mas é a gente aprende a cada dia. Eu vou aprendendo também, e tento, é. O que eu queria muito, sabe, que eu tinha contado, é com as pessoas, aqui, moradores, todos usuários participarem; porque tem gente muito boa, sabe? 
Paulo Freire sugere a necessidade de "democratizar o poder, reconhecer o direito de voz dos alunos, às professoras, diminuir o poder pessoal das diretoras, criar instâncias novas de poder com os Conselhos de Escola, deliberativos e não apenas consultivos". Ou seja, ao conceber a prática educativa como “uma dimensão necessária da prática social” se faz necessário a ampliação dos canais de participação da comunidade em uma democracia brasileira "em aprendizagem" (FREIRE, 1995, p. 38). Antes de fazer a crítica do significado de participação predominante na sociedade, que valoriza o imediatismo e a lamúria, Mercedes destaca o potencial participativo da comunidade:

É, que fazem atividades aqui e têm ideias legais; que ajudaria muito, ajudaria a cuidar. Porque tem muita gente que pegou a mania de só reclamar; é o que eu estou te falando, todo mundo gosta de tudo pronto.

Finalmente, critica os usuários/as do equipamento que renunciam à participação no espaço do CEU, mas almejam o imediatismo para as melhorias na comunidade:

Querem ter as coisas, querem ter coisas legais, querem usar e tudo mais, mas quer tudo pronto. Falei, gente, mas infelizmente, a gente, para ter tudo, tudo que a gente quer e tudo pronto, a gente tem que batalhar por isso. Não é assim!

Em outras palavras, a conselheira compreende que a melhora das condições sociais se mantém pela constante participação popular, entendimento predominante entre as demais entrevistadas: "Tem que batalhar, tem que construir, batalhar e outra: se hoje está bom, tem que participar, e tentar cuidar, para que continue bom."

Mesmo que as mulheres percebam a necessidade de atuação popular para a mudança do status quo, existe uma consciência do déficit participativo no espaço do CEU. Lilian tem essa compreensão e crê que o espaço deva congregar diferentes opiniões:

Eu acho que deveria participar mais, porque é mais cabeça pensando, cada um tem uma ideia diferente.

Após vivenciar as experiências de participação, tanto no mercado de trabalho quanto em sua inserção em luta por educação no bairro, antes da construção do CEU, Lilian nega qualquer possibilidade de atuar profissionalmente na política, associando negativamente o desempenho parlamentar, assim como Mercedes: "De jeito nenhum! Deus me livre!"

De todas as entrevistadas, Mariana foi a única que conviveu desde pequena no meio de reuniões políticas partidárias. O gosto pela participação foi herança de sua família de políticos, tanto pelo lado da família de sua mãe, quanto de seu pai, em Juazeiro, no interior da Bahia. O primo de seu pai foi eleito prefeito da cidade, em 1974. Como ela mesmo conta, 
assim que chegou do "Norte", em referência à migração da Bahia para a região sudeste do país, em 1975, começou a estudar, aos 16 anos:

Aí quando eu comecei a estudar eu vim do Norte eu só sabia fazer o nome, aí eu comecei a estudar.

Já, em São Paulo, no período em que trabalhou no setor da metalurgia, durante vinte anos, Mariana foi integrante da Cipa, que é um comitê dos trabalhadores no tratamento da prevenção de doenças e acidentes de trabalho. Seu gosto pela participação popular também a manteve ativa no movimento da Vila, nas décadas de 1980 e 1990, quando atuava como representante popular na reivindicação de iluminação, água, esgoto e linhas de ônibus:

É, agora acabou, não tem mais, mas representava para iluminação, para água, esgoto, linha de ônibus. Perdia muito tempo, muitas horas de serviço correndo atrás disso. No dia que veio a linha de ônibus aqui eu que subi lá em cima para representar as reuniões. Porque eu gosto mesmo.

No período eleitoral para o governo de São Paulo, Mariana trabalhou na campanha de reeleição do então governador Mario Covas, em Santos. Mesmo em 2018, quando atuava no Conselho Gestor do CEU, Mariana ainda mantinha participação em reuniões e contatos com vereadores e deputados.

Durante a eleição municipal de 2016, em São Paulo, após convite, passou a integrar a campanha do vereador Paulo Frange, do Partido Trabalhista Brasileiro (PTB), mesmo não sendo filiada ao partido. Frequentemente, quando possui alguma demanda, recorre ao seu contato do gabinete do vereador para fazer o agendamento prévio para a conversa, assim como também busca na Câmara Municipal de São Paulo o contato com outros vereadores. Na ocasião da entrevista, em 02 de maio de 2018, Mariana mencionou que estava para receber visita do vereador de São Paulo, do Partido Socialista Brasileiro (PSB), Eliseu Gabriel, cujo secretário de gabinete conta ser seu amigo:

Ele era antes aí saiu, agora chamaram ele de volta. O Fred. Ele passou a mensagem perguntando se eu recebia ele hoje, eu disse que recebia que era só ele marcar o dia.

Finalmente, Mariana declara seu sonho em prosseguir a carreira política, única manifestação observada entre as entrevistadas:

Olha, eu vou the falar uma coisa, se eu fosse mais jovem e tivesse mais um estudo assim, uma cultura, e eu não tenho, só fiz até o oitavo, pela metade ainda, se eu fosse mais jovem eu ia, eu ia tentar. Mas as minhas condições não ofereceram na época quando eu deveria fazer. 
Vemos neste último depoimento, que a carreira de atuação política profissional seria uma opção na vida de Mariana caso fosse mais jovem, e as oportunidades de estudos fossem uma realidade acessível.

Cumprindo primeiro mandato no Conselho, como representante da comunidade desde 2017, Renata executa mandato de conselheira no período de vigência do colegiado de 2016-2018 no CEU. Ela chegou ao Conselho a convite da amiga, Mercedes, outra conselheira, para participar em uma das reuniões. Utilizava o espaço do CEU para a prática de atividades físicas antes de chegar ao Conselho Gestor. Fica claro durante a entrevista o entendimento único sobre o espaço do Conselho Gestor e o espaço do CEU. No trecho é possível perceber a relação intrínseca do espaço do CEU e do Conselho Gestor, conferida por Renata. Ou seja, os espaços do Conselho e do CEU se misturam, e isso pode ser observado quando a entrevistada diz pertencer à comunidade do CEU e frequentar as reuniões do Conselho Gestor:

Eu sempre fui da comunidade. Utilizo as atividades do CEU, há três anos. Eu faço ginástica, funcional, caminhada. As atividades que fornecem para a gente. Aí eu fui convidada pela Mercedes a ir em uma das reuniões, que eu já era conselheira do gestor há muitos anos já, e fui para conhecer. Acabei conhecendo, gostei e não faltei mais a nenhuma reunião.

Renata nunca participou de movimento social, mas disse ter o desejo de "brigar por causas" que acredita serem necessárias. Então, a participação no Conselho Gestor representa a materialização desse desejo, que outrora não havia sido realizado por falta de oportunidade: "Então, quando eu comecei a conhecer, quando eu comecei a me envolver, eu comecei a participar das festas da escola, das coisas externas". No trecho abaixo, a dona de casa observa o aumento da divulgação do Conselho Gestor na comunidade, embora lembre que o colegiado não tenha atingido o patamar ideal de participação:

Essa gestora agora nossa, ela tem muito contato com a comunidade também, então, ela fez também que os coordenadores fossem aos grupos de ginástica, que os coordenadores fossem aos grupos de caminhada e convidassem o pessoal que frequenta o CEU a participar no Conselho. Então eu vejo que esse ano houve mais divulgações, mas ainda não é o patamar que precisa.

A dicotomia casa versus rua, espaço privado versus espaço público abordada pelo antropólogo Roberto DaMatta (1997) vai adquirindo nuances. Para a pesquisa interessa a compreensão de como a participação das mulheres no espaço do CEU influencia a sua vida doméstica. Partindo do entendimento de DaMatta, é nos festivais ocorridos no CEU que “as rotinas diárias” passam “a ser modificadas”. (DAMATTA, 1997, p. 26) 
O mundo diário pode marcar a mulher como o centro de todas as rotinas familiares, mas os ritos políticos do poder ressaltam apenas os homens; a vida diária centra a vida da casa nos adultos, mas num cerimonial como o do Natal as crianças adquirem uma importância extraordinária. (DAMATTA, 1997, p. 26)

Por meio das esferas da "casa" e da "rua", o antropólogo relaciona o sistema ritual brasileiro, entendendo o sistema ritual como complementares ao sistema social. É na junção da casa com a rua, ou seja, nos rituais de celebração que se "pode tentar refazer sua unidade" (DAMATTA, 1997, p. 44). Para o estudo, interessa a compreensão do significado da "casa", da "rua" e da celebração representada pelas festividades do CEU, úteis na análise dos conflitos vivenciados cotidianamente no CEU que, muitas vezes, são conflitos antecipados e debatidos no Conselho Gestor, e externalizados nos eventos do Centro Educacional. Ainda conforme DaMatta "as rotinas diárias preservam o tempo na sua duração 'normal', ao passo que nas festas o tempo pode ser acelerado ou vivido como tal". (DAMATTA, 1997 p. 28)

São, portanto, várias as formas de participação das mulheres. Entre as tarefas do lar, de cuidado com filhos, casa e esposo, elas relataram transitar em espaços participativos antes de chegarem ao Conselho Gestor no CEU. A experiência de participação de um caráter profissional predominou nos relatos de Nair, Lilian e Mariana.

Nair também questiona o movimento de casa-rua e a necessidade das pessoas em se deslocarem para a rua. Interessante para se pensar sobre o dualismo espaço público e espaço privado na vida da dona de casa, e da importância do momento de sair para a rua: “Às vezes eu fico pensando assim, sabe, Cristiane, fico olhando como as pessoas têm ido para a rua. Por que que elas preferem a rua, a não ser a casa? É uma coisa a se pensar."

Foi no espaço fora de casa que elas vivenciaram experiências com outras pessoas, para além do espaço doméstico, que moldaram a visão de mundo e de participação na esfera pública. O compromisso educativo de Nair, para além do profissional, quando lembra do atendimento às pessoas sem escolaridade durante sua experiência profissional, assim como a prévia experiência de atuação no movimento local por educação antes da chegada do CEU, faz parte da história de Lilian. Cada espaço ocupado tem seu significado e importância no curso da vida de mulheres periféricas que sempre sobrepuseram o espaço privado doméstico em detrimento do público. O CEU representa o espaço público institucionalizado, que reúne e possibilita a saída das mulheres periféricas do espaço do privado, um espaço que é caracterizado pelo cuidado ao outro e que sobra pouco tempo de cuidado para si mesma. É no CEU que as mulheres acessam à rua, a saída do lar e o espaço 
público no cuidado de si, por meio das atividades físicas, e não mais para o cuidado exclusivo dos filhos e cônjuges, que outrora se dedicavam no espaço privado do lar.

\subsection{A RUA É O CÉU, MAS É MINHA CASA TAMBÉM: CHEGADA AO CONSELHO GESTOR}

Nos depoimentos em suas múltiplas facetas de mães, avós, filhas, esposas, donas de casa, aposentadas e trabalhadoras - percebi que a aproximação ao espaço do CEU ocorreu em algum momento de suas vidas, quando foi possível a elas usufruírem de tempo livre, geralmente, quando se aposentaram. À medida que as trabalhadoras assalariadas deixaram de trabalhar fora de casa, passaram a preencher o tempo livre com novas atividades, relações de amizades e espaços sociais. Assim, elas se colocaram de um outro jeito na vida e sentem-se bem.

A maioria das conselheiras chega ao Centro Educacional Unificado após um longo período de trabalho fora de casa, sendo esse trabalho formal ou não. Paralelamente, todas as conselheiras também são encarregadas das tarefas domésticas dentro de casa, no cuidado do lar, dos filhos/as, marido e até mesmo de outros familiares, como netos/as e pais idosos.

Em 2009, já aposentada, Mariana chegou ao CEU porque sempre nutriu vontade de visitá-lo, mas, devido ao exercício de atividade remunerada fora de casa e ao acúmulo de afazeres domésticos, cuidados com filho e marido, nunca encontrou tempo de se aproximar do Centro Educacional. A chegada de Mariana ao Conselho Gestor seu deu por meio de abordagem de uma participante do Conselho enquanto ela fazia atividade física no equipamento no período da noite. Como era dia de reunião do Conselho, Mariana foi convidada a participar com a promessa de que a reunião seria breve e estaria prestes a começar. Naquela noite, Mariana decidiu aguardar o início e participar da reunião. Logo em seguida, candidatou-se, foi eleita para o Conselho e, até em 2018, na ocasião da entrevista, era a representante da comunidade:

Em 2009. Aí eu ganhei a eleição, e continuei no Conselho. Eu não me arrependo não. Tem vezes que tem umas brigas meio feias, mas passou dali continua.

Mariana foi a primeira entrevistada, e sua relação estabelecida com o CEU foi de um espaço com característica familiar, associado à sua casa, onde pode realizar as atividades físicas, conversar e debater problemas da comunidade:

Então aqui no CEU, pelo que eu passei aqui, acho que era muito a casa minha. Aqui eu tenho as minhas atividades físicas, os debates das coisas errada e das coisas certa, tudo por aqui. Se tiver alguma coisa que não 
está do meu acordo eu chego para conversar, procuro alguém para o debater o problema, quando eu vejo assim que tem algumas coisas que a gente tem que colocar, para o conhecimento ir para frente. Que as coisas não é para dizer que você coloca lá e vai andar, você tem que movimentar ela para ela andar, você tem que correr atrás para ver as coisas, tem que ter diálogo com as pessoas. Estou sempre convidando as pessoas para participar das coisas, tanto das atividades quanto do Conselho.

Para Caldeira, existe uma peculiaridade entre o cotidiano dos bairros centrais e das vilas. A antropóloga, ao descrever o Jardim das Camélias, em São Miguel Paulista, periferia de São Paulo, menciona o sossego da localidade, onde as mães não temem que seus filhos e filhas brinquem nas ruas. Descreve a vila e suas ruas sob a perspectiva do "quase doméstico", onde o bairro está para o espaço privado e íntimo, assim como o mundo público está associado ao restante da cidade. Conforme Caldeira, "se no trabalho e no espaço público do resto da cidade os indivíduos estão isolados, no bairro em que moram estão referenciados". (CALDEIRA, 1984, p. 120) E sob essa mesma perspectiva, pude perceber o porquê que as conselheiras se sentem em casa quando estão no CEU, sobretudo pela proximidade de moradia das conselheiras com o CEU. Caldeira faz a descrição da rua, a seguir:

A rua é quase que um espaço doméstico e pode-se, por exemplo, numa tarde de sol, colocar algumas cadeiras na frente do terreno e ficar conversando ou fazendo algum pequeno trabalho para escapar ao calor de dentro de casa. (CALDEIRA, 1984, p. 119)

Quando Mariana descreve o CEU como um espaço onde se discutem "coisas erradas" e "coisas certas", ela mostra que o espaço educacional é aberto à pluralidade de ideias, independentemente se estiver em acordo ou desacordo de sua opinião. É como em sua casa, sente-se à vontade para emitir opinião, concordar ou discordar de algum posicionamento. Interessante perceber o destaque que ela confere ao papel do diálogo e sua importância para a resolução de conflitos, como no trecho: "quando eu vejo assim que têm algumas coisas que a gente tem que colocar, para o conhecimento ir para frente.” E finaliza o trecho, mencionando que se sente confortável em estimular as pessoas para participarem do Conselho ou de outras atividades disponibilizadas no CEU: "Estou sempre convidando as pessoas para participar das coisas, tanto das atividades quanto do Conselho."

A segunda entrevistada, a aposentada de 61 anos e mãe de três filhos, Lilian, chegou ao Conselho Gestor por meio da luta e reivindicação por educação ao seu filho mais novo. Ainda antes da inauguração do CEU, Lilian relata seu esforço para que o CEU se instalasse no atual espaço, tendo em vista a baixa oferta de estabelecimentos educacionais e a alta 
demanda de estudantes da região. A sua preocupação com a distância entre a casa e a escola levou em conta seu problema de saúde:

Até 2018, Lilian tem garantido sua participação no Conselho Gestor nos processos seletivos no CEU, e diz encontrar dificuldades em se afastar do colegiado. Entretanto, nem sempre a conselheira esteve habituada em participar do fórum, já que seu principal objetivo, inicialmente, era a obtenção de uma boa escola para o filho estudar:

Olha, no começo porque eu queria meu filho na escola. Aí depois a gente vem porque, eu já me acostumei, tantos anos seguidos aqui, eu acho que eu não consigo.

No trecho a seguir, é possível perceber que a motivação de Lilian em continuar a frequentar o colegiado se deve ao gosto em dialogar e em se manter atualizada sobre o que ocorre na comunidade:

Esse ano eu falei assim, 'não vou, não vou não...' mas no último dia fiz a inscrição e consegui ser eleita ainda mais porque eu gosto de estar por dentro das coisas, porque é ruim você ver alguma coisa e não poder falar. $\mathrm{Eu}$ gosto de falar o que eu acho, eu gosto de expor.

Efetivamente, a entrada de Lilian no Conselho ocorreu pelos contatos pessoais que, paulatinamente, foi estabelecendo junto aos funcionários do CEU. Afirma que nunca encontrou obstáculos à sua participação inicial no CEU. À medida em que Lilian ia se "enturmando", foi conhecendo as pessoas e adquirindo conhecimento sobre o funcionamento do Conselho, conforme sua narrativa abaixo:

Como eu estava sempre muito aqui, eu sempre conheci o pessoal, gestores, que vieram, e sempre me dei muito bem com eles, aí tinha a imersão no Conselho, no começo eu não sabia direito como funcionava. Aí eu fui me integrando, fui sabendo assim, fui me enturmando com o pessoal. Ganhei a eleição assim disparada, fiquei até de boca aberta.

A inauguração do CEU não garantiu a matrícula de seu fillho no equipamento, mas também não manteve Lilian distante dos espaços de participação e de se relacionar com as pessoas. Mesmo sem o vínculo do filho ao Centro Educacional, ela passa a frequentar o espaço e a conhecer as pessoas. Por intermédio das redes de contato estabelecidas com funcionários, gestores e usuários, Lilian foi eleita ao Conselho Gestor com um número grande de votos. Em um de seus relatos, conta a perplexidade com que soube do resultado das eleições ao Conselho.

Lilian faz o resgate da memória ao revelar seu pertencimento à comunidade do Centro Educacional por meio das atividades físicas que realiza, cuja expressiva melhora do seu quadro clínico de esclerose múltipla foi por ela percebida. Ela também observa 
conhecimento sobre o projeto do Centro Educacional Unificado, inaugurado pela exprefeita Marta Suplicy, assim como destaca:

Mesmo assim, eu não deixei isso aqui, eu sempre fiz parte daqui assim, eu sempre procurei estar por dentro do que acontece aqui dentro. Aqui desde o comecinho assim, a padaria funcionava, quando a Marta veio inaugurar, foi feito dela, quando a Marta veio inaugurar a gente fez bolo, porque essa padaria eram cursos de qualificação para o pessoal aprender a trabalhar e a procurar serviço. Na época a gente fez bolo, a gente usou muito essa cozinha aqui, depois desativou. E agora, entrou o outro pessoal aí. Mas assim, eu sempre procurei estar por dentro, fiz atividade física aqui, melhorei bastante depois que eu comecei a frequentar aqui o CEU, fiz alongamento, fiz hidro, tudo que ele oferece aqui para gente eu faço.

Mercedes foi a quarta conselheira entrevistada. A artesã de 53 anos conta que desde a inauguração do CEU sempre participou das atividades esportivas no equipamento. Foi durante o período que utilizava o equipamento municipal, somente como usuária das atividades esportivas, que Mercedes passou a se interessar em buscar informações, no próprio CEU, sobre o paradeiro e o/os motivo/os de afastamento de algum funcionário/a terceirizado/a, tanto da segurança como do serviço de limpeza:

A gente vai pegando uma convivência no dia a dia, aí acaba. Não que sejamos amigos, mas é uma coisa, por eu morar aqui em frente, então eu sinto o CEU aqui como se fosse o quintal da minha casa, porque os momentos, assim, que eu venho fazer atividade física são os momentos só meus.

Percebendo que Mercedes se importava tanto pelos/as funcionários/as de sua convivência diária, além de estar sempre "alerta a tudo" o que ocorria no equipamento, e participar de todas as atividades, o professor de ginástica lhe convidou ao Conselho Gestor:

“Mas, professor, como que é isso?” Daí ele falou, "Não, tudo é colocado, tudo que acontece aqui no CEU é colocado em reunião, o que você ver de errado, você pode colocar. Eles vão colocar, nas primeiras reuniões vai ter o calendário do ano inteiro, o que você discordar, o sistema de vagas e tudo mais você pode discordar. Você pode. Você vê que está precisando de professores para tal área, você pode falar, e tudo. Problemas de segurança, problemas de acesso e tudo mais."

Diante da necessidade de quebra da rotina e isolamento doméstico, a participação serve como um escape e alívio ao estresse de casa, conforme observado por Caldeira:

A participação nos permite quebrar a monotonia e a amorfia do tempo, que de outra forma seria preenchido apenas com as tarefas domésticas. Eventos e reuniões estabelecem marcos na rotina diária, ocupam parte de algo que parece excessivo e lhe dão sentido em um momento que, de outra maneira, é percebido como disponível para servir aos outros e ao que é inevitável, em suma um tempo vazio O período das reuniões é um tempo 
que é claramente resgatado para si mesmo. (CALDEIRA, 1987, p. 92) (Tradução nossa)

Assim como Mercedes, Nair, de 55 anos, também chegou ao Conselho Gestor a convite de funcionários quando circulava pelos corredores do prédio participando de grupo cultural do CEU. Todas as entrevistadas chegaram ao Conselho Gestor por meio da circulação em outros espaços e serviços oferecidos no Centro Educacional, seja na área artística quanto esportiva. Em 2010, Nair começou a ter maior contato com a Comunidade do CEU, quando passou a ter mais tempo livre em função de ter deixado de trabalhar fora de casa. Combinando sua vontade de colaborar com as demandas da comunidade com a disposição do tempo livre, decide ingressar no colegiado, embora tenha afirmado nunca ter assumido, de fato, o cargo de conselheira, mesmo que, ao fim e ao cabo, desempenhe exatamente a mesma tarefa e possua o mesmo status de representante da comunidade:

Aí eu falei, 'Ah, quer saber de uma coisa? Acho que agora eu vou efetivamente. Eu já fazia parte de um grupo cultural aqui no CEU, mas eu vou efetivamente participar aqui da comunidade, tentar está mais a par do que está acontecendo. Aí eu entendi assim: vou pegar dois dias da minha semana e vou trabalhar aqui, junto com a comunidade, o mínimo que eu posso fazer. Assim, pensando em ajudar. E aí foi que eu falei, que o caminho, acho, que deve ser o CEU. Conversando, assim falei "vamos lá", vou participar do Conselho Gestor e vamos ver o que que eu posso ajudar.

Em seu discurso delineiam-se alguns objetivos que a motivaram a participar do colegiado, associado ao trabalho e a ajuda à comunidade nas seguintes passagens: "e vou trabalhar aqui" e "que eu posso ajudar". A estratégia de Nair foi reservar dois dias de sua semana para se dedicar ao "trabalho" de ajuda à comunidade junto ao fórum comunitário. O compromisso de trabalhar nos dois dias reservados propiciaria à conselheira aproximação à comunidade, mantendo-se informada sobre os temas próprios do CEU quanto da localidade em que vive. Para Nair, a atuação no Conselho representa exercer um papel ativo no interior da comunidade:

Entendo que eu vivo numa sociedade, então, isso faz com que você tenha deveres, e você também entenda que você pode usufruir desse convívio. Então, eu entendo que participar do Conselho Gestor é você se entender parte dessa comunidade, mas se entender como parte atuante.

Antes de chegar ao colegiado, a representante da comunidade e última entrevistada Renata utilizava o serviço do CEU como usuária das atividades físicas disponibilizadas no equipamento: 
Eu sempre fui da comunidade. Utilizo as atividades do CEU, há três anos. Eu faço ginástica, funcional, caminhada. As atividades que fornecem para a gente.

A partir de sua experiência de visita a uma das reuniões, Renata contou ter gostado e se comprometido com os encontros:

Aí eu fui convidada pela Mercedes a ir em uma das reuniões, que eu já era conselheira do gestor há muitos anos já, e fui para conhecer. Acabei conhecendo, gostei e não faltei mais a nenhuma reunião.

\subsubsection{Resolvi entrar no CEU para não ficar parada}

A maneira como se opera a vida das moradoras diz muito sobre a localidade em que residem. A dupla e tripla jornadas de trabalho doméstico, do trabalho fora de casa, do tempo gasto no transporte diariamente no percurso casa-trabalho impedem de participação em espaços públicos. À medida que deixam de trabalhar fora de casa, as mulheres se voltam a espaços de socialização participativos, representado pelo Centro Educacional Unificado, principalmente em uma região distante da região central que concentra a maior parte dos equipamentos públicos de esporte, cultura e educativos.

Mercedes, que concilia o trabalho doméstico com o exercício de atividade remunerada, eventualmente, em casa, contou-me que frequenta o CEU como um tratamento à saúde, também para a diminuição de sua ansiedade: "Uma das maneiras de eu diminuir o cigarro é estando aqui no CEU”. A importância simbólica do CEU é notadamente percebida nas entrevistas. Além do CEU estar situado na proximidade de sua residência, ele também revela ser um mecanismo de transformação da autoestima das usuárias, tanto no cuidado da saúde física quanto para o psicológico das mulheres, que estão voltadas para o trabalho pesado doméstico, muitas vezes de forma solitária. Mercedes fala da problemática de ficar em casa:

Eu falei, eu penso comigo: se eu fico em casa, porque eu já percebi que eu fumo muito por conta de ficar sozinha. Então é uma coisa automática.

O CEU representa para Mercedes um espaço de alívio diante das obrigações diárias domésticas, do enclausuramento doméstico, que gera ansiedade e outras doenças: "Daí, eu comecei a perceber que se eu ficasse em casa muito, assim, voltada para o serviço, para as coisas de casa e eu ia mais é fumar e fumar e fumar e ficar ali me acabando".

Antes de chegar ao Conselho Gestor, Mariana trabalhava fora de casa, e assim que se aposentou na indústria metalúrgica, decidiu frequentar o Centro Educacional. Na ocasião 
da entrevista, Mariana, com 61 anos, relatou as diversas formas de participação e de atuação no CEU:

Antes de entrar no Conselho Gestor eu trabalhava em empresa, eu trabalhava fora, aí quando eu me aposentei eu resolvi vir para o CEU. Para não ficar em casa parada.

Durante esses anos em que participa das atividades no Centro Educacional, com o intuito de não ficar em casa e se manter ativa, Mariana realiza atividades físicas, participa do Conselho Gestor, do Conselho da melhor idade e das atividades culturais. Conta que a atividade no Conselho exige o diálogo e debate sobre os temas da comunidade, além de também fazer o convite para que outras pessoas possam conhecer e participar do espaço.

Aqui eu tenho as minhas atividades físicas, os debates das coisas errada e das coisas certa, tudo por aqui. Se tiver alguma coisa que não está do meu acordo eu chego para conversar, procuro alguém para debater o problema.

O espaço do CEU representa o local onde é possível o cuidado físico, a sociabilidade e o diálogo com outras pessoas. Após perderem esses espaços e contatos com outras pessoas, quando param de trabalhar, as mulheres buscam o espaço educacional como um local que oferta oportunidades que outrora, quando inseridas no mercado de trabalho, não tinham tempo de usufruir.

Embora o meu objeto de pesquisa seja no espaço do Conselho Gestor e não o CEU, na sua totalidade, é impossível dissociá-los na percepção das mulheres conselheiras. As fronteiras são praticamente nulas entre o espaço do CEU, que congrega atividades educacionais, culturais e esportivas, com espaço do Conselho Gestor, que se reúne mensalmente no próprio Centro Educacional. Durante as entrevistas, pude perceber que, quando indagado sobre o espaço do Conselho Gestor, as mulheres conselheiras tendem, majoritariamente, a associá-lo com o espaço do CEU, e quando se referem ao CEU, as mulheres também compreendem o Conselho Gestor. Tanto no espaço do CEU quanto no do Conselho Gestor, onde opera a interação de discurso entre as participantes, elas concordam ou discordam, complementam ou simplesmente constroem a interação. Quando a Mariana diz, no trecho anterior, que no CEU é possível fazer as atividades físicas e debater coisas certas e erradas, ela nos mostra que o equipamento, ao reunir atividades educacionais, esportivas e culturais, também opera como um espaço promotor de interações dialógicas, cuja Conselho Gestor é somente um dos espaços existentes, já que ela menciona o Conselho da melhor idade, além das outras atividades que também são ofertadas pelo equipamento público, como das educacionais, esportivas e culturais. 
Quando eu vejo assim que tem algumas coisas que a gente tem que colocar, para o conhecimento ir para frente, que as coisas não é para dizer que você coloca lá e vai andar, você tem que movimentar ela para ela andar, você tem que correr atrás para ver as coisa, tem que ter diálogo com as pessoas.

Como espaço educacional, o CEU cumpre sua função educativa ao promover a interação, o movimento das ideias, reflexões, ou seja, opera a construção de discurso que se complementa e se constrói na interação. Conforme artigo $7^{\circ}$, do capítulo II, do Decreto $\mathrm{n}^{\mathrm{o}}$ 57.478/2016, um dos objetivos dos CEUs é a "ser um polo de experiências educacionais democráticas, emancipatórias e inovadoras”. Teise Garcia e Bianca Correa (2009), ao tratarem da qualidade da educação, compreendem que o projeto pedagógico é atividade crucial para o desencadeamento do trabalho coletivo na escola. Para isso, percebem a necessidade de que o projeto pedagógico esteja "articulado localmente e baseado nos princípios da autonomia, do trabalho coletivo e da gestão democrática" de forma que represente um "meio fecundo para produzir" a qualidade educacional. (GARCIA; CORREA, 2009, p. 233)

A conselheira Mariana destaca a centralidade do diálogo nas relações pessoais estabelecidas no CEU e a necessidade da troca com as outras pessoas e a valorização do coletivo, em detrimento do individual, sobretudo quando menciona que "está sempre vendo as coisas" não somente do ponto de vista de seu interesse, mas das outras pessoas, conforme abaixo. O convite à participação, tanto das atividades no CEU quanto da própria participação nas reuniões do Conselho Gestor corrobora a prevalência de seu envolvimento junto à comunidade educacional, esportiva e cultural do CEU.

Estou sempre convidando as pessoas para participar das coisas, tanto das atividades quanto do Conselho. Tem gente que ignora, mas não tenho tempo. Acontece esse tipo de coisa, e isso é você que não tem o que fazer. Eu tenho o que fazer. Eu procuro sempre estar vendo as coisas, não só por mim como pelos outros também. Estou sempre convidando as pessoas, "vamos na reunião", "vamos participar do Conselho da melhor idade", "vamos participar das atividades". Às vezes eu consigo trazer alguém para cá, mas que é difícil é. Nem todo mundo pensa certo. Acha mais fácil criticar pelas costas do que participar para contar a verdade. Saber que realmente tem muito para fazer.

No decorrer da entrevista, foi possível perceber a recorrência na fala de Mariana sobre a necessidade de "estar a par das coisas" por meio do "diálogo". O espaço do CEU, de acordo com a percepção da conselheira, é o local que possibilita o aprendizado e a troca de conhecimento entre os pares. Quando Mariana passa a frequentar as atividades do CEU para se manter ativa, ela inclui o diálogo como uma interação relevante, dentre outras, para 
"não ficar parada". Para Mariana, "ficar parada" significa não se comunicar, não aprender e não estabelecer contato com outras pessoas. Então, além de frequentar o CEU e participar das atividades culturais, educacionais e desportivas, que também fazem parte da ideia de se manter ativa, Mariana chama atenção para a importância do diálogo e da comunicação, relevantes no espaço do Conselho Gestor:

A coisa melhor que tem é você ter um diálogo, eu no meu caso, que tenho pouca cultura, com gente acima da gente, que tem um conhecimento, um diálogo diferente que você aprende também. A gente passa e aprende. Porque se eu começar a viver com pessoas piores do que eu, a tendência é ficar pior.

E assim como Mariana, Lilian também considera importante a participação no CEU para manter-se atualizada. Na passagem abaixo é interessante notar a noção de pertencimento de Lilian ao CEU. O fato de ter sempre participado das atividades no equipamento, desde a inauguração, a lembrança de ter ocupado a presidência do Conselho durante quatro anos:

Nossa, eu não lembro a data, mas estou aqui desde o começo, sempre fiz parte, já fui presidente acho que quatro anos do Conselho, porque a gente tem que se inteirar do que está acontecendo, por que isso aqui é da gente? Não pode virar as costas?

Nesse depoimento de Lilian, as narrativas sobre o CEU e o Conselho Gestor se misturam e se confundem, novamente.

Olha, no começo porque eu queria meu filho na escola. Aí depois a gente vem porque, eu já me acostumei né, tantos anos seguidos aqui, eu acho que eu não consigo. Esse ano eu falei assim, "não vou, não vou não..." mas no último dia fiz a inscrição e consegui ser eleita ainda, mas porque eu gosto de estar por dentro das coisas né, porque é ruim você ver alguma coisa e não poder falar. Eu gosto de falar o que eu acho, eu gosto de expor.

É importante lembrar que os relatos das mulheres não se limitam a justificar sua presença no CEU ou no Conselho Gestor a uma busca pessoal, de cuidado para com a saúde, por exemplo. Mais do que isso, algumas das entrevistadas buscam a melhora da condição educacional dos filhos e netos, ou seja, novamente elas se voltam para a função de cuidadoras dos outros e não de si. Lilian repete em diversas ocasiões que buscou "saber o que está acontecendo" no ambiente escolar do filho:

Eu não sei. Eu acho que a motivação maior que você tem é seus filhos estar lá, você tem que saber o que está acontecendo lá, eu acho, não sei se estou falando bobagem. Eu tenho que saber o que está acontecendo no ambiente que o meu filho está. Eu acho que falta interesse mesmo. 
A trajetória de Nair no CEU começa com participação em grupo cultural e sua posterior decisão em se dedicar também ao Conselho Gestor em 2010. Por se entender parte da comunidade, ela decide colaborar, reservando dois dias na semana para se dedicar ao Conselho Gestor:

Eu me propus, na minha agenda, a tirar um, dois dias da semana pra estar aqui, então, eu até comuniquei, falei com meu esposo, depois com meus filhos: "Olha, a partir de tais dias eu vou estar aí no CEU, vou estar vendo o que eu posso fazer, ajudando, participando. Vendo o que que pode ser feito. E aí eu me propus nesses dias, assim, eu vinha, e tentava estar a par do que estava acontecendo. Então esse era o intuito.

O CEU foi percebido por Nair como um espaço que pudesse se manter atualizada, quando deixasse de trabalhar fora de casa, já que deixaria de frequentar o espaço público. Outro critério utilizado na escolha do Centro Educacional foi a possibilidade de colaboração como forma de participação. Esse caráter colaborativo sublinhado por Nair pode ser compreendido na passagem abaixo:

Mas não no sentido em que eu posso fazer mais pelos outros, pelo outro, do que o outro por mim. Eu acho que é uma troca. Todo ser humano, ele se faz para mim... o ser humano, ele se faz dessa forma. Então, desde que eu tive filho, assim, eu entendi isso, então eu não entendia...

Renata mudou-se para o bairro no início da década de 1990, ou seja, ainda antes da inauguração do CEU, que ocorreu somente em 2003. Ela conta que frequentava os serviços do Centro Educacional, mas passou a utilizar com regularidade o CEU a partir de 2015, como aluna das atividades esportivas:

Eu sempre fui da comunidade. Utilizo as atividades do CEU há três anos. Eu faço ginástica, funcional, caminhada. As atividades que fornecem para a gente.

Notei que foi por intermédio das aulas da área desportiva do CEU que Renata passou a frequentar, em 2015, com assiduidade, o Centro Educacional, mesmo residindo no bairro desde o início dos anos de 1990.

\subsubsection{Uma pessoa de trinta anos, ela tem que estar correndo atrás da vida}

Não é sem justificativa que as mulheres conselheiras do CEU em sua maioria são aposentadas e possuem idade mais elevada. Para que possam estar presentes nas reuniões do Conselho Gestor e nas atividades do CEU, é necessário que disponham de tempo livre em horários de expediente de trabalho, privilégio que poucas mulheres em idade ativa desfrutam, ainda mais moradora das periferias das grandes cidades. 
Embora as reuniões do Conselho Gestor ocorram mensalmente, os encontros se alternam entre os períodos da manhã e da tarde. As reuniões têm duração de aproximadamente de 2 horas, portanto, a exigência de pré-requisito para a participação é a disposição de tempo. Na fala abaixo, de Nair, é possível perceber seu questionamento em torno da necessidade de aproximar diversos públicos etários no CEU, com destaque para o público das mulheres jovens. Justamente porque as mulheres jovens se encontram em um período da vida ativa, de inserção no mercado de trabalho, automaticamente tendem a se ausentar do espaço participativo no CEU. Percebi que a idade se torna um critério relevante que funciona como seleção para a participação no CEU, e especialmente no Conselho Gestor:

A comunidade vai poder participar, tal dia, tal dia, espera aí, mas não dá; por exemplo: uma pessoa de trinta anos, ela tem que estar correndo atrás da vida. Se ela está aqui dentro, tudo bem; mas e se ela não está?

Portanto, predominam entre as participantes mulheres de elevada faixa etária, muitas delas aposentadas, donas de casa ou até aquelas que trabalharam fora de casa, em um determinado momento de sua vida, mas que não chegaram a se aposentar.

Das cinco conselheiras entrevistadas, duas declararam ser aposentadas. Mariana e Lilian, além de possuírem em comum a condição de aposentadas, ambas têm mais de 60 anos de idade, e relataram ter trabalhado longo tempo em uma única empresa de carteira assinada. Enquanto Mariana trabalhou na indústria metalúrgica por 20 anos, antes de chegar ao Conselho Gestor, Lilian disse ter trabalhado e ganhado muito dinheiro antes de se aposentar: "E eu ganhei muito dinheiro, trabalhei muito na minha vida com datilografia, e aí foi indo, eu aposentei na Siemens, eu fui indo".

Depois da dedicação de toda uma vida ao trabalho formal, fora de casa e ao trabalho doméstico, a aposentadoria se torna o momento de maior tempo de ociosidade que passa a ser usufruído no CEU. “Antes de entrar no Conselho Gestor, eu trabalhava em empresa, eu trabalhava fora, aí quando eu me aposentei eu resolvi vir para o CEU".

Já, Mariana, desde que soube da existência do Conselho Gestor do CEU, teve interesse em conhecer o colegiado:

Sempre tive, tive um filho para cuidar, marido, casa para cuidar, então as coisas ficavam bem apertada para poder fazer, mas quando eu aposentei não, aí 2009 eu me aposentei, não trabalhei mais fora, só serviço de casa, e fazendo minhas atividades aqui.

Contudo, além do emprego com carteira de trabalho assinada em uma metalúrgica, ela ainda era a responsável pelos afazeres de casa, cuidado do filho e do marido, sem contar 
no tempo de deslocamento casa-trabalho, que a impossibilitava de chegar a tempo no CEU durante o horário de funcionamento. Foi somente em 2009, após se aposentar, que começou a frequentar as atividades do equipamento.

As entrevistas realizadas para esta pesquisa confirmam que as mulheres passam a frequentar mais o CEU e a se dedicar ao Conselho Gestor quando deixam de trabalhar fora de casa. Esse trabalho formal, aliado ao acúmulo do tempo dispendido no trabalho doméstico, na criação dos filhos, cuidado com marido, com pais que envelhecem, e exigem mais atenção, além do tempo aos estudos, impedem de elas se dedicarem a outras atividades.

É nesse período que as mulheres deixam de exercer atividade remunerada fora de casa, deixam de ser as responsáveis pela criação de seus filhos e no cuidado de pais e mães, que já são falecidos, que encontram tempo de dedicação nas atividades do CEU.

No caso da Lilian, mesmo com a morte da mãe, herdou a responsabilidade pelo cuidado dos bichos de estimação:

Tinha tartaruga. Porque foi assim, eu tinha meus bichinhos, mas a minha mãe também tinha e a minha mãe faleceu. Aí eu trouxe os bichinhos da minha mãe para minha casa. Agora eles já estão tudo velhinhos, tem que cuidar. E eu cuido, cuido deles, faço tudo de manhã para na hora da minha reunião eu estar livre.

A participação no CEU também pode, excepcionalmente, ser antecipada, por exemplo a Renata, que exerce com exclusividade a função de dona de casa. Apesar de ter ensino médio completo, não exerceu atividade remunerada fora do domicílio. Ela conta que, após o casamento, teve o primeiro filho:

Casei com dezessete para dezoito anos. Tenho um filho de dezoito, vai fazer dezenove. Tenho um de quatorze anos e tenho um de oito que estuda aqui no equipamento.

Outra justificativa que corrobora para a atuação delas no CEU é a inserção no mercado de trabalho informal:

Eu trabalho em casa, desde 90 . Vamos pôr desde 2000 eu não trabalho mais, assim, registrada. Daí eu trabalho em casa. Logo que surgiu o CEU, eu sempre participei da parte de esporte.

A fala de Mercedes a seguir reproduz a estratégia de vida de mulheres com filhos pequenos. Muitas abandonam o mercado de trabalho formal para se dedicarem ao cuidado dos filhos pequenos enquanto o marido é o principal responsável pelo provimento financeiro do seu grupo familiar. Mercedes buscava conciliar a jornada de cuidado dos filhos com o tempo disponível para a prática de atividades esportivas no CEU. "Meu marido 
sempre trabalhou. Mas, com os filhos pequenos, daí eu tentei conciliar os horários". Segundo artigo sobre o trabalho doméstico, Cristina Bruschini (2006, p. 348) aponta que na análise do tempo de dedicação aos afazeres domésticos, os dados estatísticos mostram que "os filhos pequenos são aqueles que consomem o maior número de horas de dedicação aos afazeres domésticos". Ao observar a faixa etária do último filho vivo, ela diz que as mães dedicam 35 horas aos afazeres domésticos, aproximadamente, incluindo nessa gama de tarefas o cuidado com o menor de até 2 anos de idade.

Para as mulheres entrevistadas, o término do período de trabalho remunerado fora de casa pode ocorrer por diversas razões. No caso de Mariana e Lilian, após uma vida inteira dedicada ao trabalho, a aposentadoria chegou após o cumprimento do tempo de serviço. Para Nair e Mercedes, o fim do ciclo de trabalho fora de casa ocorre em um momento da vida que exige cuidados, seja por motivos de saúde quanto de ficarem delegadas à responsabilidade pela criação dos filhos. Além de conselheiras, Nair e Mercedes são também mães, filhas, esposas, autônomas, donas de casa e mulheres periféricas que adotaram estratégias que evidenciam questões fundamentais para a análise.

O tema do trabalho doméstico perpassa todas as falas das entrevistadas. Embora a concessão do benefício da aposentadoria represente o reconhecimento social do tempo de contribuição para as trabalhadoras, é bom lembrar que mesmo aposentadas as mulheres continuam a desempenhar atividades domésticas sem remuneração, sem valorização e reconhecimento social.

\subsubsection{Eu tive que lutar para o CEU vir pra cá}

A história de construção do CEU é marcada pela resistência de mães e mulheres organizadas, na busca por vagas nas escolas da região, passando pela coleta de assinatura de abaixo assinado.

Lilian foi a única entrevistada que participou da criação do CEU, de forma mais intensa. Em mais de um momento, Lilian destaca ter sido a responsável pela construção da sua casa própria, em um terreno de pasto, local onde não havia nada, em 1988: "Comprei aqui isso era um pasto. Não tinha nada aqui, nada aquela época. Aí fiz minha casa”. Após adquirir problema de saúde e ter se aposentado, com filhos pequenos sob sua responsabilidade, conseguiu forças para se engajar no movimento de bairro de apoio ao CEU, 2005. E completa:

Eu aposentei e na época que meu filho foi para escola aqui não tinha vaga para todo mundo, não tinha do $\mathrm{CDHU}$, e as escolas não tinham onde 
suportar tanta criança. Aí me chamaram para ajudar que viria o CEU para cá.

Uma das formas de participação na trajetória de muitas mulheres pode ocorrer por meio de sua preocupação com a educação de filhos/as (VIANNA, 1992). Não se pode ignorar a existência da luta por uma estratégia de vida, principalmente na periferia, para que os filhos e filhas possam estudar em locais próximos a suas moradias. Considerando a escassez de recursos financeiros e de modalidades no transporte público local, que possa atender aos circuitos casa-trabalho-escola, as mulheres optam por instalações educacionais estrategicamente localizadas. Em apoio a essa afirmação, temos o seguinte trecho da entrevistada Lilian:

Então, aí ele foi caí numa escola muito longe, ele foi para o Aldo Ribeiro que era longe, ele tinha problema de mobilidade. Aí surgiu essa oportunidade de vir o CEU para cá. Na época eu trabalhei muito, ia de porta em porta pedia abaixo assinado, para esse CEU vir para cá, eles queriam que mandasse para longe, e as crianças daqui não tinham escola. Não o suficiente, o Veríssimo não suportava tanta criança. Aí eu tive que trabalhar, eu tive que lutar para o CEU vir para cá, então isso aqui é meu. Eu tenho isso aqui como meu, assim. E mesmo assim eu nunca consegui colocar meu filho aqui.

Percebi que o envolvimento de Lilian com o CEU começou muito antes da construção, quando ela reivindicava no estabelecimento educacional matrícula para o seu filho. Não é possível saber se o problema de mobilidade a que Lilian se refere diz respeito à falta de transporte público na região ou ao seu problema de saúde, já que sofre de esclerose múltipla, o que dificulta sua mobilidade pelo bairro para transportar seu filho menor até a escola. De qualquer forma, evidencia obstáculos, seja de caráter social (transporte) ou individual (doença), que foram considerados em sua escolha.

Renata, por sua vez, chega a mencionar a péssima qualidade dos ônibus públicos que circulam na região: "Ônibus deteriorados que mandam para a gente aqui, não são linhas de centro, são linhas horrorosas". A condição de vida das mulheres do bairro também é ressaltada por Nair:

Aqui eu percebo que as mulheres vão mesmo à luta, pegam as suas crianças de manhã, deixam aqui no CEU. [...] Aí eu vejo essa mulher daqui a pouco descer, pegar um trem, e vai trabalhar, daqui a pouco eu olho, à tarde, eu a vejo subindo para fazer o EJA. Então eu acho isso tremendo, assim, acho, assim, muito legal. Eu acho as mulheres muito fortes.

Lilian chegou ao Conselho Gestor após ter se aposentado, com estímulo de que seu filho pudesse estudar no CEU, que seria inaugurado na localidade, no início dos anos 2000. 
Seu objetivo era mantê-lo matriculado no equipamento educacional recém-inaugurado, próximo de sua residência, considerando seu problema de saúde, que dificultava sua mobilidade no bairro, para levar e buscar seu filho na escola. A conselheira, que convive com o problema de esclerose múltipla e com três filhos, dos quais um era menor de idade na época, buscava uma escola próxima de sua residência, para facilitar sua mobilidade no transporte de filho da escola para casa, e vice-versa, diariamente. Ela viu no projeto de construção do CEU uma oportunidade para sua vida. Segundo Lilian, era insuficiente a oferta de estabelecimentos educacionais na região para a demanda de crianças, e a ameaça do projeto do CEU se abrigar em outra localidade fez com que ela fosse à luta para que o prédio fosse erguido na atual localidade. Para isso, ela se engajou na luta pela educação e passou a circular de porta em porta nas residências do bairro para que os moradores compreendessem a reivindicação e assinassem a petição.

\subsubsection{O que é participar do Conselho Gestor, para que serve e para que deveria servir}

Embora o comentário de Lilian abaixo não seja nenhuma novidade, já que descreve uma etapa da regra de participação para o cargo de presidência do Conselho, revela elementos que são importantes na atuação e a função de presidência, de pouco interesse da conselheira:

Depois os eleitos escolhiam a presidência, que era por votação também. Mas eu não quis saber, não quis mais, pois já faço parte do Conselho, ser presidente eu não quero mais. Toda vez tem reunião, eu venho eu participo, eu tenho direito a voto e às questões que acontecem, aí a gente vota.

$\mathrm{Na}$ passagem, "mas eu não quis saber" mostra que a escolha por participar da seleção do cargo da presidência do Conselho era facultativa aos candidatos e candidatas $\mathrm{O}$ relato evidencia que Lilian já teria ocupado o cargo na presidência do Conselho, motivo de não querer exercê-lo novamente: "ser presidente eu não quero mais". Na observância da ata de reunião do Conselho Gestor, do dia 11 de junho de 2014, consta que após a apresentação da representação de eleitos "houve a escolha" de Lilian para o cargo de Presidência do Conselho Gestor. Ainda segundo a ata, a decisão baseada em Art. 4 do Decreto $\mathrm{n}^{\mathrm{o}}$ 50.738/09, que foi revogado pelo Decreto $\mathrm{n}^{\circ} 57.478$, de 2016, passou a determinar que a vice-Presidência "automaticamente substituirá o Presidente nas suas ausências e/ou impedimentos”.

Além de mencionar a existência do cargo de presidente, Lilian destaca outra característica do Conselho Gestor: seu caráter deliberativo, além de consultivo. É 
importante ressalvar que o Decreto $\mathrm{n}^{\mathrm{o}} 57.478$, de 28 de novembro de 2016, aprova o Regimento Padrão dos Centros Educacionais Unificados - CEUs, vinculados à Secretaria Municipal de Educação. De acordo com a normativa, em seu artigo 34, o Conselho Gestor do CEU é um colegiado de natureza consultiva e deliberativa, que deve promover a "participação, organização e controle social sobre os instrumentos de execução das políticas públicas do CEU, como instância máxima de decisão de caráter permanente, respeitadas as competências do poder público municipal e os limites da legislação vigente, assim como atuar na defesa dos interesses dos bebês, das crianças, adolescentes e população do território." Feita essa ressalva, é possível entender a dimensão do Conselho Gestor e sua importância para a comunidade em seu entorno.

O registro da ata da reunião do dia 18 de junho de 2015 evidencia a importância dada ao caráter democrático pelos participantes. Em momento em que se decide pela adoção de barracas em evento no CEU, em curto espaço de tempo, para a circulação de edital de convocação, uma integrante do fórum sugere uma votação após avaliação para que o encaminhamento fosse respaldado pela participação de todos/as:

Sonia ${ }^{11}$ sugeriu que fosse feito (sic) uma avaliação de todos das barracas selecionadas para a virada cultural, seguida de uma votação de todos os presentes na reunião, para que o processo fosse democrático. (Ata de $18 / 06 / 15)$

Tomando como base o conjunto de fragmentos das mulheres conselheiras do CEU, é possível ter uma dimensão da funcionalidade do fórum comunitário do Centro Educacional Unificado. Mariana e Nair trouxeram elementos que corroboram uma característica do Conselho: a falta de comunicação. Seguramente, a nova gestão tem feito um esforço para sanar o problema. Segundo Mariana:

Agora o Conselho está se levantando de novo. Do ano passado para cá teve uma diferença grande. Então eu fico pensando assim, assim ele tem que andar mais, porque se a gente está no Conselho, eu não tenho diálogo contigo, e não tenho diálogo com aquela outra pessoa, não tem como ele, ir para frente. E não é agora, agora com essa gestão que nós temos agora, o plano é estar sempre juntos, quando tem alguma coisa, a diretora nunca está ocupada para você, você quer falar com ela.

Talvez por ser uma das conselheiras mais antigas, Mariana enfatiza que a postura da nova gestão em ampliar o espaço de diálogo junto à comunidade é benéfica e propicia um espaço de diálogo inexistente na gestão anterior:

\footnotetext{
${ }^{11}$ Os nomes das pessoas mencionadas foram alterados.
} 
Ela tem tempo para falar contigo, para te receber, porque eu acho que a coisa pior que tem é você chegar para mim, Mariana eu preciso falar contigo e eu respondo, "hoje não dá, deixa para depois". E aí vai correndo, foi o que aconteceu nesses quatro anos atrás, de ter meses, nós temos uma reunião por mês, de ter meses que não tínhamos nem a reunião, nós ficamos três quatro meses sem assinar o currículo. $\mathrm{O}$ que acontecia dentro do CEU por exemplo, que tem as festas, que a gente recolhe as coisas, a gente tem a arrecadação, a gente tem que saber o quanto arrecadou, o quanto gastou, tudo a gente tem que saber, é sabido. Não sabia nada. Não sabia quanto entrava nem quanto saia... o ano passado para cá eu já vi a diferença, que gente já está sabendo as coisas. Então eu acho que a tendência que tem é crescer.

Já a percepção da função do Conselho Gestor, para Mercedes, abarca não só um espaço de promoção da participação cidadã, que tem a responsabilidade pela fiscalização e zeladoria do prédio, mas da atuação da fiscalização dos funcionários, principalmente o quadro da administração pública ocupado pelos cargos de comissão e funções de confiança, tema caro para a conselheira. Ao longo de sua entrevista, Mercedes mostrou ser contrária ao provimento de cargos de livre nomeação, principalmente, no CEU. A conselheira relata fiscalizar a jornada de trabalho dos funcionários públicos em horário de expediente: "E eu vou denunciar mesmo, 'fia', eu vou direto na ouvidoria. Até vir alguém fiscalizar mesmo".

$\mathrm{Na}$ ata de reunião do Conselho, de 14 de março de 2016, observei a cobrança que Mercedes faz junto a gestão sobre tema de zeladoria do CEU:

O gestor cita ainda que estávamos com problema muito forte com a iluminação da área externa, que o serviço foi retomado hoje e vai estar regularizando semana que vem, quando o prestador volta para arrumar a iluminação da escada de emergência. Mercedes diz que a poda feita pela prefeitura na semana passada não podou suficientemente as árvores, o que prejudica a iluminação. Sandro diz que vai fazer contato na subprefeitura e pedir a poda e a verificação da iluminação externa. (Ata de 14/03/16)

O registro da ata prossegue denotando a atuação de Mercedes no colegiado frente às colocações do gestor da ocasião. As intervenções são referentes ao tema da zeladoria do prédio. Embora a gestão procure saber se os participantes observaram algum problema na infraestrutura, a intervenção da gestão tem o caráter informativo e de prestação de contas ao passo que a atuação da representação da comunidade é caracterizada pela cobrança de ações:

O gestor relata que está vendo com os grupos a prioridade para as obras de melhoria, pois há questões que podem aguardar e questões emergenciais como as luminárias, como antes onde a prioridade foram as grelhas. Mercedes questiona sobre as grelhas atrás do teatro. $\mathrm{O}$ gestor informa que quando foi feita a avaliação, aquelas estavam em boas condições e que estavam sendo reaproveitadas grelhas da obra da piscina. $\mathrm{O}$ gestor pergunta aos presentes se tem algum problema de infraestrutura 
que tenham notado. Mercedes fala do vestiário feminino, ao que o gestor responde que foi feita a recuperação do piso, troca das portas e pintura, e que, assim que for finalizado será liberado ao uso da comunidade. Mercedes sugere que seria interessante que o vestiário ficasse fechado e que os profissionais de educação física possuíssem a chave para abrir os vestiários somente em horários de aula, para evitar que as crianças fiquem se escondendo lá dentro. (Ata de 14/03/16)

Conforme o registro, a gestão se coloca à disposição para saber se as participantes do Conselho apontam problemas existentes de "infraestrutura" no CEU, o que as coloca em uma tarefa investigativa de problemas de manutenção do prédio. Outro trecho da mesma ata corrobora a observação na intervenção de Lilian. O gestor atua como um ouvidor de demandas e reclamações da comunidade:

Em relação aos espelhos da sala de dança, Lilian sugere que sejam colocados suportes nos cantos dos espelhos que por serem muito pesados, descolam da parede. O gestor informa que vai verificar a possibilidade junto ao prestador de serviço. (Ata de 14/03/16)

O tema da segurança pauta a discussão no Conselho, como observado no registro em ata abaixo. Observei, também, que até o registro da ata, feito por funcionárias do CEU, tem uma tendência e preocupação em deixar claro o encaminhamento da gestão. A redação do documento tem uma preocupação em esclarecer o posicionamento da gestão, em comparação às pontuações levantadas pelas conselheiras:

César traz a questão das pessoas que circulam nos corredores das salas de aula da EMEI. O gestor esclarece que isso já foi pauta constante do ano passado e que foi feita reorganização e categorização das pessoas que poderiam ter acesso por lá, com o uso de uma carteirinha especial na cor amarela. O gestor frisa que há questão da segurança é priorizada, mas que é preciso aprender a conviver, pois estamos num espaço multicultural. César diz que a EMEI possui um número reduzido de funcionários e que é complexo, que tem noção que não há como cessar a circulação de pessoas, mas fala de critério da conscientização de ambos os lados, entendendo que algumas pessoas precisam de acessibilidade facilitada. Mariana diz que tem gente que não possui a carteirinha amarela e tem acesso por lá. O gestor informa que vai reforçar as orientações junto a equipe de segurança. (Ata de 14/03/16)

Conforme exposto por outros participantes no registro da ata acima, o tema da segurança e acesso ao CEU foi também observado por Mercedes durante a entrevista. $\mathrm{O}$ problema do acesso ao prédio foi resolvido com uma identificação distinta concedida a um grupo menor de moradores da rua de cima para que pudessem acessar o prédio pelo outro portão, mais próximos de sua residência, reivindicação antiga no Conselho:

Só os funcionários. Mas daí eu questionei muito, porque tem muita gente de idade... que vem de lá de cima. E não tinha cabimento eles darem a 
volta, para entrar para cá. Daí fizeram uma carteirinha diferenciada, que... Tem pessoas que tem problemas de saúde. Para ficar subindo escada e tudo mais. Fizeram uma carteirinha diferenciada, para eles poder terem acesso.

Mesmo com a resolução do impasse junto à comunidade no acesso ao prédio, restava ainda outro tema que foi colocado por Nair em sua entrevista que diz respeito ao acesso de um outro grupo de moradores que não está acostumado a frequentar o prédio. A reflexão de Nair se dirige ao público que não pertence à comunidade do $\mathrm{CEU}$, mas que é um potencial futuro frequentador. Para a conselheira, a exigência de identificação no acesso ao CEU sinaliza obstáculo à participação da população:

Então, isso já foi conversado, várias formas; eu não sei nessa gestão, na outra gestão para que a gente mudasse isso no sentido de... porque, para mim a questão mesmo de você... Eu não quero usar essa palavra, "apropriação", mas você tem que entender que isso é parte das pessoas, que as pessoas podem ter acesso. Então, para mim, para o Seu João, que ele trabalha ali na fábrica, não sei o que, não sei o que, para ele entrar aqui é muito difícil; e, se ele encontrar algum tipo de barreira, ele não vai voltar.

Assim como ela descreve, o problema de acesso ao prédio já havia sido pauta das reuniões da gestão anterior, a mesma gestão a que se refere a ata de 14 de março de 2016.

Desde sua criação, a concepção inicial do projeto dos Centros Educacionais Unificados considera que "a ação educativa é norteada pelos princípios da participação, descentralização e autonomia, bem como da inclusão, não só escolar, mas também socioeconômica da população" (SÃO PAULO, 2003). Sendo assim, os trechos e análises a seguir fazem referência à noção ideal de funcionalidade do equipamento, isto é, pela qual o Centro Educacional Unificado deveria servir, considerando sua localização estratégica territorial no atendimento para a "reversão do quadro de exclusão social, cultural, tecnológica e educacional", conforme especificações do Decreto $\mathrm{n}^{\mathrm{o}} 42.832$, de 06 de fevereiro de 2003. (SÃO PAULO, 2003).

Dá para perceber, na fala a seguir, o caráter formativo da participação. Mariana menciona a importância de ouvir e compreender que a interação é característica desejada não somente no espaço do Conselho: "E nem só no Conselho, em qualquer lugar que você vai participar de qualquer reunião, um diálogo que você tem, primeiro você tem que ouvir para entender para depois você falar".

Ainda segundo Mariana, deveriam existir mais espaços de participação política para que as pessoas possam se apropriar de um conhecimento que não é somente teórico acerca da política, mas de conhecimento prático. 
Eu acho que deveria ter mais política assim, mais gente que entendesse da política. Eu acho que até, todos os lugares precisam de uma política, de a gente ter um conhecimento, porque não adianta você dizer, falar em política e muita gente não conhecer a política.

Enquanto Mariana acredita que as pessoas devessem acessar um conhecimento prático do que é a política, o relato abaixo de Lilian observa que deveria existir maior envolvimento de pessoas nas questões da comunidade. Sobre sua visão a respeito da participação das mulheres no CEU, ela completa:

Bem pouco. E pelo quanto de criança que tem aqui no CEU, eu acho que deveria ser bastante.

Participar do CEU, para Lilian, é ser participativa/o com a educação não formal dos filhos, ou seja, é estar envolvido e presente na criação dos filhos/as. Uma vez que seu entendimento acerca da participação no CEU se refere à presença na vida escolar das crianças, ela entende ser necessário o chamado junto aos seus próprios familiares.

Em atendimento à demanda da comunidade pela realização de reuniões do Conselho Gestor fora do horário de trabalho, aos sábados, o trecho seguinte faz parte da Ata da Reunião do Conselho Gestor do CEU do dia 01 de agosto de 2015, e evidencia estratégia da gestão em aproximar a comunidade que, usualmente, não pode participar das reuniões do Conselho durante os dias da semana:

Esta reunião foi uma solicitação das famílias pertencentes às unidades escolares, que pelo menos a cada três meses acontecesse reuniões do Conselho Gestor aos sábados, para atender a (sic) solicitação, a Gestão separou a pauta em dois momentos, uma apresentação dos trabalhos que já acontecem no CEU e um momento de escuta. (Ata de 01/08/15)

Além da dificuldade de compreensão e de expressão no espaço do colegiado, Nair observou a falta de tempo e de integração entre as mulheres para conversa antes da reunião do Conselho, e ela lamenta não ter sido capaz de reuni-las. Ela chama atenção para a pouca divulgação das ações do CEU na comunidade, o que amplia o desconhecimento da população ao redor do espaço. A gestão, na ocasião, fez a mea culpa sobre o problema da falta de comunicação:

Dona Nair cita que vem participando de várias reuniões externas e sempre se depara com o mesmo discurso "a falta de uma cultura na nossa região", e sempre faz questão de divulgar as ações que acontecem na nossa região, que poucos conhecem. Marcos fala um pouco da nossa falha quanto comunicação, que é algo que estamos trabalhando. (Ata de 01/08/15)

Durante a entrevista, no trecho abaixo, Nair não somente aponta o problema da falta de comunicação no equipamento educacional, de um modo geral, assim como percebe que 
essa falta de entendimento é a raiz dos problemas. Como já observado, a comunidade participa quando a reunião é remanejada aos sábados. O que corrobora a tese de Nair de que não há uma falta de interesse das pessoas em participar, mas limitações em se apropriar do espaço e do próprio conhecimento sobre o sentido da participação. É justamente isso que ela quer dizer com a necessidade de um "entender mais humano":

Então, quando eu digo, assim, da falta de comunicação, eu não digo exatamente deste local, eu digo de todos; porque, se não funciona, é porque está tendo algumas questões aí que tem que ser revista. Eu não vejo, como eu falei, volto a falar: eu não vejo que há falta de interesse, eu vejo que há falta de entendimento e uma comunicação e uma... como eu poderia dizer para você? Eu acho que é um entender mais humano, mais humano, você está entendendo. (Nair)

\subsection{A PARTICIPAÇÃO NO CONSELHO GESTOR DO CEU: CONTRIBUIÇÕES E CONFLITOS}

Neste momento procuro delinear como cada entrevistada percebe as dificuldades e as contribuições da participação no Conselho Gestor em suas vidas. A fim de averiguar as barreiras que as conselheiras vivenciam, tanto no espaço público quando no privado, procuro dar especial atenção às tensões e dificuldades relatadas que permeiam suas vidas e intrínsecas, muitas vezes, do processo participativo. As partir das experiências coletivas relatadas, ressalto as contribuições e as consequências positivas que trouxeram benefício a partir da forma de organização coletiva popular no CEU.

\subsubsection{Era tudo eu, comida, roupa, a limpeza da casa}

As mulheres entrevistadas trouxeram poucos relatos de divergências familiares, todavia, quando esse tema era mencionado, girava em torno da divisão desigual de afazeres domésticos. As festividades ocorridas no espaço público do CEU são palcos de conflitos, como a tensão entre as participantes por espaço para montar a barraca.

Tanto a conselheira Nair como a Lilian relataram algo nesse sentido, embora o conflito descrito por Nair tenha sido mais evidente. Ambas as falas não mencionaram nenhum impedimento explicitamente sofrido pela participação das atividades no CEU. Entretanto, o marido de Nair prefere vê-la em casa. Mesmo que Nair relate não ter sofrido nenhum impedimento explícito do marido por vê-la participar das atividades no CEU, ela lembra que precisou se posicionar diante da vontade dele de vê-la em casa para servi-lo: "Meu marido, ele gosta, mas, se ele puder me segurar lá para esquentar a comida para ele, ele vai querer". Segundo ela, o esposo não manifesta diretamente sua contrariedade em vêla no CEU, pois ele entende que não é correto se opor à sua participação. Entretanto, se 
porventura ela lhe perguntar da necessidade de "esquentar" a comida, certamente o desejo do marido será que ela permaneça em casa.

A conselheira Lilian não relatou explicitamente nenhum estranhamento familiar, mas no período em que seu filho e nora moravam em sua residência, a conselheira era a responsável por todos os afazeres domésticos e pelo pagamento das contas de luz, água e outras:

Tudo eu. Porque eles trabalham, a minha nora além de trabalhar fazia faculdade, agora ela já se formou. Então era tudo eu. Comida, roupa, a limpeza da casa...

Embora Lilian não relate nenhum conflito aberto com os jovens recém-casados, ela expõe uma realidade desigual de divisão do trabalho doméstico em sua residência:

O meu filho nunca ajudou em nada, nem minha nora, então sempre fui ele na parte de alimentação e eu sempre com água, luz, telefone, tudo eu.

É interessante notar a associação feita por Nair, entre os problemas de sua rotina e do casamento. Primeiramente, relata a existência de inúmeras brigas com seu cônjuge pela reivindicação da sua liberdade. Em segundo lugar, a conselheira percebe que as brigas são saudáveis em uma relação, na passagem: "aprendi que onde não há briga, não é porque as pessoas vivem bem". Interessa da análise de Roberto DaMatta a compreensão das contradições permitidas nas entidades da rua, ao contrário do espaço do lar: "De fato, na rua podem-se admitir contradições próprias deste espaço. Mas na casa as contradições devem ser banidas, sob pena de causarem um intolerável mal-estar." (DAMATTA, 1997, p. 39)

Para a conselheira, a passividade de não entrar em embates é visto como algo negativo, o que leva a entender, por exclusão, que o contrário é positivo. Ou seja, de acordo com Nair, o embate e a briga têm um significado positivo. Essa sua percepção é importante para entender sua atuação no Conselho e seus enfrentamentos naquele espaço:

Eu tive muitos problemas em questão a casamento. Eu e meu marido, a gente brigou muito. Mas você sabe que hoje a gente vive muito bem. Assim, no sentido de eu ter liberdade. É porque eu também aprendi que onde não há briga, não é porque as pessoas vivem bem, você entendeu? É porque as pessoas se calam. E quando você, quer alguma coisa a mais, você tem que brigar.

A experiência de brigas com o esposo, na ocasião da entrevista, já era inexistente: “Agora, é difícil você brigar e tal, mas a gente passou por isso, então".

A maneira como as mulheres experimentam os conflitos familiares, em contraste com a outra parte conflitante, possibilita compreender que suas reivindicações são comuns, 
ou seja, reivindicam a divisão equitativa das atividades domésticas junto aos outros moradores. Também notei que o outro lado que elas entram em conflito, costumeiramente, pertence ao sexo masculino.

\subsubsection{De vez em quando Deus me tira a poesia, olho pedra, vejo pedra mesmo}

Este tópico concentra vários relatos das conselheiras que reclamam da falta de escuta e de aproximação vivenciados no Centro Educacional. Por esse motivo, esse tópico tem relevância para a pesquisa. Parti do pressuposto de que ao participar do Conselho Gestor as mulheres vivenciam desigualdades sociais e de gênero que interferem nessa participação. Pelas entrevistas, procurei compreender como a participação influencia a vida dessas mulheres e verificar os fatores que favorecem e/ou limitam essa participação.

Logo no início da entrevista com Nair, percebi que o seu entendimento de educação abarcava um conjunto de responsabilidades, que envolvem todos os indivíduos. Ela lembrou se encontrar em uma fase mais dura, crítica e de ataque ao sistema em funcionamento do CEU. Também foi a entrevistada que mais trouxe elementos vivenciados no Centro Educacional de crítica ao modelo vigente, que deixa de ouvir os/as participantes que acessam ao equipamento e se distancia da população:

Engraçado que ontem eu estava pensando sobre a nossa entrevista e me lembrei de uma poesia, de um trecho ou de uma frase da Adélia Prado que falava assim, que 'De vez em quando Deus me tira a poesia. Olho pedra, vejo pedra mesmo'. Então, eu acho que, se você chegasse para mim há dois ou três anos atrás, eu acho que eu ia ter um pouquinho mais de poesia para te falar. Hoje eu tenho um pouquinho mais de pedra nas mãos. Eu sempre entendi que a educação é um conjunto porque ela é uma responsabilidade de todos. Pelo menos nos meios onde eu passei, isso me fez entender dessa forma. Então, eu entendo que eu tenho responsabilidade sobre esta região, sobre quem está próximo de mim.

Ao contrário da sua atual condição, de ataque com "pedra nas mãos", em referência ao poema "Paixão", de Adélia Prado (1999), Nair diz que se fosse entrevistada dois ou três anos atrás estaria mais na condição de "poesia", isto é, menos crítica. Em outras palavras, quando ela chama atenção para a necessidade de seu dever perante a comunidade, também coloca a responsabilidade nas costas dos educadores do Centro Educacional. Segundo Nair, cabe aos profissionais da educação do CEU, devido ao preparo e formação que possuem, a obrigação pela receptividade e compreensão das pessoas que chegam ao equipamento, muitas delas desprovidas de conhecimento e formação educacional.

Então, lembra que eu falei para você sobre a 'deformidade das pessoas'? Que eu acho que a pessoa, enquanto ela está aqui, e ele é um gestor e ele 
tem um nível que compreende, ele tem que entender aquela pessoa. Porque como eu disse para você: todo mundo participa. Então vão vir pessoas com deformidades, mas a questão não é o quanto ela quer participar. E a pessoa que está aqui, por ela ter uma formação maior, ela tem que entender aonde ela pode encaixar aquela pessoa. Não aquela pessoa se sentir excluída a ponto de não querer voltar, ou a ponto de achar que ela não é necessária ali, ou ela não pode participar. (Nair)

Logo no início da entrevista, Nair usa a metáfora da deformação para remeter às pessoas que possuem alguma falta de conhecimento o que gera limitação. Teve os primeiros contatos com a "deformação" ainda durante sua experiência profissional em um hospital, experiência essa que a marcou pelo resto da vida. Segundo Nair, as deformações não se restringem ao físico, mas as condições impostas pela vida àquelas pessoas. Então, a "deformidade" estaria associada a um desvio que tende a pior, principalmente se a própria instituição educacional fizer acepção de pessoas, conforme ela destaca a seguir: "Não aquela pessoa se sentir excluída a ponto de não querer voltar, ou a ponto de achar que ela não é necessária ali, ou ela não pode participar”.

Um tipo de reclamação que é recorrente no conjunto das entrevistas é a da falta de reconhecimento da instituição educacional diante das pessoas com menos estudos e formação. De acordo com a conselheira, falta ao CEU valorizar a participação também dos usuários e usuárias que ali chegam e que não tiveram acesso à educação, ao longo de suas vidas, a fim de não aprofundar mais a exclusão para essas pessoas.

Nair critica o modelo de educação vigente que não reconhece e exclui as pessoas sem escolaridade da participação cidadã, modelo que ignora a cultura oral, a riqueza de saberes, a vivência prática e da troca de experiências entre as gerações e culturas distintas:

Então se a escola, o modelo de educação tivesse 'certo', eu não me depararia com aquilo que eu me deparei essa semana na escola, apesar de todas essas mudanças. Eu acho que falta um pouco isso. Falta essa engrenagem, no sentido dessa vivência. E eu acho que quando você barra uma pessoa, o Seu João, por ele quer participar, mas ele não sabe falar, ele não tem um, ele talvez nem entenda aquilo que você está falando. $\mathrm{E}$ você olha assim: 'Ih, o Seu Antônio não dá, não'; não sabe nem falar. Mas às vezes o Seu João deve saber usar as mãos de uma forma que nenhum aqui formado saiba e que que ele pode ajudar nisso, está entendendo? Por exemplo, é que ele pode contar histórias para as crianças, às vezes ele tem umas histórias, assim, da cultura dele e como que a gente pode colocar, inserir o Seu João para que amanhã essa criança esteja no meio da rua e você passe ali e veja ela no escadão, ali, e ele ali e ele veja o Seu João e o Seu João veja ele e fale 'Não, não faz isso não! Cadê seu pai, cadê sua mãe?' E para que eles se reconheçam, e um possa ajudar o outro. Então teve isso, eu encontrei, então tem muita barreira mesmo. (Nair) 
A ideia que Nair transmite é a de que por mais que a pessoa sem estudo pareça não poder contribuir na sociedade, ainda assim ela tem algo a fornecer, seja por meio de sua vivência ou experiência a ser compartilhada com outros. E é justamente essa troca que é primordial para o processo educativo, como ela diz na seguinte passagem: "para que eles se reconheçam, e um possa ajudar o outro.”. Ela chama atenção para que o acesso à cidadania não se restrinja somente entre os escolarizados.

Esse relato de denúncia da Nair aponta para uma de falta de compreensão da gestão no acolhimento aos participantes do CEU, que deveria confiar visibilidade e reconhecimento a uma parte da sociedade que já se encontram excluídos da sociedade, isto é, daquelas pessoas sem diploma superior. Ao não dar voz àqueles que deveriam ser ouvidos, se reproduz a manutenção da desigualdade. Uma desigualdade que alija do processo educativo informal e participativo as mulheres, conforme veremos nas passagens seguintes.

A contradição do sistema público educacional apontada por Nair é que está em curso um mecanismo de exclusão da cidadania que age no próprio campo educacional ao selecionar somente um grupo seleto, daqueles com escolaridade, e que escamoteia as pessoas que não ascenderam a altos níveis de escolaridade. Contradição essa do sistema que levou Nair a se afastar das reuniões do Conselho Gestor do CEU. A ex-conselheira questiona como o Centro Educacional, composto por profissionais da educação, não estar habilitado a atender aos que não têm formação superior e que chegam para acessar o equipamento:

Você está entendendo? Eles tinham formação suficiente para isso, para entender, e tanto que eu falei, bom, eu vou usar os meus dois dias de outra forma, e é isso que eu estou fazendo.

Devido à dificuldade que encontrou de ser ouvida no Conselho Gestor, Nair fez convite à sua filha, com formação superior na área da Educação e com um "linguajar" que demonstrava ter conhecimento de causa, a participar de uma reunião. Como resultado desse experimento, Nair percebeu que houve receptividade à sua filha, sendo que ambas defendiam as mesmas ideias embora de formas distintas:

Porque ela tinha e ela veio só uma vez, porque eu falei, não, não é possível! Porque nós tínhamos um grupo de mulheres, e a gente. Nós vamos fazer isso, vamos fazer aquilo. E eu falei, gente, está muito difícil lá para mim, está muito difícil. Eu pedi para minha filha vir, para que ela tivesse um olhar, assim. 
Como já observado acima, quando a conselheira Nair teve dificuldades de ter sua voz ouvida no espaço, solicitou participação de sua filha, que possuía formação superior na área educacional. Sua filha esteve presente na reunião do Conselho Gestor do CEU e defendeu os mesmos pontos de vista que sua mãe havia feito em reuniões anteriores. A diferença é: enquanto Nair teve dificuldade em ser reconhecida e ouvida no espaço, sua filha obteve a receptividade do grupo e foi ouvida:

Primeiro que eu percebi que para você ser ouvida, efetivamente, você tem que ter uma formação. Se você não tem uma formação você não é ouvida ou não é levado muito em consideração o que você fala. Acho um grande erro isto. Primeiro, a pessoa não pergunta "quem é você?", e sim pergunta “o que você é?". Se você é, você pode falar alguma coisa. Mas se você não é, você vai falar, mas não causa um efeito tão... (Nair)

A denúncia que Nair fez foi a de não ter sido ouvida pela falta de escolaridade, ao contrário de sua filha, especialmente por ela possuir formação na área da Educação:

Ela sabia dos métodos da educação. Então, ela teve voz. Entendeu? E ela fala as mesmas coisas, ela pensa da mesma forma que eu, mas como eu não tinha essa formação ninguém me ouvia.

A conselheira critica a valorização do diploma em detrimento do conhecimento prático acumulado na comunidade; para ela, a contribuição tanto do conhecimento acadêmico quanto prático são essenciais, assim como também critica a manutenção de uma ordem que não serve à população pois não dialoga com a realidade da comunidade:

Eu não sei se é uma coisa de política, uma coisa de não se abrir, uma coisa de não querer bagunçar o espaço, mas que espaço que não, que ordem é essa que está sendo mantida, que está nessa bagunça toda? Então eu fico pensando nessas coisas.

Para Nair, é necessário que aquele que detém o conhecimento compreenda quem tem dificuldade e acolha, para depois tentar exigir participação das pessoas, por que senão “quando você vai tratar em uma periferia, fica muito difícil. Muito difícil esse tipo de coisa, se as pessoas não entendem e se não tem comunicação, não tem como as coisas irem para frente".

Quando indagada se recomendaria a participação do Conselho a outras mulheres, Nair afirma positivamente e conta ter feito recomendação à amiga, comprovando sua tese de que somente as pessoas com alta escolaridade acessavam ao espaço do Conselho sem impedimentos:

Foi aceita, porque ela tinha uma formação. Ela é formada em teologia e em pedagogia. Eu também acho que ela entendia melhor o discurso deles e ela foi aceita. Se bem que ela é uma pessoa que não pontuava muito, 
porque a própria personalidade dela era de... As mais fortes mesmo não tinham.

Outra observação de Nair, sobre as barreiras existentes no Centro Educacional refere-se à aproximação da comunidade ao CEU em ocasiões de festividades, conforme sua experiência. Embora as festas no CEU sejam os momentos em que os protagonistas do Centro Educacional se encontram e ocorre essa interconexão entre o espaço público e privado, Nair lembra da dificuldade de acessar os docentes. Objetivava estabelecer "contato com algum professor" durante as ocasiões festivas, porque após o evento seria mais difícil. Mesmo que a situação relatada por Nair não ocorra, especificamente, no Conselho Gestor, revela a existência de interesse da população em acessar à educação:

Eu tive um olhar e eu acho que eu não tenho o pior dos olhares, eu não posso ter uma fala muito erudita, mas eu também acredito que eu não tenho o pior dos olhares. Eu percebi muito isso, também, que algumas pessoas... Na hora que eu estava lá eu falava assim, eu queria manter algum contato com algum professor: "Não, tudo bem, tudo bem...", mas depois ninguém atendia no telefone. Podia ligar vinte, trinta, quarenta vezes e ninguém atendia. Mandava e-mail: "Não, você não mandou o email, manda direto..."

A ex-conselheira diz que mesmo não tendo uma "fala muito erudita" ou um conhecimento acadêmico aprofundado não deixa de fazer sua análise. Além da barreira em acessar pessoalmente os docentes da instituição educacional, encontrava dificuldades quando tentava fazer contato por outros meios, como o telefone ou por e-mail.

Até aqui, os depoimentos citados acima mostram os vários obstáculos encontrados em acessar ao Centro Educacional e suas incongruências em possibilitar que os usuários e usuárias participem ativamente do espaço. Em um dos momentos da entrevista, Nair menciona uma das razões pela qual se afastou do colegiado no CEU:

Então eu me afastei, realmente, porque era muita, muita, muita... muita dificuldade, muita dificuldade. Eu quero dizer assim, cooperativismo; você entendia, assim, quando você estava falando alguma coisa, um olhar assim... Parece que...Sabe a impressão que eu tinha? Que já estava tudo estabelecido. E você só estar ali para você falar 'Olha, aqui a gente tem um Conselho Gestor que... tchu-tchu-tchu'... Você está entendendo?

As dificuldades de participação eram muitas, como pude observar nos trechos citados, e foi percebido por ela durante sua permanência no espaço. Para além do que já foi relatado aqui, a ex-conselheira percebia por comportamento e olhares das pessoas, no Conselho, que sua fala não fazia nenhuma diferença, sem a possibilidade de alteração do status quo. Embora os eleitos e eleitas do Conselho Gestor possuam o direito de deliberação no fórum, para além da consulta, Nair percebia que o Conselho se limitava ao caráter 
consultivo, quando dizia que "já estava tudo estabelecido" e, portanto, via sua presença como desnecessária.

Nair classifica a atividade de atuação no Conselho como "cansativa" pelo excesso de diálogo que não chegava à solução comum entre os/as participantes. Também elogia a perseverança de anos de atuação das antigas conselheiras Mariana e Lilian:

Eu tiro o chapéu para a Dona Mariana, por isso que, como eu falei, porque realmente eu acho que falar do Conselho Gestor aqui tem a ver com ela, porque ela está aí, tudo, passa uma gestão, passa outra, passa outra. Ela e a... acho que é a Lúcia, Lurdes, não... Lilian.

Diante das inúmeras dificuldades em participar do CEU e as tentativas de mudança do cenário, Nair revela cansaço e certa revolta diante da desconsideração do CEU em sua luta e de outras mulheres. Tem a sensação de que nada pode ser feito para mudar o status quo:

Se ninguém consegue e se eu não posso ajudar em nada aqui eu não sei o que que está errado comigo? Se a Dona Mariana não consegue ir além, eu não sei? Porque a fulana de tal não consegue, eu não sei?

Mesmo com a significativa quantidade de obstáculos relatados, Nair acredita que inexistam dificuldades, obstáculos e/ou discriminação de gênero, contra a mulher no Conselho Gestor e vê com naturalidade o esforço da mulher em ocupar os espaços de fala e se colocar para que possa ser ouvida: "Mulher sempre tem que falar um pouquinho mais. Eu acho que essa questão da mulher é uma questão que é em todo lugar, para ela se colocar, ela tem que falar um pouquinho mais firme":

Lembra quando eu falei para você, às vezes você tem que abaixar e às vezes você tem que gritar um pouco? Mas eu acho que vai chegar uma hora que você vai poder falar.

Em seu depoimento, percebi a naturalização do esforço da mulher em ser ouvida nos espaços, no trecho que ela diz que "questão da mulher é uma questão que é em todo lugar, para ela se colocar". Ao naturalizar as dificuldades de participação das mulheres, Nair, provavelmente, também deve compreender como natural os obstáculos enfrentados no CEU.

Já a conselheira Renata acredita que as mulheres têm sua voz respeitada no Conselho, mas, quando interrogada se a instância leva em consideração sua fala e opinião, pondera: "algumas coisas" são levadas em consideração. A ponderação de Renata leva a crer que uma parte de suas intervenções no Conselho podem não são consideradas. Opinião que corrobora as críticas de Nair. Renata prossegue, ao afirmar que sua fala é levada em consideração quando em consonância com a fala da gestão: 
Desde que favoreça o quê, muitas vezes, o que a gestora quer e respeito. A partir do momento que a gente já contraria, a gente já começa um debate, ali dentro, e eu acho que isso é que é importante.

Além da necessidade de se impor para poder ser ouvida, Nair coloca outra dificuldade encontrada pelas mulheres no espaço. Observou que as mulheres por não compreenderem o que os demais integrantes do Conselho estavam dizendo, permaneciam caladas: "Não falavam. Elas não entendiam o discurso que elas falavam". E como esses mesmos integrantes do Conselho eram em maior número e sempre se organizavam em trazer as pautas de debate, acabavam tendo suas falas acatadas:

Elas não falavam. Então eu falava assim... Então eles sempre traziam umas pautas, e como eles eram em maior número a votação sempre ia para o lado deles. Sempre eles ganhavam.

Além da dificuldade de compreensão e de expressão no espaço do colegiado, Nair observou que devido à falta de tempo e de integração não foi possível conversar antes da reunião do Conselho.

Não tinha tempo para se conversar. Nós não conversávamos anteriormente então ficava assim, uma olhando para outra: "se eu falar isso..." Eu sempre penso isso, e como eu não consegui unir elas...

Segundo a ex-conselheira, inexistia algum contato prévio da reunião, com o intuito de esclarecer dúvidas, reforçar reclamações e solicitações de demandas e que pudesse indicar o posicionamento que cada representante teria na reunião, facilitando a integração e a construção das pautas. A falta de organização prévia nas reuniões não permitia a integração das mulheres:

Então, você estabelecia com a sua comunidade o que ia acontecer naquele local. O que era melhor para aquele local. Agora, realmente, como é que vai vir aqui um professor, que um mora aqui, uma mora lá na Lapa, outro mora na Freguesia, outro mora não sei o quê? São outras realidades. Eu conheço as pessoas daqui. Você está entendendo? E a gente não conseguiu conversar; então eu acho que a grande questão para mim não é o Conselho Gestor, mas essa falta de união, que não teve e que não era de interesse, por conta de "Ah, eu não gosto da Dona Mariana... A Dona Mariana pinta, ela toma café sem açúcar." Eram essas questões: "então eu não gosto dela". Mas nem questões, assim, porque ninguém nunca viveu na casa do outro, não era pessoal. Mas não tinha essa união. Então, não tinha essa base. Então para mim ficou vago participar de algo assim. Para mim, tudo tem que ter base.

Devido à falta de unidade, união, integração entre as mulheres, as pautas ficavam circunscritas a questões de cunho particular, que não colaboravam em nada para a construção coletiva. Nair destaca a necessidade de criação de base comunitária para a construção coletiva, e devido a essa impossibilidade, assim como outras razões tratadas 
aqui, ela se retirou do Conselho Gestor. Quando atuou no Conselho, percebia a dificuldade de trazer para o encontro pessoas da comunidade. Sendo assim, o problema não estaria no espaço, propriamente dito do Conselho Gestor, mas na falta de união entre os moradores, usuários do $\mathrm{CEU}$ e professores que desconhecem a realidade do bairro.

Outra experiência vivenciada no que motivou o afastamento de Nair do Conselho Gestor foi o não reconhecimento pelo CEU do coletivo de mulheres nele organizado, mesmo após uma matéria jornalística tendo sido publicada em Portugal. O Grupo de Mulheres do CEU era composto por alunas do programa Vocacional de Dança da Prefeitura da Cidade de São Paulo no CEU, e levou esse nome em homenagem ao CEU, inspirado no fenômeno do funk carioca, no início do século XXI, quando do surgimento de mulheres dançarinas com nome de frutas:

Cristiane, quero dizer para você, um desabafo: nós nunca fomos reconhecidas aqui, e saiu publicação da gente em Portugal.

Nair relata que o Centro Educacional recebeu ligação de pessoa do meio artístico interessada em conversar com as mulheres do CEU, entretanto, o funcionário que atendeu ao telefone disse não conhecer as mulheres: “Aí eu fiquei muito chateada, porque esse sempre foi o meu intuito de levar, trazer um olhar para cá. E aí eu falei, bom, acho que está na hora de seguir nosso." A conselheira relata que o coletivo continua a se encontrar, porém fora do prédio do CEU. O grupo "Mulheres do CEU" era formado por mulheres a partir de 14 anos, que compunham o Projeto de artes visuais, música, teatro, dança, vocacional e aldeias com a finalidade de promover a ação e a reflexão sobre a prática artística, cidadania e a ocupação dos espaços públicos da cidade de São Paulo. O grupo, formado em 2008, no CEU, contava com uma equipe de coordenadores e artistas-orientadores contratados anualmente, que atuavam, preferencialmente, em equipamentos da Secretaria Municipal de Cultura e da Secretaria Municipal de Educação de São Paulo. As intervenções de dança e movimentos culturais do "Mulheres do CEU" tinham o objetivo de levar para outras mulheres a mensagem que, independentemente da situação física, psíquica, econômica e social, era possível viver com qualidade, alegria, consciência, produtividade, leveza e felicidade.

Durante o relato sobre o descaso com que a gestão tratou o grupo de dança das Mulheres do CEU, Nair conta o verdadeiro intuito de formação do grupo, o que corrobora a hipótese inicial da pesquisa: 
O foco não era essa coisa da dança, não, porque ninguém tinha e ninguém tem estereótipo, aqui, de bailarina. Ah, se bem que isso não tem nada a ver. Tem de nada disso...

Por detrás da participação seja nos espaços públicos ligado às artes ou na política, o interesse de firmar laços de solidariedade:

É, a vida é uma dança. Era isso que a gente fazia, a gente dançava a vida, cada uma da nossa forma. E esse pessoal aqui do vocacional, eles são tremendos nessa parte. Nos ajudaram muito.

Por fim, na ocasião do término da entrevista, em condição de "mais pedra", Nair avalia não ter tempo para se dedicar ao colegiado do Centro Educacional, mas deixa em aberta a possibilidade de retornar ao CEU:

Eu acho que sempre, você ser participativo em tudo, em tudo é muito importante. Se você tem essa disponibilidade, se você entende. Hoje eu não entendo que o meu tempo seja para isso. Talvez eu possa voltar num tempo mais à frente, talvez algo me faça olhar para cá de volta.

A ex-conselheira confessa ter medo de continuar na condição crítica, de ataque ao sistema, como ela mesmo classifica, de "pedra", preocupada com a situação da (des)humanização da educação:

Não acho que eu falei tudo o que eu tinha que falar. Eu só acho que eu sempre falo demais. O importante é isso mesmo. Eu tenho medo só de continuar nessa situação pedra. Eu acho que a gente tem que ser um pouco, é... Porque eu fico pensando que o saber pode tirar essa humanização de você.

Uma ideia que fica clara no conjunto dos relatos é a de que embora os inúmeros obstáculos vivenciados por elas de ordem institucional, para participar do Conselho Gestor, existe esforço de manutenção do grupo de mulheres no Centro Educacional.

\subsubsection{Desde que os portugueses chegaram aqui, a gente sempre foi mandado}

Os relatos de Renata, Mercedes e Mariana sobre o Conselho Gestor, a sociedade e o CEU expressam indignação diante das desigualdades experimentadas por elas e ajudam na compreensão das relações de poder nesses espaços.

Por mais que cada participante narre sua experiência e denuncie individualmente, percebi, ao cabo, que cada comentário fragmentado compõe a engrenagem da comunidade que se articula no CEU. Há uma via de mão dupla de demandas entre a comunidade e os espaços institucionais que reivindicam a obtenção de reconhecimento, em temas da 
programação da Virada Cultural, o espaço cedido do CEU para as barracas nas festas ou a cobrança de transparência da gestão.

A conselheira Renata fez uma breve análise histórica para explicar as razões pelas quais acredita existir a falta de envolvimento da população nos espaços participativos, como os do Conselho Gestor. Acredita que o déficit de participação seja atribuído à falta de cultura e de conhecimento da população. De acordo com a conselheira, a história do país está estruturada em uma cultura da omissão e obediência da população que desiste de questionar e participar. Renata faz um breve relato histórico para explicar a baixa participação na política brasileira:

Pela falta de cultura, pela falta de conhecimento, por achar que nós temos que ser mandados. Desde que os portugueses chegaram aqui, a gente sempre foi mandado. Os índios foram dominados, depois, foram os negros dominados e assim foi. Aí surge um branco que quer fazer uma raça ariana. Então, a gente sempre foi omissa, omissa, omissa, omissa: 'Deixa, eu estou comendo, eu estou bebendo, eu estou pagando as minhas contas, para mim está bom'. E não está bom, a gente pode ser melhor do que isso, ter conhecimento, não há o que pague isso na vida da gente.

O único obstáculo inicial à participação observado por Renata foi o desconhecimento, tanto por parte da comunidade em geral quanto pela comunidade escolar, da importância do espaço do Conselho Gestor: "Então, eu não sabia. Então, foi uma falta de conhecimento e informação minha em relação a isso".

A partir do momento em que Renata tomou conhecimento do colegiado, iniciou seu envolvimento, participando das festas da comunidade escolar e outras atividades. Segundo ela, as divulgações das reuniões e convites ao colegiado têm sido crescentes por intermédio da ampliação de contatos feita pela gestão e mobilização dos coordenadores nos grupos de atividades físicas. Mesmo com a adoção dessa estratégia da gestão, Renata considera que a divulgação pode ser ampliada, pois os encontros do Conselho não são informados nas reuniões dos pais dos alunos que estudam no Centro Educacional: "Então, eu vejo que esse ano houve mais divulgações, mas ainda não é o patamar que precisa". O aumento da rotatividade entre os participantes do fórum foi lembrado pela atual gestora como um indicativo de mudança em curso, embora a gestora não tenha feito menção, na conversa, ao parágrafo 9, do artigo 36 do Decreto $n^{\circ} 57.478 / 16$, que trata da consequência da ausência dos membros por mais de duas reuniões seguidas, sem justificativas, com destituição do cargo em favor da/o suplente. A atual gestão afirma ser necessária uma participação, de fato, e de não meramente de direito. Observa um aumento da participação das unidades escolares de novas pessoas, além das existentes. 
A conselheira Mercedes nega existir união na comunidade do CEU, e justifica o desconhecimento e o sentimento do medo como impedimentos para atuação:

Não, porque o povo tem medo. O povo não tem também o conhecimento, 'fia', Sabe? Se eu chego com um vizinho meu e falo, gente, nós podemos, nós temos esse direito, o CEU é nosso. Como usuário. Nós que pagamos pelo CEU. Nós podemos. Mas as pessoas não. Se limitam. Entendeu?

Embora atribua ao desconhecimento e ao medo como principal justificativa da falta de participação, Mercedes também considera a necessidade da introdução de uma estratégia de ação junto à gestão do CEU. Há a necessidade de se manter algum nível de diálogo com a atual gestão do CEU para o acesso de informações:

Eu também não posso, é, ficar sempre assim batendo de frente muito com a gestão, porque eles precisam de mim, eu também preciso deles. Porque, através dela, a gente tem acesso às coisas, mas se ela bloqueia esses acessos, eu vou direto na fonte. É o que eu falei para ela, convém você andar de mão dada comigo, do que querer. Porque ela é uma pessoa, assim: como pessoa, ela é muito legal, mas ela é meio que nem eu, ela fala as coisas na lata e na cara. E eu também. Entendeu? Então só que aí ela pode até falar e tudo o mais o que ela acha que ela pensa, assim como eu; me respeitando.

Há um acordo subentendido entre Mercedes e a gestão como subterfúgio e estratégia de ação: "É o que eu falei para ela, convém você andar de mão dada comigo."

Percebi que para Mercedes o abuso de poder é o principal obstáculo existente no Conselho Gestor. O estopim da reclamação contra gestão anterior do CEU teve início quando um funcionário terceirizado foi afastado de suas funções por motivação pessoal, adjetivada por Mercedes como "birrinha":

Chegou uma época aqui que a gente se mobilizou para tirar o gestor. Porque muitas coisas a gente via como abuso. Eu mesma falei, abuso de poder; esse aqui está querendo. Entendeu, ele bateu de frente e ele achava que, por ele ser gestor, ele podia tudo. Eu cheguei a falar com ele, falei, "olha, Fulano, eu nunca", com a gestora também.

O trecho a seguir mostra a preocupação de Mercedes com sua reputação, sendo esse o fundamento do prestígio, o que pode atingir sua imagem, abrindo a possibilidade de ser classificada como uma má pessoa (FONSECA, 2004, p. 43), quando é acusada pela própria gestão do CEU de ter dito palavras que alega não terem sido proferidas:

Entendeu? Eles falam, "Ah, mas foi a Dona Mercedes que falou... que deu essa ideia". Coisas absurdas que eu batalho contra... Eles chegam a fazer isso. 
Alega preocupação de estar sempre acompanhada de uma testemunha durante as conversas a gestão: "Eu nunca falo sozinha, eu sempre venho com alguém junto falar com eles; porque você fala aqui. Eles te jogam perante os outros."

Outro caso de abuso de poder ocorrido no CEU, relatado por Mercedes, foi o afastamento do ex-coordenador de esportes do cargo, anos atrás, devido à problema de saúde e idade avançada. O ex-funcionário afastado era frequentemente hostilizado pelos funcionários em exercício do cargo, sendo por eles tachado de "encostado", já que possuía debilidade física devido a problemas de saúde, conforme a dona de casa. Mesmo com a crítica do quadro de pessoal do CEU, Mercedes relata a vivência que teve com o exfuncionário antes do afastamento, quando frequentava as aulas esportivas:

E mesmo ele, como diziam os funcionários aqui, que ele era encostado, ele... ele fazia... sempre fez caminhada sete horas da manhã. Ele era o primeiro funcionário a chegar aqui. Ele saía da salinha, antes da gestão, ele saía... se arrastando; porque ele tinha vários, muitos problemas de saúde... pra fazer um alongamento com a gente aqui fora, pra gente começar a nossa caminhada; quando o professor se atrasava, coisas assim, acontecia de ele não vir, ele atendia. Muitas vezes ele não fazia com a gente porque ele não podia, mas ele falava. Todo dia! Ele não tinha necessidade de estar aqui.

Ela conta que aproximadamente quinze dias após o afastamento, o homem faleceu em um acidente de queda na escada em sua residência. Mercedes especula a possibilidade do impacto psicológico que o afastamento pôde ter causado na vida do ex-funcionário, o que teria levado ao acidente:

Mas até aí quanto ao lado financeiro, eu creio e tenho quase certeza que ele não tinha necessidade mesmo. Mas e o psicológico da pessoa? Entendeu? Uma semana, quinze dias depois que afastaram ele, ele morreu".

A morte do funcionário agravou a pressão junto à gestão, o que levou a comunidade a se unir em abaixo assinado, que contou com mais de cinco mil assinaturas. Esse reivindicava o afastamento do gestor do CEU, na ocasião, conforme relato de Mercedes.

Era um senhor muito legal. E através também disso... e 'foi' ocorrendo umas coisas... sabe? E... nós chegamos, eu cheguei a enfrentar de cara com o Marcos, por que que eles afastaram, ele e a Edilaine afastaram o Seu Angelo, sabe? Porque o Seu Angelo, ele chegava de manhã, eu conversava muito com ele, e ele era muito, assim hostilizado... ele era muito...

De acordo com Mercedes, a hostilização sofrida pelo ex-funcionário também se devia à sua elevada faixa etária, agravada por problemas de saúde. Segundo a entrevistada, assim como ela sentia a diferença no tratamento que as pessoas na sociedade fazem pela 
sua cor negra da pele, ela compreendia a "hostilização" contra o ex-funcionário devido à idade. Chega a mencionar os pais idosos, para explicar a situação:

É assim, porque, que nem: meus pais, meus pais, hoje... ontem minha mãe completou 88 anos de idade... e a gente, quer ou não, gente, eu sempre... Eu sou negra. Então, aqui, eu não sou hipócrita de falar que eu nunca passei por... sabe? E até hoje eu passo. Eu sei que é crime e é tudo o mais, mas tem gente que não suporta negro, tem gente que não suporta pessoas de idade...

E completa: "Sabe? Quando você chega numa idade, é porque é velho, que tem problema de saúde, tem que ser encostado, jogado". Como mulher negra, relata o preconceito sofrido:

Preconceitos. É, eu não falo, mas você sente! Daí, a partir disso, eu tento bater de frente com a pessoa, mas assim, alertar. Eu não vou chegar a ir para uma delegacia.

Diante das evidências do preconceito sofrido, Mercedes diz que oferece sempre uma oportunidade para que a pessoa possa refletir:

Mas porque aí dá tempo de a pessoa pensar um pouco e ver que ela é igual a mim. E eu sempre bato na mesma tecla: gente, eu não sou melhor que ninguém. Todos nós, pelo contrário, não têm ninguém igual, todos somos diferentes; mas na realidade... na realidade nós somos todos iguais com as nossas diferenças, mas, é... nós temos que tentar viver no mesmo espaço, no mesmo mundo; a gente pode ter pensamento diferente, atitudes diferentes.

Em conversa com a atual gestora, um dos obstáculos encontrados quando assumiu o equipamento educacional se relacionava à predominância do público idoso nas dependências nas atividades ofertadas no CEU. Atribui à carência de políticas públicas e de orçamento direcionado à população de idade mais avançada pela Secretaria Municipal de Educação. Ela não faz críticas às pessoas que passaram pela gestão do CEU antes de ocupar o cargo. Fala do respeito por todos os que já ocuparam a função e limita-se a dizer do engessamento do CEU na pasta da Educação, que sem investimento predial, de materiais e de pessoal, mostra que inexiste uma política oficial de uma secretaria que assuma as responsabilidades do equipamento educacional unificado. Dessa forma, ninguém sabe qual secretaria o CEU pertence. Entende que cada Centro Educacional possui suas respectivas demandas e necessidades. No referido CEU, existe um público alto de idosos a ser atendido, e falta de investimentos da Secretaria Municipal de Educação para os profissionais que trabalham com esse público de maior faixa etária. 
Já Mercedes também faz o enfrentamento e cobrança diante da falta de transparência e de informação da gestão. Ela reivindica o acesso aos fatos que ocorrem no equipamento e a informação, sob ameaça de acionar instância superior municipal:

Entendeu? Quando surgiam problemas e tudo mais, e eles sabem que eu faço mesmo. Que eu sou completamente contra, não quero questionar, [ou] coisa, mas coisas assim, fundamentais e sérias. Se eu quero, se eles não querem abrir, ou me dar o conhecimento ou me deixar a par das coisas, ou ficam me omitindo, eu fico sabendo as coisas e eu venho questionar e coisa assim, se eles não 'sentar' e abrir comigo o que 'tá' acontecendo, coisas assim, eu ligo direto pra Diretoria Regional de Ensino. Na gestão do Marcos e da Edilaine eu consegui trazer o... na época o diretor regional, o Francisco, o Seu Francisco, umas cinco vezes aqui para se reunir comigo e com alguns moradores.

Observa a falta de registro em atas das reuniões, o que pode dar margem para a atribuição de outras interpretações. Relembra que na gestão passada, a atas das reuniões anteriores eram relidas entre os presentes, tanto que muitas vezes chegava a se recusar a assinar, pois o registro não dizia respeito ao seu entendimento em reunião:

Sempre uma reunião anterior eles liam a ata, a gente assinava, quem estava, e para... Tanto que várias vezes eu me recusava a assinar, porque eu achava que não foi muito bem aquilo.

Para relembrar a discussão do mês anterior registrada em ata, muitas vezes, o debate era retomado: "Não me recordo. Para se recordar, começava a debater de novo, daí, daí, 'ah, agora eu assino"”.

Mercedes reclama de possíveis abusos da antiga gestão do CEU, ciente da força e do papel da comunidade. Assim como a conselheira Nair, acredita que a resolução dos conflitos deve passar pela participação coletiva:

Para questionar procedimentos do Marcos. E eu falava mesmo. Falava, gente, aqui não é a casa dele, ele está sendo pago para ser gestor. Então, eu sempre soube que se a comunidade. O problema é que eu sozinha não consigo fazer nada. E é o que eu sempre falei para as pessoas; eu falei, gente, se a gente se reunir, nós somos praticamente os donos, mas nós temos mais autonomia que qualquer funcionário ou a gestora.

Mariana avalia as gestões comandadas por homens e mulheres, em razão de já ter vivenciado os dois perfis ao longo de seu envolvimento no CEU. Conta que quando entrou no CEU, a gestão era feita por uma mulher. Por essa razão, acredita que seja mais fácil estabelecer contato e diálogo com mulheres à frente do Centro Educacional. A conselheira relata que assim que a atual gestora chegou para trabalhar no CEU, foi bem acolhida pela comunidade: 
Quando ela chegou aqui, a gente procurou acolher ela bem acolhida sabe? Eu acho assim, que se você chega, e você não é bem acolhida, você não tem como você se chegar, você fica sempre insegura. Eu penso assim. E se você chega num lugar você é bem recebida, bem acolhida, você vem hoje, amanhã você vem também, então começa-se a se fazer outro ambiente. E não era o caso também, o rapaz que tinha aqui ele não era assim uma pessoa de se misturar. Ele saia as reuniões sem ter o que falar. A gente ia nos lugares, eu vinha aqui ficava mais ele, mas não tinha muito assunto. $\mathrm{O}$ assunto dele era muito curto. Não tinha assim, um assunto para conversar, chegava uma hora que não tinha nenhuma conversa. Nenhuma história para contar, ele não tinha.

Mariana avalia como positiva sua relação com o antigo gestor, mesmo que sua preferência fosse por mulheres à frente da gestão e ele tivesse um perfil reservado. A relação com o antigo gestor também teve avaliação positiva, já que, frequentemente, Mariana recebia de sua parte permissão para montar barraca nos festivais do CEU e convites para participar de atividades externas:

Mesmo assim, dele não ter esses assuntos, eu não critico ele porque acho que era o jeito dele, e não sei. Mas ele nunca me deixou assim de fora para dizer essas coisas que tinha, ele sempre me convidava, Mariana você vai colocar essa barraca, quer colocar, eu sempre coloquei a minha barraca. Ele nunca me deixou de fora.

Uma hipótese aventada por Mariana que justifique a falta de comunicação do antigo gestor, além de sua personalidade mais reservada, era a frequente ausência dele no CEU, pois lecionava em outra instituição.

A discussão sobre a cessão de espaço e posse das barracas para a comercialização dos produtos durante as principais festividades no CEU foi um tema que apareceu em mais de uma entrevistada. Como de praxe, os moradores costumam montar suas barracas e comercializar produtos durante as principais festividades no Centro Educacional, ao longo do ano, sendo uma oportunidade para a comunidade local vender seus produtos, por isso a acirrada disputa de conquista de um espaço.

O que causou indignação de Mercedes foi quando a moradora Cynara recebeu permissão da gestão do CEU para vender seus produtos, em 2018, monopolizando praticamente as vendas no Centro Educacional. Mercedes alega que Cynara foi selecionada pela gestão pela experiência de se especializar, trabalhar e ser conhecida no ramo de festas infantis na região. Entretanto, essa escolha gerou revolta em Mercedes, que defendia condições iguais na ocupação do espaço, para o trabalho e geração de renda: "uma oportunidade legal para os comerciantes da região ou para quem trabalha, como a dona de casa que vende cachorro-quente de ganhar uma graninha". 
Pelo relato de Mercedes, a adoção de novas regras na cessão do espaço feita pela atual gestão contrariou os moradores que participaram dos anos anteriores. Pela nova normativa, a gestão decide pela centralização em uma única pessoa a comercialização de produtos oferecidos nos eventos, com a justificativa do/a morador/a deter a expertise. Entretanto, a conselheira questiona a falta de oportunidade dada à comunidade para participar de forma igualitária do evento. O critério da qualidade do produto comercializado, segundo Mercedes, não precisa ser excludente, gerando uma oportunidade para a melhora da qualidade do produto nas festividades seguintes: "a gente pede qualidade, mas se não tiver o outro ano, vai melhorar e pronto, ninguém vai poder barrar".

Conforme deliberação em Conselho, o percentual revertido e destinado ao Centro Educacional municipal é de $20 \%$ do arrecadado. A indignação de Mercedes aumenta quando a gestão também dá oportunidade ao filho de Cynara, de cantar em evento:

A gestora vira na reunião e fala assim: "o grupo do filho da Cynara vai tocar e como uma mão lava a outra, então..." Porque o grupo do filho dela vai tocar, ela tem o direito de montar uma barraca e vender? Eu fiquei muito puta, amigo! Daí eu ainda falei, sabe por que eu bato de frente com a gestora, então, para não criar clima, eu virei e falei assim, "Quero ver na próxima, eu vou querer uma barraca de refrigerante, uma de churrasco, uma de..."

O depoimento de Renata também faz crítica ao favorecimento de parente de funcionário do $\mathrm{CEU}$ para tocar no show promovido pelo equipamento educacional. Em reunião do colegiado, assim que uma das conselheiras presentes observa o descumprimento de regra do equipamento educacional, ocorre a "troca de farpas" e intrigas que, posteriormente, é levado para o campo pessoal entre a representação do CEU que participara da reunião e a conselheira que acusou um terceiro de favorecimento.

A indignação de Mercedes se deu também quando a funcionária do Centro de Educação Infantil (CEI) do CEU, em vez de defender oportunidades iguais a todos os participantes, saiu em defesa de Cynara:

Daí uma das representantes do CEI virou e falou assim, "É, desde que tenha qualidade"; eu falei, gente, a Cynara trabalha com isso, a Cynara trabalha com festas, eu conheço a Cynara, há muito mais tempo que todo mundo aqui. Eu não estou questionando a qualidade, eu estou questionando o direito dela: é um direito que ela tem, é um direito que eu tenho. Nós somos iguais.

Além da revolta diante do monopólio da comercialização de produtos no festival, Mercedes reclama da mudança da nova gestão em centralizar a renda obtida com a venda de produtos de todas as barracas na Festa da Cultura Popular Brasileira. Assim como nas 
festas dos anos anteriores, a renda arrecadada com a venda de bolos era revertida para a compra de produtos e acessórios para as aulas de ginástica, frequentadas pelas mulheres que doavam os bolos para a comercialização.

A atual gestora comenta que assim que assumiu o Centro Educacional, em 29 de março de 2017, encontrou resistência das mulheres participantes do Conselho, que fizeram campanha para que não houvesse doação de bolos para a barraca do núcleo de esportes, em retaliação às mudanças propostas pela gestão, que naquele momento acabava de assumir.

A reclamação de Mercedes dizia que a nova gestão, ao implantar a política de caixa único prejudicaria as/os usuárias/os do núcleo de esporte, que deixariam de ter retorno na melhoria de produtos de ginástica, como halteres e colchonetes, com a venda dos bolos. De acordo com Mercedes, alguns materiais de ginástica recebidos pela Prefeitura não seriam de interesse, pois eram subutilizados em aula, e por isso o esforço em manter a barraca para que o grupo de mulheres pudesse ter autonomia na compra dos produtos realmente necessários. Para Mercedes, a barraca de bolo é a que mais arrecadava dinheiro nas festas promovidas pelo CEU, porque os alunos de esportes são adultos e em maior número.

O tema da partilha e controle da distribuição de barracas, tanto na Virada Cultural, quanto na Festa da Cultura Popular Brasileira, que costumam ocorrer em maio, foi pauta de uma das reuniões no Conselho Gestor. Segundo Mercedes, houve questionamentos no Conselho em relação à programação da Virada Cultural e da Festa da Cultura Popular Brasileira. O primeiro evento teve sua programação estabelecida de "cima para baixo", enquanto a Festa da Cultura teve a divisão de barracas concentrada em uma única vendedora:

E eu já vi mesmo, 'fia', ano aqui, em quermesse, a Cynara, quando trabalhava com isso, ela conseguiu barraca de pastel, de algodão-doce, de cachorro-quente, de batata frita. E vamos dizer ela estava com a família; ela põe: uma barraca para o filho, uma para o marido, uma para ela...

Conforme relato de Mercedes, não houve a deliberação em Conselho Gestor da programação da Virada Cultural do CEU em 2018. O evento promovido pela Prefeitura Municipal de São Paulo que, costumeiramente, acontece nos meses de maio, teve toda sua programação decidida e encaminhada ao Centro Educacional. Assim como a decisão de concentração das barracas em uma única fornecedora, a pauta da programação da Virada não teve espaço de discussão no Conselho Gestor. Por esse motivo, Mercedes questionou a função do colegiado e percebeu que sua indagação foi percebida pela gestão do CEU:

Veio a programação inteirinha da Virada Cultural pronta, veio quem iria vender pronto, quem iria se apresentar pronto, quem iria vender pronto. 
O Conselho diz que não teve participação nenhuma. A gestora e eles fizeram essa última reunião. E é o que eu vou falar: Conselho Gestor para quê? Só que ela percebeu que eu fiquei meio assim. Eu percebo, porque eu conheço as pessoas; só que eu fiquei quieta, não falei nada, e nem vou falar.

Mercedes fala da relação hierárquica do CEU com a Secretaria Municipal. Observa que em edições anteriores da Virada Cultural, o Conselho Gestor teve "participação constante, principalmente a comunidade, de escolher temas". Inclusive, na parte alimentícia, toda a comunidade tinha a "oportunidade de vender pastel, cachorro-quente, tapioca, queijo" e não uma única pessoa, como foi feita na edição do ano de 2018.

É tipo assim, o que eu também não quero, Cristiane, é assim... Que nas próximas festas, ou alguma oportunidade que tem alguém de vender, que aquela pessoa falar, "não, a vaga é minha porque eu faço, é minha porque eu consigo, é minha porque eu já tenho, eu já faço, ela deixou..." Não se sentir dona. Não é dela! Você está entendendo?

Segundo Mercedes, desde a última reunião do Conselho, no segundo trimestre de 2018, houve um rompimento mais acentuado dos "laços de comunidade e gestão", principalmente porque a agenda da Virada Cultural não foi debatida previamente no Conselho Gestor, como outrora. Em segundo lugar, foi dada preferência para uma única pessoa a oportunidade de produção e venda de produtos alimentícios para o evento no CEU, o que gerou até uma intriga pessoal com a gestora, conforme já relatado.

O depoimento a seguir de Mercedes revela a disputa em torno da legitimidade da fala do Conselho versus da gestão do CEU. À medida que a conselheira percebe o engessamento propositivo da programação do evento, ela desiste de questionar no espaço do colegiado. É interessante a natureza da desavença e como se desenvolve o controle de poder do espaço que ultrapassa os limites do muro do Centro Educacional.

Então quer dizer, eu já senti, sinceramente, nessa última reunião, que os laços de comunidade e gestão já não estão mais rolando. Primeiro porque veio tudo pronto. Eu não questionei muito ali porque ia ficar um negócio chato e realmente, tanto que eu ainda falei, gente, não é a pessoa, eu sou amiga da Cynara; mas você sabe que tem gente que pensa mesmo... E eu creio que até já chegou ao ouvido da Cynara, que eu quis que a Cynara...

Renata também chega a falar da existência de uma "hierarquia muito grande" dentro do Conselho. Essa hierarquia ocorre quando o Conselho é consultado sobre demandas que não são deliberadas no Conselho. Nessas ocasiões, a conselheira afirma que é necessário ser irredutível quando a direção vem “com algumas coisas já prontas, mastigadas e só você tem que assinar e concordar e é isso, é isso e pronto." 
Assim que assumiu a atual gestão do CEU e do Conselho Gestor, em 2017, a atual gestora utilizou-se do Decreto $\mathrm{n}^{\mathrm{o}} 57.478 / 16$ para tomar conhecimento da comunidade. Importante que a gestão destaca que as pautas do Conselho eram originadas da própria comunidade, fato que foi contestado por Mercedes e Renata, que afirmam que as demandas das pautas das reuniões partem do poder público para a população e não ao contrário. Percebemos um discurso entre o poder público e a associação de mulheres que não é posto em prática. Devemos considerar que embora o período analisado da pesquisa seja de 2014 a 2016, os relatos das participantes podem extrapolar a esse período.

A atual gestora notificou que tomou à frente e manteve a formação do Conselho Gestor quando assumiu o cargo, porque precisava conhecer a comunidade. Foi por meio do Conselho que foi feito esse primeiro contato, com a finalidade de saber quais as demandas e as necessidades da comunidade. A atual gestora afirma que o Conselho é o canal por onde a comunidade tem voz ativa e por isso foi se apropriando da participação e do espaço. A atual gestão do CEU, que assumiu em março de 2017, a direção do equipamento educacional, destaca que mesmo sendo possível a troca dos membros do colegiado, por conta de normativa publicada ao final de 2016, pelo Executivo Municipal, decide pela manutenção do Conselho Gestor do CEU, formado em fevereiro daquele ano, para não deslegitimar a organização que havia se formado. Segundo ela, mesmo existindo a possibilidade da realização da troca dos membros do Conselho, em razão do Decreto $\mathrm{n}^{\mathrm{o}}$ 57.478/2016, que estabelece que a periodicidade do Conselho deixa de ser anual para ser bienal, ela resolve manter a formação do colegiado para não desprezar e afrontar o Conselho que já havia se constituído em fevereiro de 2016. Somente no ano de 2018 é que foi realizada nova eleição na instância participativa do CEU, conforme normativa de 2016.

Já Mercedes pretende tratar com a gestora do CEU em espaço coletivo, na presença de testemunhas, para que não exista a possibilidade de invenção de fatos que possam comprometê-la:

Que eu sei como é que funciona o negócio. Mas isso eu vou resolver com a Sara, mas na reunião, porque eu não vou também nunca mais falar nada sozinha com ela. Eu falei para a Renata no sábado; eu quero sempre ter alguém do lado. Porque esse negócio de manipular, de trocar as palavras. Eu falei, gente, 'ó', eu não preciso de mentir. Se eu tiver que falar na sua cara eu vou falar. Você está entendendo? Agora, colocar coisas ou entender o outro lado porque você pode entender várias coisas; do que eu falei. Gente, distorcer o que eu falei é diferente, e não vem querer me colocar em uma fria não. 
Mercedes destaca que os acordos e conversas paralelas estabelecidos nos corredores do CEU, e não no espaço do Conselho Gestor, podem dar margem a questionamentos sobre a legitimidade da demanda no colegiado. Como esse tipo de conversa é feito em local sem testemunhas (ou outros membros do colegiado), a legitimidade da demanda pode ser questionada já que pode visar a interesses individuais e não coletivos.

Embora Mercedes afirme procurar fazer as conversas e tratativas no espaço do Conselho, percebi que existe uma preocupação da conselheira de como os outros participantes irão compreender a origem da demanda. Até porque a participação no Conselho é entendida como participação no CEU e vice-versa, ou seja, os espaços se misturam. Se for feita em conversa particular, pode levar a entender que o caráter de sua reivindicação seja individual e não coletivo: "Daí, às vezes, muitas vezes falam: nossa, “mas quem é tudo isso, está querendo isso?". Tipo, é você que quer e você vem dizendo que querem. Você está entendendo? E não é assim."

Recorrentemente, em sua fala de teor reclamatório, Mercedes reivindica a necessidade do respeito no trato com o próximo. Quando discorre sobre a tensão com a gestão, Mercedes chama atenção para a reciprocidade do respeito: "Porque eu respeito ela como pessoa e como gestora, mas ela também tem que me respeitar”. Para ela, a posse de um diploma não autoriza o desrespeito. Percebi uma repetição do discurso e uma reivindicação de reconhecimento, respeito e cidadania, seja por aqueles com ensino superior ou não, em um local nitidamente educacional. E essa reivindicação passa, necessariamente, pela importância de ouvir, ser ouvido/a e da importância de não ignorar os canais democráticos existentes no equipamento educacional, reivindicado pela conselheira à gestão:

Porque é assim; e vivo falando, gente, não é porque as pessoas têm diploma, que é formada, que é pedagogo ou coisa assim, que é mais que eu, não. Entendeu? Eu acho que se as pessoas se respeitarem, tudo bem, porque, também, é... você ter um diploma não quer dizer que você tem mais educação que eu.

\subsubsection{A gente tinha muita coisa aqui}

No conjunto de depoimentos que remontam a avaliação das gestões do CEU, não há nenhum relato das entrevistadas que discorde da ideia de que as gestões anteriores foram melhores dos que as atuais. Tanto Mariana, quanto Lilian, ambas com mais tempo de participação no Conselho dentre as entrevistadas, concordam que anteriormente no CEU havia mais acolhimento e maior oferta de serviços à população. Elas mencionam que 
durante o tempo de existência do Centro Educacional, a proposta original de uma gama maior de serviços prestados foi reduzida.

A conselheira Lilian associa a trajetória decrescente do Conselho Gestor com a queda de serviços CEU oferecidos à população:

Aqui a gente tinha muito passeios, a gente tinha muita coisa aqui, cursos, tem umas máquinas aqui de costura que nunca foram usadas. E a intenção da Marta era, a pessoa vem aqui, acho que tem cinco máquinas de costura industrial e nunca foram usadas. Então essas máquinas eram para $\mathrm{o}$ pessoal aprender a trabalhar para procurar serviço. A ideia dela era muito boa, mas não foi para frente, infelizmente. A panificação era para o pessoal aprender a fazer seu pão e vender, era para a pessoa trabalhar, que o negócio é assim, o importante é você ensinar a pessoa a pescar, e acho que a intenção dela era essa.

Inicialmente, o Centro Educacional oferecia oportunidades à população local como passeios e cursos com a utilização do maquinário instalado, segundo Lilian. Ela chama atenção, repetindo duas vezes o trecho de que o maquinário "nunca foi utilizado". Seu relato remonta à proposta original do $\mathrm{CEU}$, que previa cursos de qualificação profissional de panificação à comunidade. $\mathrm{Na}$ atualidade, o CEU não tem nenhum projeto similar em funcionamento que a conselheira pudesse mencionar, comprovando sua reclamação.

A entrevistada Lilian também fala que a gestão no passado oferecia uma gama de opções culturais de passeios para outras localidades:

A gente tinha passeios, a gente tinha muita coisa legal aqui sabe. Mas aí cada um que entra é pior que o outro, esse então Deus que me perdoe, é uma lástima sabe, eu não tenho vontade, imagina, entrar para a política para me estressar, para me aborrecer?

Antes de mais nada, segundo Lilian, a mudança de gestão acarretou uma piora do quadro das administrações municipais, ao longo dos anos, deixando a entender que essa piora está relacionada à atuação negativa de representação na política parlamentar.

Conforme tratado no capítulo anterior com detalhes, Mariana foi a única entrevistada que relatou experiência mais significativa em sua vida de participação política partidária. Ao contrário das outras ouvidas, ela compreende ser parte da política os fracassos, no seguinte trecho: "isso vai de política", sem deixar de criticar as gestões mais recentes:

Olha, teve umas coisas que teve um fracasso, que isso vai de política, então no ano que eu entrei, que era bem diferente, era bem melhor, as coisas eram assim, mais acolhido, não sei como eu posso explicar, mas era bem diferente. Quando trocou, quando entrou o Kassab prefeito, aí fracassou, o Conselho ficou fraco, não teve mais aquela garra para o que tinha que fazer, ficou abandonado, no português correto. Agora o 
Conselho está se levantando de novo. Do ano passado para cá teve uma diferença bem grande. (Mariana)

A entrada de Mariana no CEU ocorreu no ano de 2009, quando o prefeito Gilberto Kassab (DEM) era prefeito. Kassab foi prefeito de São Paulo por duas vezes entre os anos de 2006 e 2012. A primeira vez, assumiu a prefeitura quando o titular José Serra renunciou, após governar entre janeiro de 2005 a 31 de março de 2006. A segunda vez foi quando foi reeleito no pleito de 2009. Mesmo que ela não tenha participado do Conselho nas gestões anteriores de 2009, avalia o fracasso do colegiado na era Kassab, classificando o período como de abandono da gestão municipal aos CEUs. Mesmo que no início do trecho tenha destacado que o Conselho antigamente "era bem diferente, era bem melhor", ao final do seu depoimento lembra que o Conselho tem se reerguido e se recuperado. Mariana associa ao período antigo do Conselho com o acolhimento que inexiste na gestão atual: "mas era diferente".

Lilian remonta à ex-prefeita Marta, para lembrar que foi durante sua gestão que os CEUs foram criados. A dona de casa também lamenta a derrota da ex-prefeita nas urnas, no escrutínio de 2008:

Olha, eu acho que cada um que está entrando lá é um pior que o outro, vai piorando. Aqui já foi muito bom. Foi muito bom aqui, quem, essa ideia do CEU é da Marta, ela fez. Eu fiquei muito triste quando ela perdeu, sabe, acho que uma pessoa que eu seguiria era a Marta, mas aí já vi que ela partiu para o outro lado lá. Falei também não tem meu voto não. Sabe, e cada um foi pior que o outro.

Quando indagada, na sequência, sobre o que achava das pessoas que participavam da política, tanto no Conselho Gestor como fora desse espaço institucional, Lilian associa à degradação política com a infidelidade partidária, quando da mudança de partido feita pela ex-prefeita Marta (PT). Segundo o relato da conselheira, a falta de fidelidade partidária da ex-prefeita é sinônimo da ausência de compromisso com os princípios do partido e junto ao eleitorado, pela qual Lilian era simpatizante, ainda antes da filiação de Marta ao MDB, entre 2015 a 2018. Em 2000, Marta Suplicy (PT) foi eleita prefeita de São Paulo, em disputa com Paulo Maluf. Em 2007, ela assumiu o Ministério do Turismo, pelo governo do presidente Lula (PT) e, em 2010, foi eleita senadora, afastando-se para ocupar o cargo de Ministra da Cultura, no período de 2012 a 2014, quando saiu do PT, para disputar a prefeitura de São Paulo, sem sucesso. Em 2018, integrou o MDB e se desfiliou do partido, aposentando-se da vida política.

\subsubsection{Sou usuária, sou da comunidade e eu sou fiscal do povo mesmo}


De um modo geral, quando as entrevistadas criticaram as gestões dos CEUs, as falas concentraram-se na gestão atual. Muitas razões foram apontadas para justificar as críticas a quem ocupa o espaço de administração do Centro Educacional. Dentre os depoimentos que serão analisados a partir de então, a crítica predominante foi a reivindicação por fiscalização, tanto na condução da política pública quanto no que se refere ao cumprimento de jornada dos servidores públicos, especialmente.

Predominantemente, as críticas às gestões partiram de Mercedes. Existe uma preocupação da usuária em poder acessar às aulas com mais frequência do que seria permitido. Aqui, Mercedes faz uma distinção entre duas gestões: a mais antiga, onde era permitido quantidade ilimitada de inscritos nas atividades esportivas, ao passo que a gestão mais recente passou a instituir limitações nas regras de inscrição. Importante frisar que a restrição nas inscrições não foi instituída pela atual gestora, mas anteriormente, conforme Mercedes menciona, em 2015. Embora o critério não vigorasse mais em 2018, na ocasião da entrevista, o regulamento tinha a função de limitar a participação nos cursos para além da quantidade permitida:

Porque é assim: começaram a limitar, há três anos. Na gestão da Edilaine e do Marcos liberaram. Desde que você compra (sic), porque, se eu me inscrevo numa atividade, eu não vou me inscrever para ficar dizendo que eu faço, que eu não faço...

Durante a entrevista, em 2018, Mercedes diz frequentar outras modalidades na área de esportes, mesmo sem estar matriculada, e questiona o estabelecimento de critérios: "Para que isso? E eu cumpria. Era liberado, três, cinco... Eu fazia cinco atividades brincando.”

Com a cessação do critério de participação na área esportiva do CEU, Mercedes conta que passou a frequentar o Centro Educacional praticamente todos os dias, com atividades intercaladas. Às segundas, quartas e sextas-feiras frequenta o CEU para as atividades de caminhada; às terças e quintas-feiras de manhã faz Tae kwon do e de noite realiza alongamento; e aos sábados, frequenta as aulas de Zumba:

Tem um grupo de caminhada, segunda, quarta e sexta, professor Rodrigo. Eu não estou matriculada nessas aulas, mas venho; há dois anos eu não estou e há dois anos eu faço.

Mercedes faz o relato de uma série de problemas ocorridos em 2017, na ocasião da apresentação, no auditório do Centro Educacional, feita pela companhia de comédia de stand-up Risadaria.

Ano passado aconteceu uma coisa muito chata aqui, que eu bati de frente com essa gestora, que ela estava nova aqui, que foi a... eu digo já uma 
droga porque, gente, a produção dessa Risadaria, a Prefeitura deve ter gasto horrores pra contratar esse povo, mas é péssima.

A escolha da companhia teatral, além de não ter passado pela deliberação do colegiado, também infringiu uma resolução do Conselho ao possibilitar que a produção garantisse a reserva de acentos em espaço público do auditório no dia da apresentação, como também teve alto custo pago pela prefeitura, segundo Mercedes. Em sua visão, o Conselho foi ignorado tanto por não ter sido consultado da escolha da companhia teatral, como também foi desconsiderada determinação anterior tomada no Conselho Gestor, que proibia que alguém tivesse preferência de acesso ao espaço do CEU nas apresentações:

Eles chegam e tomam tudo! E fizeram um contrato com a diretoria regional, uma coisa assim, que depois leram pra mim; depois, que eu não sabia, que abriram mão de tudo, eles, a produção dessa Risadaria, que tinha o domínio de tudo, sendo que, há anos, em reunião de Conselho Gestor foi colocado que peças de teatro e tudo o mais, ninguém teria preferência de nada, não poderiam ser distribuídos ingressos antes pra ninguém; ninguém tem o direito de entrar antes de ninguém, nem funcionário, nem, nem de produção, nem o raio. Pode vir o Papa, não poderia. Isso eu assinei também, consta no livro de ata. Nesse dia, o ano passado, nesse passaram por cima de tudo. Nossa, eu fiquei louca!

E durante seu relato crítico, Mercedes chama atenção para outra forma de participação entre a comunidade e o CEU e que ainda não havia aparecido na pesquisa: a virtual: "Eu e muita gente, houve reclamações na página aqui do CEU na internet; eu fiquei doida! Porque eu falei, gente, para quê, se existe um Conselho Gestor?"

Chama atenção para a responsabilidade da gestão diante da situação e destaca a importância do documento chancelado no colegiado:

Foi assinado, foi documentado... sabe? E eles abriram mão disso. Eu acho que antes deveriam ter chamado o responsável dessa produção desse show com o Conselho Gestor daqui ou alguém representando, mostrado o documento: "Nós não podemos fazer isso, por causa disso e disso e daquilo".

Irritada, ela relata que após o evento acessou à página na internet do CEU no Facebook com o intuito de criticar a gestão pela internet e percebeu que outras pessoas, assim como uma usuária do CEU também se indignara. Embora desconhecesse a simpatizante, alega ter curtido e comentado postagem no Facebook, reforçando com o convite para que ela participasse da reunião do Conselho, mas nunca obteve retorno daquele encaminhamento: "Eu estive ali no Facebook sempre, e durante uns três meses seguidos eu a convidei. Mas eu acho que esfriou e eu acho que ela falou, "ah, deixa para lá." 
Mercedes conta já ter feito convite de participação no Conselho Gestor para os participantes que frequentam a atividade física no prédio, sem sucesso. Uma usuária convidada alegou já ter participado tanto do Conselho, em gestões anteriores e havia desistido de participação porque "nunca resolveu nada". Por outro lado, a conselheira não concorda com a banal reclamação que despreze o colegiado: "começa a te irritar, porque a pessoa reclama, também não quer fazer nada para ajudar."

A fala a seguir identifica outros tipos de participação no Conselho Gestor, como a fiscalização e a denúncia feitas por integrantes do colegiado. As formas de participação não se limitam, meramente, à presença em reuniões mensais, embora predominem:

Mas daí vai ter um dia, 'fia', que eu vou vir, vou procurar e se ela não tiver, nossa, daí eu vou direto à fonte. E quantas vezes eu ligo e me identifico e falo, e denuncio mesmo, falo, "gente, eu sou usuária, sou da comunidade e eu sou fiscal do povo mesmo, de onde vai meu dinheiro. E no CEU está acontecendo isso, isso e isso, tem vários cargos lá, mas quando você vai procurar alguém do cargo não tem ninguém”. Os concursados estão. Que nem, tem a outra Sara, a moreninha, que não tem um dia que ela não falta, só não acha ela quando ela está de férias. $\mathrm{O}$ Osmar que atendeu o telefone quando eu liguei, que também é um funcionário exemplar, está direto aí, mas os coordenadores hoje em dia estão em falta.

Assim como Lilian, Mercedes não acredita haver dificuldades de atuação das mulheres no colegiado, mas falta de interesse das pessoas em geral: "E outra, as pessoas são assim, Cristiane: é muito melhor vir tudo na minha mão, mastigado, do que lutar por aquilo."

Mercedes, ao ser indagada sobre as razões que acredita serem necessárias para que as mulheres participem do Conselho Gestor, responde não se referindo ao colegiado do CEU, especificamente, mas entende a participação no Conselho como a participação no CEU, de um modo geral: "Então, mas daí cai nessas atividades. As pessoas reclamavam muito que final de semana não tinha nada aqui. Queremos aula de zumba, e até aula daqueles bastões. Pole dance?"

Ela também crítica a ausência da gestão e de outros funcionários no equipamento educacional quando acionados:

Eu liguei para cá umas três vezes atrás da gestora e ela não estava; isso no dia seguinte, porque eu já tinha visto depois da reunião que ela tinha ido embora. Pedi para falar com o coordenador do esporte, não tinha um, pedi para falar com a outra funcionária, ela não estava, tinha saído para uma reunião... não tinha ninguém. 
Quando tem alguma sugestão de ideia que acha ser de interesse do coletivo de mulheres do CEU, fora do espaço do Conselho, a dona de casa procura levar proposta para a revisão da decisão: "Nesse dia, que eu pensei nos refrigerantes, nessa ideia, que eu passei para a Renata, ela falou, "Mercedes, mas a gestora já decidiu em Conselho..."; falei, "mas é uma coisa que poderia se rever."”

Em alguns casos, Mercedes decide compartilhar sugestão de ideia até mesmo quando o tema já foi deliberado no colegiado. E reclama quando precisa acionar a gestão e não encontra os responsáveis pelo encaminhamento de sua demanda. A conselheira Mercedes critica a ausência da gestão, principalmente quando ela deveria “estar cumprindo horários e não cumpre." Percebi que a fiscalização da conselheira não se atém ao momento da reunião ou a grandes eventos cíclicos ocorridos no espaço. Mercedes conta que sua cobrança e fiscalização no cumprimento do horário de trabalho dos funcionários públicos do CEU ocorria desde as gestões anteriores.

Mas uma coisa que, ela iria bater de frente; porque esses negócios de reunião, eu já falei para ela. Falei, gente, a gente é fiscal de vocês. Eu tenho que ser direita, de vir e cobrar a presença de uma gestora, porque eu falei muito para o Marcos, isso. A Edilaine, eu ia direto. A Edilaine sempre viajando, não estava. Daí eu comecei a cobrar: falei, "tem gestor e não tem, vai começar toda a palhaçada de novo?"; falei, "Mas que que é isso? Vocês têm horário, vocês têm que cumprir!". Eu falei, poxa, mas você procura... coordenadores de esporte; que nem hoje, você vai procurar um coordenador de esporte aí, não tem um.

Indignada, Mercedes relata outro caso de descumprimento da jornada de trabalho dos funcionários. Certa vez, o filho da conselheira Renata foi retirado da piscina do CEU antes do término do expediente normal, com a alegação de que o docente responsável pela aula aquática tinha outro compromisso fora do Centro Educacional:

Não está sendo cumprido. A Renata mesmo, se ela conversar com você, porque ela disse que já veio reclamar do coordenador do esporte e do salva-vidas, porque tiraram o filho dela que estava usando a piscina. Tiraram o filho dela da piscina para fechar a piscina mais cedo, sendo que não pode. A partir do momento que tem temperatura da água, tem o horário definitivo de fechamento, pronto. Não adianta. O CEU tem horário para fechar, ele tem que ser fechado naquele horário.

Outra crítica endereçada à gestão diz respeito ao comodismo em ofertar atividades para a comunidade, mesma crítica de Lilian:

É que agora eles querem encher a bola e enganar o povo com esse negocinho de um mês, uma oficina aqui de dois finais de semana. Não é não? 
Além da necessidade de participar presencialmente no espaço do Conselho, com interações virtuais e a fisscalização dos funcionários, a atuação no CEU não se limita a reivindicar atividades, mas reclama a necessidade de uma agenda permanente de atividades, que não se limitem a esporádicos dias da semana.

\subsubsection{Mulher é que é boa para fiscalizar, para falar, para ter boca para falar}

As participantes entendem o espaço do Conselho Gestor e do CEU como um único local. Em muitos dos relatos, as conselheiras, ao se referirem ao fórum do Centro Educacional, também compreendem o espaço do CEU e até mesmo extrapolam o universo do equipamento, como observamos baixo, quando Nair reconhece a força das mulheres não somente do CEU, mas das moradoras da comunidade:

E olha que eu conheço algumas dessas mulheres. Eu andei muito por esses equipamentos e eu conheço a questão de como essas mulheres têm uma força, e sabem o que querem, sabem do seu papel, na comunidade, na sociedade.

Ao que tudo indica, quando Nair diz conhecer a existência de outras mulheres e reconhece as forças delas, ela entende as expectativas que a ex-conselheira depositava no grupo. Com propriedade, Nair afirma conhecer o vigor das mulheres pela experiência in loco, sua determinação e consciência de responsabilidade social. Já com o olhar no Conselho Gestor, Nair percebe o compromisso e força das mulheres, principalmente aquelas de idade mais elevada:

Tem várias aqui, tem umas cinco e seis, que é o mesmo pique da Mariana. Nossa, elas são mulheres para toda. Se você marcar. Só que você não pode atrasar, que elas ficam bravas.

Nair elogia Mariana, que a denomina de mulher "que tem boa vontade". E completa:

Ah, mas elas são muito sistemáticas. Mas a gente também aprende com elas. Elas são sistemáticas, ao ponto de você falar assim, se der 9:00 horas e não chegar, elas não vêm. Aconteceu alguma coisa. Porque elas são, assim, muito ponta firme; você conta, você podia contar com elas para... Eu conto com elas para qualquer coisa.

Algumas das razões observadas que expliquem essa associação das mulheres entre Conselho e CEU é que praticamente todas ocupam e participam de atividades para além do Conselho, ou seja, as mulheres enxergam participação no espaço do CEU porque estão inseridas em outras atividades que não somente no Conselho. Como elas estão inseridas nas atividades esportivas, culturais e educacionais, e se relacionam entre si nesses espaços, elas entendem que a participação não se limita ao Conselho, até porque algumas delas têm 
filhos/as e netos/as que estudam também no equipamento. Esse emaranhado de relações, de trocas e de diálogos nos diferentes espaços participativos do CEU garante legitimidade de tratar a participação no CEU, para além do colegiado. É por isso que Nair destaca a participação no CEU e no Conselho como ações articuladas e são entendidas como a mesma coisa:

Porque eu sei que você está falando do Conselho Gestor, mas eu vejo o CEU como um todo, com os professores, tudo, e eu senti muita dificuldade.

Durante toda entrevista da Nair, foi-me possível perceber recorrente relação das mulheres do Conselho Gestor com as mulheres que participam de outras atividades do CEU. Muitas vezes, quando a pergunta se dirigia especificamente às mulheres do Conselho Gestor, a resposta se referia às atividades esportivas ou da dança, como foi o caso do trecho a seguir, cuja pergunta a Nair refere-se ao Conselho Gestor:

Elas têm um trabalho. Depois, Cristiane, se você tiver tempo, eu quero mostrar para você: nós fizemos um trabalho aqui no CEU, nós até colocamos o nome, por isso mulheres.

A estratégia de aproximação adotada por Nair junto ao corpo docente da instituição educacional visava à apropriação de conhecimento, tomada de referências e contatos: "E o meu foco nunca foi falar com o pessoal mesmo do... mas era acessar os professores daqui, porque eu entendia que tudo tinha que começar por aqui".

Explicitamente Nair afirma que não tinha o objetivo de acessar e usufruir dos serviços do CEU, nas atividades esportivas, educacionais e culturais, como mera usuária, mas visava acessar ao conhecimento e ao contato dos/as professores/as. Interessante que mais do que usar os serviços ofertados pelo Centro Educacional, interessava-lhe acessar à bagagem intelectual do docente, para o estabelecimento de conversas e trocas de conhecimento.

Um exemplo de aproximação realizada junto ao corpo docente do CEU foi feito pela própria Nair, em 2014, quando o CEU inaugurou a Biblioteca de Educação em Direitos Humanos, como parte das ações da Comissão Municipal da Verdade Vladimir Herzog, da Coordenação de Direito à Memória. (PORTAL EDUCAÇÃO EM DIREITOS HUMANOS, 2015)

Pude perceber que mesmo adotando a estratégia de aproximação junto ao corpo docente, Nair avalia algumas falhas de atuação do CEU, como em não integrar as mulheres que frequentam seus espaços. A crítica se estendeu ao Conselho Gestor pela sua 
incapacidade de escuta e integração. Conforme pude observar, alguns dos objetivos de Nair era a união e organização das mulheres previamente às reuniões do Conselho, com objetivo da promoção da discussão de "várias questões", assim como combinar o posicionamento político diante do embate dos outros grupos no espaço e organizar a atuação representante:

Então foi assim: a gente tentou mas como a gente não tinha... Porque, veja bem, se eu converso com você antes, nós vamos discutir pontos de vista, e eu não posso ficar discutindo ponto de vista ali na frente do outro, que pensa de outra... Quer dizer, eu tenho que ter, "olha, nós pensamos assim, nós pensamos assim, nós pensamos aquilo e nós votamos todos iguais". Agora, se eu penso, como comunidade de um jeito, você pensa do outro, lógico que o interesse aqui é... Não estou julgando. Eles têm os pontos de vista, mas eu tenho os meus pontos de vista.

Nair relata não ter conseguido dar conta de reunir as mulheres antes das reuniões, porque entendia que era inviável, do ponto de vista político, fazer tratativas, esclarecer dúvidas e ocupar o espaço público de forma organizada, como um coletivo de mulheres, na frente das outras pessoas. Ela não soube afirmar qual o principal motivo que a impediu de organizá-las. Levanta a possibilidade da falta de tempo, todavia lembra da força das mulheres:

Sim, sim, foi uma grande questão, é a grande questão. É a falta de, não sei se é tempo, porque eu não sei você, Cristiane, mas tempo a gente não tem, a gente faz. Eu acho que também tem que entender isso, enquanto mulheres. Eu acho que as mulheres são muito fortes, elas entendem isso, elas têm essa condição de entender, pela força que elas têm nesse lugar.

Conforme diversas críticas apontadas pela ex-conselheira, obstáculo à participação das mulheres era o da própria instituição. Mesmo com a atuação de um grupo de mulheres fortes, empenhadas e comprometidas com a causa coletiva, de nada valerá se o Centro Educacional não se dispuser a ouvir a comunidade, promover a visibilidade dos protagonistas sociais e organizar o Conselho Gestor, de forma a ser um canal da comunidade com a instituição.

Outro problema apontado por Nair, assim como Mercedes, refere-se às atividades e ações do equipamento estarem voltadas, exclusivamente, para o ambiente escolar em horário das aulas. Nair questiona que as atividades não são pensadas para quem está trabalhando e estudando, em horários e dias alternativos, o que exclui determinado tipo de público:

Agora, o porquê que se torna tão difícil. Até porque tudo é pensado para um ambiente escolar, para um ambiente de educação, onde os horários são adequados para isso, as pautas não são abertas. Por exemplo: a comunidade vai poder participar tal dia, tal dia, 'péra' aí. Mas não dá; por 
exemplo: uma pessoa de trinta anos, ela tem que estar correndo atrás da vida e se ela está aqui dentro, tudo bem, mas e se ela não está? Como fazer para que essa pessoa possa participar em outro dia? Eu acho que tem que se começar a pensar essas coisas diferentes. Você está entendendo? O mundo funciona de outra forma. Agora, eu acho que é muito difícil quando você tem que vir participar e pensar nisso. Quem está aqui dentro tem que pensar.

Mercedes fala da relação do espaço educacional do CEU com as pessoas que circulam nas atividades esportivas:

Eu ainda falei, gente, isso daqui é um $\mathrm{CEU}$, isso daqui não é só uma escola. Porque às vezes até foge da cabeça das professoras. Porque elas estão na área educacional, com os alunos ali; só que o lado de lá é entrae-sai direto; porque as salas de ginástica são passagem ...

Conforme Nair, cabe aos responsáveis pela gestão pensar na melhor forma de resolver essas questões e não a comunidade. O chamado dela é para a construção de uma estratégia de aproximação da comunidade, que considere diversos aspectos, dentre eles a necessidade de adaptação do equipamento a outros públicos, para além do escolar.

Para Nair, é necessário pensar na inclusão de todos os grupos e faixas etárias, e cabe somente aos profissionais que trabalham no equipamento refletirem em ações para atrair diferentes públicos, como, por exemplo, explorar o recurso da comunicação de forma que seja inteligível à comunidade:

Então como que a pessoa vai participar? Como que uma pessoa, que tem que fazer faculdade e que estuda vai poder participar ali na sua comunidade? Aí você tem o pessoal que é mais idoso: "Ah, mas aquele não serve, porque a maneira que ele pensa é arcaica". Então fica tudo muito difícil. E eu acho que quem está aqui dentro, 'os cabeças' que têm que pensar, como que eu posso alcançar essa população, nossa comunidade. Como que eu posso atrair essas mulheres para cá? Como que eu posso? E eu acho que uma das grandes coisas é a comunicação. Se não tem comunicação, não fica interessante. Se eu não entendo o que você fala, se eu não entendo o seu discurso e se você não quer entender o meu...

Nair atribui a dificuldade de participação no Conselho Gestor não à existência de obstáculos externos ao equipamento educacional, mas às dificuldades originárias no interior do próprio CEU: "E eu não acredito que a dificuldade seja do lado de fora, não. Eu acredito que a dificuldade esteja do lado de dentro".

A conselheira Renata relata sua relação com a gestão. Menciona a receptividade de acolhimento da gestão em receber pautas e sugestões para a reunião do Conselho fora do dia e do espaço do Conselho: 
Se você tiver alguma coisa para estar relatando a ela, você pode estar vindo na gestão, ela é bem aberta. Se ela achar, a gente põe na pauta da reunião, Renata, e a gente discute lá no Conselho, ela faz assim.

Como a pauta da reunião já chega pronta no dia do encontro, após a leitura da ata, os presentes têm espaço para incorporação de outros temas no debate e apresentação aos demais. Até a ocasião da entrevista, Renata conta não ter trazido nenhuma demanda a ser discutida no Conselho Gestor. Assim como Mercedes, ela diz ser possível o encaminhamento de assuntos com a gestora, não somente nos encontros mensais, mas pelos corredores do CEU: "Se você tiver alguma outra pauta para acrescentar ali, ela... a gente vai discutir. Senão, no corredor também, como eu disse, ela é bem ativa com a comunidade".

Essa justaposição entre o espaço do CEU e o do Conselho também se misturam quando se trata da manutenção dos espaços. Ao longo da entrevista com Mercedes, percebi o tom reivindicatório do seu discurso relacionado à situação do CEU e da comunidade, desde o lixo nas ruas, passando pela reivindicação por colchonetes limpos na sala de ginástica do centro educativo ao seu cuidado com o teto da biblioteca que tinha bastante umidade. A reivindicação feita no espaço do Conselho, por Mercedes, também é estendida para o espaço do CEU como um todo. O sentido de participação para Mercedes envolve a atuação nos outros espaços do CEU, como a zeladoria e a fiscalização de equipamentos e materiais durante as aulas esportivas no Centro Educacional.

\subsubsection{Dificuldades de estabelecer necessidades conjuntas: estou um pouco sem poesia}

São vários os indícios nos comentários das entrevistadas que revelam as dificuldades encontradas pela participante Nair em estabelecer relações com grupos no interior do CEU. Percebi um empenho na tentativa de agrupamento que em certo momento se transforma em frustração pelo objetivo não alcançado. $O$ relato abaixo da conselheira Nair exemplifica sua intenção no esforço de reunir o grupo de mulheres para além do espaço do Conselho Gestor com o intuito de fortalecimento das pautas. Para isso, a conselheira buscou visitar as mulheres em sua residência para organização prévia ao encontro mensal no Conselho:

Porque a gente não se conversava fora do CEU. Então não... não falando... eu fui procurar várias delas, fui até a casa delas; falei, nós precisamos nos reunir, nós precisamos já levar pautas, não eles tem que trazer pra gente, nós temos que levar pautas e... era muito... foi muito difícil, eu não consegui, não consegui, então isso fez com que eu desistisse, porque... a gente precisava... precisa ter força; e, é... força só com... união... 
Ela centrou seu esforço em procurar as mulheres do Conselho em suas residências e reconhece que havia uma impossibilidade de motivação pessoal por parte delas:

Eu procurei só as mulheres, só as mulheres porque, se já era difícil... Cheguei a marcar, cheguei a ir na casa delas, tirando toda a dificuldade, toda a questão... É pessoal, porque eu entendo que o pessoal, ele não pode... Se você fazer um trabalho assim, você tem que deixar... Como eu falei, não que eu tiro o mérito de cada uma, mas elas são muito fortes; só que não tinha união.

A justificativa de impedimento da organização das mulheres, insinuada por Nair, seria a falta de tempo pelo acúmulo de trabalho doméstico e do trabalho fora de casa: “Trabalham, trabalham fora" - razão pela qual domingo seria o único dia disponível das mulheres em participar. A ex-conselheira também destaca o apoio recebido pelas mulheres que ela representava:

Elas me davam todo apoio, elas ajudavam... Se fosse uma coisa de vir fora, sabe; domingo, tudo bem; mas fora isso elas não podiam.

Na passagem abaixo, é importante reparar que Nair menciona ser representante do grupo de mulheres, mas almejava poder representá-las quando ausentes nos encontros. A frustração de não ter conseguido reuni-las foi um dos motivos alegados da saída de Nair do espaço do Conselho:

E assim que você tenha uma boa vontade, você se enfraquece, entendeu? E não consegui me unir, porque eu como eu falei para você, eu venho dessa, não vou dizer "método", dessa coisa. Eu não consigo fazer nada sozinha. Eu aprendi isso e isso eu levo para minha vida. Então como eu não consegui me unir fora a isso, isso foi um ponto para mim que fez com que eu desistisse de participar. Porque a gente não tinha, não conseguia criar bases fora. $\mathrm{E}$ as mulheres com que eu tinha bases forte, e que pensam dessa forma, infelizmente, porque eu já representava essas mulheres. Porque, por trás de mim, tinha dez ou quinze outras mulheres, só que todas elas trabalhavam e não podiam estar aqui.

Mesmo com a impossibilidade de participação das mulheres ao longo da semana, pela falta de tempo, já que trabalhavam fora de casa, Nair atribui a outro motivo da desunião:

É como eu falei para você. Há dois... um tempo atrás... é... eu vejo... Eu estou um pouco sem poesia, então acho que você tem uma coisa que é humana e muito forte. E a mulher tem essa coisa mesmo de competitividade, você está entendendo? Existe algo muito maior que a sobrevivência, de se colocar. Então quando você começa a colocar as suas coisas pessoais à frente de algumas, de alguns interesses, ficam os conflitos. Então, o conflito, ele impede...

Ela compreende que a manutenção da "sobrevivência" obriga as mulheres a saírem de casa para vender sua força de trabalho e, consequentemente, de renúncia de "alguns 
interesses" de participação coletiva. Salienta que seu projeto passava pelo aproveitamento da força das mulheres e menos pelo alinhamento ideológico delas:

Olha, não importa, eu não concordo com a Cristiane... Cristiane, em isso aqui, mas isso aqui a gente vai fazer junto. Que é o que eu vejo; vejo, assim, que elas têm muita força; então, é o que eu mais queria pegar, mais queria juntar essa força. Mas se eu... Não é se eu gosto de [amarelo], mas eu queria pegar a força que elas têm, que isso eu vejo muito forte aqui. Mas não consegui.

$\mathrm{Na}$ ocasião da entrevista, quando já estava fora do Conselho, Nair conta que passou a ter uma relação meramente instrumental com o CEU:

Faço, eu faço atividade física, mas só isso também. Mas também não é uma coisa que não passa. Eu acho, assim não passa daqui. Você vem, faz, "Tchau, tchau, professor", mas não cria laço, o próprio ambiente já não, pelo menos no meu entender...

\subsubsection{Sobre o uso do CEU como espaço cultural e como espaço educacional: como educador, ele tem que olhar no entorno}

Um ponto que foi abordado pelas conselheiras durante as entrevistas foi o acesso ao CEU e o uso do espaço público. Mercedes, uma das conselheiras entrevistadas, lembrou que a participação dos jovens no espaço público do CEU, muitas vezes, ocorre com desrespeito e uso excessivo e inadequado de palavrões. Outra conselheira, Nair, compara dois modelos distintos de acesso ao CEU, como os Centros Culturais da rede Sesc, e reivindica que os Centros Educacionais Unificados municipais possam ter acesso ao público similarmente ao Sesc, sem a necessidade de apresentação de documento. O Sesc é uma instituição brasileira privada, mantida pelo setor empresarial do comércio de bens, serviços e turismo, com atuação em todo âmbito nacional. Embora tenha suas atividades voltadas prioritariamente para seus empregados e familiares, é aberto à comunidade em geral. Ydeliz Coelho de Souza Sanches refere-se aos vínculos de sociabilidade no CEU como "criados e recriados nos jogos e campeonatos de futebol ou outras modalidades esportivas" de atuação coletiva "em prol de suas necessidades específicas, como o grupo da terceira, entre outras vivências." (SANCHES, 2014, p. 325)

Se para os jovens o CEU é local diário de sociabilidade que os mantêm com o espaço escolar, também não deixa de ser um espaço de encontro da geração mais antiga. A maioria das mulheres entrevistadas usa o espaço, quase cotidianamente, na prática de atividade esportiva, e elas se encontram com os jovens, durante a entrada, intervalos ou término das aulas escolares. Frequentemente, também por sediar atividades culturais, o Centro Educacional abriga eventos que propiciam momentos em que esses públicos etários 
distintos se encontrem, seja em apresentações de peça teatral, show musical ou durante as festividades tradicionais que ocorrem ao longo do ano, como da Festa da Cultura Brasileira e na Virada Cultural.

O encontro de Mercedes com os jovens ocorre quando ela está presente no Centro Educacional para participar das atividades físicas. E a observação abaixo retrata sua percepção quando do compartilhamento do espaço com grupo etário distinto:

Mas veja bem, os jovens quando se reúnem, ninguém contém jovem. Só que tem uns jovens, tem aquele lá. Que nem, eu acho muito legal quando eu vejo jovens discutindo sobre música, teatro, ou querem entrar nessa de teatro, música, de letras de música, não sei o quê. Até aí é um espaço que dá para você, ali, debater, mas respeitando o espaço público. Eles falando, conversando sobre livros, ou até mesmo sobre televisão ou uma mídia e tudo mais. Mas, 'fia', você tem que se limitar, você tem que respeitar o ambiente que você está; a partir do momento que você entra do portão para dentro você, em algum momento, você não... de repente você não tem hábito. Mas em algum momento de raiva, assim, você fala um palavrão.

Mercedes chama atenção para o comportamento dos jovens em espaço educacional e menciona as atividades de música e teatro que se relacionam com eles em associação aos eventos promovidos no espaço do CEU.

Na sequência, a conselheira lembra da educação de seus filhos e da necessidade de engendrar mecanismos de retenção de algum comportamento dos jovens, considerado inadequado no espaço educacional: "Então você mesmo tem que criar barreiras e seria bom, isso. Quanto a esses jovens, essas crianças. Os meus filhos dos meus filhos, eles não”.

E prossegue depoimento, ao resgatar memória de um determinado período na educação dos filhos que deixou marcas positivas, em referência à importância das intervenções educativas aos jovens: "Na época do meu filho, e ele aprendeu através disso, e foi na escola, além de eu ter ensinado em casa. Eles fizeram um trabalho". E prossegue:

E, nossa, daí eles tiraram foto de lixo, às vezes de esgoto, a água que saía por fora, esgoto, ruas que tinham. A gente tinha os nossos animais, cachorros, que defecavam nas ruas e o povo não limpava, garrafas, bituca de cigarro jogada. E ao mesmo tempo, outros que já começaram a se voltar para isso e querer ver o lugar mais bonito.

Maria Cristina Cavaleiro (2009) trata de que forma "os tempos, espaços e projetos" podem ser ressignificados na escola, como espaço sociocultural, o que compreende desde seu equipamento físico até as relações entre os sujeitos que lá atuam. O cotidiano escolar possibilita a análise dos diferentes papéis e das relações contínuas de construção de tensões e negociações entre os sujeitos que compõem a escola. A diversidade de culturas, gênero, 
raça/etnias, valores, sentimentos, emoções e projetos que se relacionam no ambiente escolar possibilita aos sujeitos o contínuo processo de aprendizagem "nem sempre convergentes e harmoniosos do ponto de vista de suas prioridades e objetivos políticos; esse conjunto inclui, além da família e da própria escola, uma ampla e variada gama de processos de socialização e sociabilidades". (CAVALEIRO, 2009, p. 51)

Assim como Nair, Mercedes aponta característica escolar proeminente do CEU que se sobrepõe ao caráter cultural e esportivo, por exemplo, das demais áreas e atividades. Segundo Mercedes, ao valorizar, exclusivamente a atividade escolar no prédio, privilegiam-se os alunos e alunas, em detrimento das atividades culturais e esportivas, onde predominam usuários e usuárias de faixa etária mais elevada. Sendo assim, percebe-se uma disputa geracional de reconhecimento do espaço, no trecho a seguir:

Só que eles também têm que entender que isso daqui não é uma escola normal. Eu vivo falando, gente, você tem que levar para o lado de não é só escola, isso daqui é um Centro Educacional, mas o direito que os seus alunos têm, eu também tenho, como usuária, como aluna. Se eu não fosse aluna do esporte, eu seria usuária do espaço; eu quero usar a biblioteca, eu uso; eu vim no teatro, eu venho.

O desejo de Nair é que o CEU fosse frequentado por um público maior. Para ela, o estabelecimento tem caráter escolar, e sua conclusão é de que os frequentadores têm ligação com escola ou tem filho em idade escolar, deixando de atrair o público de uma forma geral. Usa o exemplo de seu esposo que por não ter filhos em idade escolar, não se sente motivado de entrar no CEU:

Mais movimentado, mais... gostoso, e... E aí ele começou vir, mas não. É como eu te falei: tem cara de escola. Então, quem que vai entrar na escola se não tem um filho na escola? Mesmo na escola tem o horário da secretaria... Então tem cara de escola. Então não atrai.

Ela defende que o projeto original do Centro Educacional contemplasse um papel cultural para além de um estabelecimento educacional, equiparando-se a um ponto de cultura, como o Sesc, caracterizado pela alta "rotatividade de cultura". Entretanto, sua percepção é que o estabelecimento do CEU tem sido pouco utilizado pela população, devido, principalmente, às inúmeras discussões sobre este tema não ter avançado, ao longo das gestões anteriores.

A proposta original do CEU, imaginada por Nair, previu o Centro Educacional Unificado como um espaço que não restringisse o acesso da população, e nem que esse acesso da população fosse feito com base em um julgamento da aparência das pessoas, que leve a algum tipo de indagação do que "as pessoas vão fazer lá". Ela reivindica a proposta 
original do CEU, como um espaço de convívio, de promoção de conhecimento e "algo mais":

Então para mim, para o Seu João, que ele trabalha ali na fábrica, não sei o que, não sei o que, para ele entrar aqui é muito difícil e, se ele encontrar algum tipo de barreira, ele não vai voltar.

Ao ser obrigada a apresentar a carteirinha de identificação para "acessar alguns lugares", declara já ter sido sua entrada barrada, quando não estava em posse do documento, mesmo sendo moradora da região e usuária frequente das atividades do CEU.

A conselheira lembra que a apropriação do espaço público também faz parte do processo educativo para um olhar de cuidado do entorno e toma como exemplo a via pública do escadão abandonado nas proximidades do CEU:

Então, como educador, ele tem que olhar no entorno, e tem que ver a educação é a única coisa que eu acho que vai poder. Então você imagina, eu passando ali, você passando ali. Primeiro que é super saudável, você sobe, desce escada, um 'exercicinho'.

Embora utilize as instalações do Centro Educacional para realizar atividades físicas, Nair critica a falta de promoção de atividades de lazer no espaço do CEU, que no passado contava com a oferta de eventos de cinema e teatro. Sugere a criação de uma cafeteria no CEU, espaço organizado e gerido por moradoras da região, que além da prestação de serviço à comunidade e de atratividade ao CEU, seria uma oportunidade de geração de emprego e renda para aquelas que buscam trabalho fora de casa.

Nair tem o desejo de que o CEU se transforme em um espaço atrativo para as mulheres, e que elas se ocupem com atividades em lugar de dispenderem tempo de frente para a televisão. Critica a forma como o equipamento educacional impede a participação das mulheres:

Eu gostaria muito que o CEU se transformasse esse lugar. A minha intenção é que o CEU tirasse essas mulheres da frente da televisão e que ele fosse uma coisa mais atrativa. Você está entendendo? Agora, quando você tem o funcionamento da forma que é, você impede isso também, entendeu?

Nair lembra de uma época quando se comentava que o espaço do CEU iria disputar público com as mulheres das igrejas na região e, portanto, elas não iriam comparecer ao espaço público:

Quando eu cheguei aqui no CEU, as pessoas falavam que as mulheres não participavam por questão da igreja e por questão, que elas não estavam neste local, nesse determinado horário, sete, oito, nove por 
causa... Aí eu falo, como que é que você pode ter um parecer deste? Como as pessoas aqui diziam isto?

$\mathrm{Na}$ época dos comentários, Nair conta ter se posicionado contrária à ideia de que o CEU iria concorrer com o público das igrejas, mas que eram os maridos que impediam a presença das mulheres no equipamento:

Eu vou dizer para você: sabe o que impede as mulheres de estarem aqui? Os maridos, que querem que elas estejam em casa nesse horário para esquentar a janta, e a novela. Porque eu conheço as mulheres daqui...

Fica clara a relação de poder entre homens e mulheres e a desigualdade que permeia a responsabilidade dos afazeres domésticos, dificultando a participação das mulheres no Centro Educacional, segundo relato da conselheira Nair.

Nair, ao contrário das outras conselheiras entrevistadas, aponta o impedimento das atividades de lazer, fazendo referência à socialização de gênero que responsabiliza exclusivamente às mulheres o trabalho doméstico. Sair de casa significa, de algum modo, distanciar-se do patriarcado, que é um sistema social que usa a diferença sexual para a subordinação e opressão na esfera familiar, do pai sobre esposa e/ou filhas/os. (PISCITELLI, 2009) Para Nair, o argumento de que a "mulher tem essa coisa de não conseguir ficar parada" deve ser revisto:

É outra coisa também que a gente tem que aprender e reaprender a ter que estar focado porque a gente tem uma servidão terrível. A gente não aprende, a gente não consegue falar: 'Eu vou ficar hoje de perna para o ar', mas eu consigo fazer isso.

Quando indagada se ela utilizava o CEU como espaço de lazer, Nair responde com outra pergunta: "O que que você acha que tem aqui, para fazer lazer aqui?"

Para ela, não há atratividade de lazer no equipamento, mesmo que a ideia original tenha previsto tal oferta à comunidade. Menciona a reivindicação de um espaço no Centro Educacional, destinado à prestação de serviço comercial: "era para ter até uma cafeteria". Lamenta que existam algumas "coisas políticas que eu não sei, não ajuda" que contribuem para dificultar o acesso de oportunidades à comunidade. Para ela, a burocracia seria o impeditivo de implantação da proposta da cafeteria. Ainda completa, sugerindo que tal proposta poderia ser operacionalizada pelas próprias mulheres da comunidade, aproveitando a mão de obra da região:

Poderia, mas é poder público. Tem umas coisas políticas que eu não sei, não ajuda! Por que que eu tenho que tomar café lá... por que que não podia ter alguma coisa aqui? Ou a própria comunidade usufruir disto? Assim, mulheres fazerem um trabalho, assim, sabe, essas mulheres, em vez de ir para fora, ter que trabalhar fora... 
Também enxerga como forma de valorização da comunidade a necessidade da promoção cultural para além da que vem sendo feito, de modo que se possa enaltecer os artistas da localidade:

Teve várias coisas voltadas a cultura, mas, assim eu gosto muito da Fernanda Montenegro, adoro, só que ela passou aqui, e a gente tentou fazer cultura para que ficasse aqui, um polo de cultura, mas não ficou, porque não foi desenvolvido na região. E tem muita gente boa aqui, que faz cultura.

$\mathrm{Na}$ temática do reconhecimento, Nair reivindica a valorização do espaço e dos artistas locais. Chama atenção para que o reconhecimento e valorização seja feita pela instituição educacional, além da cessão do espaço aos artistas locais. Reivindica que a valorização e o reconhecimento feito pela instituição educacional não esteja restrito aos artistas do território, mas quando a comunidade ocupa o espaço. Mesmo que não tenha seu nome acertado, surpreende-se por ser lembrada:

Esse rapaz que voltou aqui, que falou, "Oi, Júlia", não sei o quê, ele esteve aqui em 2008. Como que ele lembra de mim? E como que as pessoas daqui do CEU não sabiam quem eu era?

No trecho acima, pude perceber a contradição da instituição educacional ao não a reconhecer como usuária, no período em que participava da comunidade educacional. Ao não a reconhecer como integrante da comunidade e usuária do espaço, a instituição exige que Nair apresente documentação para transitar no espaço que lhe pertence. A crítica de Nair é legítima, porque à medida que o Conselho a reconhece como uma participante, se contradiz ao exigir documentação de acesso ao equipamento que atua como conselheira voluntária. Exigir que o CEU seja mais aberto e menos burocrático, ao mesmo tempo em que atende a uma necessidade das mulheres, também significa "fazer política", o que Nair pratica no espaço do Conselho. Como se já não bastasse o esforço que as mulheres fazem para sair de casa, se desgarrar dos afazeres domésticos, das obrigações junto aos cuidados familiares, quando chegam ao espaço que as deveria acolher, esse lhe exige credenciais de acesso. Elas entendem que o reconhecimento da instituição deveria ser compulsório, já que elas se dedicam às atividades no espaço, há uma frustação de expectativa, motivo pela qual se desligam do colegiado, como ocorrido com Nair: "E não sabem quem eu sou. Que eu preciso mostrar uma carteirinha para entrar aqui. Você entende?" E completa:

Por que 2008, ele lembra de mim? E por que que as pessoas que estão aqui, eu não posso entrar sem uma carteirinha, aqui dentro? Sem me identificar e falar onde eu vou? 


\subsection{A PARTICIPAÇÃO NO CONSELHO GESTOR DO CEU: EMPODERAMENTOS PESSOAIS}

Das cinco mulheres conselheiras entrevistadas, a maioria tem acima dos 50 anos, e nenhuma das mulheres trabalha fora de casa, todavia somente Mercedes realiza trabalho eventual remunerado em sua casa com artesanato de pulseiras, da fábrica onde sua filha trabalha como autônoma. Isso explica que a participação no CEU e no Conselho Gestor somente se intensifica quando as mulheres param de trabalhar fora de casa, ainda que todas mulheres permaneçam como principais responsáveis pelo trabalho doméstico, em um momento da vida que estão desobrigadas no cuidado dos filhos criados e crescidos. Foram considerados alguns trechos da entrevista com a atual gestora, sobretudo aqueles relacionados aos conflitos e que contribuíam para dirimir as dúvidas.

Devido à proximidade de casa, o CEU se torna a oportunidade viável diante da economia de tempo e custos de deslocamento a outro equipamento na cidade. Pela idade e por problemas de saúde, a proximidade do CEU acaba sendo a melhor opção de espaço público para as mulheres do bairro. O espaço educacional representa o local que oportuniza uma condição de vida de cuidado consigo mesma, ao contrário de um passado em que se dedicavam, exclusivamente, aos outros. A vivência no CEU permite a ampliação da rede de contato social, o reconhecimento como mulheres atuantes e o empoderamento delas. Embora sem definição para a língua portuguesa, o conceito de empoderamento, segundo elaboração de Bruschini e colaboradoras (1998, p. 71) “designa o processo de fortalecimento político das mulheres obtido através de múltiplas ações de ordem legal, econômica, cultural e psicológica".

Como as relações e as trocas que se estabelecem no espaço público, às vezes, não lhes bastam, as mulheres buscam oportunidades de ampliar o conhecimento ao voltarem a estudar. O significado da participação no CEU é inúmero e lhes confere um retorno de bemestar da qual elas carecem, principalmente em um período da vida em que se encontram no maior isolamento social.

A despeito dos conflitos relatados pelas conselheiras, tanto em espaço público quanto privado, é certo que a participação no CEU trouxe contribuições para as mulheres, que passam a (re)significar a vida a partir de outra perspectiva. A maioria delas, com faixa etária mais elevada, passam a refletir e a questionar o desejo do marido de vê-la à disposição no preparo dos afazeres domésticos. Quando inseridas no espaço público, também vivenciam divergências que as levam à reflexão sobre a importância da educação e da organização coletiva. Percebem como as pessoas se tornam frágeis e "deformadas" quando 
não acessam à educação, e vivenciam na pele também a exclusão social que as silencia e as invisibiliza. As mulheres do CEU dedicaram toda uma vida ao cuidado e ao acolhimento dos outros; quando acessam ao espaço público do CEU, reivindicam cidadania, encontram barreiras, muitas delas contraditórias ao próprio Centro Educacional.

\subsubsection{Começam a cuidar mais de si-Eu acho que eu sou uma pessoa ativa}

Não resta dúvidas de que a participação no CEU trouxe contribuições para a vida das mulheres entrevistadas. E esse tipo de contribuição na vida delas pode significar desde a adoção de práticas de atividades físicas no cuidado com a saúde, como até mesmo o bemestar e a sociabilização, advindos das novas relações de amizades, do retorno aos estudos, por exemplo. Praticamente todas entrevistadas alegaram ter adotado uma rotina de cuidados com a saúde, após frequentarem o CEU. A adoção de uma agenda de atividades fora do espaço doméstico é fruto dessa participação. As conselheiras têm muito o que fazer e passam o dia se movimentando. Quando começa o dia, reservam um período para o cuidado com a saúde no CEU. Em seguida, retornam para a casa para as atividades domésticas. Quando é dia de reunião no Conselho Gestor, não agendam nenhuma atividade para que possam estar presentes no período da tarde no CEU, e se sobrar algum tempo, antes de dormir, aproveitam para atividades artesanais. A adoção de uma rotina contribui para se se sentirem ocupadas e úteis socialmente, principalmente depois de um período da vida de muito trabalho e dedicação familiar. Por isso, muitas relataram a adoção de uma agenda organizativa, frente às inúmeras atividades. A ocupação do tempo e da mente em atividades e em grupos sociais contribui também para o equilíbrio emocional, poupando-lhes do isolamento social.

Para as mulheres que se aposentaram, depois de uma vida de trabalho fora de casa, de cuidado com os filhos e afazeres domésticos, a nova fase na vida proporciona tempo de participação em atividades no CEU, que outrora não lhes era possível. Independente de qual seja a natureza da atividade, observei vantagem para a vida das mulheres entrevistadas.

Para as mulheres que sempre trabalharam, mas não se aposentaram, o espaço do CEU tem o significado de um centro esportivo. A conselheira Nair chega a associar a função do Centro Educacional Unificado a de uma academia, embora seja crítica da visão instrumental do espaço:

Não sei se você consegue. Como se você vai numa academia e... Não pode ser, isso aqui não pode funcionar como uma academia... 
Mercedes, de 53 anos, assim como Nair, não havia se aposentado na ocasião da entrevista. A conselheira se aproximou do CEU, pois reside em frente ao equipamento. Seus filhos, quando menores de idade, aprenderam natação no CEU, e desde antes da inauguração Mercedes relatou que participava do CEU:

Então, e desde quando nasceu o CEU - isso aqui era um terreno baldio eu participei desde o comecinho, sabe, assim, da limpeza do terreno.

Ainda lembra da recomendação que a ex-prefeita Marta Suplicy fez na ocasião da inauguração do CEU:

E eu, nossa, eu me lembro até hoje, eu guardo muito bem na minha cabeça, que ela deixou isso, ela construiu só que, como tudo, eles fazem, a gente até força um pouquinho, pede, fica pedindo, tudo, mas geralmente é largado. Então, como eu desfruto de tudo isso, eu e muitos moradores ...

Mercedes interpreta literalmente a recomendação da ex-prefeita. Na ocasião da entrevista, Mercedes desfrutava da participação no grupo de caminhada, mesmo sem estar matriculada, às segundas, quartas e sextas-feiras e, até aquele momento, a conselheira realizava atividades de alongamento, às terças e quintas-feiras; e os sábados eram dedicados a aulas de zumba. Contou que sua rotina de atividades físicas no CEU ocorria em dias alternados, ao longo da semana, e se fosse permitido, participaria das atividades físicas diariamente. Desde 2015, o Centro Educacional limitou a inscrição dos usuários e usuárias nas atividades esportivas. As atividades possuem duração de 1 hora, segundo a dona de casa:

Porque é assim: hoje eu faço, que eu não sou matriculada, mas venho; hoje eu só não vim porque eu estou gripada. Tem um grupo de caminhada, segunda, quarta e sexta, do professor Alexandre. Eu não estou matriculada nessas aulas, mas venho; há dois anos eu não estou e há dois anos eu faço.

E completa:

Eu faço alongamentos de terça e quinta, das seis às sete da noite. Acabou o mês passado, encerrou o projeto com a prefeitura.

Mercedes passou a organizar melhor sua agenda para poder participar das atividades do CEU e cuidar de sua saúde:

Dar conta, todo mundo dá. Eu acho que se eu já aprendi a me organizar. E outra: do mesmo modo que eu dou conta com as minhas atividades físicas; que eu sempre falo, esse horário das minhas atividades físicas, 'fia', [eu falto] só se eu 'tiver' doente...

Notei que a motivação de Mercedes é no cuidado da saúde em decorrência do aneurisma sofrido. Após ter sofrido um aneurisma cerebral, em 2010, e permanecido um 
mês na Unidade de Tratamento Intensivo (UTI), a conselheira redobrou os cuidados com a saúde:

Mas meu marido mesmo já sabe. Eu não paro para me alimentar? A mesma coisa as minhas atividades. Em 2010 eu tive um aneurisma. Eu fiquei um mês na UTI.

O cuidado de Mercedes com a saúde não se limita à prática de atividades físicas no tratamento de possíveis sequelas em decorrência do aneurisma sofrido, mas também tem outra motivação implícita que a importância de conter a ansiedade e o vício em tabaco. Para tanto, a conselheira aproveita a oportunidade de estar no CEU para conversar:

Depois disso, eu falei, gente... Só que eu sou uma pessoa muito ansiosa, também. Daí, uma das maneiras de eu diminuir o cigarro. Mas você já percebeu que eu gosto muito de falar. Uma das maneiras de eu diminuir o cigarro é estando aqui no CEU.

A percepção de Mercedes foi a de que ficar em casa, dedicada ao serviço doméstico agravaria o consumo do tabaco. Para tanto, recorre ao CEU, como forma de poder contribuir com a comunidade e se ajudar, por meio da participação em diferentes atividades:

Daí, eu comecei a perceber que se eu ficasse em casa muito, assim, voltada para o serviço, para as coisas da casa eu ia mais é fumar e fumar e fumar e ficar ali me acabando. Falei, não. Eu falei que forma que eu posso estar me ajudando e ajudando os outros? Eu falei, ah, vou começar a participar de tudo.

Devido ao problema de saúde que culminou na adoção de nova rotina de cuidados e à prática de exercícios físicos no $\mathrm{CEU}$, Mercedes questiona os estereótipos de gênero quando afirma ter mudado de comportamento na organização dos afazeres domésticos e com o tempo que dispende na limpeza de casa:

Então, depois disso tudo, desses problemas de saúde que eu tive e tudo mais, eu comecei a ser... Eu era muito chata com esse negócio de casa. Eu tinha que ter horário para tudo, minha casa tinha que estar impecável, eu tinha aquele negócio de pó, pó, todo dia limpava, todo dia queria tudo organizado, tudo no lugar; brigava muito, sabe? Hoje eu...

A estratégia de aproximação junto ao CEU feita por Mariana ocorreu pela prática de atividade física; e a partir de convite, começou a integrar o Conselho Gestor. Seu depoimento revela uma rotina diária de atividades, dentre elas o cuidado de si, que começa cedo no bairro. O trecho abaixo revela a adoção de uma agenda de atividades dedicada ao seu cuidado. Segundo Mariana, a organização da sua rotina não a impede de participar do Conselho Gestor e complementa: 
Segunda, quarta e sexta eu faço caminhada. Terça e quinta, ginástica. Aí eu chego em casa, faço alguma coisa, tem dia que eu vou em casa, tem dia que eu não vou em casa vou em outro lugar resolver alguma coisa.

Outra atividade na rotina de Mariana é o gosto por "bater perna", considerado como momento dedicado ao cuidado a sua saúde e, talvez por ocorrer fora do bairro, e estar associado ao momento de lazer, seja por ela apreciado, como pude perceber no trecho abaixo:

Às vezes. Gosto muito de bater perna. Agora eu vou na Lapa, vou fazer fisioterapia, vou fazer acupuntura.

A prática de caminhada fora do bairro com destino atividades médicas reforça a preocupação dela na manutenção no cuidado com a saúde, também mantida nas atividades físicas no Centro Educacional.

A adoção de uma rotina diária de Lilian se assemelha com a de Mariana, ambas aposentadas. Para que Lilian possa organizar sua participação nas atividades no CEU, sobretudo nas reuniões mensais do Conselho Gestor, alega reservar a data somente para o compromisso. No dia da reunião do Conselho, realiza as atividades em casa e no CEU, e após os exercícios físicos, retorna para casa para o preparo da refeição:

$\mathrm{Eu}$ marco na minha agenda. $\mathrm{O}$ dia de reunião eu não pego outro compromisso. De manhã eu faço as minhas coisas em casa que eu tenho que fazer, cuido dos meus bichinhos, aí venho para as minhas atividades, aí volto para casa, faço meu almoço, faço o que eu tenho que fazer, já aviso em casa: "oh, vou sair dez horas da atividade, tenho reunião".

A trajetória de chegada de Lilian ao Conselho Gestor também estava relacionada ao cuidado com a saúde. Motivada pelo diagnóstico de esclerose múltipla e pela vontade de matricular seu filho nas proximidades de sua residência, Lilian passa a frequentar o equipamento: "Eu sempre trabalhei fora, criei meus filhos, e depois quando eu vim pra cá eu já tinha tido o problema de saúde, aí eu fui pra minha casa e nisso eu aposentei”. Lilian afirma ter melhorado seu quadro de saúde de esclerose múltipla assim que passou a fazer parte do CEU:

Eu custei tanto, trabalhei tanto para vir para cá, eu melhorei... Você sabe que eu tenho esclerose múltipla, perdi tudo. Perdi tato, coordenação, sensibilidade, tudo. Quando eu me ocupei desse negócio que eu tinha um negócio para fazer, eu me vi com meu filho... menina, parece que você acorda, sabe, tudo melhorou, o problema está aqui. [se referindo à cabeça]. Hoje eu ando, eu vou para qualquer lugar, eu faço tudo que tem para fazer, eu acho que eu sou uma pessoa ativa, dentro das minhas limitações eu faço. 
Ao longo de seu relato, Nair menciona a participação em coletivo, denominado "Mulheres do CEU", formado em 2008, cujo objetivo era a promoção da qualidade de vida, por meio da dança e dos movimentos culturais. O grupo de mulheres continua a se reunir fora do espaço do CEU, segundo a entrevistada.

\subsubsection{Voltam a estudar - Vou voltar a estudar, vou me formar; vou dar isso para mim}

Dentre as entrevistadas, somente Nair cursava o primeiro semestre do ensino superior. As mulheres de mais tempo no Conselho, Lilian e Mariana, estudaram também, enquanto Lilian completou o antigo primário, Mariana estudou até a $7^{\circ}$ ano de ensino fundamental, interrompido por problema de saúde. Essa teria completado o ensino superior em Administração de Empresas, caso tivesse tido a oportunidade de concluir os níveis de escolaridade anteriores. Mercedes e Renata são as conselheiras com ensino médio completo.

Nair, a única estudante dentre as entrevistadas, logo que abandonou o Conselho Gestor, passou a dedicar seu tempo livre para os estudos. Inicialmente, não estava em seus planos cursar uma faculdade:

Olha, se você me perguntasse há cinco anos atrás, "Você quer fazer faculdade?", eu falava, "Não, não quero; quero outras coisas na minha vida".

Mesmo assim, Nair chegou a consultar seu esposo sobre a possibilidade de voltar a estudar. A decisão de voltar a estudar foi combinada com a opinião do marido, que planejava também continuar por um período no trabalho, sendo que ambos concluiriam juntos os compromissos. Inicialmente, Nair tinha o desejo de cursar Arquitetura e Urbanismo, entretanto, pela sua defasagem no domínio de disciplinas na área de exatas, teve que renunciar à primeira opção de curso. Mesmo cursando atualmente Nutrição, ela percebeu que a faculdade de Serviço Social seria mais viável, tendo em vista a exigência em domínio de áreas relacionadas a exatas:

O meu esposo é aposentado também, mas ele trabalha numa universidade e aí eu falei, "Paulo", conversei com ele, falei, "quanto tempo mais você pretende ficar nesse trabalho?", porque às vezes a gente tem alguns projetos para a nossa vida. Aí ele falou, "Ah, [ficar] uns cinco, seis anos mais..."; aí eu falei, "ah, quer saber de uma coisa, vou voltar a estudar, vou me formar; vou dar isso para mim..." Eu adoro arquitetura e urbanismo; aí o que que foi? Meu, tem muito cálculo aquilo... Ah, para correr atrás de tudo, estudar e correr atrás disso aqui vai ser muito difícil... 
Como a participação no Conselho Gestor estava fora de seus planos e dispondo de tempo livre, Nair decide dedicar-se aos estudos, aproveitando a oportunidade de pleitear bolsa de estudo no trabalho de seu esposo:

Uma das coisas que eu falei, "ah, já que ninguém quer aqui na comunidade, eu vou fazer um curso superior porque eu acho que isso eu posso dar para mim". É o que eu posso dar para mim. Então o meu esposo, ele tem um acesso, porque ele é um funcionário de um lugar onde ele consegue a bolsa. Não que eu não tive que fazer prova, tal, tal, tal...

Mesmo que não esteja envolvida nas tarefas do Conselho Gestor, Nair encontra dificuldades de se dedicar completamente aos estudos por conta do trabalho doméstico. Relata que organiza as tarefas de acordo com as prioridades:

Eu consigo administrar, e tem algumas coisas que você pode deixar, por exemplo, a roupa você põe ali e se você tiver pressa de uma coisa depois você lava. Esse tipo de coisa vai estar sempre te esperando ali, você está entendendo? Me prende, mas também não me domina a ponto de eu... Que nem eu te falei, eu olho para a pia, para fazer faculdade, e eu fico, Ai meu Deus...

Em razão das dificuldades em conciliar o curso superior com as atividades de cuidado doméstico, a ex-conselheira cogitou trocar o período do curso para que possa se concentrar nos estudos. A decisão de troca de turno para o período matinal possibilitaria a conselheira a administração do lar. Ela se refere ao marido quando diz que ele chega para tomar café no período que ela devia estar estudando:

Entendeu? Porque, durante o dia, você fica... e ele chega. Aí você toma um café, não sei o quê, não sei o quê. E eu e meu marido voltamos a estar juntos, então está sendo... A passagem dele é totalmente diferente: ele consegue. Se falar: eu vou. Ele faz as coisas dele, ele tem a rotina dele, agora parou, eu vou estudar.

Nair compara sua situação com os estudos ao do marido. Enquanto ele consegue se desvencilhar das tarefas de casa, ela se sente presa às "obrigações" domésticas. Ficar em casa no período matutino significa estar à disposição dos afazeres domésticos, o que comprometeria seu tempo de estudo. Os relatos de Nair mostram que a vivência no colegiado conferiu-lhe experiências que foram expressas em sua fala ao longo da entrevista. Após sair do Conselho Gestor, ela passa a acessar a um degrau maior no nível de escolaridade. O retorno aos bancos escolares lhe proporcionou ampliar os círculos sociais e de amizade no espaço acadêmico.

Antes de encerrar esse assunto, é importante eu destacar que quando Nair foi consultada sobre a necessidade de qualificação para participar do Conselho, ela respondeu 
que se for ofertada uma qualificação, que essa não seja mecânica, mas de um conhecimento que seja adequado a cada público, para que a metodologia não seja meramente repetitiva.

Já as outras mulheres, quando foram consultadas sobre a necessidade de qualificação para participar do Conselho Gestor, majoritariamente, responderam não ser preciso alguma capacitação, entretanto todas participariam, caso fosse ofertado.

Inicialmente, a conselheira Mariana não vê a necessidade de capacitação para atuar no Conselho, mas em um segundo momento percebe a dificuldade das pessoas em ouvir e falar no espaço participativo. Caso fosse ofertado formação, participaria. Percebe que a formação dialógica não se restrinja ao Conselho Gestor:

Tem gente que chega nos lugares e começa "papapa", e as vezes fala coisa que as vezes não deve, que não é assim que funciona as coisas. E nem só no Conselho, em qualquer lugar que você vai participar de qualquer reunião, um diálogo que você tem, primeiro você tem que ouvir para entender para depois você falar. E é o que as vezes tem gente que não faz isso.

Mariana compreende ser pertinente a oferta de curso de qualificação para atuação no colegiado para o envolvimento na comunidade de forma consciente do tema debatido:

Eu acharia que sim, se tivesse assim uma orientação, explicar, informação, para entender. Eu acho que isso seria legal. Porque tem gente que parece que até hoje leva naquele mundinho. E não é assim. A gente está em um mundo que a gente tem que ver, procurar entender, organizar, avaliar aquelas coisas para poder a gente está sempre envolvido nas coisas. E tem gente que não, que acha que é eu e mais ninguém. É isso, eu acho que todo mundo é capaz.

Acredita ser necessária a ampliação de espaço de participação política, como forma de aprendizado:

Acho que deveria ter mais política assim, mais gente que entendesse da política... eu acho que até, todos os lugares precisam de uma política, de termos um conhecimento, porque não adianta você dizer, falar em política e muita gente não conhecer a política. Uma coisa que eu acho é que deveria ter, assim, um curso, ou sei lá, não sei como falar certo, para sei lá, ter uma reunião por exemplo, bate papo de política, para pessoa entender o que é política. Porque tem muita gente que fala política, mas não sabe o que é.

A falta de estudos é problema que as conselheiras sentem na pele. Embora Lilian não pretenda voltar a estudar e não acredite ser necessário curso de capacitação para atuar no Conselho Gestor, já que seu conhecimento foi adquirido na prática, lamenta não ter dado continuidade aos estudos. 
Acho que agora já passou. Acho que agora não quero mais voltar, eu sei que tem curso aqui, que tem universidade aqui, muita gente faz, mas agora acho que meu tempo já passou. Não, não me interessa.

Lilian faz referência à Rede UniCEU, criado em 2013, pela Prefeitura de São Paulo, em parceria com o governo federal, que oferta cursos superiores gratuitos semipresenciais, em 46 polos educacionais nos CEUs, em São Paulo. Os cursos são oferecidos pela Univesp - Universidade Virtual do Estado de São Paulo por meio da Rede UniCEU/UAB (Universidade Aberta do Brasil). Ela lembra não ter a mesma disposição de uma amiga que aos oitenta anos se formou no curso de Letras no CEU:

Eu sei que tem amigas minhas já, aqui tinha uma senhorinha dona Dirce, ela se formou em Letras com mais de oitenta anos, eu não tenho esse pique, ela se formou aqui no $\mathrm{CEU}$, lindo, só que eu não tenho esse pique mais.

Também se diz constrangida em alguns momentos, quando determinados assuntos são discutidos no colegiado:

Não, eu não tenho nada, o que eu tenho foi o que eu vivi até hoje. É que nem eu falo eu não tenho estudo não tenho nada, foi tudo na marra. $\mathrm{E}$ nunca me exigiram nada. Eu sei que faz falta eu não ter estudado, porque eu percebo, eu não sou... Aí tem coisa que o pessoal começa a falar aí eu fico assim, não é minha área, aí eu me sinto mal, mas...

Assim como Mariana e Lilian, Mercedes não vê como crucial a demanda por formação ou capacitação para atuação no Conselho Gestor. Mesmo assim, caso fosse ofertado curso, a conselheira teria interesse, porque entende como válido o aprendizado. Sugere a criação de uma atividade instrutiva, "independente da pessoa participar ou não do Conselho", como forma de "esclarecer as pessoas", pois acredita ser uma barreira, como foi para ela: "Terem acesso, entendeu? Porque eu mesma, eu não sabia até, agora, essa eleição. Já me mandaram via e-mail todas as normas dos CEUs."

Entendeu? Aí eu vou. Eu venho nas reuniões e aprendo, sempre estou aprendendo alguma coisa...

Neste seu relato abaixo, justifica o porquê de não ter completado o ensino superior, e expõe sua dificuldade no manuseio da informática:

Menina, mas você lê, é que nem receita médica. Muitas coisas. Porque eu sou assim, eu sempre fui, sabe? É se eu estou na internet, se eu vou digitar alguma coisa, eu não tenho, eu não sou formada, assim, eu não fiz faculdade, universidade, nada. Já tentei, entrei na época, na Mackenzie e fiquei três meses, só que saí porque não tinha condições de pagar. Mas eu fico muito nervosa quando eu estou assim, na internet e tem alguém. Por isso que eu sou meio limitada com internet. Celular também eu não gosto. 
Porque eu odeio quando as pessoas começam a ler alguma coisa, e está tudo errado, menina, ou está tudo simplificado.

Renata, com o ensino médio completo, afirma não ser necessária a realização de nenhum curso para atuação no Conselho Gestor do CEU. A conselheira sugere que o grupo já detém conhecimento, mas se o curso fosse ofertado, participaria: "Não, não precisa, não há necessidade de curso, de coisa. Não, não precisa. Porque quem usa somos nós que trabalha com isso, né, que fazemos parte do Conselho".

\subsubsection{Circulam no próprio bairro e fora dele - A gente saía muito sabe, sempre tinha passeio}

Embora o tema do trabalho perpasse a trajetória de vida das mulheres conselheiras, é importante considerar na análise o tempo de lazer em suas vidas e a atividade de circulação pelo bairro, sendo o CEU um espaço que congrega atividades de lazer e esportes. Renata é a única com filhos pequenos em fase escolar. Sendo assim, acumula mais responsabilidades no cuidado dos filhos, e enxerga no CEU um espaço de alívio, diante das inúmeras tarefas diárias, das restrições de lazer em sua vida e carência de equipamentos públicos no bairro. Mirian Goldenberg (2018, p. 529), em sua pesquisa sobre a velhice, faz a relação da felicidade com a idade, pertinente para a análise do relato de Renata:

Um dos achados mais interessantes da pesquisa é a relação entre felicidade e idade. Pesquisas realizadas por economistas em 80 países, com mais de dois milhões de pessoas, descobriram uma "curva da felicidade" no formato da letra U: a felicidade é maior no início da vida, diminui ao longo dos anos chegando ao seu ponto mais baixo em torno dos 45 anos e depois começa a crescer. Eu também encontrei uma "curva da felicidade" entre as mulheres que pesquisei. As que têm entre 35 e 45 anos são as mais insatisfeitas, frustradas e exaustas. Elas reclamam, principalmente, de falta de tempo, falta de reconhecimento e falta de liberdade. Algumas ainda dizem que "falta tudo"!

Mesmo que a conselheira Renata não tenha vínculo de trabalho fora de casa, alega não dispor de tempo de lazer em razão do tempo gasto no cuidado dos filhos. Cristina Bruschini (2006), ao citar Dedecca (2004), destaca a diferença do tempo econômico dos homens é maior do que o das mulheres, ao passo que o tempo de reprodução social feminino é mais elevado que o masculino. Como o trabalho doméstico e de cuidados com a família exercido pelas mulheres não diminui, apesar os avanços tecnológicos, o aumento da jornada de trabalho na esfera econômica é prejudicial às mulheres, que veem seu tempo livre ser ocupado pelo da reprodução social e do trabalho econômico. (BRUSCHINI, 2004, p. 337) Ora, como defendem os autores, não sobra tempo de lazer e de descanso para as mulheres, 
quando compelidas ao trabalho fora de casa, porque a responsabilidade pelo trabalho doméstico e de cuidado dos familiares lhes "pertence".

A falta de dinheiro e o transporte são obstáculos ao lazer para Renata, tendo em vista a distância com regiões centrais, onde está concentrada ampla gama de lazer. Qualquer deslocamento mais próximo ao centro gasta em média 2 horas no transporte público. E completa:

A condução também que aqui é um pouquinho longe de tudo. Mas até aí, a condução, a gente encara. Eu acho que é mesmo a falta também de espaço, muitas vezes, também aqui. É muito longe de tudo aqui.

Quando se desloca pelas ruas de ônibus, enumera alguns dos principais problemas:

Primeiro: quantidade de ônibus, muito pouca. E eu sei que algumas linhas são pouca, a demanda de passageiro é pouca, mas o intervalo é muito grande e por quatro reais que a gente paga está muito bem pago. Acho que tinha que ter mais ônibus; tampam buracos, né? Ônibus deteriorados que mandam para a gente aqui, são ônibus... não são linhas de centro, são linhas horrorosas. Bom, acho que você pegou, você viu, é horrível.

Renata fala do custo financeiro acarretado pelo uso do automóvel no bairro. A precariedade da pavimentação de ruas e avenidas implica um gasto maior na manutenção de automóvel, contabilizado pela conselheira como um obstáculo para o lazer:

Quem vem de carro, não sei se você veio de carro, não sei. Quem vem de carro sofre a mesma coisa, o seu carro é deteriorado, você tem que verificar sempre uma manutenção, é umas ruas esburacadas...

Mesmo que todas as conselheiras sejam moradoras das imediações do CEU e não precisem realizam grandes deslocamentos até o CEU, a leitura sobre as condições dos meios de transporte e o tempo de lazer são válidas para tentar entender o tempo dispendido nesses trajetos, os deslocamentos pelo bairro até mesmo a importância do tempo de não trabalho na vida das mulheres trabalhadoras do Jaraguá.

Quando tem a oportunidade da prática do lazer, Renata costuma acompanhar os filhos ao cinema, parque, visitar parentes e, quase semanalmente, à "quadrinha de futebol". Considera como lazer as atividades esportivas que realiza no $\mathrm{CEU}$ :

Ah, ou é um cinema ou é trazer no parque aqui do... Que o CEU, como você pode ver, a gente tem uma estrutura muito boa. Ou é na casa da vó ou ele vai na quadrinha de futebol para jogar bola. É assim.

Ao contrário de Renata que faz um relato exclusivamente voltado à prática de lazer e circulação pelo bairro ou fora dele, o relato de Nair é intercalado pela reflexão sobre a circulação pelo bairro e o abastecimento de compras para a família. O destaque do seu cotidiano fica por conta da prioridade em comprar no bairro no incentivo da geração de 
emprego, trabalho e renda na região. Compra produtos como hortaliça, café e banana, exclusivamente, orgânicos no bairro, dessa forma conhece sempre novos produtores e faz amizades:

Por que dessa coisa de conhecer, sabe, coisas daqui: "Olha, eu tenho uma horta na minha casa, eu vendo isso, eu vendo ovos."

As relações cotidianas estabelecidas por Nair junto ao produtor orgânico na compra e/ou troca possibilita conhecer outros comerciantes que desenvolvam a cultura orgânica no bairro, valorizado por Nair. Fez recomendação aos servidores do CEU sobre a importância de explorar o bairro como forma de ampliar o conhecimento:

Tanto que essa semana eu fui na faculdade e eu aprendi. A professora estava falando sobre sazonalidade e essa semana, a Dona Ana Maria, que eu compro verduras com ela, ela, disse: "Oh, Nair, essa semana não vai ter rúcula, por conta do sol." Aí eu falei, manda o que a senhora tiver, porque elas sempre fazem assim. E é aquela coisa, só dá aquilo naquela época, então você só come aquilo naquela época. E eu acho legal, por quê? Porque é essa vivência que você vai tendo e quando você vai nos barzinhos aqui. Primeiro, que eles são muito legais. Aí você começa entender como é que funcionam aqui as coisas, como que eles pensam, como que os pais são. Então, isso foi algo que eu falei para eles. Eu achava que de vez em quando, os educadores, os gestores daqui deveriam ir, porque sempre tem a coisa. "Vamos trazer eles para cá".

Para Nair, o momento fora de casa em contato com outras pessoas pode ser entendido como um momento de lazer, como das mulheres que frequentam o CEU. E, muitas vezes, os significados de "participação" e "lazer" se misturam, porque ambos não são realizados no espaço doméstico. O significado da saída de casa para as mulheres deve ser compreendido como o momento de alívio diante das obrigações diárias domésticas, conforme o relato abaixo:

Lógico, tem que sair um pouco desse contexto de casa que eu gosto. Eu gosto de estar com pessoas. Eu gosto muito de gente, de rir e de bater papo furado. Então eu tenho uma rotina, assim... Eu tenho umas amigas que são da vida e eu e meu marido, assim, a gente se dá esse direito. Como a gente não é muito consumista, a gente gosta e a gente colocou se que a gente vai conhecer o Brasil. Então eu tenho ido para alguns lugares. Até a gente tem feito o caminho de volta, e como eu gosto muito de conhecer minhas raízes, a gente foi conhecer a família dele na Bahia, e agora eu fui conhecer a minha família. Conhecer, assim, ver o que que tinha lá da região de onde os meus pais nasceram...

Em sua pesquisa, Goldenberg (2018, p. 529-530) observa que a "curva da felicidade" está relacionada com a chegada da idade e da liberdade:

Mas eu descobri que tudo começa a melhorar a partir dos 50 anos e a curva da felicidade começa a subir. A partir dessa idade as mulheres 
começam a se sentir muito mais livres e felizes. Por quê? Em primeiro lugar, elas descobriram que o tempo é o verdadeiro capital. Elas não podem, e não querem mais, desperdiçar o próprio tempo. As mulheres mais jovens querem agradar e cuidar de todo mundo e reclamam que não têm tempo para elas. Mais velhas, elas aprendem a dizer não e passam a priorizar o tempo para cuidar delas. Aprender a dizer não é uma verdadeira revolução para as mulheres.

A tese de Goldenberg é corroborada pela fala de Nair, ao manifestar seu gosto por viajar, também destaca gostar de "passear", "ver lugares", "andar de ônibus", "ver as ruas", ir ao Sesc e conhecer "as pessoas", atividades realizadas quando elas frequentam o CEU e o Conselho Gestor:

Eu estou colocando isso na minha vida. A vida tem me dado essa condição, então a gente tem deixado a nossa vida. Eu gosto de passear, eu gosto de ver lugares, eu gosto muito de andar de ônibus, porque eu gosto de ver as ruas, as pessoas. Por exemplo, se você falar assim, "Vai lá na Praça da Sé" eu vou olhar, assim, a arquitetura, mas eu vou olhar também as pessoas. Eu gosto muito de ver as pessoas andando, se mexendo e eu tenho assim, um... eu... não sei, eu gosto disso, você está entendendo?

Nair faz uma reflexão interessante atribuindo, necessariamente, a realização do lazer à posse de dinheiro. Nessa primeira observação, ela chama atenção para o desconhecimento acerca do significado de lazer, tendo em vista que as pessoas só conhecem o significado do trabalho: "a gente não aprendeu a se divertir". Justamente pela rotina delas não possibilitarem o momento do lazer que as atividades desenvolvidas no CEU são associadas ao prazer do tempo do não trabalho:

Primeiro que nós não sabemos fazer lazer. Lazer tem a ver com gastar. Todo mundo entende que não pode fazer lazer porque não tem dinheiro, porque a gente não tem muita essa cultura de se divertir, a gente só tem cultura de trabalhar.

Do dualismo "lazer" e "trabalho", presente na sociedade, ela destaca a sobreposição do "trabalho" em detrimento do "lazer". Relata sua percepção da necessidade de modificação desse pensamento em uma sociedade que valoriza o trabalho em prejuízo do momento do lazer:

"Eu não tenho tempo, eu tenho que trabalhar", as pessoas falam isso. Meu Deus, misericórdia! E, assim você não sabe, a gente não aprendeu a se divertir, a gente não aprendeu! Então, tudo isso tem que ser muito modificado, uma coisa de simplicidade, mesmo.

No depoimento sobre sua percepção de lazer, Nair remonta ao passado do CEU. Ela faz um paralelo de prática de um lazer acessível, como da simplicidade de estar em uma roda de conversa, com a oferta de lazer do CEU no passado: 
Vai ter que mudar aquela música. Então, o lazer, eu acho que a gente tem que ser educado também nisso. As pessoas limitam muito o que é lazer, o que é se divertir, sabe? E a gente tem tanta coisa, tanta gente que tem. Por exemplo, eu gosto de estar e meus filhos adoram também, estar em uma roda de conversa e as pessoas mais velhas contam as histórias do jeito que elas falam. E o CEU agora não, mas ele deu muito essa condição para as pessoas aqui, essa questão mesmo do lazer enquanto cultura, trazia dança... Nossa, eu vi aqui como é que era o balé da cidade! Menina, eu lembro que eu fiquei.

Assim como abordado por Renata, Nair também cita o problema do deslocamento pela região como um impedimento ao lazer, considerando que durante a semana as pessoas já se desgastam no transporte público no circuito casa-trabalho, e quando possuem algum tempo de descanso não esperam traçar esse mesmo percurso, corroborando a importância do CEU em sua vida:

Eu vi gente muito boa aqui, mas também vi muita gente muito boa do bairro, também. Então se tornou isso e isto vindo até nós, para não termos que nos deslocar. Porque, meu Deus, coitada a pessoa. Você acha que a pessoa pega ônibus, trem e tudo e ela vai fazer isso no fim de semana? Ela quer mais sair disso, e se você traz isso...

O lazer para Mercedes é feito fora do bairro. Como seu esposo é praticante de corrida de rua, a conselheira aproveita para o acompanhá-lo em suas viagens de competições esportivas, costumeiramente à cidade de Pindamonhangaba, interior de São Paulo. Desde 2017, quando comprou um apartamento no litoral sul de São Paulo, sempre que pode, viaja para a Praia Grande:

Faz um ano que nós compramos, conseguimos comprar um apartamento na praia. 'Fia', se o meu marido falar hoje... hoje nem tanto, ainda... nem tanto, por conta da minha netinha, mas se ele falar, "Vamos para a praia", eu vou, largo tudo e vou. Vou, ando lá... Passeio, converso com outras pessoas, final de ano, carnaval; eu gosto muito de passear, eu estou sempre pronta... eu estou sempre... perto da minha mãe.

A experiência relatada por Mariana de sua circulação pelo bairro ou fora dele também ocorre no contexto do lazer, que acontece tanto no espaço do CEU quanto dos parques da região, e até fora do bairro, no Sesc. Interessante que o tempo de lazer é o momento fora de casa, já que o significado da casa se relaciona ao trabalho doméstico. Embora assista a novelas, sentar-se de frente à TV não é considerado como lazer:

Não, momento livre não, é passatempo. Tanto que eu não gosto muito de televisão, tanto que é assim, a minha televisão eu ligo, assisto o terço, a missa, a outra missa, aí vem a novela. Não consigo assistir filme, não tenho paciência, nem de ficar assistindo outra coisa na televisão. 
Mesmo frequentando o CEU nos dias de festividades, em que monta sua barraca para comercializar os artesanatos que produz, Mariana considera como momento de lazer as apresentações de shows:

Então, eu venho no show, quando tem festa no CEU eu monto minha barraca, de pão, as vezes eu coloco dos meus trabalhos artesanais, mas não vira não, ninguém compra nada. As peças são mais cara, e quem vem aqui não vem para comprar coisa cara, vem mais para comer. Agora se eu ponho a mesa de pão...

Antes de seu marido trabalhar como segurança nos finais de semana, Mariana costumava ir ao Parque Anhanguera, considerado por ela como "lazer da hora". Porém, como seu companheiro trabalha aos finais de semana, prefere não sair sozinha: "agora ele trabalha muito de final de semana, eu saio sozinha, não gosto de sair sozinha, de andar sozinha".

O depoimento de Lilian sobre a circulação no bairro ou fora dele é feito de forma pontual. Ela resgata algumas lembranças de passeios que realizava no CEU para contar sobre seu tempo de lazer, quando mais jovem. Percebi que o momento de lazer no presente não existe, ficou no passado. Ela mesmo conta que não tem tempo de lazer. No final do relato sobre seu cotidiano de afazeres domésticos, Lilian deixa escapar que nas horas vagas prefere exercitar a mente com palavras cruzadas e criptogramas a ver televisão, exceção somente quando assiste à novela. Para a conselheira, lazer também é passeio fora de casa, porém não inclui estar no CEU.

Pior é que não. É difícil viu. Antes tinha uns passeios legais, de dia, o Jardim Botânico, você já foi?

Lilian atribui a ausência de passeios do CEU aos cortes nos gastos públicos e, ao ser questionada se o Conselho Gestor não teria autonomia de intervir na possibilidade da oferta de passeios, Lilian responde:

Eu acredito falando da reunião, vou dar uma cutucada porque a gente saía muito sabe, sempre tinha passeio. E o pessoal até hoje me cobra, "ah e os passeios!". Não era eu que era o daqui, mas eu vou dar uma cobrada mesmo, não custa nada, porque o 'não' eu já tenho.

A conselheira lembra de sua visita a museus e piqueniques em espaços públicos:

Pois é, a gente leva as coisas, fazia piquenique, tem uma Casa Museu a gente ia, no Museu da Moeda, Museu da Casa Brasileira, tem tudo antigo. Aí eu olhava assim falava 'ó minha mãe tinha isso, minha avó tinha aquilo', era muito legal. Acabou tudo.

O espaço do Conselho Gestor também é considerado pela entrevistada como um momento de sociabilização para a participante, sair de casa, estabelecer diálogos e fazer 
amizades. Lilian entende aquele momento de reunião do Conselho como uma oportunidade no CEU, de quebra da rotina para o estabelecimento de amizades e conversas. A contradição do relato de Lilian quando ela não considera a realização de lazer no CEU, mas é no CEU que canaliza todo seu relato de lazer, desde os museus, os passeios que deixaram de acontecer e o próprio espaço do Conselho de quebra de rotina. Finalmente, quando indagada sobre as contribuições que a participação no colegiado trouxe em sua vida, Lilian lembra das "horinhas" destinadas à reunião e do caráter familiar que o Conselho é percebido:

Trouxe, trouxe sim. Porque é bom a gente se enturmar, conhecer pessoas novas, conversar. É uma horinha que eu sento, porque em casa eu não sento. Não dá tempo. Tempo de conversar. E tem as meninas aqui que é como se fosse minhas filhas, gosto muito delas. Então eu gosto.

Assim como Lilian, Mercedes também mantém uma relação familiar com os funcionários do $\mathrm{CEU}$, já que por residir em frente ao equipamento, considera os trabalhadores como pertencentes ao seu quintal de casa:

É... quando afastava algum funcionário, eu sempre perguntava: "cadê Maria?" "O que que aconteceu com a Joana?", mas sendo que esses funcionários, tanto da segurança quanto da limpeza são todos de firmas terceirizadas. Daí começou a perguntar, "Mercedes, por que é que você se importa?" A gente vai pegando uma convivência no dia a dia, aí acaba... não que sejamos amigos, mas é uma coisa, por eu morar aqui em frente, então eu sinto o CEU aqui como se fosse o quintal da minha casa, porque, eu... os momentos, assim, que eu venho fazer atividade física são os momentos só meus.

O significado das relações sociais estabelecidas no espaço educacional representa para as conselheiras ser equiparado ao ambiente familiar. Nair fala sobre isso também:

Então fica muito família; eu vejo a extensão das... do meu bairro como a minha família

Assim como o CEU é visto como extensão familiar, Nair vê como positiva sua participação no Centro Educacional, e narra a relação sinestésica que estabelece com a comunidade e quando se aproxima das pessoas:

Coisa positiva de conhecer. Eu gosto de conhecer as pessoas; dificilmente eu saio na rua, falo com duas, três pessoas. Eu acho engraçado que, assim, é... Talvez pela minha vivência, as pessoas se tornam, assim, muito... Eu não consigo ver uma pessoa e não abraçar, não beijar, essa coisa de toque.

As mulheres entrevistadas circulam no próprio bairro e fora dele. Algumas veem o Sesc e o CEU como espaços de realização do lazer. Outras lamentam que o CEU parou de 
oferecer passeios coletivos e, também, relatam que viajam com esposo. De toda forma, procuram estabelecer laços e vínculos para além do isolamento doméstico.

\subsubsection{Conselho Gestor como argumento para sair de casa, fazer amizades - Uma das maneiras de eu diminuir o cigarro é estando aqui no CEU}

Outro ponto importante, quando discutimos a participação das mulheres nos espaços públicos, é entender a motivação da saída de casa, assim como entender o significado dos obstáculos que enfrentam e/ou impedem a saída do espaço privado.

Até então, os tópicos anteriores do capítulo mostraram as razões objetivas pelas quais as mulheres vêm a público acessar ao espaço do Conselho Gestor. Sabemos, pelo menos, que os principais elementos explicativos do envolvimento das mulheres com o CEU, dentre as entrevistadas, começam na luta por educação aos filhos e a busca de atividades físicas para o cuidado da saúde. Se o pontapé inicial para a saída do espaço privado e acesso ao Centro Educacional começa, principalmente, pela matrícula aos filhos ou com a finalidade de cuidado com a saúde. Neste tópico me proponho a entender o que está por detrás da subjetividade das mulheres ocuparem o espaço público.

Embora eu já tenha mencionado ao longo do capítulo o depoimento de Mercedes, o trecho a seguir exemplifica perfeitamente como que é feita a organização prévia das mulheres ao acessar o espaço do Conselho Gestor, os motivos explícitos dessa saída e os obstáculos que elas enfrentam:

Eu sempre falo que esse horário das minhas atividades físicas, só se eu estiver doente não vou. Mas meu marido mesmo já sabe. Eu não paro para me alimentar? A mesma coisa as minhas atividades. Em 2010 eu tive um aneurisma. Eu fiquei um mês na UTI.

A motivação de Mercedes é no cuidado da saúde em decorrência do aneurisma sofrido em 2010. O CEU tornou-se um espaço profícuo para o tratamento de Mercedes, já que as atividades físicas, visitas frequentes ao centro e encontros com as pessoas têm contribuído para a redução da ansiedade e do vício do cigarro. É neste sentido que o CEU atua como um espaço terapêutico, de cura do isolamento e do peso do trabalho doméstico para essas mulheres.

Mercedes diz que o vício pelo cigarro é ocasionado pelo tempo solitário em casa, e o controle da ansiedade ocorre justamente com a organização de seu tempo; tempo esse que é gasto em atividades no Centro Educacional:

Então a forma de eu saber lidar comigo é que eu vou ter que saber dividir o meu tempo e as minhas ansiedades e as minhas vontades. comigo 
mesma. É através eu falei, eu penso comigo: se eu fico em casa, porque é eu já percebi que eu fumo muito por conta de ficar sozinha.

A dificuldade de se desvencilhar das atividades domésticas é relatada abaixo por Nair em sua saída do espaço doméstica. Há um esforço em deixar as responsabilidades domésticas de lado para se dedicar aos estudos na faculdade. Em seu relato, Nair deixa claro haver distinção da dificuldade que enfrenta quando sai de casa para frequentar o CEU e a faculdade. A maior frequência às aulas diárias torna mais penosa sua participação no espaço acadêmico, enquanto as reuniões mensais no Conselho Gestor são mais flexíveis, do ponto de vista das responsabilidades domésticas. A dificuldade em se desvencilhar dos afazeres domésticos é maior quando seu tempo concorre com o horário de estudos, diariamente, do que com sua participação mensal no Conselho Gestor. A participação no Conselho lhe toma menos tempo dispendido nos afazeres do lar.

Percebo que Nair revela sua tentativa de diminuir as atividades domésticas, feito que diz ter obtido quando participava das reuniões do Conselho Gestor. Contudo percebe a dificuldade de adoção dessa postura em sua rotina. Uma vez aceita a identidade como expressão de dona de casa, e não como um sentido em si do sujeito, "a identidade é performativamente construída”. (BUTLER, 2003, p. 180) Nair relata esse efeito, produto da performatividade repetida ao longo da vida:

Então, eu vejo como isso está forte em mim, mesmo eu tendo um discurso aqui, eu vejo como eu não consigo me livrar disso aqui na minha mente, está entendendo? Então é um processo, assim, muito difícil. Para eu estudar está sendo muito difícil para mim sair de casa e deixar a louça sem lavar. Estou tendo que fazer esse exercício, porque eu estou entendendo assim: eu consigo fazer isso enquanto eu venho aqui participar duas horas do Conselho Gestor, mas fazer isso numa rotina está sendo, assim, muito difícil; eu estou tendo que vencer, as minhas barreiras internas. Mas como que uma louça, que qualquer um pode lavar, pode me prender a ponto de me impedir...

Nair percebe os estereótipos de gênero com base em sua experiência como estudante e dona de casa:

Eu fico pensando quanto que essas coisas dominam as mulheres. Quantas mulheres morrem porque não conseguem limpar o chão da casa, assim, perfeitamente. $\mathrm{E}$ eu estou mal porque eu não estou conseguindo. $\mathrm{E}$ às vezes eu saio de casa, assim, eu fico assim: eu tenho que fazer uma matéria, eu fico estudando, assim, aí eu olho para pia, e a minha filha até falou para mim, “'Ó', mãe, vou dar uma dica para a senhora, vai para faculdade porque se a senhora não fizer isso, a senhora não vai conseguir". Então tem um domínio muito forte.

Sair de casa para frequentar as aulas na faculdade e ir às reuniões do Conselho possuem significados distintos para a conselheira. Para a participação no Conselho, de 
frequência mensal, Nair não encontra dificuldades em participar; as aulas na faculdade, praticamente diárias, a levavam a refletir sobre o obstáculo dos afazeres domésticos em sua vida. Embora a decisão de voltar a estudar tenha sido tomada em substituição ao tempo que se dedicava ao colegiado, ao colocar em questão as razões pelas quais as tarefas domésticas a impedem de estudar, Nair percebe a dificuldade que tem em se ausentar com mais frequência de casa: "Porque realmente essa questão da casa pega muito no inconsciente, ela consegue, assim"

\subsubsection{Negociação e participação - Mas sempre tudo sobra para a mulher mesmo}

Alguns pontos na entrevista foram fundamentais para o meu entendimento sobre o sentido de participação para as conselheiras. Do ponto de vista das mulheres, a participação do Conselho Gestor e do CEU estão articulados, já que tanto a participação no CEU interfere a atuação delas como mulheres, quanto a participação no Conselho Gestor, e por isso são entendidos como o mesmo espaço.

Lilian declara convidar os integrantes de sua família a participarem do Conselho, reconhecendo a importância da participação: "Minha família nunca se envolveu, e quando alguém fala alguma coisa eu falo "não, vocês têm que ir também, vocês têm que participar também", eu chamo o pessoal. E o pessoal não vai."

Embora incentive a participação no Centro Educacional dos demais, principalmente de pais e avós que possuem filhos ou netos, Lilian atribui o déficit de participação no Conselho Gestor do CEU ao "comodismo", especialmente em sua vizinhança. Ainda segundo a conselheira, seus vizinhos deveriam colocar o espaço do CEU em funcionamento em vez de "cuidar" da vida alheia:

Eu acho que é comodismo. O tempo que elas ficam na rua, que nem eu vejo as mulheres na minha rua, o tempo que elas ficam sentadas lá, cuidando da vida dos outros, vem para cá. Vem para cá, vamos fazer diferente, vamos tentar, porque todo mundo já teve filho, já teve neto, que nem eu. Porque a gente precisa desse espaço e que funcione.

O sentido de participação para Mercedes passa pelo estabelecimento e manutenção de relações de amizades. A atuação no espaço público também subentende a administração do tempo. Como mencionado pela conselheira, há um arranjo organizacional diante das demandas cotidianas de afazeres domésticos, cuidado pessoal e com familiares, além do tempo dispendido para o trabalho eventual fora de casa, vivenciado por Mercedes. Existe o combinado antes de sair de casa, feito com base em acordo com o esposo, no trecho: “meu marido já sabe”. Essa fala de Mercedes revela a ciência do esposo diante de sua saída 
de casa. Tanto a jornada de trabalho doméstica, quanto o tempo dispendido da conselheira na participação fora de casa é operado por uma lógica organizativa, que passa pelo conhecimento do esposo sobre seu paradeiro:

Dar conta, todo mundo dá. Eu acho que se eu já aprendi a me organizar. E outra: do mesmo modo que eu dou conta com as minhas atividades físicas. Eu sempre falo que esse horário das minhas atividades físicas, só se eu estiver doente não vou. Mas meu marido mesmo já sabe. Eu não paro para me alimentar? A mesma coisa as minhas atividades. Em 2010 eu tive um aneurisma. Eu fiquei um mês na UTI.

O depoimento de Nair deixa claro a importância do gerenciamento de seu tempo e a negociação junto ao seu cônjuge para que possa se envolver nas atividades:

Eu consigo, assim, tipo: olha, hoje eu não vou fazer isso porque eu tenho isso para fazer. Por exemplo, ontem eu falei para ele amanhã eu vou sair, vou dar uma entrevista para estudante da USP. Então quando eu voltei, fiz um cafezinho para mim e o resto ele administrou.

O envolvimento de Nair com o CEU passa pela administração do tempo e de seus compromissos individuais e domésticos. A participação no CEU possibilitou o questionamento e a quebra de paradigmas sobre a organização doméstica, de forma que facilite sua vida. Interessante perceber o esforço que a conselheira Nair faz em adotar rotinas diferentes da sua mãe e avó, associando o impacto da mudança tecnológica nos afazeres de casa ao longo das gerações:

Mas eu acredito que tenha que ter, sim, uma certa ordem; é preciso isto. Eu entendo que tem que ter. Você tem que sentir. A sua casa tem que ser um lugar gostoso. É importante entender assim; eu entendo. O importante é entender que você pode fazer de uma forma diferente, não tem que ser da forma que a sua vó, que a sua mãe. Você pode pensar, porque tudo mudou, tudo mudou. Se hoje você tem a máquina de lavar, por que que você fica tanto tempo? Você está entendendo?

Observei em sua narrativa o esforço pela valorização do espaço privado no trecho a "casa tem que ser um lugar gostoso" mesmo se considerar os obstáculos que enfrenta com a rotina de trabalho doméstico neste espaço, detalhadas no tópico anterior (3.1.1).

O atual mandato do Conselho (2018-2020) elegeu usuários/as da comunidade que utilizam o equipamento, o que explica a maior participação de mulheres, segundo Renata. Quando foi solicitada à conselheira fazer comparação entre mulheres e homens no Conselho Gestor, Renata, enfaticamente afirmou haver diferenças na participação, pois as mulheres são mais ativas e decididas na tomada de decisões. Alega serem criativas sobre algum problema no equipamento escolar, enquanto os homens precisam de tempo para analisar resoluções. Essa fala de Renata sugere associação ao fato de as mulheres possuírem 
experiência, já que estão acostumadas a serem responsáveis pela criação e pelo cuidado dos filhos:

Então, a mulher, ela é mais decidida, ela tem uma visão ampla da situação e consegue desenvolver mil coisas ao mesmo tempo. Porque a Sara que a nossa gestora, ela consegue resolver isso, resolver aquilo e vem com a gente com o problema e todo mundo junto do conselho está resolvendo.

Frequentadora de todas as reuniões do Conselho Gestor, Renata afirma ser ativa e fiscal do CEU, como Mercedes, outra conselheira, com quem se comunica por telefone ou presencialmente sobre temas do Conselho Gestor. Revela que os atuais frequentadores das reuniões mensais são seis mulheres e somente dois homens, em razão da falta de tempo deles em conciliar o cargo no Conselho com atividade remunerada de emprego.

A experiência de participação no Conselho Gestor do CEU proporciona a aproximação de atribuições vivenciadas no lar, propriamente pertencentes às mulheres, conforme Renata. Ela conta exercer o cargo de "presidenta" do lar, gerenciando as atividades domésticas dos demais moradores. Portanto, a experiência de participação cumpre esse papel de dar voz e espaço às mulheres que também fazem "sua" política no campo doméstico. Caldeira (1987, p. 116) fala dos significados da participação cotidiana das mulheres:

O exemplo das mulheres é claro a esse respeito. Estão sempre ocultas por trás de categorias globais como "o povo", as "camadas populares", os "habitantes da periferia", valorizadas pelo que elas podem representar em termos de expressão de interesses de classe; pensadas pela perspectiva político-institucional da qual elas tendem a se separar; as mulheres nunca são vistas em suas vidas cotidianas e em suas especificidades. Desse modo, se criou uma visão completamente estranha dos significados que pode ter sua participação. A política, cantada em prosa e verso pelos analistas, como o aspecto central dos novos movimentos sociais, é negada e deixada de lado pela maioria das mulheres que participam deles. A nova forma de ação encontrada não é, para elas, fazer política, mas viver de uma maneira nova sua condição de mulher. (Tradução nossa)

Apesar do baixo envolvimento de mulheres no Conselho Gestor, considerando o quantitativo de moradoras no bairro, quando indagada sobre a participação de homens em relação às mulheres no Conselho Gestor, Lilian responde que é "difícil vir homem" no Conselho. A hipótese aventada pela entrevistada é a de que o trabalho remunerado, exercido fora de casa pelos homens, justifica a ausência maciça deles no espaço. Segundo ela, a baixa participação masculina está atribuída ao próprio horário em que ocorrem as reuniões (manhã/tarde), quando os homens estão exercendo seu trabalho fora de casa: 
Homem é bem pouquinho mesmo, bem pouquinho. Assim da comunidade mesmo não vem, não vem mesmo. Não sei se é porque trabalha de dia.

Ela também revê sua afirmação sobre a baixa participação das mulheres, ao associar a característica ligada à "força" as mulheres, quando comparada ao dos homens:

Eu acho que as mulheres lutam mais. Não se é porque a gente é mais envolvida. A mulher é diferente mesmo, eu acredito que sim. Que homem tem aqui? As vezes tem um rapaz que trabalha aqui, nossa, mas homem mesmo não tem, comunidade não vem, não participa.

A participação no CEU está atrelada à questão de gênero, segundo Lilian. Primeiramente, porque relaciona o caráter de lutadora às mulheres; em segundo lugar, a ausência dos homens na criação dos/as filhos/as, porque trabalham fora de casa ou porque estão nos botecos, que os distanciam do espaço:

Porque aqui na escola ninguém vem. Nem se você vê um pai trazendo um filho, participando de reunião. Mas você passa em qualquer boteco aí e está cheio. Eu acho que não quer, não quer participar. Durante o dia tem que trabalhar, depois do serviço é lazer. Mas sempre tudo sobra para a mulher mesmo. Não é assim que funciona? Eu vejo assim.

Nessa passagem é possível perceber crítica à desigualdade de responsabilidades nos cuidados dos filhos e desigualdade de oportunidades. A responsabilização no cuidado dos filhos, que recai exclusivamente sobre as mulheres, e essa sobrecarga as impossibilita do gozo de tempo de lazer, ao passo que, mesmo após o expediente, os homens desfrutam de momento recreativo. Por meio de pesquisa, redações escolares de crianças que descreviam cotidianos familiares mostraram a diferença no lazer entre pais e mães. Os desenhos denunciavam a diferença no tratamento aos domingos; as meninas eram recrutadas para a faxina, enquanto os meninos aguardavam o retorno da prima para brincar. As crianças descreviam as mães em atividades de cuidado dos irmãos menores e na limpeza doméstica, enquanto os pais estavam na pescaria (FONTOURA, 2016).

Pelas falas registradas, deduzi que as relações de gênero no espaço do Conselho Gestor são praticamente inexistentes, pois é predominante a presença das mulheres. Entre as narrativas repertoriadas sobre a presença feminina no colegiado, há duas falas que afirmam não existirem homens no Conselho Gestor. Tanto Mercedes como Nair falam da ausência dos homens. O relato de Mercedes sobre o convite feito à Renata para a participação do Conselho mostra que a conselheira se reportou somente às mulheres com a alegação de que os homens trabalham fora de casa, durante o período das reuniões: "É, porque os homens geralmente não... tem às vezes... são durante o dia." Quando a 
conselheira estabelece a comparação entre os gêneros no espaço participativo do CEU, usa como exemplo seu marido, que na condição de aposentado não gosta de participar:

Os homens não têm... Meu marido mesmo, agora que ele se aposentou, está em casa, mas ele não tem... ele não gosta, ele não...

Nair, ao tratar da distinção de comportamento entre homens e mulheres no Conselho Gestor, afirma que no período em que esteve no cargo de conselheira inexistia a presença masculina, ao menos que fosse de seu conhecimento:

Então, eu não posso dizer assim, que eu não percebi a participação de homens aqui no Conselho. Não tem, não percebi, não. Só se tiver algum agora. Mas, efetivamente, como é o da Mariana, assim, não. Dessa forma não.

Da análise, com ênfase sobre a predominância de mulheres no colegiado, posso deduzir na hipótese de que o exercício do trabalho fora de casa desempenhado pelos homens, aliada à cultura que associa o cuidado dos filhos e filhas à mãe, possibilita que o CEU e o espaço do Conselho, em especial, sejam acessível às mulheres. Em uma cultura que responsabiliza as mulheres pelo cuidado dos filhos, é mais aceitável, socialmente, a presença delas no ambiente escolar, em acompanhamento dos filhos em comparação aos homens que estão dedicados ao exercício do trabalho fora de casa. Quando os pais e maridos cumprem o expediente no local de trabalho, cabem a eles o gozo do tempo de lazer fora do espaço doméstico, na companhia de seus pares, nos bares e botecos, conforme mencionado por Lilian.

Mercedes não hesita em afirmar a importância de agregar mais mulheres no espaço do Conselho. A conselheira lembra de uma ocasião em que acionou o contato da Renata, por meio da rede social, e encaminhou algumas sugestões de ideias para a programação da Virada Cultural, em momento que precisava ouvir um feedback de alguma conselheira:

É porque tem hora que você olha para os lados assim, não tem ninguém para você... Que nem, quando eu falei para a Renata, sobre a Virada Cultural, da barraca, dos refrigerantes e quando eu saí da reunião, que eu vou para casa, eu fiquei pensando, sozinha. Daí eu mandei um WhatsApp para a Renata.

Quando solicitada a sugerir ações a serem feitas para melhorar a participação das mulheres no Conselho Gestor, Renata defendeu a necessidade de ampliação da divulgação do fórum, mesmo no período fora das eleições, como forma de mobilização de mães a participarem: "eu faria mais divulgações para com as mulheres, com as mães, para que todas possam participar". Já, sobre a participação das mulheres de uma forma geral na política, Renata acredita ser necessária a apropriação das mulheres na política, dissociadas 
da orientação de homens por detrás de suas participações. Para isso, seria necessária a inserção de mulheres com um passado político, descrito assim: "uma mulher com outra cabeça, uma mulher do povo, uma mulher que convive com o povo, uma mulher que tem uma cabeça mais aberta, que vá governar melhor o nosso país”.

Embora o significado de participação de Renata estava fortemente atrelado ao sentido de participação política partidária, enquanto para as demais consiste na participação e presença junto aos filhos/as, para todas elas, o conceito de participação está ligado ao espaço fora de casa. As atividades exercidas no espaço doméstico (cuidado e administração de tarefas), quando exercidas fora de casa, têm esse componente participativo importante em suas vidas: o contato com outras pessoas, o cuidado com a zeladoria do equipamento público e a comunicação são elementos essenciais da participação.

A maioria delas reivindica maior divulgação do CEU e do Conselho junto às mães e às vizinhas. Quando tecem opiniões sobre a ocupação do espaço, a maioria delas menciona a administração do tempo dedicado aos afazeres domésticos como importante para a atuação: seja por que tiveram a necessidade de readequação da lógica organizativa do lar (dividir com esposo tarefas e/ou adoção de novas rotina distinta de avós e mãe) ou por associar o exercício de funções domésticas às políticas.

\subsubsection{CEU e CG como reconhecimento pessoal e empoderamento das mulheres - "Lá são os cabeças; aqui são os pẽ̃es"}

Nesta seção objetivo explorar na narrativa das mulheres a abordagem da participação como um elemento de reconhecimento pessoal e do empoderamento feminino. Para isso, as perguntas no roteiro de entrevistas visaram desvendar possíveis contribuições que a participação trouxe na vida das mulheres, assim como compreender como elas assimilaram as possíveis contribuições, tanto em suas vidas como na comunidade.

Como já ressaltei anteriormente, no tópico 3.4.4, que trata das motivações das mulheres ao deixarem o espaço privado, espero compreender o resultado dessa saída e ocupação do espaço público para além do que foi dito pelas mulheres nas entrevistas. Importante a compreensão do empoderamento para cada conselheira entrevistada, tanto no espaço do Conselho, no CEU e na sociedade. Boa parte delas menciona as amizades criadas nas participações no CEU, conferindo oportunidade de agregar conhecimento e aprendizagem em um bairro distante do centro, com carências de equipamentos públicos 
de educação, cultura, lazer e esportes. A função do Centro Educacional Unificado é, literalmente, cumprida, já que o espaço concentra e unifica também o reconhecimento e o empoderamento para as moradoras. O interesse por detrás da participação delas nas atividades físicas vai além do mero cuidado com o corpo e a saúde, mas elas também valorizam o diálogo, a troca de conhecimento, a ampliação do círculo de amizade, extrapolando, muitas vezes, para um contato quase familiar com funcionários e usuárias/os do CEU.

A importância do reconhecimento social para as mulheres também foi um ponto abordado, principalmente em um momento de vida que estão excluídas do mercado de trabalho formal, distante dos filhos já crescidos e parentes em uma sociedade que invisibiliza o trabalho pelas quais elas se dedicam: o doméstico. Ou seja, o papel do CEU é de recuperar a autoestima das mulheres alijadas da sociedade. Vale lembrar que o espaço, além de proporcionar uma experimentação da participação política, em uma dimensão menor, proporciona-lhes o conhecimento dos meandros políticos.

Mariana vê como positiva a participação de mulheres e homens no Conselho e não enxerga diferenças entre os sexos na participação, embora perceba que muitos homens não se misturam com as mulheres. A Mariana nota esse comportamento, principalmente, durante suas atividades físicas no CEU. A hipótese da conselheira é de que os homens ficam intimidados devido à presença majoritária de mulheres nos espaços do CEU:

Olha, tem homem não quer se misturar, às vezes, com a mulher não sei se é porque fica envergonhados às vezes de ter mais mulher do que homem. Não sei se é isso. Eu vejo na piscina mesmo, tem pouco homem nadando, na ginástica pouco homem nadando, na caminhada tem pouco homem.

A avaliação que Mariana faz do Conselho Gestor é positiva, destacando ser um espaço organizado, que respeita e ouve a voz das mulheres e nega qualquer existência de discriminação ou outro obstáculo: "o nosso Conselho aqui não tem assim, nem a discriminação nem a baixaria também, assim tudo bem". Contudo, lembra que, eventualmente, as pessoas querem falar um pouco mais e ao mesmo tempo, sendo necessário que seja feita a intervenção de forma mais organizada:

Não às vezes, a gente quer falar um pouco alguma coisa assim e eles, aquela pessoa termina, aí a gente continua, o outro continua, fica aquele negócio eu falo você fala, eu falo você falo ao mesmo tempo, que aí não tem nem a minha e nem a sua, então tem que ser um por vez que é para todo mundo ouvir e entender. 
Mariana acenou positivamente com a cabeça quando interrogada se a experiência da participação no Conselho Gestor do CEU trouxe mudanças em sua vida. A experiência da participação tem sido positiva para Mariana, que enumera alguns retornos. Além de se sentir bem em poder contribuir com outras pessoas, a participação faz com que ela esteja informada dos acontecimentos e ser reconhecida por outras pessoas da comunidade, já que essas costumam chamá-la para conversar: "Olha, alguma coisa fez, porque eu sempre estou a par das coisas, as pessoas se elas têm alguma coisa me chamam pra conversar."

O relato abaixo, de Nair, deixa claro como seu trabalho cultural executado no CEU obteve o reconhecimento social. Ela lamenta que o trabalho desenvolvido, inicialmente, no CEU não tenha sido reconhecido. Revela uma das hipóteses da pesquisa e um dos motivos que levam as mulheres ao espaço do Conselho Gestor: o reconhecimento e a identificação. Nair afirma ter obtido identificação e reconhecimento com o "pessoal" do movimento de cultura, no início do CEU:

Para você ver como a gente conseguiu ter uma identificação com esse pessoal que veio logo no início, tanto que eles sabem os nomes da gente.

Reconhece que a participação no Conselho Gestor lhe creditou amizades no período de atuação. Evidentemente que a experiência do CEU fez alguma diferença na vida de Nair por ter agregado pessoas em seu círculo de amizades e, como ela mesma menciona: "fica muito família, eu vejo a extensão do meu bairro como a minha família”, porque diz gostar de conhecer pessoas: "eu não consigo ver uma pessoa e não abraçar, não beijar, essa coisa de toque".

A proposta estratégica de atração de pessoas ao Centro Educacional, sugerido por Nair, seria a criação de quiosques para a comercialização de alimentos produzidos na própria região e realizados pelas próprias mulheres e moradoras, como experimentado no Sesc. Notei que a mesma conselheira, que se apresenta receptiva a novas amizades, almeja um espaço institucional que ofereça esse encontro de mulheres. Essa proposta que visa dar oportunidade às mulheres da região pode ser entendida como instrumento de empoderamento dessas trabalhadoras do lar:

Por que que não pode fazer uma coisa legal? Por que que funciona no Sesc, por que que não pode funcionar aqui? De uma forma mais simplificada, talvez, mas por que não? Tem mulheres aqui que tem uns pratos, menina, umas comidas, aqui dessa região, sabe? E eu aprendi a fazer várias comidas, aqui. Por que não trazer essa comida, dessa região para cá?

No trecho a seguir, ela atribui ao Conselho o espaço de oportunidade de estabelecer relações com outras pessoas sobre diferentes assuntos. Percebe o Centro Educacional como 
local de aprendizado e que possibilita se relacionar com pessoas de maior nível educacional:

A coisa melhor que tem é você ter um diálogo, eu no meu caso, que tenho pouca cultura, com gente acima da gente, que tem um conhecimento, um diálogo diferente que você aprende também. A gente passa e aprende. Porque se eu começar a viver com pessoas piores do que eu, a tendência é ficar pior.

Ou seja, a aproximação delas do espaço educacional do CEU é atrativo, pois significa acesso a um quadro qualificado de corpo docente que circula pelo local, as aproxima do conhecimento em um local distante do centro, e, portanto, da concentração de oportunidades. É esse mesmo conhecimento que as conselheiras desejam absorver, e é por elas valorizado ao longo da entrevista.

Além da busca por agregar conhecimento, percebi na fala de Mariana a necessidade de se relacionar com outras pessoas com nível educacional e formativo maior do que o seu, como forma de aprendizagem. Mariana reconhece a importância do interlocutor como responsável por agregar conhecimento e conferir qualidade dialógica, imbricado no processo de aprendizagem:

Porque se você continua sempre com gente que tem um diálogo diferente, uma conversa totalmente diferente, você está aprendendo, muito ou pouco você aprende, porque você começa a desenvolver sua mente. Eu conversei com fulano, fulano falou isso e isso. Não é a gente que, a gente sozinha não consegue se desenvolver sozinho, você tem que que ter diálogo com as pessoas.

Assim como Mariana, a estratégia de aproximação de Nair junto ao CEU teve como objetivo o acesso ao quadro de docentes, e não, necessariamente, à participação nas ações do Grupo da Comissão da Verdade, do Centro de Educação em Direitos Humanos do CEU, em 2014 como principal objetivo:

E o meu foco nunca foi falar com o pessoal mesmo do... mas era acessar os professores daqui, porque eu entendia que tudo tinha que começar por aqui. Lógico o que eles traziam, era muito bom tudo mas foi aí que onde eu me deparei muito com a questão aqui dos CEUs.

Antes, porém, de analisar o relato das outras mulheres na compreensão do reconhecimento e empoderamento por meio da participação no CEU e no Conselho Gestor, é importante observar a desconstrução de paradigmas acerca da participação no Conselho vivida por Mercedes. Ela percebe que sua participação no Conselho desconstruiu uma visão distante e inacessível do conceito de gestão, tendo em vista que, anteriormente, a sala do Conselho Gestor do CEU ocupava o andar superior do prédio. Os "cabeças", constituídos 
por pessoas qualificadas e com formação e, notadamente, que fazem parte da gestão, e o grupo dos "peões", referindo-se aos trabalhadores braçais, de menor importância. Com a mudança da localização da sala, sua participação e interação junto à gestão foi desmistificada:

Às vezes as pessoas acham um bicho de sete. Que nem, antes, a sala do Conselho Gestor era lá no quinto andar, então a gente tinha pouco acesso. Sempre todos tiveram a liberdade de chegar, só que, por ser lá em cima, ficou um negócio bem, tipo assim, "lá são os cabeças; aqui são os peões". Quando tiveram a ideia de descer, tudo ficou mais próximo.

Renata defende a incorporação da comunidade no debate de interesses da população. Entende a política como espaço da participação popular no debate e fiscalização das ações, nas diferentes esferas de atuação:

Então, política, para mim, era o povo estar brigando pelo que é seu na prefeitura, no Estado. Que nem, agora, houve o corte da educação, ir lá cobrar: 'Por que você cortou?' Não, não é, isso é para justificar. Entendeu?

A ideia de participação popular não está vinculada somente com a ideia de fiscalização, porém com a ideia de publicidade, a fim de que as pessoas se apropriem do espaço público. Do espaço da internet, como, por exemplo, a televisiva e rádio, de forma a não excluir a população sem acesso à internet ou até mesmo à população idosa, que tem maior dificuldade de manusear aparelhos tecnológicos. Embora seja a conselheira mais jovem dentre as entrevistadas, seu entendimento de política, além de perpassar a inclusão popular de atuação nas três esferas, também volta sua atenção à inclusão da população idosa e sem acesso à tecnologia. Ou seja, uma participação política caracterizada pelo recorte etário e de renda:

Então, eu acho que o povo tinha que fiscalizar mais, vir em público, não colocar no site. Tem muita gente que não tem conhecimento, ele é povo igual a mim, igual a você, igual a todo mundo, tem que vir nos aparelhos de televisão, nos rádios, colocar, distribuir, sabe, nas áreas mais humildes, aonde, talvez, não tenham acesso, as pessoas de mais idade. As pessoas de mais idade, não que eu quero, mas não sabem mexer em um tablet, em um celular.

Especificamente, o espaço do Conselho adquire esse sentido de ritual e propicia à dona de casa um importante contato com a esfera pública de participação social. A entrevistada Renata transmite a ideia de que o espaço a fez mais interessada pelo universo político, agregando conhecimento do vocabulário, no conhecimento das ordens de tramitações de leis e a função de vereança: 
Eu me envolvi mais com o negócio de política, me interessei mais, saber a função de um vereador, de um deputado, de quem era o fiscal de quem, quem aprovava o quê, quem mandava as leis para onde, quem podia barrar o presidente, quem podia, sabe? Então, isso me ajudou a ter um pouquinho mais. Eu acho que eu nunca sei tudo, mas um pouquinho mais. Porque antes eu não sabia a função de um vereador, quer dizer, ele é fiscal, eu achava que ele resolvia, mas ele é fiscal, ele vai lá, manda as suas ideias. Então, hoje, eu acho que tinha que ter mais é vereadoras, porque mulher é que é boa para fiscalizar, para falar, para ter boca para falar. Entendeu?

Além de tornar mais acessível a participação popular das pessoas de mais idade na política e do reconhecimento da sua limitação no manuseio tecnológico, Renata reivindica o entendimento de uma política que inclua e mantenha as mulheres no espaço público. Para isso, ela faz menção à necessidade da cota de candidaturas de mulheres na política. Sua justificativa para a adoção de cota se baseia na noção de dominação masculina do sistema político. Quando as mulheres alcançam tal espaço o fazem por intermédio de homens:

Lógico que eu não vou metralhar a política, mas eu acho que o povo precisaria acordar mais em relação à política. Acho que as mulheres deveriam ficar mais no poder, sabe? Eu acho que parece que tem uma cota restrita e as mulheres que estão lá foram colocadas por seus políticos, seus pais, por seus maridos, por seus filhos.

Quando interrogada sobre quais ações devam ser feitas para aperfeiçoar a participação política das mulheres, a partir a experiência no CEU, Renata entende que as mulheres precisam se apropriar da política, criando menos dependência com os homens. Ainda, segundo a conselheira, a política predominantemente masculina tem caráter pejorativo, com o objetivo de satisfazer os interesses pessoais, denominada por Renata como "politicagem":

Então, eu acho que tinha que ter mais mulheres no poder. Mulheres esclarecidas, uma mulher com outra cabeça, uma mulher do povo, uma mulher que convive com o povo, uma mulher que tem uma cabeça mais aberta, que vá governar melhor o nosso país.

Quando indagada se a conselheira recomendaria a outras mulheres para participarem do Conselho Gestor, Renata disse que "convidou bastante gente" para se candidatar às eleições do Conselho, contudo as negativas foram muitas com a justificativa de que participar do Conselho é fazer "política".

Não aceitaram. Nos nossos grupos das atividades a gente fez vários convites, de reuniões, eu convido. Mesmo vocês não sendo os inscritos deveriam participar, mas nada. 
Sobre o aperfeiçoamento da participação das mulheres, Renata acredita ser necessária a ampliação da divulgação da importância do Conselho Gestor. É esse o públicoalvo a ser atraído para o colegiado, por serem as mulheres mais ativas em comparação aos homens.

A conselheira Renata voltaria a participar do colegiado novamente e acredita que a participação das mulheres no Conselho Gestor é uma oportunidade para elas estarem no espaço público. E completa que recomendaria a participação a outras mulheres:

Ah, com certeza. Com certeza. Até por conhecimento delas, para sair, algumas, não todas, para o mundo, sabe? Para você ampliar mais. Sim, eu convidaria.

A recomendação da conselheira a outras mulheres é a ampliação e o envolvimento delas nas atividades do CEU, para obterem o conhecimento e se acostumarem com o espaço participativo, e assim alçarem voo no espaço político. Espera que a atuação no Conselho Gestor possa ampliar o poder de decisão junto à Prefeitura, tanto que para isso sugere a presença de uma representação do poder público municipal durante as reuniões, de forma a dirimir questionamentos, principalmente, sobre a burocracia financeira do município, e assim, levar demandas da população ao executivo municipal:

Eu espero que a gente consiga ter mais poder de decisões junto com a política, junto com a prefeitura. Eu acho que deveria haver um representante da prefeitura, porque a gente esbarra sempre na burocracia do dinheiro, sabe? Vontade de fazer o Conselho tem, vontade de resolver o problema do equipamento. Porque o Conselho Gestor, na escola, ele resolve problema do equipamento. Ter sempre um representante da prefeitura junto com a gente, para estar debatendo as coisas, para estar levando as nossas ideias, estar levando os nossos problemas, sabe? Eu acho que isso seria muito importante.

O enfrentamento feito por Mercedes diante dos abusos de poder da gestão difere da estratégia de Nair, que optou por se retirar do colegiado. Percebi que, ao contrário de Nair, Mercedes resiste no incentivo a novos participantes:

A Renata através de mim começou a participar; através da Renata, ela já indicou um casal que está participando, que entrou agora, que são pais de uma amiga nossa, da Léia, que ela é corredora aqui, ela treina corrida e tudo. Então, agora que está se formando um Conselho e essas pessoas, eu acho legal, porque elas nunca participaram; então, a partir daí a Renata já está alerta; e tem muita coisa que eu falo, "Renata, você tem que ter sua opinião própria; só que você fica alerta."

O convite de Mercedes é direcionado, especialmente, às mulheres, pois ela entende que o obstáculo de participação dos homens no CEU é o exercício do trabalho remunerado fora de casa. As mulheres conseguem ajustar suas atividades aos horários das reuniões, que 
ocorrem em expediente de trabalho: "porque os homens geralmente não... tem às vezes... são durante o dia." No comparativo da participação de gênero, reconhece que os homens não gostam de estar no espaço, ao tomar de exemplo seu esposo: "Meu marido mesmo, agora que ele se aposentou, está em casa, mas ele não tem... ele não gosta, ele não".

A dona de casa e conselheira Mercedes acredita também que sua atuação fez a diferença, percebe a necessidade de divulgação do equipamento e a oferta de seus serviços junto à comunidade. Ainda existem pessoas "do outro lado da linha" do trem que ainda desconhecem a existência do CEU como espaço para além da escola:

Porque o CEU é da comunidade e eu vivo, eu chamo muita gente. Tem pessoas, os meninos mesmo, o Pedro, que é coordenador de esporte, andou fazendo umas panfletagens por aí e o Mateus. Eles conversaram com muita gente do lado de lá da linha. Tem pessoas que não sabem o que que tem aqui dentro, que pode fazer uma ginástica, pode fazer uma caminhada, pode vir a hora que quer. Tem gente que acha que é só uma escola. Como também, e eu falo, às vezes, em algumas reuniões.

Lilian vê como necessária a ampliação do convite à comunidade. Recomenda que outras mulheres participem da instância participativa, tendo em vista a experiência benéfica em sua saúde. A melhora na saúde possibilitou seu empoderamento e autonomia:

Ia falar para elas acordarem para vida porque isso aqui é nosso, isso tem que melhorar. Eu custei tanto, trabalhei tanto para o CEU vir para cá, eu melhorei de saúde. Você sabe que eu tenho esclerose múltipla, perdi tudo. Perdi tato, coordenação, sensibilidade, tudo. Quando eu me ocupei desse negócio, que eu tinha um negócio para fazer, eu me vi com meu filho... Menina, parece que você acorda, sabe, tudo melhorou, o problema está aqui. Hoje eu ando, eu vou para qualquer lugar, eu faço tudo que tem para fazer, eu acho que eu sou uma pessoa ativa, dentro das minhas limitações eu faço.

A preocupação de Mercedes é a autonomia de opinião dos participantes frente às manipulações que possam existir no colegiado: "porque tem muita gente que gosta de manipular as pessoas". Ao término de sua fala, Mercedes faz crítica a uma postura passiva dos participantes no colegiado, sugerindo a possibilidade de que isso aconteça:

Entendeu? Você tem, a gente tem que ter opinião própria, porque não adianta você formar um Conselho, e o Conselho para tudo dizer "amém". É isso que eu sou contra constantemente.

Sua expectativa de participação no Conselho é a melhora da situação coletiva: "Eu espero que sempre melhore para gente, para a comunidade, é. Porque aqui é o nosso bairro, a gente também tem que". Embora tenha se beneficiado pessoalmente de participar das atividades do CEU, chama atenção também para a importância da participação para o bem coletivo, para a "comunidade" e ao "bairro". 
Considerando o empoderamento feminino como o ato de conceder o poder de participação social às mulheres, garantindo a elas estar cientes sobre a luta pelos seus direitos, eu poderia apressadamente afirmar que o processo de empoderamento deste grupo de integrantes do Conselho Gestor do CEU foi parcial, uma vez que muitas das decisões já vêm prontas, como as pautas das reuniões. Contudo, tomando por base os Princípios de Empoderamento das Mulheres' (WEPs), publicação elaborada pela ONU Mulheres (Entidade das Organização das Nações Unidas para a Igualdade de Gênero e Empoderamento das Mulheres) e pelo Pacto Global das Nações Unidas (2010), posso afirmar que a participação no Conselho Gestor fomenta a capacidade de liderança comunitária dessas mulheres (ONU MULHERES, 2010). A participação faz com que percebam a importância do respeito aos direitos humanos, a garantia de não discriminação de homens e mulheres, no espaço doméstico, mas também no próprio Conselho Gestor. Elas também adquirem e/ou reforçam a consciência de que a educação e a formação podem propiciar desenvolvimento pessoal e coletivo para as mulheres, assim como espaços de atendimento público, como o $\mathrm{CEU}$, poderiam incentivar de modo mais amplo as práticas da cadeia de abastecimento e economia informal. 


\section{CONSIDERAÇÕES FINAIS}

A fim de entender o significado de participação para as conselheiras, foi-me necessário compreender as trajetórias de vida e o cotidiano das mulheres moradoras do entorno do CEU. Por se tratar de um grupo predominantemente de mulheres com características em comum - pertencentes ao setor popular, moradoras da periferia, de elevada faixa etária e que exerceram atividade remunerada fora de casa no passado - o sentido da participação tem um significado particular. Embora algumas delas começaram a participar do CEU com o intuito de buscar melhores condições educacionais aos seus filhos, a maioria encontra uma brecha de inserção nas atividades esportivas do CEU. A saída do espaço doméstico, representado pela incessante rotina cotidiana, acontece motivada pelo cuidado à saúde, corpo e mente. A participação nas atividades de ginástica oferecidas no espaço público representa essa oportunidade de cuidado de si, em um momento da vida cujo trabalho fora de casa não faz parte do cotidiano das mulheres. Após anos de trabalho fora de casa, de cuidado dos outros, a participação no Conselho Gestor representa o apogeu de suas vidas: é no espaço do Conselho que as mulheres retomam a visibilidade social que o trabalho doméstico nega. É no espaço fora de casa que elas se sentem realizadas e úteis, socialmente, diante da incessante rotina de trabalho doméstico.

Gohn (2004, p. 24), chama atenção para o novo processo de "empoderamento" que tem ocorrido junto à comunidade, cuja nova terminologia tem sido incorporada na linguagem das políticas públicas.

Não podemos perder de vista que essas novas redes associativistas também estão contribuindo para o empowerment (empoderamento) dos setores populares em nossa sociedade, ainda que de forma muito pontual por trabalharem com projetos focalizados e tratarem os demandatários excluídos como clientes de serviços sociais. (GOHN, 2004, p. 25)

O sentido de empoderamento é a capacidade de liderança comunitária das mulheres, liderança é essa que em algum momento de suas vidas se perdeu pela ação do patriarcado. Os relatos de Nair denotam essa afirmação, pois sua criação, desde pequena, deu-se no seio da comunidade, entre vizinhos e os mais velhos. O empoderamento experimentado por Nair em um momento da vida de mais idade, nos espaços participativos, significa a retomada dessa exitosa experiência de liderança que foi vivenciada nas ruas com os mais velhos, em sua infância. Faz certo sentido o tom reivindicatório que pautou as falas das conselheiras, expostas ao longo do capítulo três, o que representa justamente a reivindicação desse sentimento comunitário de valorização de vivência com os mais velhos. É como se esse 
espaço participativo das mulheres conselheiras do CEU rememorasse uma parte de suas vivências que conferiram aprendizado e experiência, e que, novamente, lhes é experimentado. A importância que as conselheiras-mães conferem às brincadeiras nas ruas e à presença aos mais velhos se justifica porque lhes foi ensinada a valorizarem e desejam reproduzir a experiência junto a seus filhos e netos.

Justamente por isso que Gohn (2004), ao tratar da participação nos Conselhos entende que essa forma participativa, que leva em conta "a experiência de cada cidadão", deve considerar o aprendizado e o que está sedimentado na memória dos atores sociais. Portanto, ela rechaça uma participação pragmatista, ancoradas meramente em índices estatísticos e lucro, já que esse modelo não produz experiência, somente imediatismo.

Gohn (2004) acredita que o exercício da atividade política na esfera pública promove uma cultura política pública, cuja organização dos cidadãos garante a fiscalização do poder público. A partir de uma orientação ética e pautada pelo respeito ao próximo, os interesses diversos são reconhecidos e negociados no espaço, ao contrário da tradição autoritária e das práticas clientelistas de oligarcas, privatistas e patrimonialistas. (GOHN, 2004) Isso pode ser contextualizado no caso dos Conselhos Gestores dos CEUs, importantes para a compreensão do caráter educativo do Conselho e do seu papel no empoderamento das participantes. Mesmo que os Conselhos Gestores dos CEUs ainda se estruturem legalmente, em uma relação clientelista com o Estado, não deixa de ter importância a função dos Conselhos Gestores na comunidade e o aspecto de empoderamento para as participantes.

O tom reivindicatório na fala de Nair, por exemplo, revela que as mulheres conhecem perfeitamente que o CEU não deveria se limitar a rigidez do espaço escolar: “[...] não é só escola, isso daqui não é só escola, isso daqui é um Centro Educacional, mas o direito que os seus alunos têm, eu também tenho, como usuária, como aluna”. E como mulheres de mais idade, que participaram do período que antecedeu a inauguração do equipamento público, elas são conhecedoras do projeto original do CEU e, sabiamente, constroem uma percepção, clareza e capacidade de análise dos meandros participativos. A conselheira Nair reconhece que a gestão do CEU limita a participação do usuário, o que leva a ser um local de disputas, e como estratégia de "sobrevivência" do espaço participativo ela recorre à inserção da filha no conselho para que possa ser ouvida. Tratase de um espaço educacional unificado que ao mesmo tempo em que as mulheres se empoderam nele, também limita o empoderamento, pois a gestão não consegue ouvi-las e compreendê-las, já que para ser ouvida a conselheira precisa ter a credencial do diploma. 
Trata-se de um ambiente educacional unificado que deveria contemplar as demandas dos diferentes segmentos sociais participantes que ali chegam. Como foi possível observar nas entrevistas, o CEU é um espaço de disputa. Não somente um espaço de disputas de pautas a serem debatidas no colegiado, mas também entre quem pode falar, quem pode ser ouvido, quem pode entrar e circular no espaço.

O espaço do Conselho representa a oportunidade da troca de conhecimento, diálogo e aprendizagem com outras pessoas, cujo exercício da escuta e da fala, importantes instrumentos no espaço público, estão em exercício. Se o espaço doméstico para as mulheres de mais idade representa o isolamento social e a solidão, as atividades no CEU e a atuação no Conselho Gestor significam um oposto, certa liberdade. Deve-se considerar que a maioria das mulheres conselheiras se encontram em uma fase da vida com os filhos criados e distantes do seu convívio diário. Todos esses elementos colaboram para a compreensão do sentido de participação para as mulheres do Conselho Gestor do CEU.

Não é por um acaso que para as conselheiras, a participação é caracterizada junto aos filhos e filhas; de proximidade e contato com outras pessoas; de cuidado e zeladoria do equipamento público; e com destaque para o aspecto comunicativo. Essas características permearam praticamente todas as falas de atuação das mulheres no espaço público e passam pela noção de empoderamento feminino, fruto da participação de suas experiências profissionais e domésticas.

Devido à intensidade da relação que as conselheiras mantêm com os filhos e filhas, a atuação das mães no Conselho Gestor pode refletir e influenciar positivamente os filhos e filhas, que passam a enxergar que é possível também acessar a outro universo experimentado pelas mães para além do espaço doméstico. É bastante simbólico o impacto, especialmente, nas filhas, de se espelharem em suas mães atuantes no espaço público, seja no cuidado da saúde, na atuação comunitária, no estabelecimento de laços de solidariedade e de amizades junto à comunidade.

O sentido do empoderamento para as mulheres é porque a participação no CEU e no Conselho Gestor, além de conferir uma ampla rede de relações sociais, fazer amizades, proporciona atualização na formação educativa para as mulheres que deixaram de estudar há algum tempo. Além de agregar conhecimento do conteúdo dos temas debatidos no espaço, a participação no Conselho promove o aprendizado de saber ouvir e falar, que não são triviais no processo democrático. Freire trata da importância da escuta na prática docente: “ouvir meninos e meninas, sociedade de bairro, pais, mães, diretoras, delegados de ensino, professoras, supervisoras, comunidade científica, zeladoras, merendeiras etc." 
(FREIRE, 2001, p. 35) Embora as mulheres tivessem alegado não ser necessário nenhum tipo de formação e/ou habilidade para participar da reunião, ainda assim é necessário talento e habilidade interpessoal, além do aprendizado de escuta, conforme destacado por Mariana: "E nem só no Conselho, em qualquer lugar que você vai participar de qualquer reunião, um diálogo que você tem, primeiro você tem que ouvir pra entender pra depois você falar."

No entanto, devo reiterar que para essa consideração final me apoiei na plena definição de empoderamento de Nelly Stromquist (1997), que considera a inclusão de quatro componentes: os parâmetros cognitivos (compreensão crítica das mulheres sobre sua condição de subordinação), psicológicos (sentimento de autoestima), políticos (consciência das desigualdades sociais e de poder e capacidade de organização e mobilização) e econômicos (capacidade de geração de renda independente). Como assinala Stromquist, o componente psicológico é importante, mas é necessário que esteja atrelado ao reforço em investimentos econômicos.

Portanto, além do convívio no CEU, que contribui para a autoestima nas mulheres, a experiência de inserção em atividade produtiva, confere à maioria delas algum nível de autonomia financeira. Dessa maneira, os outros dois parâmetros complementares da definição de empoderamento, segundo Stromquist (1997), é a habilidade das mulheres de ter uma visão crítica de mundo e a consciência da necessidade de rompimento da subordinação patriarcal.

Stromquist (1997), observa que o empoderamento tende a estar dirigido a mulheres que percebem baixos rendimentos, pois é nesse grupo que elas estão mais vulneráveis a comportamentos autoritários de maridos dentro de casa, condição essa que mantém as relações desiguais de gênero. Para efeito deste assunto, destaco o trecho:

Um pré-requisito para o empoderamento, portanto, é sair de casa e participar de alguma forma de empreendimento coletivo que possa ter sucesso e, dessa maneira, desenvolver um senso de independência e competência entre as mulheres. A criação de um grupo pequeno e coeso, onde haja uma estreita identificação entre os membros, é fundamental. Como essas associações são pequenas e de natureza voluntária, muitos membros ganham valiosas experiências e confiança para a liderança por meio das atividades que realizam. A atividade principal do grupo pode variar; podem ser atividades de alfabetização, geração de renda, apoio mútuo para necessidades básicas, etc. Qualquer que seja o objetivo, a atividade do grupo deve ser concebida de forma que o seu processo e a conquista da meta fomentem o desenvolvimento de um sentido de autoestima, competência e autonomia. (STROMQUIST, 1997, p. 83) (Tradução nossa) 
Chama atenção a predominância de mulheres nos Conselhos Gestores. E, para essa análise, vale destacar a pesquisa realizada por Lígia Helena Hahn Lüchmann, Carla Almeida e Éder Rodrigo Gimenes (2017) que trata o perfil de participantes dos Conselhos Gestores. Os autores percebem que o predomínio da participação de mulheres no Conselho Gestor não somente se atribui, porque este espaço seria "mais favorável às mulheres do que a intermediada por partidos políticos", mas porque os conselhos tendem a serem institucionalizados nas áreas sociais, tradicionalmente de predomínio de mulheres. (ALMEIDA; LÜCHMANN; GIMENES, 2017, p. 790)

Essa interpretação de que os Conselhos seriam espaços mais favoráveis à participação das mulheres revela um paradoxo, a meu ver. Ainda que os Conselhos representem um espaço relevante de participação social, tendo em vista sua importância no processo de redemocratização no país, eles são vistos como de menor relevância quando comparados aos partidos políticos. Enquanto a política partidária é predominantemente formada pelos homens, as mulheres são relegadas aos Conselhos, de menor importância na escala hierárquica social, justamente pelo seu forte caráter feminino. Não é por um acaso que os Conselhos das áreas assistenciais da educação, saúde e moradia se multiplicaram no período pós-1988, ao passo que os homens se engajaram na política profissional. Considerando que os espaços participativos valorizados socialmente seriam aqueles de maior competitividade, ainda assim associados a uma característica tipicamente masculina. Em comparação aos Conselhos, os partidos políticos possuem maior visibilidade social, além de serem dotados de recursos financeiros do Fundo Partidário ${ }^{12}$. Outro paradoxo que observei: mesmo sendo menos valorativos, o Conselho Gestor possui relevância na vida das mulheres frequentadoras do CEU.

Segundo os autores, (ALMEIDA; LÜCHMANN; GIMENES, 2017), a presença de mulheres nos Conselhos Gestores de políticas públicas é um indicador importante justamente porque os Conselhos Gestores representam uma conquista de participação da sociedade civil, no processo redemocrático brasileiro. A importância dos Conselhos Gestores se deve porque eles conseguiram absorver um número maior de mulheres apesar da subrepresentação feminina nas disputas políticas eleitorais.

Não que os Conselhos não exijam conhecimento e habilidades, segundo esses autores, mas são “menos exigentes no que se refere à disponibilidade de tempo, de recursos

\footnotetext{
${ }^{12}$ O Fundo Especial de Assistência Financeira aos Partidos Políticos, denominado Fundo Partidário, é constituído por dotações orçamentárias da União, multas, penalidades, doações e outros recursos financeiros que lhes forem atribuídos por lei. (cf. TSE)
} 
financeiros, de articulações, negociações e de disputa de poder”. Ao contrário, da participação nos partidos políticos, que exige "visibilidade, o discurso público e midiático, a formação de alianças e o enfrentamento com hostilidades que estão ancoradas em discursos poderosos de encobrimento do emocional - apontado como de domínio feminino - frente ao racional - lido como fundamento do mundo masculino" (ALMEIDA; LÜCHMANN; GIMENES, 2014, p. 791). Como observei, o exercício do cargo de conselheiro/a no CEU não demanda nenhuma exigência legal, além da disposição de tempo de participação.

Desde que a pesquisa foi pensada, objetivei debruçar-me para saber como a participação no CEU influencia a vida das mulheres conselheiras, que acumulam várias jornadas de afazeres domésticos, estudos, cuidado com os filhos e o marido, principalmente ao considerar as desigualdades sociais e de gênero vivenciadas pelas mulheres periféricas. A partir dos depoimentos das participantes do Conselho Gestor do CEU, foi possível a compreensão do significado de atuação das conselheiras. Inicialmente, acreditei que o significado de participação reconhecido pelas conselheiras estava atrelado, unicamente, ao sentido da participação política. No decorrer da pesquisa, foi necessário me despojar das pré-noções na compreensão das subjetividades dos relatos das mulheres, a leitura e a interpretação das entrevistas para captar as realidades, vivências e visões de mundo, até para quebra de estereótipos e senso comum.

O referencial teórico junto com o trabalho de campo ofereceu-me algumas pistas na compreensão da interpretação da participação das mulheres no Conselho Gestor do CEU. A partir do mapeamento da pesquisa, concluí que o caráter de deliberativo do Conselho é pouco ou quase nada, tendo em vista que as pautas chegam prontas ao colegiado, sugerindo que o momento de reunião representa um espaço de relações entre mulheres, socialização de informes, para a ciência das participantes sobre os acontecimentos na comunidade escolar.

Frente ao que foi abordado, a hipótese aventada na pesquisa é de que a participação no Conselho Gestor do CEU se reverta no empoderamento para as mulheres. Mesmo que esse empoderamento não passe pelo grau de decisão tomado no Conselho, mas tenha a ver com a dimensão educativa da participação em espaços para além do universo doméstico, exigindo, portanto, a aquisição de habilidades para o debate de pautas públicas, ainda que não sejam as grandes pautas. Para as mulheres conselheiras, sair de casa e participar do CEU e do Conselho Gestor é suficiente para elas crescerem. 
Partindo da premissa da existência de uma carência na literatura e em estudos sobre a participação das mulheres nos espaços dos Conselhos Gestores, até como forma de eliminar a invisibilidade das mulheres periféricas e refletir sobre as consequências que a participação proporcionam na vida das mulheres, estou certa de que o presente estudo é oportuno também para contribuir na estruturação de elementos que possam ampliar a discussão das políticas públicas educacionais, de gênero e de participação social. 



\section{REFERÊNCIAS}

ABERS, Rebecca Neaera; KECK, Margaret Elizabeth. Representando a diversidade: Estado, sociedade e 'relações fecundas' nos conselhos gestores. Caderno CRH, Salvador, v. 21, n. 52, p. 99-112, jan./abr. 2008.

ABÍLIO, Ludmila Costhek. Sem maquiagem: o trabalho de um milhão de revendedoras de cosméticos. São Paulo: Boitempo, 2014.

ARAÚJO, Gilza. Entrevista com Margarida Genevois. Portal Educação em Direitos Humanos, 2015. Disponível em: <http://portaledh.educapx.com/noticias/entrevista-commargarida-genevois1439223420.html>. Acesso em: 18 dez. 2019.

ARROJO, Rosely Fátima dos Santos. Formação de educadores para o programa Centro Educacional Unificado (CEU) na cidade de São Paulo. 2015. 85 f. Dissertação (Mestrado) - Curso de Educação, Educação, Pontifícia Universidade Católica de São Paulo, São Paulo, 2015. Disponível em: <https://tede2.pucsp.br/handle/handle/10263>. Acesso em: 23 set. 2019.

AVRITZER, Leonardo. Instituições participativas e desenho institucional: algumas considerações sobre a variação da participação no Brasil democrático. Revista Opinião Pública, v. 14, n. 1, p. 44-64, 2008.

BRABO, Tânia Suely Antonelli Marcelino. Gênero e poder local. São Paulo: Humanitas, 2008.

BRUSCHINI, Cristina. Apresentação. In: BRUSCHINI, Cristina; ARDAILLON, Danielle; UNBEHAUM, Sandra G. Tesauro para estudos de gênero e sobre mulheres. São Paulo: Fundação Carlos Chagas/ed. 34, 1998, 304 p.

. Trabalho doméstico: inatividade econômica ou trabalho não-remunerado?

Revista Brasileira de Estudos de População. São Paulo, v. 23, n. 2, p. 331-353, jul./dez. 2006.

BUTLER, Judith. Problemas de Gênero - Feminismo e subversão da identidade. Rio de Janeiro: Civilização brasileira, 2003.

. Performatividad, precariedad y políticas sexuales. Revista de Antropología

Iberoamericana, Madrid, v. 4, n. 3, sep./dec. 2009, p. 321-336. Disponível em:

$<$ http://www.redalyc.org/pdf/623/62312914003.pdf>. Acesso em: 22 ago. 2019.

BRASIL. Ministério da Educação. Secretaria de Educação Especial. Política Nacional de Educação Especial na Perspectiva da Educação Inclusiva. Brasília: MEC/SEESP, 2007. Disponível em:

$<$ http://portal.mec.gov.br/index.php?option=com_docman\&view=download\&alias $=1669$ 0 -politica-nacional-de-educacao-especial-na-perspectiva-da-educacao-inclusiva05122014\&Itemid=30192> Acesso em: 07 set. 2019. 
BRASIL. Lei $n^{\circ}$ 8.142, de 28 de dezembro de 1990. Dispõe sobre a participação da comunidade na gestão do Sistema Único de Saúde (SUS) e sobre as transferências intergovernamentais de recursos financeiros na área da saúde e dá outras providências.

. Lei $\mathrm{n}^{\circ}$ 9.394, de 20 de dezembro de 1996. Estabelece as diretrizes e bases da educação nacional.

.Presidência da República. Secretaria Especial de Políticas para as Mulheres. II Plano Nacional de Políticas para as Mulheres. 2. reimp. Brasília, DF, 2008. Disponível em: <http://www.spm.gov.br/assuntos/pnpm/livro-ii-pnpm-completo09.09.2009.pdf $>$ Acesso em: 15 set. 2017.

BRUSCHINI, Cristina. Trabalho doméstico: inatividade econômica ou trabalho nãoremunerado? Revista Brasileira de Estudos de População. São Paulo, v. 23, n. 2, p. 331-353, Dec. 2006. Disponível em:

$<$ http://www.scielo.br/scielo.php?script=sci_arttext\&pid=S0102-

30982006000200009\&lng=en\&nrm=iso >. Acesso em: 19 out. 2019. Doi:

$<$ http://dx.doi.org/10.1590/S0102-30982006000200009>.

CALDEIRA, Teresa Pires do Rio. A política dos outros: o cotidiano dos moradores da periferia e o que pensam do poder e dos poderosos. São Paulo: Brasiliense, 1984, 300 p.

. Mujeres, Cotidianidad, y Politica. In: JELIN, Elizabeth (ed). Ciudadania a

Identidad: las mujeres en los movimientos sociales latino-americanos. Geneva:

UNRISD, 1987.

Gênero continua a ser o campo de batalhas: juventude, produção cultural e a reinvenção do espaço público em São Paulo. Trad. Saulo Adriano. Revista USP, São Paulo, n. 102, p. 83-100, jun./ago. 2014.

CARVALHO, Ricardo. Seminário Nacional dos CEUs. Estação Cidadania, 2014. Disponível em: $<$ http://estacao.cultura.gov.br/2014/01/21/seminario-nacional/>. Acesso em: 07 jun. 2018.

NOVOS CEUs serão construídos a partir do próximo ano. Cidade de São Paulo, 2014. Disponível em:

$<$ https://www.prefeitura.sp.gov.br/cidade/secretarias/obras/empreendimentos/unidades_d a_educacao/index.php?p=181674>. Acesso em: 26 ago. 2018.

CONNELL, Raewyn; PEARSE, Rebecca. Gênero: uma perspectiva global. Tradução da 3. ed e revisão técnica de Marília Moschkovich. São Paulo: Versos, 2015.

CANGUSSU, Lílian Cristina Pereira. Centros Educacionais Unificados de São

Paulo: implementação e continuidade numa nova gestão política. 2010. $112 \mathrm{f}$.

Dissertação (Mestrado) - Curso de Educação, Faculdade de Humanidades e Direito, Universidade Metodista de São Paulo, São Bernardo do Campo, 2010. Disponível em: $<$ http://tede.metodista.br/jspui/bitstream/tede/1180/1/Lilian\%20Cangussu.pdf $>$. Acesso em: 17 set. 2019. 
CAVALEIRO, Maria Cristina. Feminilidades homossexuais no ambiente escolar: ocultamentos e discriminações vividas por garotas. 2009. Tese (Doutorado em Educação) - Faculdade de Educação, Universidade de São Paulo, São Paulo.

CÔRTES, Soraya Vargas. Viabilizando a participação em conselhos de políticas públicas municipais: arcabouço institucional, organização do movimento popular e policy communities. In: HOCHMAN, Gilberto; ARRETCHE, Marta; MARQUES, Eduardo. (orgs.). Políticas públicas no Brasil. Rio de Janeiro: Fiocruz, 2007. P. 125-144.

DAMATTA, Roberto. A casa \& a rua: espaço, cidadania, mulher e morte no Brasil. Rio de Janeiro, Guanabara, 5. ed., 1997, 123 p.

DELPHY, Cristine. Patriarcado (teorias do). In HIRATA, Helena et al.(orgs). Dicionário crítico do feminismo. São Paulo: Unesp, 2009, p. 173-179.

INFRAESTRUTURA urbana e obras gabinete do secretário. Diário Oficial da Cidade de São Paulo, 2015. Disponível em:

$<$ https://www.prefeitura.sp.gov.br/cidade/secretarias/upload/infraestrutura/arquivos/Fotos /CEUS/abertura_licitacao_proposta_comercial_ceus_26_06_2015_doc.pdf $>$. Acesso em: 26 ago. 2018.

DIEESE. Anuário das mulheres brasileiras. São Paulo: Dieese, 2011a. . O Conselho dos centros de educação profissional da Bahia: Caderno do

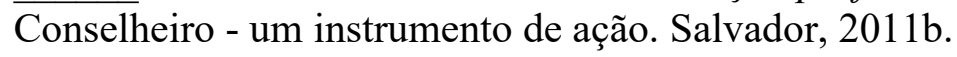

. Metodologia para mapeamento da demanda de educação profissional na Bahia. Salvador: Dieese, 2012. 2014.

. Educação Profissional da Bahia: geração, gênero e etnia. Salvador: Dieese,

DORIA, Og Roberto; PEREZ, Maria Aparecida (org.). Educação, CEU e cidade: breve história da educação pública brasileira nos 450 anos da Cidade de São Paulo. São Paulo: Secretaria Municipal de Educação da Cidade de São Paulo e Porto Alegre: Livraria do arquiteto FA-UFRGS, 2007.

FIGLIOLINO, Simone Aparecida Preciozo. Centro Educacional Unificado (CEU): concepções sobre uma experiência. 2014. 194 f. Dissertação (Mestrado) - Curso de Educação, Educação, Pontifícia Universidade Católica de São Paulo, São Paulo, 2014. Disponível em:

$<$ https://tede2.pucsp.br/bitstream/handle/9819/1/Simone\%20Aparecida\%20Preciozo $\% 20$ Figliolino.pdf $>$. Acesso em: 28 set. 2019.

FONSECA, Claudia. Família, fofoca e honra. 2. ed. Porto Alegre: UFRGS, 2004.

FONTOURA, Natália; ARAÚJO, Clara. (Eds.). Uso do tempo e gênero. Rio de Janeiro: UERJ, 2016. 
FOUGEYROLLAS-SCHWEBEL, Dominique. In: HIRATA, Helena. et al. Dicionário crítico do feminismo. São Paulo: Unesp, 2009. p. 256-257.

FRASER, Nancy. Fortunas del feminismo. Madrid: Traficantes de Sueños, 2015.

FREIRE, Paulo. A educação na cidade. 5. ed. São Paulo: Cortez, 2001.

. Política e educação. 2. ed., São Paulo: Cortez, 1995. Disponível em:

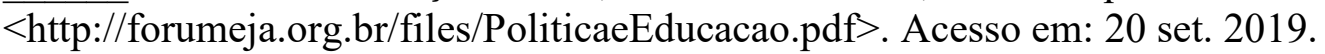

FUHRMANN, Leonardo. Doria tira recursos de CEUs e UPAs para construir creches e pagar hospitais. Folha de S. Paulo, São Paulo, 07 jun. 2017. Disponível em: $<$ https://www.nossasaopaulo.org.br/2017/06/07/doria-tira-recurso-de-ceus-e-upas-paraconstruir-creches-e-pagar-hospitais/>. Acesso em: 12 out. 2017.

GARCIA, Teise de Oliveira Guaranha. A organização do trabalho na escola e a participação dos educandos. Educação: teoria e prática, Rio Claro, v. 14, n. 26, p. 67-93, jan./jun. 2006. Disponível em:

$<$ http://www.educadores.diaadia.pr.gov.br/arquivos/File/2010/artigos_teses/2010/Pedago gia/aparticip alunosgestao.pdf>. Acesso em: 21 set. 2019

eise de Oliveira Guaranha; CORREA, Bianca Cristina. Desafios à democratização da gestão escolar e a atuação dos professores na escola pública. Retratos da Escola, v. 3, p. 225-236, 2009.

GOBBI, Márcia Aparecida. (2016). Tecendo por trás dos panos. pró-posições. v. 6, n. 2, p. 87-88. Disponível em:

$<$ https://periodicos.sbu.unicamp.br/ojs/index.php/proposic/article/view/8644272>. Acesso em: 26 out. 2019.

GOHN, Maria da Glória. Empoderamento e participação da comunidade em políticas sociais. In: Revista Saúde e Sociedade. v. 13, n. 2, 2004.

GOLDENBERG, Mirian. A invenção de uma bela velhice: em busca de uma vida com mais liberdade e felicidade. Revista Brasileira de Geriatra e Gerentologia. 2018. v. 21, n. 5, set./out., Rio de Janeiro, 2018. Disponível em:

$<$ http://www.scielo.br/scielo.php?script=sci_arttext\&pid=S1809-

98232018000500511\&lng=en\&nrm=iso\&tlng=pt $>$. Acesso em: 22 ago. 2019.

HADDAD, Fernando. Um tempo novo para São Paulo. Plano de Governo - Haddad Prefeito 2012. São Paulo, 2012. Disponível em: <https://bit.ly/2s8S2g0>. Acesso em: 24 jul. 2019.

CIDADE DE SÃO PAULO. Programa de Metas 2019-2020. 2018. Disponível em: $<$ http://programademetas.prefeitura.sp.gov.br/assets/up/Programa\%20Metas\%2020192020 texto.pdf $>$. Acesso em 12 de out. de 2019.

HIRATA, Helena; KERGOAT, Danièle. Novas configurações da divisão sexual do trabalho. Cadernos de pesquisa, v. 37, n. 132, p. 595-609, 2007. São Paulo: Fundação Carlos Chagas. 
HIRATA, Helena et al. (Org.). Dicionário crítico do feminismo. São Paulo: Unesp, 2009.

. Gênero, classe e raça: interseccionalidade e consubstancialidade das relações sociais. Tempo Social, v. 26, n. 1, junho 2014, p. 61-73.

HOOKS, bell. Erguer a voz: pensar como feminista, pensar como negra. São Paulo: Elefante, 2019.

JANNUZZI, Paulo Martino. Indicadores sociais no Brasil: conceitos, fonte de dados e aplicações. Campinas: Alínea, 2009.

JUSTINIANO, Henrique Macedo. O Centro Educacional Unificado como um fator de centralidade da periferia. 2014. 89 f. Monografia (Especialização) - Curso de Geografia, Educação, Instituto Federal de Educação Ciência e Tecnologia de São Paulo, São Paulo, 2014. Disponível em: <https://bit.ly/396PsI7>. Acesso em: 23 dez. 2019.

LAGES, Ronaldo. O CEU virou um inferno: 14 obras da Rede CEU estão paradas em SP. 32XSP, São Paulo, 13 ago. 2018. Disponível em: <https://32xsp.org.br/especial/ceuobras-paradas-sp>. Acesso em: 12 out. 2019.

LUCHMANN, Lígia Helena Hahn; ALMEIDA, Carla; GIMENES, Éder Rodrigo. Gênero e representação política nos Conselhos Gestores no Brasil. Dados, Rio de Janeiro, v. 59, n. 3, p. 789-822, Sept. 2016. Disponível em:

$<$ http://www.scielo.br/scielo.php?script=sci_arttext\&pid=S0011-

$52582016000300789 \& \operatorname{lng}=$ en\&nrm=iso $>$. Acesso em: 18 out. 2019. Doi:

http://dx.doi.org/10.1590/00115258201692.

LUIZA HEILBORN, Maria; RODRIGUES, Carla. Gênero: breve história de um conceito. Aprender - Caderno de Filosofia e Psicologia da Educação, [S.1.], n. 20, dez. 2018. ISSN 2359-246X. Disponível em:

$<$ http://periodicos2.uesb.br/index.php/aprender/article/view/4547>. Acesso em: 14 ago. 2019. Doi: https://doi.org/10.22481/aprender.v0i20.4547.

MELO, Hildete Pereira de; CONSIDERA, Claudio Monteiro; DI SABBATO, Alberto. Os afazeres domésticos contam. Economia e Sociedade, v. 16, n. 3, p. 435-454, Campinas: Universidade Estadual de Campinas, Dec. 2007. Disponível em: $<$ http://www.scielo.br/scielo.php?script=sci_arttext\&pid=S010406182007000300006\&lng=en\&nrm=iso $>$. Acesso em: 19 out. 2019. Doi: http://dx.doi.org/10.1590/S0104-06182007000300006.

NOGUEIRA, Vera Lúcia. Mulheres adultas das camadas populares: a especificidade da condição feminina no processo da busca de escolarização. In: III SEMANA DA PÓSGRADUAÇÃO DA UFMG, 2002, Belo Horizonte. Anais da III Semana da PósGraduação da UFMG, 2002.

ONU MULHERES. Princípios de empoderamento das mulheres, publicado pela Itaipu Binacional, da ONU Mulheres e Pacto Global das Nações Unidas, 2010. Disponível 
em: $<$ http://www.onumulheres.org.br/wp-

content/uploads/2016/04/cartilha_WEPs_2016.pdf>. Acesso em: 18 set. 2019.

PACHECO, Reinaldo Tadeu Bosco. O espetáculo da educação: os Centros

Educacionais Unificados do Município de São Paulo como espaços públicos de lazer. 2009. 280f. Tese (Doutorado em Educação na área de Concentração Estado, Sociedade e Educação). Faculdade de Educação da Universidade de São Paulo. Disponível em: http://www.teses.usp.br/teses/disponiveis/48/48134/tde-09092009-163829/pt-br.php. Acesso em: 03 out. 2019.

PADILHA, Paulo Roberto (Org.). Educação com qualidade social: a experiência dos CEUs de São Paulo. São Paulo: Instituto Paulo Freire, 2004. 192 p.

PARTIDO SOCIAL DEMOCRÁTICO. Obras dos novos CEUs estão paradas ou em ritmo lento, 2016. Disponível em: $<$ https://psd-sp.org.br/saopaulo/obras-dos-novos-ceusestao-paradas-ou-em-ritmo-lento/>. Acesso em: 16 ago. 2018

PEDRO, Simão. II Fórum Mundial de Educação Profissional e Tecnológica é lançado na Comissão de Educação e Cultura. Simão Pedro, 2011. Disponível em:

$<$ http://www.simaopedro.com.br/ii-forum-mundial-de-educacao-profissional-etecnologica-e-lancado-na-comissao-de-educacao-e-cultura/.> Acesso em: 21 dez. 2019

PISCITELLI, Adriana. Gênero: a história de um conceito. In. ALMEIDA, Heloísa Buarque de; SZWAKI, José. Diferenças, igualdade. São Paulo: Berlendis \& Vertecchia, 2009. p. 116-148.

PRADO, Adélia. Poesia reunida. São Paulo: Siciliano: 1999.

RODRIGUES, Daniela do Nascimento. Centro Educacional Unificado: o processo de criação de um projeto educacional na cidade de São Paulo (2001-2004). 2018. 175 f. Dissertação (Mestrado) - Educação, Faculdade de Educação, Pontifícia Universidade Católica de São Paulo, PUC/SP, São Paulo, 2018. Disponível em:

$<$ https://tede2.pucsp.br/handle/handle/21559>. Acesso em: 06 set. 2019.

ROGERIO, Rosa Maria de Freitas. Possibilidades e limites para uma coordenação compartilhada do trabalho pedagógico no CEU. 2015. 204 fls. Tese (Doutorado em Educação) - Faculdade de Educação, Universidade de São Paulo, São Paulo, 2015.

ROSEMBERG, Fúlvia. Subordinação de gênero e alfabetização no Brasil. Idéias. São Paulo: FDE, n. 19, p. 125-48, 1993.

SAFFIOTI, Heleieth Iara Bongiovani; FERRANTE, Vera Lúcia Silveira Botta. Da casa para a "rua": a caminhada das mulheres boias-frias. Perspectivas, São Paulo, v. 9, n. 10, p. 93-118, 1986/87.

SAFFIOTI, Heleieth Iara Bongiovani. A mulher na sociedade de classes: mito e realidade. Petrópolis: Vozes, 1976.

SALDAÑA, Paulo. CEUs só saem se chegar dinheiro de privatizações, diz secretário de Doria. Folha de S. Paulo, São Paulo, 27 jan. 2018. Disponível em: 
$<$ https://www1.folha.uol.com.br/educacao/2018/01/1953773-ceus-so-saem-se-chegardinheiro-de-privatizacoes-diz-secretario-de-doria.shtml>. Acesso em: 12 out. 2019.

SALDANHA, Paulo. Gestão Covas vai retomar obras paralisadas de 12 CEUs. Agora, São Paulo, 03 out. 2018. Nas ruas. Disponível em:

$<$ https://agora.folha.uol.com.br/saopaulo/2018/10/1982849-gestao-covas-vai-retomarobras-paralisadas-de-12-ceus.shtml>.Acesso em: 10 out. 2019.

SANCHES, Ydeliz Coelho de. SOUZA. A gestão do Centro Educacional Unificado (CEU) da cidade de São Paulo. 2014. 336 f. Tese (Doutorado) - Curso de Educação, Faculdade de Educação, Universidade de São Paulo, São Paulo, 2014. Disponível em: $<$ https://www.teses.usp.br/teses/disponiveis/48/48134/tde-02102014155242/publico/YDELIZ_COELHO_DE_SOUZA_SANCHES.pdf $>$. Acesso em: 21 set. 2019.

SÃO PAULO (Município). Decreto n ${ }^{\circ} 57.478$, de 28 de novembro de 2016. Aprova o Regimento Padrão dos Centros Educacionais Unificados - CEUs, vinculados à Secretaria Municipal de Educação.

SÃO PAULO (Município). Decreto no 42.832, de 6 de fevereiro de 2003. Cria os Centros Educacionais Unificados que especifica.

SÃO PAULO (MUNICÍPIO). Decreto 45.559, de 30 de novembro de 2004. Aprova o Regimento Padrão dos Centros Educacionais Unificados - CEUs.

SÃO PAULO (MUNICÍPIO). Decreto 46.701, de 01 de dezembro de 2005. Delega competência ao secretário municipal de educação para aprovar o regimento padrão dos Centros Educacionais Unificados - CEUs.

SÃO PAULO (MUNICÍPIO). Decreto 50.738, de 15 de julho de 2009. Regulamenta a lei $\mathrm{n}^{\mathrm{o}} 14.662$, de 3 de janeiro de 2008, que dispõe sobre a criação dos conselhos gestores dos Centros Educacionais Unificados - CEUs.

SÃO PAULO (MUNICÍPIO). Decreto 54.823, de 07 de fevereiro de 2014. Dispõe sobre a gestão compartilhada dos Centros Educacionais Unificados - CEUs entre as Secretarias Municipais de Educação, de Cultura e de Esportes, Lazer e Recreação.

SÃO PAULO (MUNICÍPIO). Lei 16.050, de 31 de julho de 2014. Aprova a política de Desenvolvimento Urbano e o Plano Diretor Estratégico do Município de São Paulo e revoga a Lei $n^{\circ} 13.430 / 2002$.

SÃO PAULO (Município). Lei Municipal n 13.245, de 26 de dezembro de 2001. Define as despesas consideradas no cômputo do percentual das receitas destinadas à educação.

SÃO PAULO (MUNICÍPIO). Lei 14.662, de 03 de janeiro de 2008. Dispõe sobre a criação dos Conselhos Gestores dos Centros de Educação Unificados - CEUs da Rede Direta Municipal, instalada no município de São Paulo e dá outras providências. 
SÃO PAULO (MUNICÍPIO). Lei 16.050, de 31 de julho de 2014. Aprova a política de Desenvolvimento Urbano e o Plano Diretor Estratégico do Município de São Paulo e revoga a Lei $\mathrm{n}^{\mathrm{o}} 13.430 / 2002$.

SÃO PAULO (MUNICÍPIO). Portaria 7.720, de 20 de novembro de 2016. Institui a Política de Transparência ativa e Dados Abertos e o Plano Anual de Transparência ativa e Dados Abertos no âmbito da Secretaria Municipal de Educação e dá outras providências.

SÃO PAULO (MUNICÍPIO). Territórios CEU: rede de equipamentos e espaços públicos Secretaria Municipal de Desenvolvimento Urbano - SMDU. São Paulo: SMDU, 2016. 204 p. Disponível em: <http://gestaourbana.prefeitura.sp.gov.br/wpcontent/uploads/2016/12/GEST\%C3\%83Oterritorio_ceu_rede_de_equipamentos_e_espacos_publicos.pdf $>$. Acesso em: 24 ago. 2018 .

SÃO PAULO (MUNICÍPIO). Portaria 2.212, de 26 de março de 2003. Institui a função de gestor geral dos centros educacionais unificados - CEU's e estabelece critérios e procedimentos para sua ocupação.

SÃO PAULO (MUNICÍPIO). Portaria 4.672, de 05 de dezembro de 2006. Aprova o Regimento Padrão dos Centros Educacionais Unificados - CEUs.

SÃO PAULO (MUNICÍPIO). Portaria 7.356, de 23 de dezembro de 2005. Aprova o Regimento Padrão dos Centros Educacionais Unificados - CEUs.

SÃO PAULO (MUNICÍPIO). Decreto 45.559, de 30 de novembro de 2004. Regimento Padrão dos CEUs.

SÃO PAULO (MUNICÍPIO). Portaria 5.542, de 03 de dezembro de 2004. Dispõe sobre o processo eletivo do Conselho Gestor nos Centros Educacionais Unificados - CEUs.

SECRETARIA DE GOVERNO. Balanço de Gestão. Secretaria de Governo da Prefeitura Municipal de São Paulo, São Paulo, 2004. Disponível em:

$<$ https://www.prefeitura.sp.gov.br/cidade/secretarias/upload/arquivos/secretarias/governo/ BalancoGestao.pdf>. Acesso em: 21 dez. 2019

SME/PMSP (Secretaria Municipal de Educação/Prefeitura Municipal de São Paulo). Construindo o Projeto Político Pedagógico (Projeto Educacional). São Paulo: Instituto Paulo Freire, 2005.

SARTI, Cynthia Andersen. O feminismo brasileiro desde os anos 1970: revisitando uma trajetória. Revista Estudos Feministas, v. 12, n. 2, p. 35-50, 2004.

SCOTT, Joan Wallach. Gênero: uma categoria útil de análise histórica. Educação e realidade, Porto Alegre, v. 20, n. 2, jul./dez., 1995, p. 71-99.

. História das mulheres. In. BURKE, Peter. (Org.) A escrita da história: novas perspectivas. São Paulo: Unesp, 1992. 
SILVA, Maria Luciana Brandão. Uma pedagogia da experiência do encontro bordada nas trocas: Associação de Mulheres do Bairro Bethânia. Minas Gerais. 2010. 270f. Tese (Doutorado em Educação) - Universidade Federal de Minas Gerais, Minas Gerais, 2010.

SILVA, Roberto da; Padilha, Paulo Roberto. Educação com qualidade social: a experiência dos CEUs de São Paulo. São Paulo: Cortez/IPF, 2004.

SORJ, Bila. Políticas sociais, participação comunitária e a desprofissionalização do care. Cadernos Pagu, n. 46, p. 107-128, Campinas, 1 jun. 2016.

SOUZA, Ricardo de. A educação social em espaços de experimentação pedagógica: as potencialidades dos CEUs. 2010. 301 f. Dissertação (Mestrado) - Curso de Educação, Faculdade de Educação, Universidade de São Paulo, São Paulo, 2010. Disponível em: $<$ http://www.teses.usp.br/teses/disponiveis/48/48134/tde-16092010-135019/pt-br.php>. Acesso em: 27 set. 2019.

STROMQUIST, Nelly. La busqueda del empoderamento: em qué puede contribuir el campo de la educación. In: LEÓN, Magdalena (Org). Poder y empoderamiento de las mujeres. Bogotá: MT Editores, 1997.

TATAGIBA, Luciana. Conselhos gestores de políticas públicas e democracia participativa: aprofundando o debate. In: FUKS, M.; PERISSINOTTO, R. M.; SOUZA, N. R. (Eds.). Democracia e participação: os conselhos gestores do Paraná. Curitiba: Editora UFPR, 2004. p. 246.

VIANNA, Cláudia Pereira. O sonho que nos move: mães de alunos do Movimento Estadual Pró-educação na luta pela melhoria do ensino público. Dissertação (Mestrado em Educação). São Paulo: Pontifícia Universidade Católica de São Paulo, 1992.

VIEIRA, Victor. Uma gestão inacabada: promessas e realizações de Fernando Haddad. O Estado de S. Paulo, São Paulo, 03 ago. 2015. Disponível em:

$<$ https://infograficos.estadao.com.br/cidades/uma-gestao-inacabada/educacao.php $>$. Acesso em: 17 set. 2019. 


\section{APÊNDICE 1}

Relação de CEUs por localização, região e data de inauguração

\begin{tabular}{|c|c|c|c|c|}
\hline & CEU & Bairro & Região & Inauguração \\
\hline 1 & Jambeiro & Guaianazes & Leste & $01 / 08 / 2003$ \\
\hline 2 & Rosa da China & Sapopemba & Leste & $10 / 08 / 2003$ \\
\hline 3 & Perus & Vila Malvina & Norte & $25 / 08 / 2003$ \\
\hline 4 & Cidade Dutra & Interlagos & Sul & $30 / 08 / 2003$ \\
\hline 5 & Aricanduva & Vila Aricanduva & Leste & $07 / 09 / 2003$ \\
\hline 6 & Parque Veredas & Chácara Dona Olivia & Leste & $15 / 09 / 2003$ \\
\hline 7 & Butantã & Jardim Esmeralda & Oeste & $27 / 09 / 2003$ \\
\hline 8 & Vila Atlântica & Jaraguá & Norte & $12 / 10 / 2003$ \\
\hline 9 & Meninos & São João Clímaco & Sul & $28 / 10 / 2003$ \\
\hline 10 & São Mateus & Parque Boa Esperança & Leste & $08 / 11 / 2003$ \\
\hline 11 & Pêra Marmelo & Jardim Santa Lucrécia & Norte & $13 / 11 / 2003$ \\
\hline 12 & Inácio Monteiro & COHAB Inácio Monteiro & Leste & $21 / 11 / 2003$ \\
\hline 13 & Vila Curuçá & Jardim Miragaia & Leste & $28 / 11 / 2003$ \\
\hline 14 & Parque São Carlos & Jardim Parque São Carlos & Leste & $03 / 12 / 2003$ \\
\hline 15 & Alvarenga & Pedreira & Sul & $09 / 12 / 2003$ \\
\hline 16 & Navegantes & Parque Residencial Cocaia & Sul & $12 / 12 / 2003$ \\
\hline 17 & Três Lagos & Barro Branco & Sul & $12 / 12 / 2003$ \\
\hline 18 & São Rafael & Jardim Rio Claro & Leste & $28 / 03 / 2004$ \\
\hline 19 & Campo Limpo & Pirajussara & Sul & $17 / 04 / 2004$ \\
\hline 20 & Paz & Jardim Paraná & Norte & $15 / 05 / 2004$ \\
\hline 21 & Casa Blanca & Vila das Belezas & Sul & $27 / 06 / 2004$ \\
\hline 22 & Vila Rubi & Grajaú & Sul & $29 / 09 / 2007$ \\
\hline 23 & Jaçana & Jardim Guapira & Norte & $06 / 10 / 2007$ \\
\hline 24 & Água Azul & COHAB Cidade Tiradentes & Leste & $20 / 10 / 2007$ \\
\hline 25 & Azul da Cor do Mar & Cidade AE Carvalho & Leste & $27 / 10 / 2007$ \\
\hline 26 & Quinta do Sol & Cangaíba & Leste & $19 / 04 / 2008$ \\
\hline 27 & Lajeado & Lajeado & Sul & $17 / 05 / 2008$ \\
\hline 28 & Guarapiranga & Jardim Ângela & Sul & $24 / 05 / 2008$ \\
\hline 29 & Vila do Sol & Jardim Ângela & Sul & $31 / 05 / 2008$ \\
\hline 30 & Feitiço da Vila & Capão Redondo & Sul & $07 / 06 / 2008$ \\
\hline 31 & Jardim Paulistano & Brasilândia & Norte & $15 / 06 / 2008$ \\
\hline 32 & Cantos do Amanhecer & Jardim Eledy & Sul & $22 / 06 / 2008$ \\
\hline 33 & Sapopemba & Jardim Sapopemba & Leste & $28 / 06 / 2008$ \\
\hline 34 & Três Pontes & Jardim Célia & Leste & $31 / 08 / 2008$ \\
\hline 35 & Caminho do Mar & Jabaquara & Sul & $12 / 10 / 2008$ \\
\hline 36 & Tiquatira & Penha & Leste & $15 / 11 / 2008$ \\
\hline
\end{tabular}




\begin{tabular}{|l|l|c|c|c|}
\hline 37 & Alto Alegre & Iguatemi & Sul & $29 / 11 / 2008$ \\
\hline 38 & Parelheiros & Jardim Novo Parelheiros & Sul & $06 / 12 / 2008$ \\
\hline 39 & Paraisópolis & Jardim Parque Morumbi & Sul & $13 / 12 / 2008$ \\
\hline 40 & Capão Redondo & Capão Redondo & Sul & $14 / 12 / 2008$ \\
\hline 41 & Jardim Anhanguera & Jardim Anhanguera & Norte & $20 / 12 / 2008$ \\
\hline 42 & Parque Bristol & Parque Bristol & Sul & $21 / 03 / 2009$ \\
\hline 43 & Jaguaré & Jaguaré & Oeste & $28 / 11 / 2009$ \\
\hline 44 & Uirapuru & Jardim Paulo VI & Oeste & 2009 \\
\hline 45 & Formosa & Vila Formosa & Leste & $28 / 08 / 2010$ \\
\hline 46 & Heliópolis & São João Clímaco & Sul & $29 / 04 / 2015$ \\
\hline
\end{tabular}


APÊNDICE 2

Infraestrutura dos CEUs

\begin{tabular}{|c|c|c|c|c|c|c|c|c|c|c|c|c|}
\hline \multicolumn{13}{|c|}{ Infraestrutura } \\
\hline \multicolumn{2}{|r|}{ CEU } & \multirow[t]{2}{*}{ Unidades escolares } & \multicolumn{10}{|c|}{ Quantidade } \\
\hline Qtd/espaços & & & Teatro & Camarim & Biblioteca & Telecentro & Piscina & Quadras & $\begin{array}{l}\text { Campo } \\
\text { society/ } \\
\text { futebol }\end{array}$ & $\begin{array}{c}\text { Pista } \\
\text { de } \\
\text { skate }\end{array}$ & $\begin{array}{l}\text { Campo } \\
\text { de areia }\end{array}$ & $\begin{array}{c}\text { Sala de } \\
\text { dança/ginástica/artes } \\
\text { marciais }\end{array}$ \\
\hline 1 & Jambeiro & CEI; EMEI; EMEF; ETEC e POLO UAB & 1 & 4 & 1 & 1 & 3 & 3 & 2 & 1 & - & 2 \\
\hline 2 & Rosa da China & CEI; EMEI; EMEF e POLO UAB & 1 & 4 & 1 & 1 & 3 & 2 & - & 1 & - & 3 \\
\hline 3 & Perus & CEI; EMEI e EMEF & 1 & 4 & 1 & - & 3 & 1 & - & 1 & - & 1 \\
\hline 4 & Cidade Dutra & CEI; EMEI; EMEF e POLO UAB & 1 & - & 1 & 1 & 3 & 2 & - & 1 & - & 1 \\
\hline 5 & Aricanduva & CEI; 2 EMEIs; EMEF e POLO UAB & 1 & - & 1 & 1 & 3 & 2 & - & 1 & - & 1 \\
\hline 6 & Parque Veredas & CEI; EMEI; EMEF e ETEC & 1 & 4 & 1 & - & 3 & 2 & - & 1 & - & 1 \\
\hline 7 & Butantã & CEI; EMEI; EMEF; ETEC e POLO UAB & 1 & - & 1 & 1 & 3 & 5 & - & 1 & 1 & 2 \\
\hline 8 & Vila Atlântica & CEI; EMEI; EMEF e POLO UAB & 1 & 4 & 1 & 1 & 3 & 1 & - & 1 & - & 2 \\
\hline 9 & Meninos & CEI; EMEI; EMEF e POLO UAB & 1 & 4 & 1 & 1 & 3 & 2 & 2 & 1 & - & 1 \\
\hline 10 & São Mateus & CEI; EMEI e EMEF & 1 & 4 & 1 & - & 3 & 2 & 1 & 1 & - & - \\
\hline 11 & Pêra Marmelo & CEI; EMEI; EMEF e POLO UAB & 1 & 4 & 1 & 1 & 3 & 1 & - & 1 & - & 1 \\
\hline 12 & Inácio Monteiro & CEI; EMEI; EMEF e ETEC & 1 & - & 1 & 1 & 3 & 2 & - & 1 & - & 2 \\
\hline 13 & Vila Curuçá & CEI; EMEI; EMEF e POLO UAB & 1 & 4 & 1 & 1 & 3 & 2 & - & 1 & - & 1 \\
\hline 14 & Parque São Carlos & CEI; EMEI; EMEF; ETEC e POLO UAB & 1 & 4 & 1 & 1 & 3 & 2 & - & - & - & 1 \\
\hline 15 & Alvarenga & CEI; EMEI; EMEF; ETEC e POLO UAB & 1 & - & 1 & 1 & 3 & 2 & - & 1 & - & 1 \\
\hline 16 & Navegantes & CEI; EMEI; EMEF e POLO UAB & 1 & 4 & 1 & 1 & 3 & 1 & - & 1 & - & 1 \\
\hline 17 & Três Lagos & CEI; EMEI; EMEF e ETEC & 1 & 4 & 1 & - & 3 & 1 & - & 1 & - & 1 \\
\hline 18 & São Rafael & CEI; EMEI e EMEF & 1 & 4 & 1 & - & 3 & 2 & - & 1 & - & 1 \\
\hline 19 & Campo Limpo & CEI; EMEI; EMEF e POLO UAB & 1 & 4 & 1 & 1 & 3 & 3 & 1 & 1 & - & 3 \\
\hline 20 & Paz & CEI; EMEI e EMEF & 1 & 4 & 1 & - & 3 & 1 & - & - & - & 1 \\
\hline 21 & Casa Blanca & CEI; EMEI; EMEF e POLO UAB & 1 & 4 & 1 & 1 & 3 & 3 & - & 1 & - & 1 \\
\hline 22 & Vila Rubi & CEI; EMEI; EMEF e ETEC & 1 & 4 & 1 & 1 & 3 & 3 & - & - & - & 2 \\
\hline
\end{tabular}




\begin{tabular}{|c|c|c|c|c|c|c|c|c|c|c|c|c|}
\hline \multicolumn{13}{|c|}{ Infraestrutura } \\
\hline \multicolumn{2}{|r|}{ CEU } & \multirow[t]{2}{*}{ Unidades escolares } & \multicolumn{10}{|c|}{ Quantidade } \\
\hline Qtd/espaços & & & Teatro & Camarim & Biblioteca & Telecentro & Piscina & Quadras & $\begin{array}{l}\text { Campo } \\
\text { society/ } \\
\text { futebol } \\
\end{array}$ & $\begin{array}{c}\text { Pista } \\
\text { de } \\
\text { skate }\end{array}$ & $\begin{array}{l}\text { Campo } \\
\text { de areia }\end{array}$ & $\begin{array}{c}\text { Sala de } \\
\text { dança/ginástica/artes } \\
\text { marciais }\end{array}$ \\
\hline 23 & Jaçanã & CEI; EMEI; EMEF; ETEC e POLO UAB & 1 & - & 1 & 1 & 3 & 3 & - & - & - & 1 \\
\hline 24 & Água Azul & CEI; EMEI; EMEF e POLO UAB & 1 & - & 1 & 1 & 3 & 2 & 1 & - & 1 & 1 \\
\hline 25 & Azul da Cor do Mar & CEI; EMEI; EMEF; ETEC e POLO UAB & 1 & - & 1 & 1 & 3 & 2 & - & - & - & 4 \\
\hline 26 & Quinta do Sol & CEI; EMEI; EMEF e POLO UAB & 1 & 4 & 1 & 1 & 3 & 1 & - & - & - & 2 \\
\hline 27 & Lajeado & CEI; EMEI; EMEF e ETEC & 1 & - & 1 & 1 & 3 & 2 & - & - & - & 1 \\
\hline 28 & Guarapiranga & CEI; EMEI e EMEF & 1 & - & 1 & 1 & 3 & 2 & - & - & - & 3 \\
\hline 29 & Vila do Sol & CEI; EMEI; EMEF; ETEC e POLO UAB & 1 & - & 1 & 1 & 3 & 2 & - & - & 1 & 1 \\
\hline 30 & Feitiço da Vila & CEI; EMEI e EMEF & 1 & - & 1 & - & 3 & 2 & - & - & - & 1 \\
\hline 31 & Jardim Paulistano & CEI; EMEI; EMEF e POLO UAB & - & - & 1 & 1 & 3 & 2 & 2 & - & - & - \\
\hline 32 & Cantos do Amanhecer & CEI; EMEI; EMEF e ETEC & 1 & - & 1 & - & 3 & 2 & - & - & - & - \\
\hline 33 & Sapopemba & CEI; EMEI; EMEF e ETEC & 1 & 2 & 1 & 1 & 3 & 2 & - & - & - & - \\
\hline 34 & Três Pontes & CEI; EMEI; EMEF e ETEC & 1 & 2 & 1 & 1 & 3 & 2 & - & - & - & 2 \\
\hline 35 & Caminho do Mar & CEI; EMEI; EMEF e ETEC & 1 & - & 1 & 1 & 3 & 2 & - & - & - & 4 \\
\hline 36 & Tiquatira & CEI; EMEI e EMEF & 1 & - & 1 & - & 3 & 2 & - & - & - & 1 \\
\hline 37 & Alto Alegre & CEI; EMEI; EMEF e ETEC & 1 & 2 & 1 & 1 & 3 & 2 & - & - & - & - \\
\hline 38 & Parelheiros & CEI; EMEI; EMEF; ETEC e POLO UAB & - & - & 1 & 1 & 3 & 2 & 1 & - & 1 & 2 \\
\hline 39 & Paraisópolis & CEI; EMEI; EMEF e POLO UAB & 1 & 2 & 1 & 1 & 3 & 3 & - & - & - & 1 \\
\hline 40 & Capão Redondo & CEI; EMEI; EMEF e ETEC & 1 & - & 1 & 1 & 3 & 2 & - & - & - & - \\
\hline 41 & Jardim Anhanguera & CEI; EMEI; EMEF e ETEC & 1 & 2 & 1 & 1 & 3 & 3 & - & - & - & 2 \\
\hline 42 & Parque Bristol & CEI; EMEI; EMEF; ETEC e POLO UAB & 1 & - & 1 & 1 & 3 & 2 & - & - & - & 1 \\
\hline 43 & Jaguaré & CEI; EMEI; EMEF e ETEC & 1 & - & 1 & 1 & 3 & 1 & - & - & - & 1 \\
\hline 44 & Uirapuru & CEI; EMEI e EMEF & 1 & 2 & 1 & 1 & 3 & 2 & - & - & - & 2 \\
\hline 45 & Formosa & CEI; EMEI e EMEF e UNICEU & 1 & - & 1 & 1 & 3 & 2 & - & - & - & - \\
\hline 46 & Heliópolis & CEI; EMEI; EMEF; ETEC e UNICEU & - & - & 1 & - & - & 1 & - & - & - & 1 \\
\hline
\end{tabular}




\section{APÊNDICE 3 \\ TERMO DE CONSENTIMENTO LIVRE E ESCLARECIDO}

Prezada

Você está sendo convidada para participar, como voluntária, da pesquisa de mestrado que tem como objetivo compreender a participação das mulheres no Conselho Gestor do Centro Educacional Unificado (CEU) XXX, localizado no distrito de XXXX, que tem como pesquisadora responsável Cristiane Bibiano Silva, aluna da Faculdade de Educação da Universidade de São Paulo, orientada pela Profa. Dra. Cláudia Pereira Vianna. A mestranda

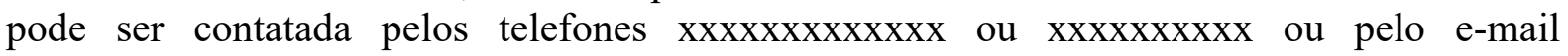
crisbibiano@usp.br, onde você poderá tirar suas dúvidas sobre o projeto e sua participação nele, agora ou em qualquer momento.

Sua participação não é obrigatória. Se você concordar em participar, concederá entrevista, que será gravada para fins de pesquisa. Tudo o que for dito na entrevista será confidencial e anônimo. As informações reunidas serão utilizadas unicamente nesta pesquisa e em seus desdobramentos. A pesquisadora responsável se compromete a tornar públicos nos meios acadêmicos e científicos os resultados obtidos, seguindo as diretrizes éticas da pesquisa, assegurando, assim, a privacidade, sem qualquer identificação de indivíduos participantes.

Caso você concorde em participar desta pesquisa, assine ao final deste documento, que possui duas vias, sendo uma delas sua e a outra da pesquisadora responsável da pesquisa.

$\mathrm{Eu}$, portadora do documento de identidade fui informada dos objetivos do estudo de maneira clara e detalhada e esclareci minhas dúvidas. Sei que a qualquer momento poderei solicitar novas informações e modificar minha decisão de participar se assim o desejar.

Declaro que concordo em participar desse estudo. Recebi uma cópia deste termo de consentimento livre e esclarecido.

São Paulo, de de 2018.

Assinatura da Entrevistada 



\section{APÊNDICE 4}

\section{ROTEIRO DA ENTREVISTA INDIVIDUAL}

FALA DE ABORDAGEM: Este será um momento para conversarmos sobre algumas questões em torno da participação da mulher no Conselho Gestor do Centro Educacional Unificado (CEU). O propósito é conversar com você a partir do seu olhar sobre sua experiência de participação no Conselho Gestor. Não irei julgar suas respostas e não há certo e/ou errado. Quero deixar claro que não se trata de uma avaliação, mas sim entender como você construiu essa trajetória e os desafios que você passou e que imagina que outras mulheres possam passar. Reafirmo que sua identidade não será divulgada de forma alguma e que a gravação é para que eu possa retomar nossa conversa em um outro momento.

\section{FOCO CENTRAL}

Como as desigualdades de gênero e outras tencionam (positiva e/ou negativamente) na participação das mulheres em um Conselho Gestor do CEU.

*Conte-me antes de entrar para o conselho gestor do CEU? O que fazia?

\begin{tabular}{|c|c|c|c|c|c|c|}
\hline $\begin{array}{c}\text { Como se tornou } \\
\text { conselheira? } \\
\text { Como foi sua } \\
\text { trajetória de participação? } \\
\text { (sofreu influência } \\
\text { de algum familiar ou } \\
\text { conhecido para começar na } \\
\text { militância; outros } \\
\text { movimentos; antes do } \\
\text { conselho gestor; motivações; } \\
\text { obstáculos iniciais e atuais). } \\
\text { Você almeja entrar } \\
\text { para a política profissional? }\end{array}$ & $\begin{array}{c}\text { Como você vê a } \\
\text { participação das mulheres } \\
\text { em esferas políticas como } \\
\text { o CG? } \\
\text { Tem diferença em } \\
\text { relação aos homens? } \\
\text { Quais? Como } \\
\text { avalia? } \\
\text { Tem } \\
\text { semelhanças? Quais? } \\
\text { Como avalia? } \\
\text { Você vê desafios } \\
\text { nessa participação } \\
\text { feminina? (Voz no CG; } \\
\text { respeito; dificuldades; } \\
\text { obstáculos; discriminação; } \\
\text { interrupção) }\end{array}$ & $\begin{array}{c}\text { Como é seu dia a } \\
\text { dia? } \\
\text { E como inclui nele } \\
\text { suas participações coletivas e } \\
\text { no CG? } \\
\text { Quanto tempo, em } \\
\text { média, no seu dia a dia, gasta } \\
\text { para se deslocar na cidade } \\
\text { para realizar a atividade } \\
\text { principal, considerando a ida } \\
\text { e a volta? } \\
\text { Qual meio de } \\
\text { transporte utiliza? } \\
\text { Quais os principais } \\
\text { problemas desse meio de } \\
\text { transporte que influência seu } \\
\text { cotidiano? }\end{array}$ & $\begin{array}{c}\text { Quando } \\
\text { conselheira, como } \\
\text { concilia as tarefas } \\
\text { domésticas, cuidado } \\
\text { com família, trabalho } \\
\text { etc., com o trabalho } \\
\text { no CG? } \\
\text { As pessoas } \\
\text { do seu domicílio } \\
\text { participam dos } \\
\text { afazeres domésticos? } \\
\text { Elas } \\
\text { frequentam o CEU? }\end{array}$ & $\begin{array}{l}\text { Você tem } \\
\text { tempo para lazer? } \\
\text { (Se sim, o } \\
\text { que faz? } \\
\text { Utiliza o } \\
\text { CEU? } \\
\text { (qual a } \\
\text { frequência de lazer } \\
\text { e os obstáculos para } \\
\text { a realização). }\end{array}$ & $\begin{array}{c}\text { IN OFF } \\
\text { Você acha } \\
\text { necessário algum } \\
\text { tipo de formação ou } \\
\text { capacitação para } \\
\text { atuar no CG? } \\
\text { Já teve? } \\
\text { Se } \\
\text { houvesse a } \\
\text { oportunidade você } \\
\text { participaria? }\end{array}$ & $\begin{array}{c}\text { IN OFF } \\
\text { Você acha que } \\
\text { sua participação no CG } \\
\text { trouxe mudanças na } \\
\text { sua vida? } \\
\text { E no CEU, fez } \\
\text { diferença? } \\
\text { Pode fazer } \\
\text { diferença na condução } \\
\text { das políticas públicas } \\
\text { da comunidade? } \\
\text { Recomendaria } \\
\text { para outras mulheres a } \\
\text { participação no CG? } \\
\text { Por quê? }\end{array}$ \\
\hline
\end{tabular}

*QUESTÕES PARALELAS

- Quais os principais problemas sociais existentes na localidade onde reside que impactam na sua vida cotidiana?

- O que é "política" para você? 


\section{APÊNDICE 5 \\ QUESTIONÁRIO INDIVIDUAL}

\section{Atributos pessoais das mulheres participantes do Conselho Gestor}

1. Nome (fictício)

2. Sexo

3. Idade

4. Cor/raça

5. Estado civil

6. Religião

7. Escolaridade

8. Ocupação

9. Naturalidade

10. Bairro onde reside:

11. Quanto tempo reside no bairro?

\section{Família, condição familiar e rendimento}

12. Quantas pessoas residem em seu domicílio?

13. Você tem filhos? Sim ( ) Não ( )

14. Em caso afirmativo, quantos filhos/as e quais as idades:

15. Há pessoas menores de 10 anos que moram no seu domicílio?

16. Se sim, quantas?

17. Caso a resposta à pergunta anterior tenha sido afirmativa, quem é a responsável pelo cuidado dos menores de 10 anos na sua casa?

18. Qual o grau de parentesco com essas pessoas menores de 10 anos?

19. Caso o(s) menor(es) de 10 anos frequente(m) creche e/ou educação infantil, qual o total de horas diárias que permanecem no estabelecimento?

20. Há pessoas idosas ou deficientes que moram no seu domicílio?

21. Se sim, quantas?

22. Caso a resposta à pergunta anterior tenha sido afirmativa, quem é responsável pelo cuidado dos idosos e/ou pessoas com deficiência na sua casa?

23. Qual o grau de parentesco com essas pessoas idosas e/ou com deficiência?

24. Outras pessoas de sua moradia frequentam o CEU? Qual o grau de parentesco? 
25. Quem é responsável pelas tarefas domésticas na sua casa?

26. Quantas horas você dedica normalmente por semana aos afazeres domésticos?

27. Os homens na sua casa (caso existam) também realizam afazerem domésticos?

28. Os menores de 10 anos de seu domicílio frequentam a creche e/ou a educação infantil? Se sim, onde?

29. A empresa onde você trabalhava adotava trabalho flexível e/ou a possibilidade de trabalhar em casa?

30. Quando conselheira, realizava trabalho fora do domicílio?

31. Qual a sua situação profissional quando conselheira do CEU, do trabalho principal?

32. Qual sua ocupação ou função, do trabalho principal quando conselheira?

33. Com que frequência realizava esse trabalho?

34. Você contribui para o orçamento de seu grupo familiar ou seus rendimentos são somente para você? Caso contribua, qual é a porcentagem?

35. Quem você considera chefe em sua família? Por quê?

36. Recebia benefícios de programas de transferência de renda, quando conselheira?

37. Se sim, qual(is) o(s) programa(s)?

38. Qual a situação legal de sua moradia?

39. Quais destes serviços atendem sua moradia? (marque um x naquele que a usuária tem acesso em sua casa)
a) Telefone fixo
b) Internet
c) Rede pública de água
d) Rede pública de energia elétrica
e) Rede de esgoto
f) Coleta de lixo
g) Iluminação pública
h) Guias e sarjetas
i) Pavimentação
j) Outros 